\title{
Radical Decarboxylative Carbometalation of Benzoic Acids: A Solution to Aromatic Decarboxylative Fluorination
}

Peng Xu, Priscila López-Rojas, Tobias Ritter*

\author{
Max-Planck-Institut für Kohlenforschung \\ Kaiser-Wilhelm-Platz 1, D-45470 Mülheim an der Ruhr, Germany \\ *E-mail: ritter@kofo.mpg.de
}




\section{TABLE OF CONTENTS}

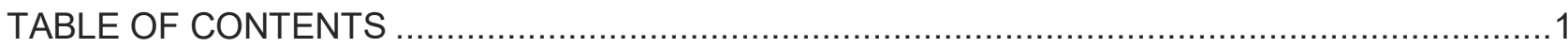

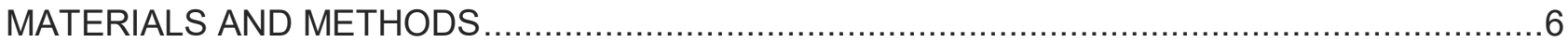

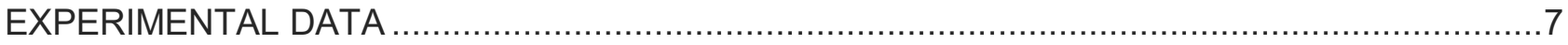

General procedure for aromatic decarboxylative fluorination .........................................................

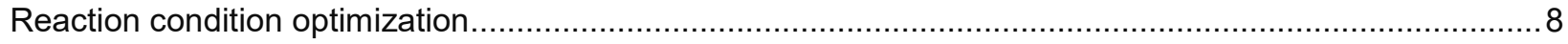

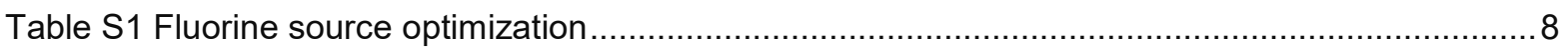

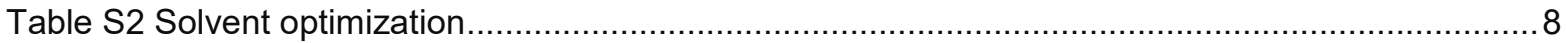

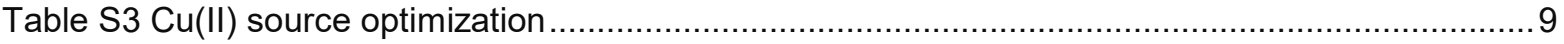

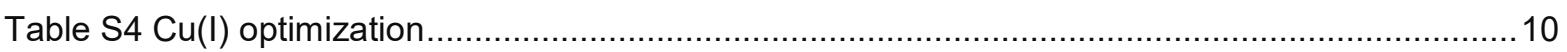

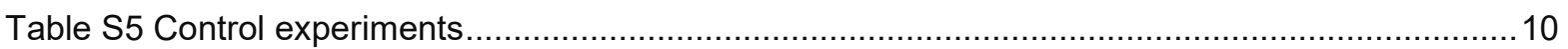

Table S6 Effects of reaction temperature on the reaction yield ...................................................11

Photo-induced LMCT-enabled aromatic decarboxylative fluorination ................................................. 12

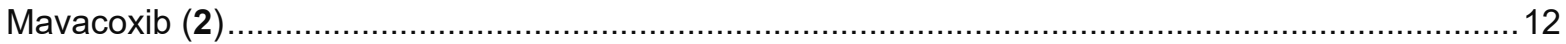

1,4-Difluorobenzene (4), fluorobenzene (4a) and 4-fluorophenyl 4-fluorobenzoate (4b) .................13

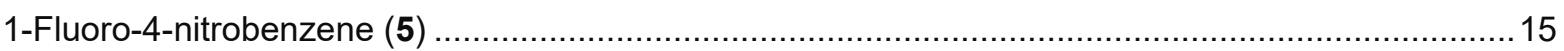

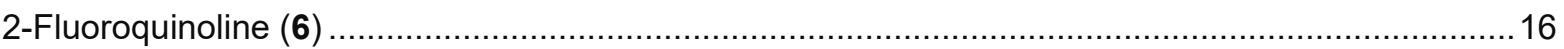

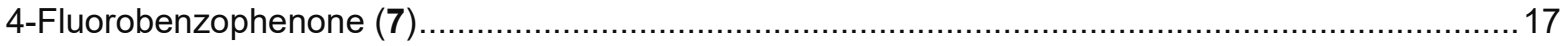

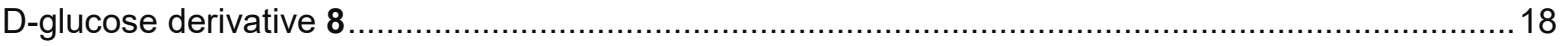

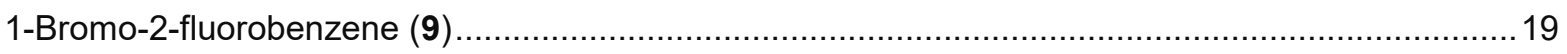

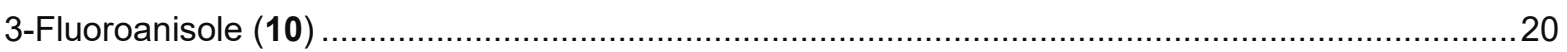

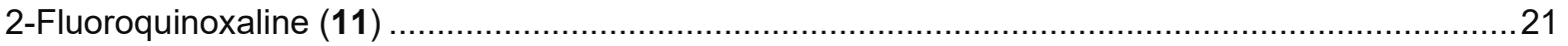

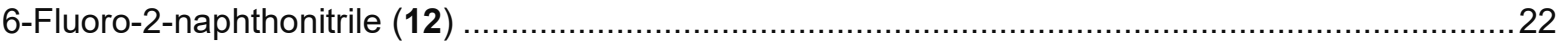

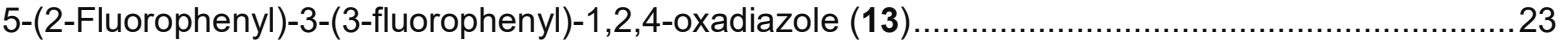

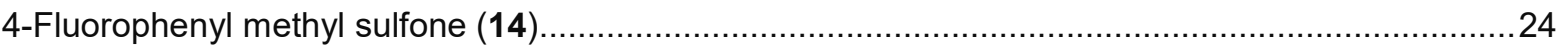

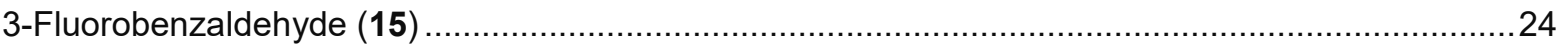

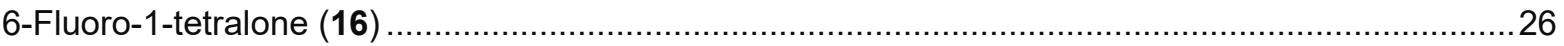

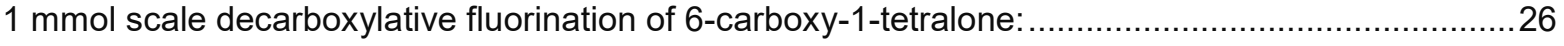

2,2'-(5-Fluoro-1,3-phenylene)bis(2-methylpropanenitrile) (17) .................................................27

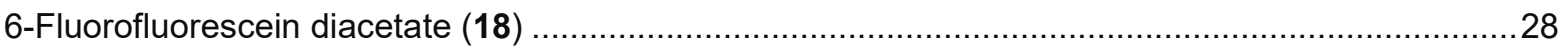

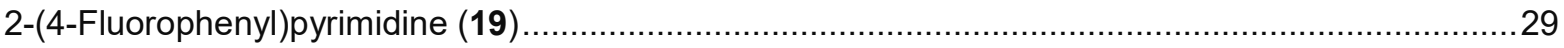

4-Fluorobenzamide (20)

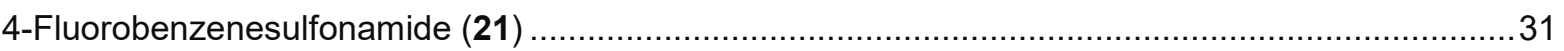

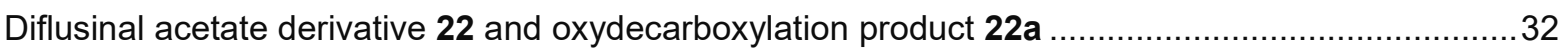

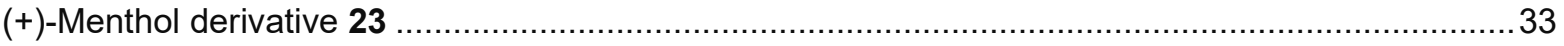

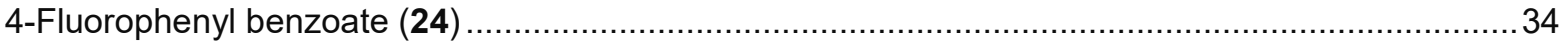




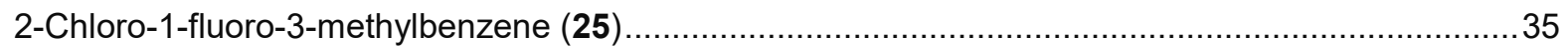

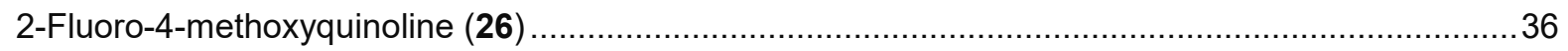

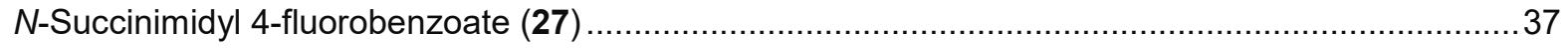

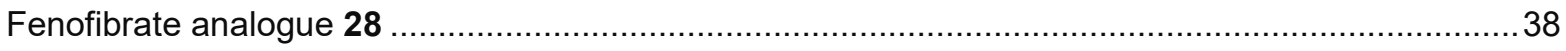

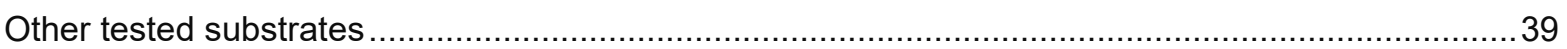

Reaction performed outside of a glovebox by using Schlenk techniques........................................39

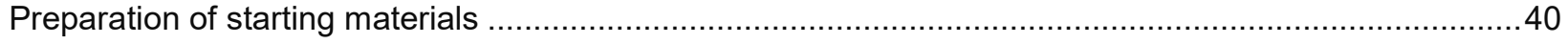

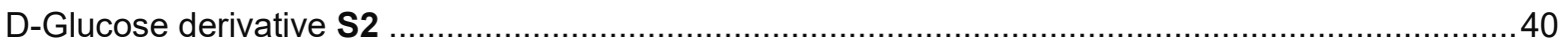

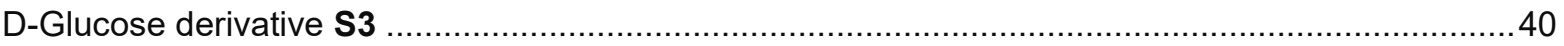

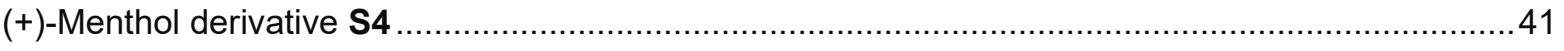

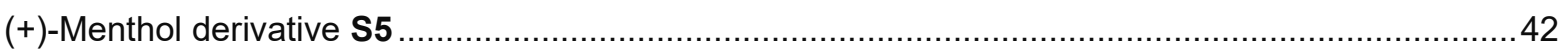

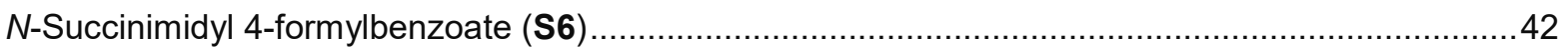

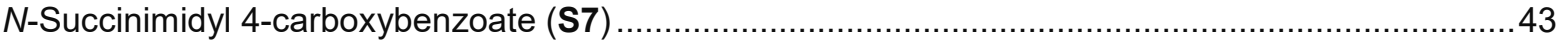

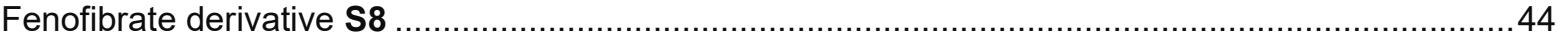

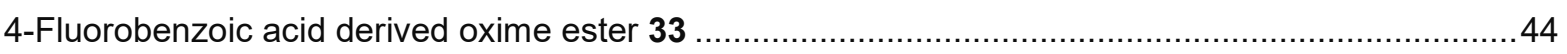

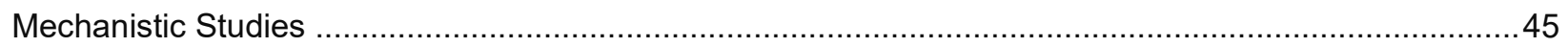

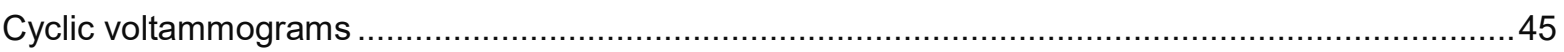

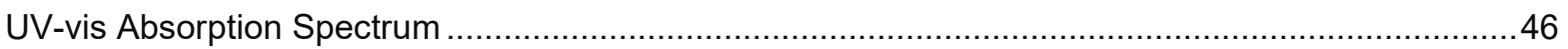

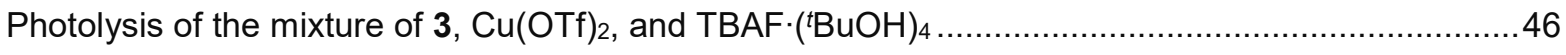

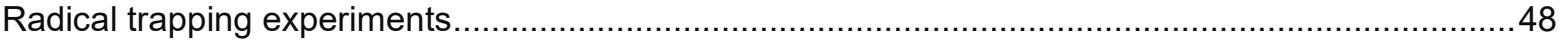

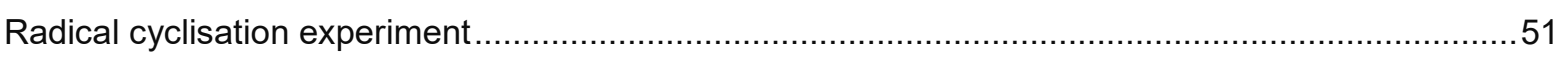

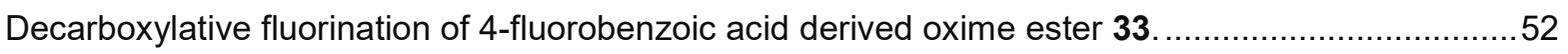

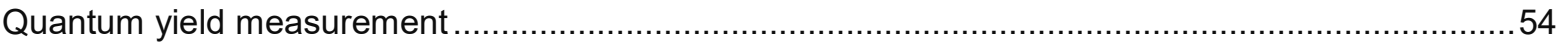

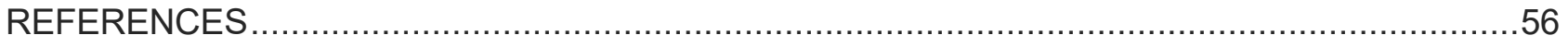

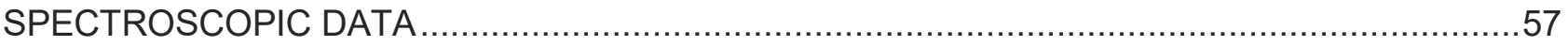

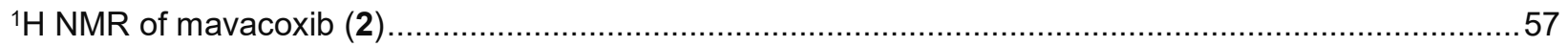

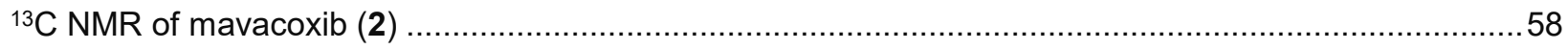

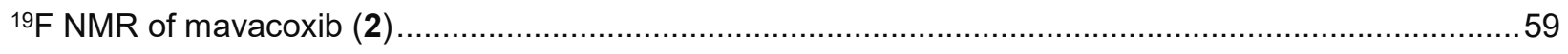

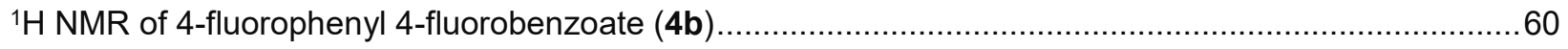

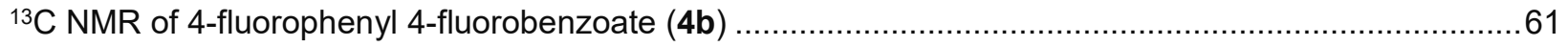

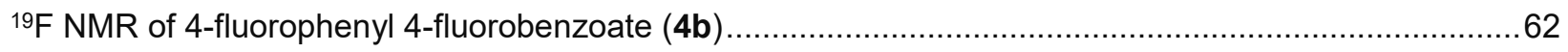

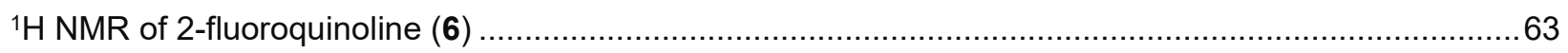

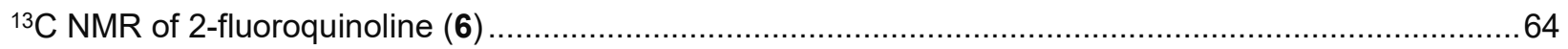


${ }^{19} \mathrm{~F}$ NMR of 2-fluoroquinoline (6)

${ }^{1} \mathrm{H}$ NMR of 4-fluorobenzophenone (7)

${ }^{13} \mathrm{C}$ NMR of 4-fluorobenzophenone (7) 67

${ }^{19} \mathrm{~F}$ NMR of 4-fluorobenzophenone (7) 68

${ }^{1} \mathrm{H}$ NMR of D-glucose derivative 8 69

${ }^{13} \mathrm{C}$ NMR of D-glucose derivative 8 . .70

${ }^{19} \mathrm{~F}$ NMR of D-glucose derivative 8 .71

${ }^{1} \mathrm{H}$ NMR of 6-fluoro-2-naphthonitrile (12) .72

${ }^{13} \mathrm{C}$ NMR of 6-fluoro-2-naphthonitrile (12) .73

${ }^{19}$ F NMR of 6-fluoro-2-naphthonitrile (12). .74

${ }^{1} \mathrm{H}$ NMR of 5-(2-fluorophenyl)-3-(3-fluorophenyl)-1,2,4-oxadiazole (13) ..............................................75

${ }^{13} \mathrm{C}$ NMR of 5-(2-fluorophenyl)-3-(3-fluorophenyl)-1,2,4-oxadiazole (13)............................................76

${ }^{19} \mathrm{~F}$ NMR of 5-(2-fluorophenyl)-3-(3-fluorophenyl)-1,2,4-oxadiazole (13) ...............................................77

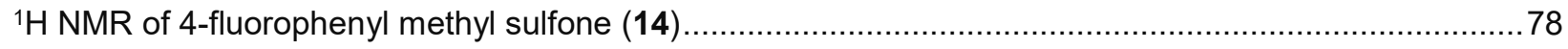

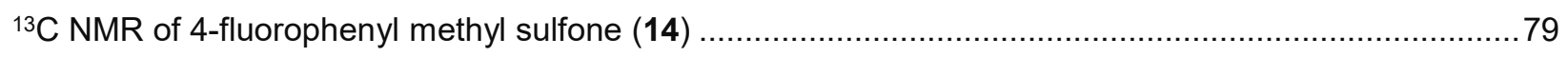

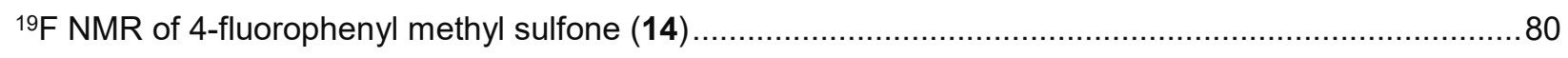

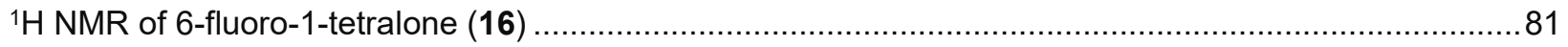

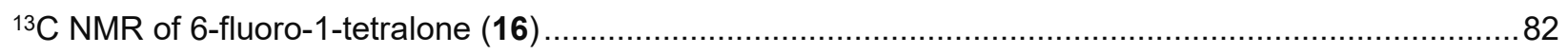

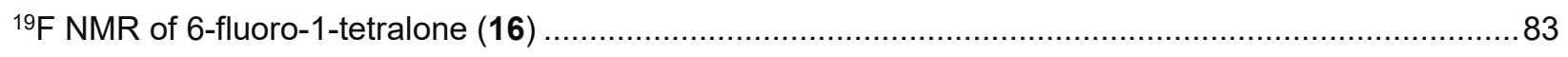

${ }^{1} \mathrm{H}$ NMR of 2,2'-(5-fluoro-1,3-phenylene)bis(2-methylpropanenitrile) (17) ......................................... 84

${ }^{13} \mathrm{C}$ NMR of 2,2'-(5-fluoro-1,3-phenylene)bis(2-methylpropanenitrile) (17) ......................................... 85

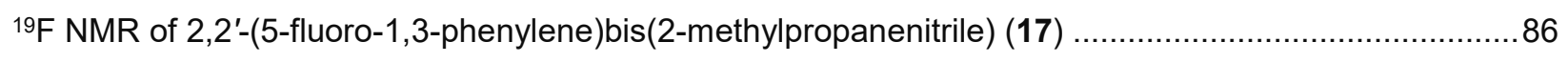

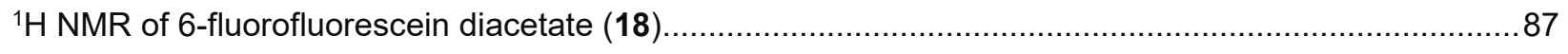

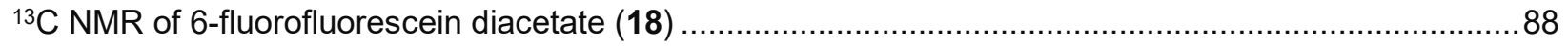

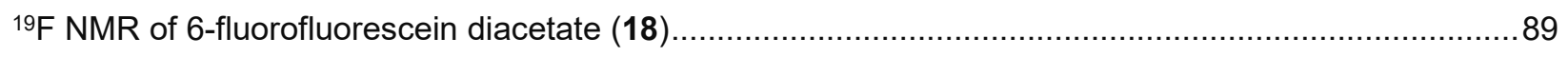

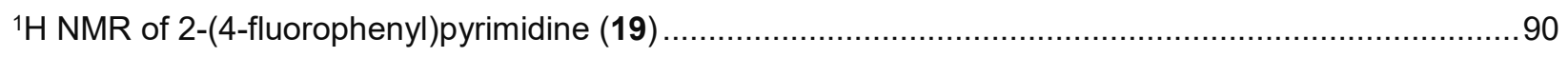

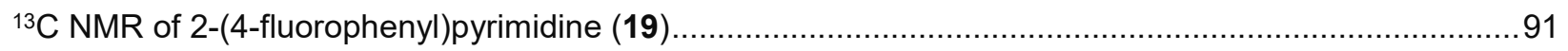

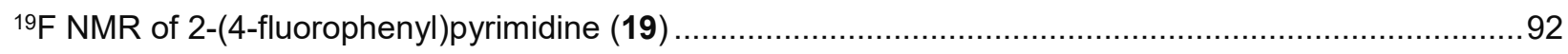

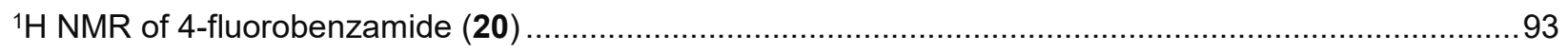




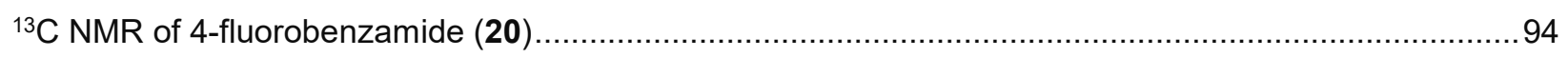

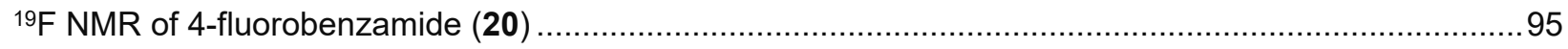

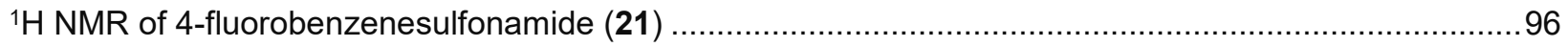

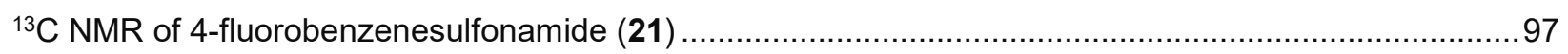

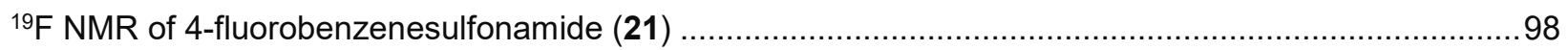

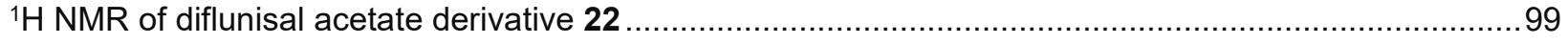

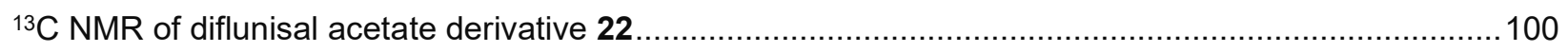

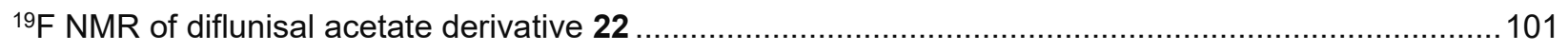

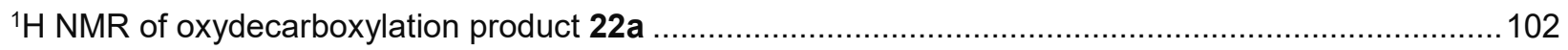

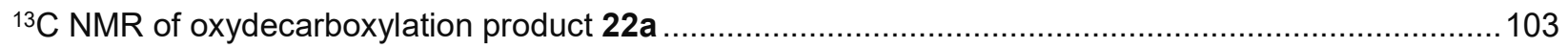

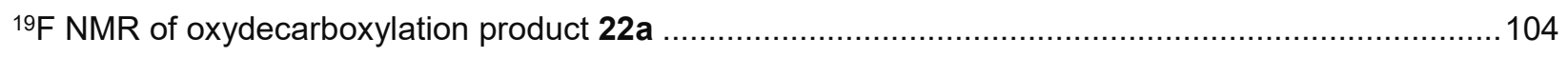

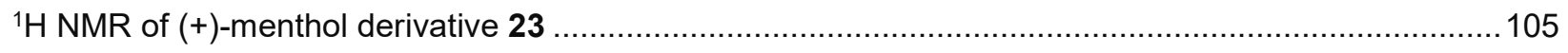

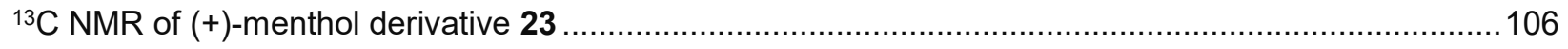

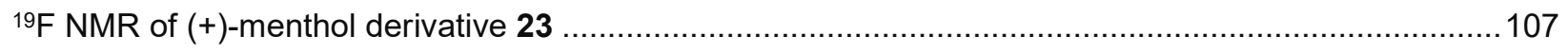

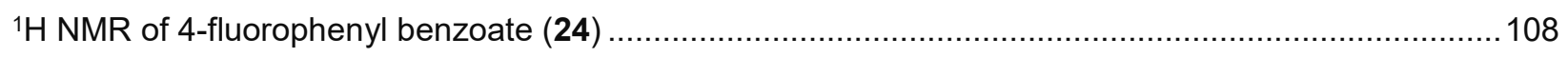

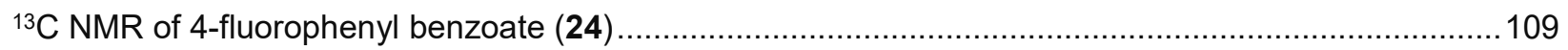

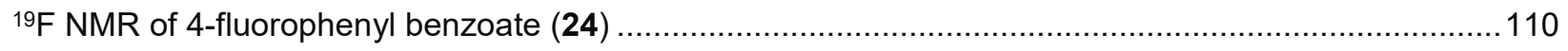

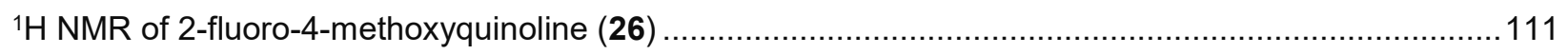

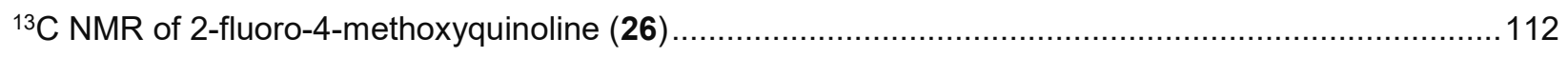

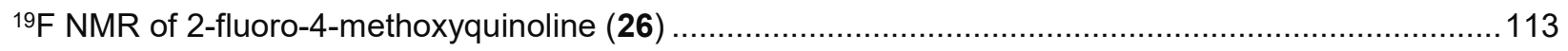

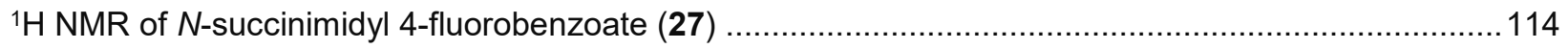

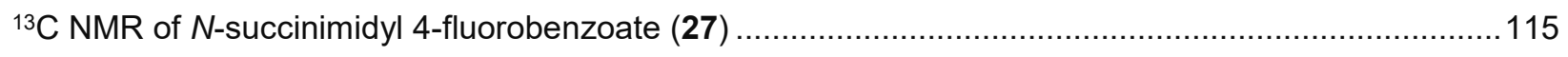

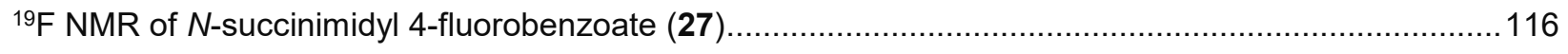

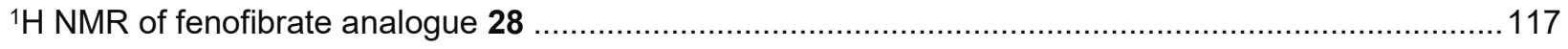

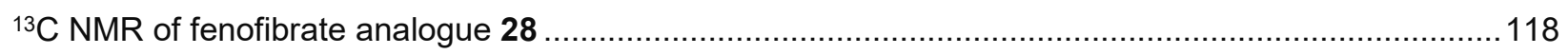

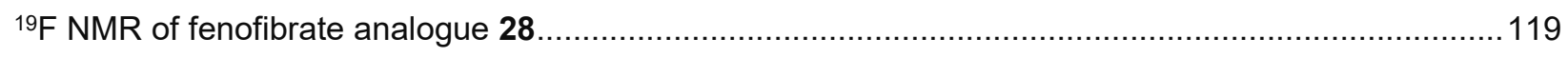

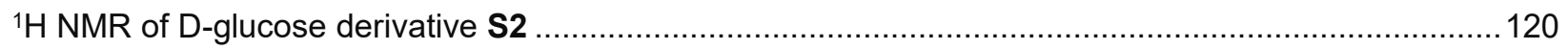

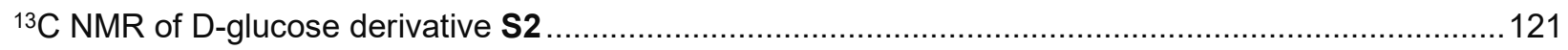

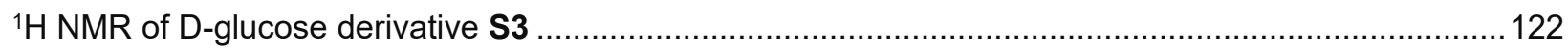




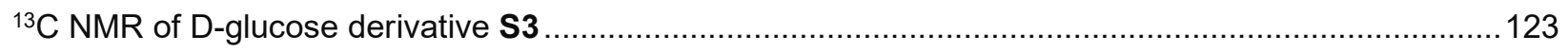

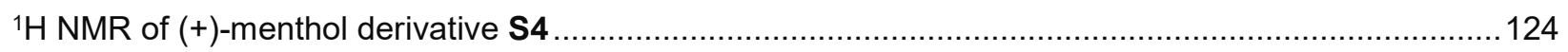

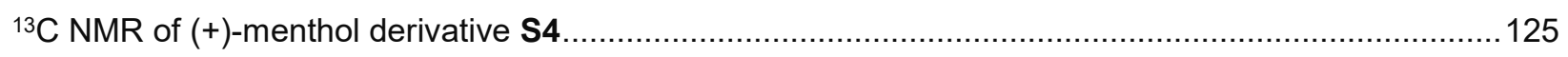

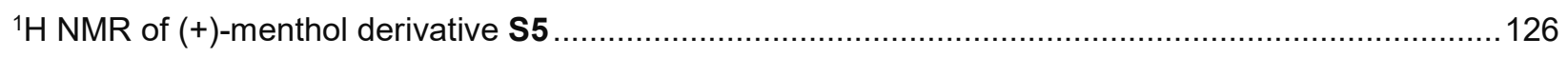

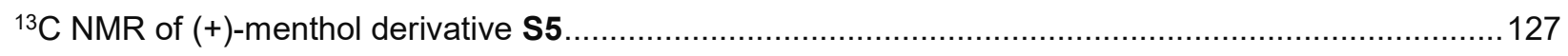

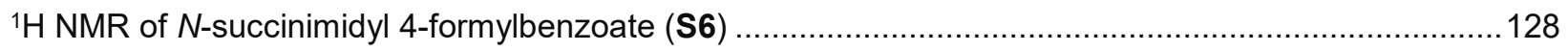

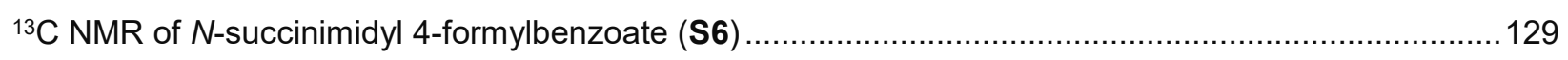

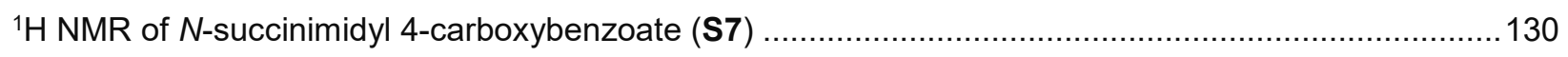

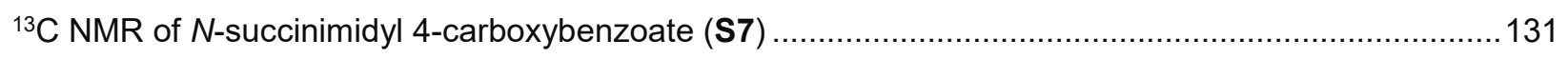

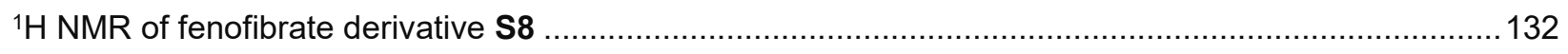

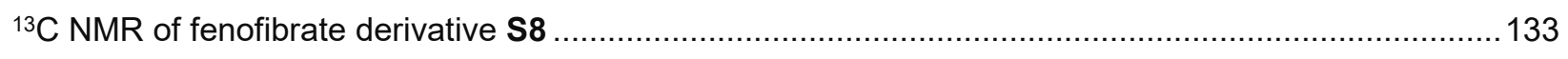

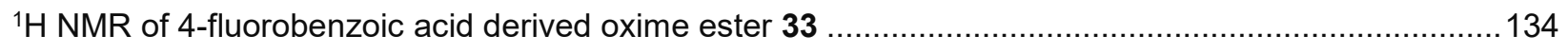

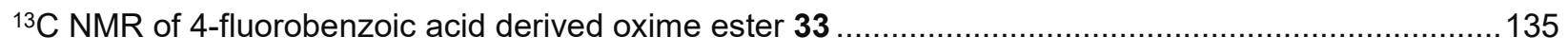

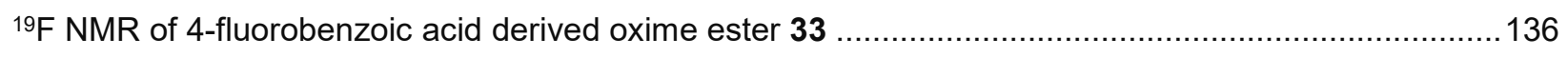

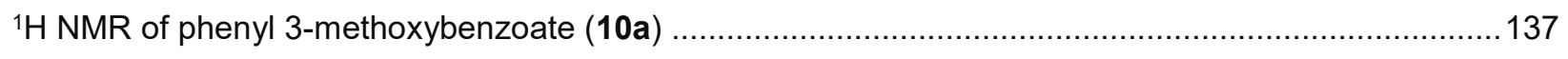

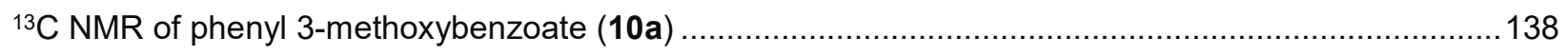

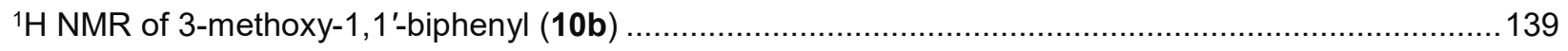

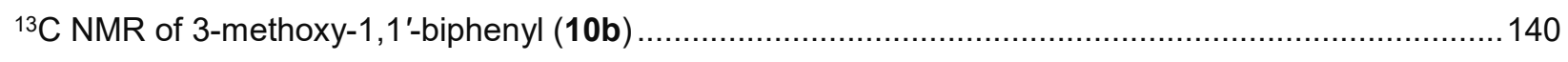

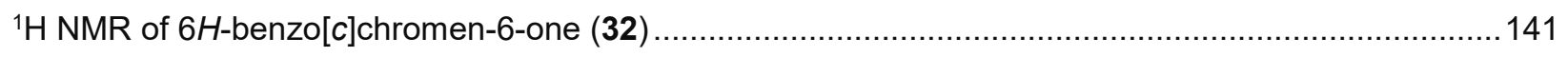

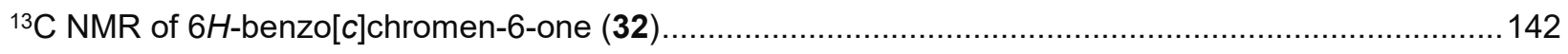




\section{MATERIALS AND METHODS}

All air- and moisture-insensitive reactions were carried out under an ambient atmosphere and monitored by thin-layer chromatography (TLC). All air- and moisture-sensitive manipulations were performed using standard Schlenk and glove-box techniques under an atmosphere of nitrogen. Concentration under reduced pressure was performed by rotary evaporation at $25-40^{\circ} \mathrm{C}$ at an appropriate pressure, unless otherwise stated. Purified compounds were further dried under high vacuum (0.008-0.5 Torr). Yields refer to purified and spectroscopically pure compounds, unless otherwise stated.

\section{Solvents}

Acetonitrile (99.9+\%, Extra Dry, AcroSeal ${ }^{\mathrm{TM}}$, ACROS Organics ${ }^{\mathrm{TM}}$ ) was purchased from Fisher Scientific $\mathrm{GmbH}$. Anhydrous DCM, THF, and toluene were obtained from Phoenix Solvent Drying Systems. All deuterated solvents were purchased from Euriso-Top.

\section{Chromatography}

Thin layer chromatography (TLC) was performed using EMD TLC silica gel 60 F254 plates pre-coated with 250 $\mu \mathrm{m}$ thickness silica gel and visualized by fluorescence quenching under UV light or phosphomolybdic acid stain. Preparative HPLC separation was executed on Shimadzu Prominence Preparative HPLC system. Preparative TLC was performed using pre-coated TLC plates SIL G-100 UV 254 (Layer: $1.00 \mathrm{~mm}$ silica gel 60 with fluorescent indicator $\mathrm{UV}_{254}$ ).

\section{Spectroscopy and Instruments}

NMR spectra were recorded on a Bruker Ascend ${ }^{\mathrm{TM}} 500$ spectrometer operating at $500 \mathrm{MHz}, 471 \mathrm{MHz}$, and $126 \mathrm{MHz}$, for ${ }^{1} \mathrm{H},{ }^{19} \mathrm{~F}$, and ${ }^{13} \mathrm{C}$ acquisitions, respectively; a Bruker UltraShield ${ }^{\mathrm{TM}} 300$ spectrometer operating at $300 \mathrm{MHz}, 282 \mathrm{MHz}$, and $75 \mathrm{MHz}$, for ${ }^{1} \mathrm{H},{ }^{19} \mathrm{~F}$, and ${ }^{13} \mathrm{C}$ acquisitions, respectively; or a Bruker AV600 spectrometer operating at $150 \mathrm{MHz}$ for ${ }^{13} \mathrm{C}$ acquisitions. Chemical shifts are reported in ppm with the solvent residual peak as the internal standard. For ${ }^{1} \mathrm{H}$ NMR: $\mathrm{CDCl}_{3}, \delta 7.26 ; \mathrm{CD}_{3} \mathrm{CN}, \delta 1.94 ; \mathrm{CD}_{2} \mathrm{Cl}_{2}, \delta 5.32$, acetone- $d_{6}, \delta 2.05$; $\left(\mathrm{CD}_{3}\right)_{2} \mathrm{SO}, \delta$ 2.50. For ${ }^{13} \mathrm{C} \mathrm{NMR:} \mathrm{CDCl}_{3}, \delta 77.16 ; \mathrm{CD}_{3} \mathrm{CN}, \delta 1.32 ; \mathrm{CD}_{2} \mathrm{Cl}_{2}, \delta 53.84,\left(\mathrm{CD}_{3}\right)_{2} \mathrm{SO}, \delta 39.52 .{ }^{1}$ Data is reported as follows: $\mathrm{s}=$ singlet, $\mathrm{d}=$ doublet, $\mathrm{t}=$ triplet, $\mathrm{q}=$ quartet, $\mathrm{m}=$ multiplet, $\mathrm{brs}=$ broad singlet; coupling constants in $\mathrm{Hz}$; integration.

\section{Starting materials}

All substrates and materials were used as received from commercial suppliers, unless otherwise stated. $\mathrm{Cu}(\mathrm{OTf})_{2}$ purchased from Fluorochem was dried in a $150{ }^{\circ} \mathrm{C}$ oven for 3 days and stored in a glovebox. $\mathrm{Cu}(\mathrm{MeCN})_{4} \mathrm{BF}_{4}$ was purchased from $\mathrm{TCl}$ and stored in a glovebox. TBAF. $\left({ }^{t} \mathrm{BuOH}\right)_{4}$ was prepared according to the literature ${ }^{2}$ and stored in a glovebox. Carboxycelecoxib (1) was synthesized according to the literature. ${ }^{3}$ Isopropyl 2-methyl-2-(4-(4-vinylbenzoyl)phenoxy)propanoate (S1) was prepared according to the literature. ${ }^{4}$ 


\section{EXPERIMENTAL DATA}

\section{General procedure for aromatic decarboxylative fluorination}

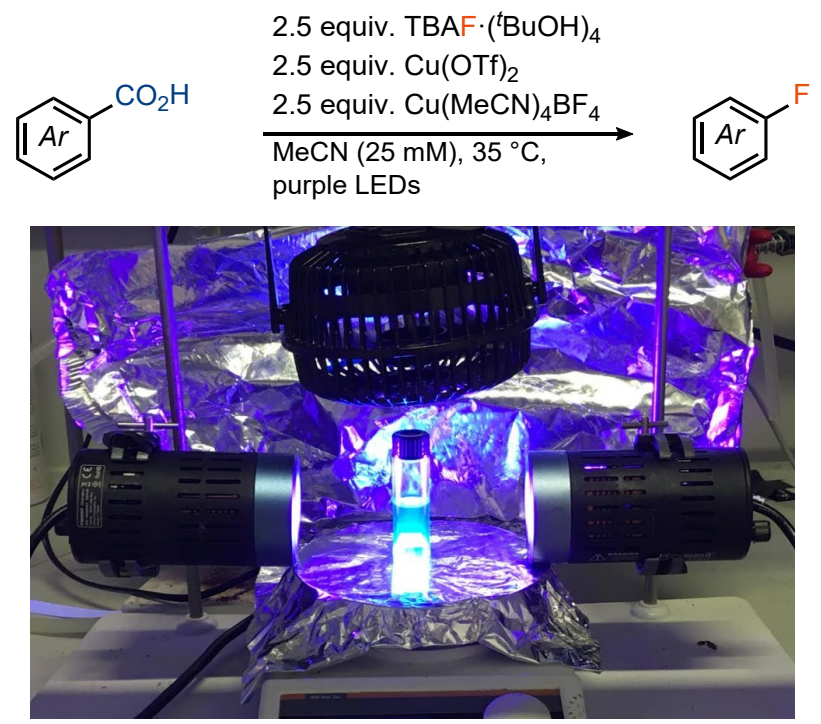

Figure S1. Photo of the irradiation setup for aromatic decarboxylative fluorination

Under nitrogen atmosphere, a $16 \mathrm{~mL}$ borosilicate vial equipped with a magnetic stir bar was charged with aryl carboxylic acid $\left(0.200 \mathrm{mmol}, 1.00\right.$ equiv.), $\mathrm{Cu}(\mathrm{OTf})_{2}$ (0.500 mmol, 2.50 equiv.), $\mathrm{Cu}(\mathrm{MeCN})_{4} \mathrm{BF}_{4}(0.500 \mathrm{mmol}$, 2.50 equiv. $)$, and TBAF·( $\left.{ }^{(B u O H}\right)_{4}(0.500 \mathrm{mmol}, 2.50$ equiv. $)$. Anhydrous $\mathrm{MeCN}(8.0 \mathrm{~mL}, \mathrm{c}=25 \mathrm{mM})$ was then added into the vial. The vial was sealed with a Teflon cap and placed $5 \mathrm{~cm}$ away from two purple LEDs (Kessil PR160-390 nm LEDs). The reaction mixture was stirred without irradiation for $30 \mathrm{~min}$ at ambient temperature and then irradiated for 6 or $24 \mathrm{~h}$ while maintaining the temperature at approximately $35^{\circ} \mathrm{C}$ through cooling with a fan. After irradiation, the reaction mixture was transferred to a $25 \mathrm{~mL}$ round-bottom flask and evaporated to dryness. The residue was dissolved in DCM $(20 \mathrm{~mL})$, transferred into a separatory funnel containing $5 \mathrm{~mL}$ saturated aqueous $\mathrm{NH}_{4} \mathrm{Cl}$ and $5 \mathrm{~mL} \mathrm{H}_{2} \mathrm{O}$, and the layers were separated. The organic layer was collected, and the aqueous layer was further extracted with DCM $(3 \times$ ca. $20 \mathrm{~mL})$. The combined organic layer was dried over $\mathrm{Na}_{2} \mathrm{SO}_{4}$, filtered, and the solvent was removed under reduced pressure. The residue was purified by chromatography on silica gel. Where necessary, further purification was accomplished by preparative HPLC or preparative TLC.

NOTE: UV light is harmful to human health, and the operator should wear UV light safety glass when setting up the reaction. For the duration of the reaction, the irradiation setup was covered with aluminium foil to shield the UV light. The reaction is moisture sensitive, the use of anhydrous $\mathrm{MeCN}$ and TBAF $\left({ }^{t} \mathrm{BuOH}\right)_{4}$ is important for the reaction. When wet MeCN was used or TBAF· $\left({ }^{t} \mathrm{BuOH}\right)_{4}$ was weighed without further drying under ambient atmosphere, the yield of the fluorodecarboxylation product is lower and the yield of the oxydecarboxylation product is higher. For simplicity, all reaction components were stored and weighed in a $\mathrm{N}_{2}$ filled glovebox, though the reactions can be performed outside of a glovebox by using Schlenk techniques to avoid moisture. 


\section{Reaction condition optimization}

Table S1 Fluorine source optimization

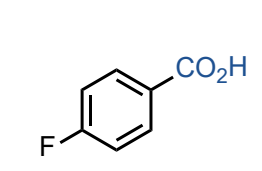

(0.05 mmol, 1.00 equiv.)
2.5 equiv. fluorine source 2.5 equiv. $\mathrm{Cu}(\mathrm{OTf})_{2}$

2.5 equiv. $\mathrm{Cu}(\mathrm{MeCN})_{4} \mathrm{BF}_{4}$ $\mathrm{MeCN}(25 \mathrm{mM}), 35^{\circ} \mathrm{C}$ purple LEDs, $6 \mathrm{~h}$

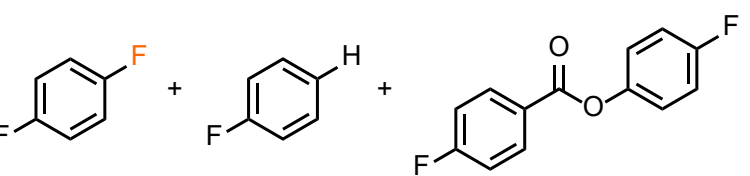

4

$4 a$

4b

\begin{tabular}{|c|c|c|c|}
\hline fluorine source & Yield $(\mathbf{4} / \mathbf{4 a} / \mathbf{4 b}, \%)^{a}$ & fluorine source & Yield $(\mathbf{4} / \mathbf{4} \mathbf{a} / \mathbf{4} \mathbf{b}, \%)^{a}$ \\
\hline TBAF·( $\left.{ }^{t} \mathrm{BuOH}\right)_{4}$ & $70 / 4 / 20$ & $\mathrm{CsF}$ & $18 / 4 / 76$ \\
\hline $1 \mathrm{M}$ TBAF in THF & $4 / 6 / 80$ & $\mathrm{NaF}$ & $9 / 4 / 36$ \\
\hline $\mathrm{TMAF} \cdot 4 \mathrm{H}_{2} \mathrm{O}$ & $11 / 4 / 84$ & $\mathrm{TBAF} \cdot 3 \mathrm{H}_{2} \mathrm{O}$ & $8 / 3 / 64$ \\
\hline TBAT & $66 / 8^{b} / 28$ & $\mathrm{KF}$ & $45 / 3 / 44$ \\
\hline TASF & $49 / 3 / 32$ & NFSI & $9 / 30 / 20$ \\
\hline TMAF & $64 / 4 / 28$ & NFPT & $23 / 6 / 56$ \\
\hline $\mathrm{Et}_{3} \mathrm{~N} \cdot 3 \mathrm{HF}^{c}$ & $7 / 4 / 84$ & Selectfluor $®$ & $14 / 24 / 20$ \\
\hline
\end{tabular}

a Yield was determined by ${ }^{19} \mathrm{~F}$ NMR using 2-fluorotoluene( 2.0 equiv.) as an internal standard.

${ }^{b}$ Under reaction condition, difluorotriphenylsilicate ion in TBAT performs fluorodesilylation to afford $4 a$ ${ }^{c} 0.83$ equiv. Et ${ }_{3} \mathrm{~N} \cdot 3 \mathrm{HF}(2.5$ equiv. $\mathrm{HF})$ was added.

Table S2 Solvent optimization

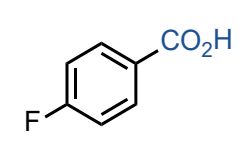

(0.05 mmol, 1.00 equiv.)

3

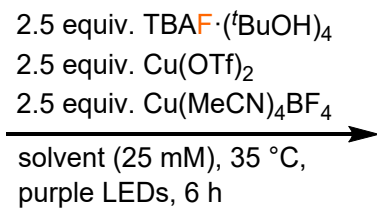

purple LEDs, $6 \mathrm{~h}$<smiles>Fc1ccc(F)cc1</smiles>

4<smiles>Fc1ccc([18F])cc1</smiles>

$+$<smiles>O=C(Oc1ccc(F)cc1)c1ccc(F)cc1</smiles>

4b

Solvent 


\begin{tabular}{cccc}
\hline MeCN & $\mathbf{7 0 / 4 / 2 0}$ & DCM & $0 / 0 / 12$ \\
DMSO & $0 / 0 / 0$ & 1,4-dioxane & $0 / 0 / 0$ \\
DMF & $0 / 0 / 0$ & toluene & $0 / 0 / 0$ \\
THF & $0 / 0 / 0$ & acetone & $0 / 0 / 0$ \\
propionitrile & $38 / 10 / 40$ & isobutyronitrile & $24 / 12 / 52$ \\
\hline
\end{tabular}

${ }^{\text {a }}{ }^{19}$ F NMR yield with 2-fluorotoluene( 2.0 equiv.) as an internal standard.

Table S3 Cu(II) source optimization

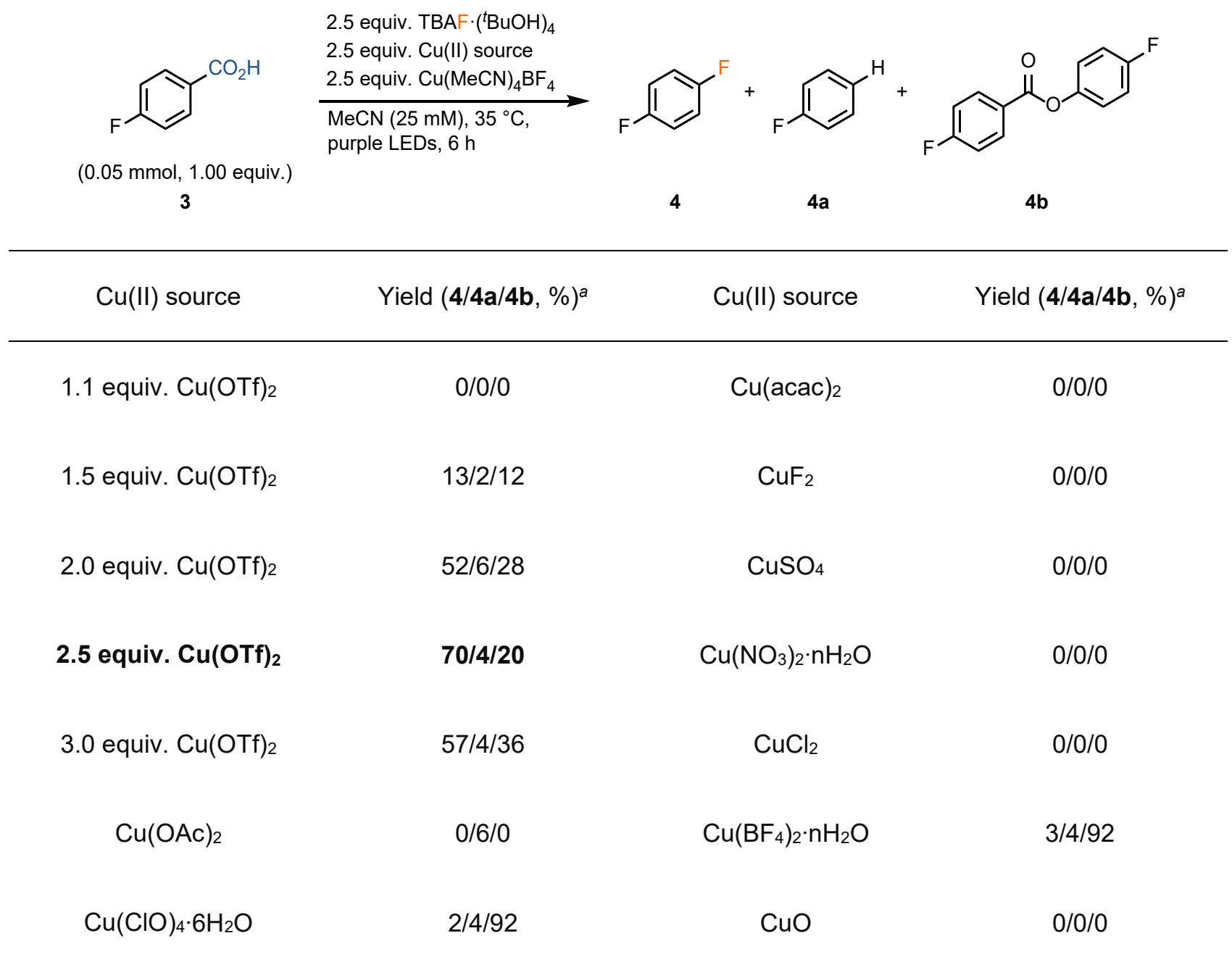

${ }^{a}{ }^{19} \mathrm{~F}$ NMR yield with 2-fluorotoluene( 2.0 equiv.) as an internal standard. 
Table S4 Cu(I) optimization

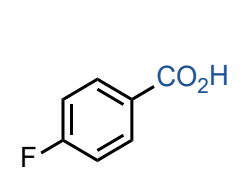

(0.05 mmol, 1.00 equiv.)

3
2.5 equiv. TBAF $\cdot\left({ }^{t} \mathrm{BuOH}\right)_{4}$

2.5 equiv. $\mathrm{Cu}(\mathrm{OTf})_{2}$

2.5 equiv. $\mathrm{Cu}(\mathrm{I})$ source

$\operatorname{MeCN}(25 \mathrm{mM}), 35^{\circ} \mathrm{C}$, purple LEDs, $6 \mathrm{~h}$
4

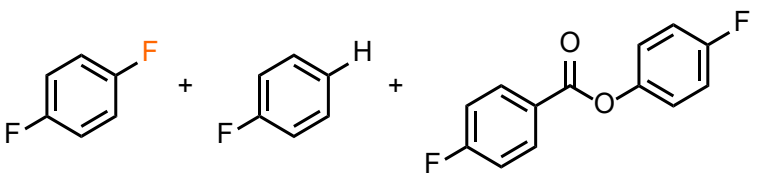

$4 a$

4b

\begin{tabular}{|c|c|c|c|}
\hline $\mathrm{Cu}(\mathrm{I})$ source & Yield $(\mathbf{4} / \mathbf{4 a} / \mathbf{4 b}, \%)^{a}$ & $\mathrm{Cu}(\mathrm{I})$ source & Yield $(4 / 4 a / 4 b, \%)^{a}$ \\
\hline no $\mathrm{Cu}(\mathrm{I})$ source & $60 / 16 / 4$ & CuSCN & $0 / 0 / 0$ \\
\hline 0.5 equiv. $\mathrm{Cu}(\mathrm{MeCN})_{4} \mathrm{BF}_{4}$ & $66 / 8 / 24$ & $\mathrm{CuCl}$ & $0 / 0 / 0$ \\
\hline 1.5 equiv. $\mathrm{Cu}(\mathrm{MeCN})_{4} \mathrm{BF}_{4}$ & $67 / 6 / 24$ & Cul & $0 / 0 / 0$ \\
\hline 2.5 equiv. $\mathrm{Cu}(\mathrm{MeCN})_{4} \mathrm{BF}_{4}$ & $70 / 4 / 20$ & $\mathrm{Cu}(\mathrm{MeCN})_{4} \mathrm{OTf}$ & $70 / 4 / 24$ \\
\hline CuOAc & $0 / 0 / 0$ & $\mathrm{Cu}_{2} \mathrm{O}$ & $30 / 8 / 20$ \\
\hline
\end{tabular}

${ }^{\text {a }}{ }^{19} \mathrm{~F}$ NMR yield with 2-fluorotoluene( 2.0 equiv.) as an internal standard.

Table S5 Control experiments

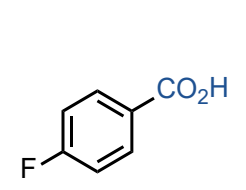

(0.05 mmol, 1.00 equiv.)

3
2.5 equiv. TBAF $\cdot\left({ }^{t} \mathrm{BuOH}\right)_{4}$

2.5 equiv. $\mathrm{Cu}(\mathrm{OTf})_{2}$

2.5 equiv. $\mathrm{Cu}(\mathrm{MeCN})_{4} \mathrm{BF}_{4}$

$\mathrm{MeCN}(25 \mathrm{mM}), 35^{\circ} \mathrm{C}$,

purple LEDs, $6 \mathrm{~h}$
$\overbrace{}^{F}+\overbrace{}^{H}+$<smiles>O=C(Oc1ccc(F)cc1)c1ccc(F)cc1</smiles>

$4 a$

4b derivation

no irradination

blue LEDs instead of purple LEDs

white CFL instead of purple LEDs

$100{ }^{\circ} \mathrm{C}$ heating instead of irradination

no TBAF·( $\left.{ }^{(B u O H}\right)_{4}$
Yield $(4 / 4 a / 4 b, \%)^{a}$

0/0/0

9/0/4

$4 / 0 / 0$

0/0/0

0/5/0 
no $\mathrm{Cu}(\mathrm{OTf})_{2}$

no pre-stirring

AgOTf instead of $\mathrm{Cu}(\mathrm{MeCN})_{4} \mathrm{BF}_{4}$

$\mathrm{Sn}(\mathrm{OTf})_{2}$ instead of $\mathrm{Cu}(\mathrm{MeCN})_{4} \mathrm{BF}_{4}$

$\mathrm{Bi}(\mathrm{OTf})_{3}$ instead of $\mathrm{Cu}(\mathrm{MeCN})_{4} \mathrm{BF}_{4}$

$\mathrm{Fe}(\mathrm{OTf})_{2}$ instead of $\mathrm{Cu}(\mathrm{MeCN})_{4} \mathrm{BF}_{4}$

5.0 equiv. $\mathrm{H}_{2} \mathrm{O}$ as additive

2.0 equiv. TEMPO as additive

2.0 equiv. $\mathrm{Na}_{2} \mathrm{SO}_{4}$ as additive
$0 / 0 / 0$

$62 / 4 / 34$

$60 / 14 / 24$

$0 / 0 / 0$

$0 / 0 / 0$

$0 / 0 / 0$

$23 / 4 / 68$

$0 / 0 / 0$

$70 / 4 / 20$

$46 / 4 / 48$

$43 / 4 / 48$

air atmosphere instead of nitrogen atmosphere

$43 / 4 / 48$

${ }^{a}{ }^{19} \mathrm{~F}$ NMR yield with 2-fluorotoluene( 2.0 equiv.) as an internal standard.

Table S6 Effects of reaction temperature on the reaction yield
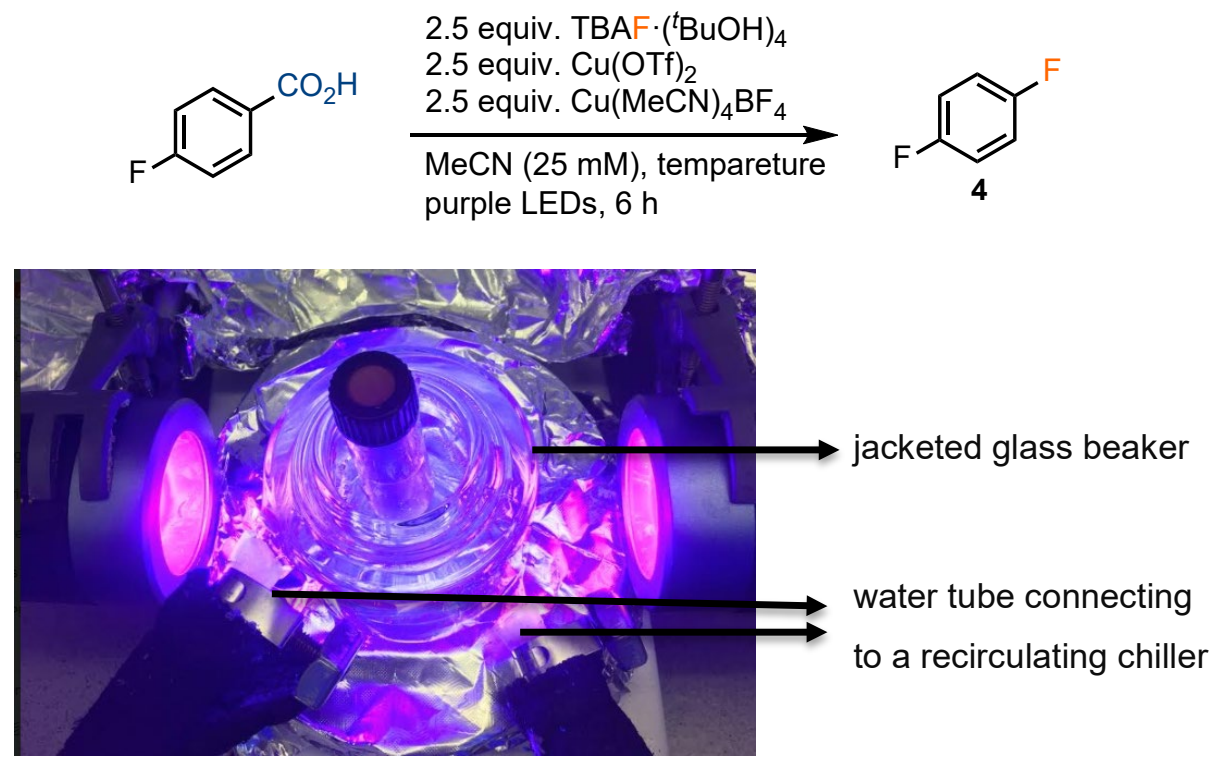

Figure S2. Photo of the irradiation setup for temperature control

In a nitrogen-filled glovebox, a $16 \mathrm{~mL}$ borosilicate vial equipped with a magnetic stir bar was charged with 4fluorobenzoic acid (28.0 mg, $0.200 \mathrm{mmol}, 1.00$ equiv.), Cu(OTf)2 (181 mg, $0.500 \mathrm{mmol}, 2.50$ equiv.), 
$\mathrm{Cu}(\mathrm{MeCN})_{4} \mathrm{BF}_{4}$ (157 mg, $0.500 \mathrm{mmol}, 2.50$ equiv.), and TBAF.('BuOH) 4 (279 mg, $0.500 \mathrm{mmol}, 2.50$ equiv.). $\operatorname{MeCN}(8.0 \mathrm{~mL}, \mathrm{c}=25 \mathrm{mM})$ was then added into the vial. The vial was sealed with a Teflon cap and taken out of the glovebox. The reaction mixture was stirred without irradiation for $30 \mathrm{~min}$ at ambient temperature. For the reaction performed at $25^{\circ} \mathrm{C}$ or $35^{\circ} \mathrm{C}$, the vial was placed in a water bath in a jacketed glass beaker connected to a recirculating chiller; while for the reaction performed at $50^{\circ} \mathrm{C}$, the vial was placed in an oil bath heated in a crystallizing dish atop a hotplate stirrer. The reaction mixture was then irradiated for $6 \mathrm{~h}$ by two purple LEDs (Kessil PR160-390 $\mathrm{nm}$ LEDs, $5 \mathrm{~cm}$ away from the vial). After being irradiated for $6 \mathrm{~h}$, the reaction mixture was returned to room temperature. 2-Fluorotoluene $(22.0 \mathrm{mg}, 22.0 \mu \mathrm{L}, 0.200 \mathrm{mmol}, 1.00$ equiv.) was added as an internal standard. The reaction mixture was diluted with $\mathrm{CD}_{3} \mathrm{CN}$, and the ${ }^{19} \mathrm{~F}$ NMR spectrum was measured. The yield of product 1,4 -difluorobenzene $(4, \delta-121.1(\mathrm{~m}) \mathrm{ppm})$ was determined by ${ }^{19} \mathrm{~F}$ NMR integration relative to the internal standard $(\delta-119.4(\mathrm{~m}) \mathrm{ppm})$.

\begin{tabular}{c|ccc}
\hline temperature $\left({ }^{\circ} \mathrm{C}\right)$ & 25 & 35 & 50 \\
\hline yield $(4, \%)$ & 71 & 70 & 65 \\
\hline
\end{tabular}

Table S6. Effects of reaction temperature on the reaction yield

The above results indicate that the reaction yield is not sensitive to the reaction temperature (in the range of 25 to $50{ }^{\circ} \mathrm{C}$ ). Thus, in the standard procedure, the reaction temperature was kept at approximately $35{ }^{\circ} \mathrm{C}$ through cooling with a fan for the simplicity of reaction setup.

\section{Photo-induced LMCT-enabled aromatic decarboxylative fluorination}

Mavacoxib (2)
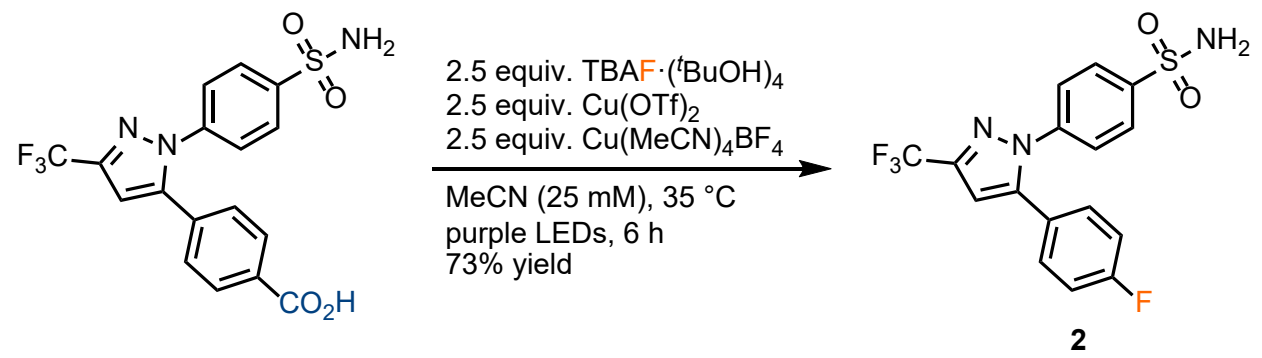

In a nitrogen-filled glovebox, a $16 \mathrm{~mL}$ borosilicate vial equipped with a magnetic stir bar was charged with carboxycelecoxib (1) (82.3 mg, $0.200 \mathrm{mmol}, 1.00$ equiv.), Cu(OTf) 2 (181 mg, $0.500 \mathrm{mmol}, 2.50$ equiv.), $\mathrm{Cu}(\mathrm{MeCN})_{4} \mathrm{BF}_{4}\left(157 \mathrm{mg}, 0.500 \mathrm{mmol}, 2.50\right.$ equiv.), and TBAF.('BuOH) ${ }_{4}(279 \mathrm{mg}, 0.500 \mathrm{mmol}, 2.50$ equiv.). MeCN ( $8.0 \mathrm{~mL}, \mathrm{C}=25 \mathrm{mM}$ ) was then added into the vial. The vial was sealed with a Teflon cap, taken out of the glovebox and placed $5 \mathrm{~cm}$ away from two purple LEDs (Kessil PR160-390 nm LEDs). The reaction mixture was stirred without irradiation for $30 \mathrm{~min}$ at ambient temperature and then irradiated for $6 \mathrm{~h}$ while maintaining the temperature at approximately $35^{\circ} \mathrm{C}$ through cooling with a fan. After irradiation, the reaction mixture was transferred to a $25 \mathrm{~mL}$ round-bottom flask and evaporated to dryness. The desidue was dissolved in DCM (20 
$\mathrm{mL}$ ), transferred into a separatory funnel containing $5 \mathrm{~mL}$ saturated aqueous $\mathrm{NH}_{4} \mathrm{Cl}$ and $5 \mathrm{~mL} \mathrm{H}_{2} \mathrm{O}$, and the layers were separated. The organic layer was collected, and the aqueous layer was further extracted with DCM $\left(3 \times\right.$ ca. $20 \mathrm{~mL}$ ). The combined organic layer was dried over $\mathrm{Na}_{2} \mathrm{SO}_{4}$, filtered, and the solvent was removed under reduced pressure. The residue was purified by chromatography on silica gel $(E A / D C M=1 / 8, v / v)$ to yield a mixture. The mixture was then purified by preparative HPLC (23.9 min, YMC-Actus Pro C18 (150 × $30.0 \mathrm{~mm}$ : $5 \mu \mathrm{m}+50 \times 30.0 \mathrm{~mm}: 5 \mu \mathrm{m}), \mathrm{MeCN} / \mathrm{H}_{2} \mathrm{O}=40 / 60$ to 50/50, v/v over $20 \mathrm{~min}, 42.5 \mathrm{~mL} / \mathrm{min}, 308 \mathrm{~K}, 254 \mathrm{~nm}$ ). The fraction was evaporated under vacuum to remove most of the $\mathrm{MeCN}$, and the remaining mixture was extracted with DCM ( $3 \times$ ca. $50 \mathrm{~mL})$. The combined organic layer was dried over $\mathrm{Na}_{2} \mathrm{SO}_{4}$, filtered, and the solvent was removed under reduced pressure to afford mavacoxib (2) (56.3 mg, $146 \mu \mathrm{mol}, 73 \%)$ as a colorless solid.

$\mathbf{R} \boldsymbol{f}=0.33(\mathrm{EA} / \mathrm{DCM}=1 / 9, \mathrm{v} / \mathrm{v})$.

\section{NMR Spectroscopy:}

${ }^{1} \mathrm{H}$ NMR $\left(500 \mathrm{MHz}, \mathrm{CD}_{2} \mathrm{Cl}_{2}, 298 \mathrm{~K}, \delta\right): 7.90(\mathrm{~d}, J=8.7 \mathrm{~Hz}, 2 \mathrm{H}), 7.46(\mathrm{~d}, J=8.7 \mathrm{~Hz}, 2 \mathrm{H}), 7.29-7.21(\mathrm{~m}$, 2H), $7.09(\mathrm{t}, J=8.7 \mathrm{~Hz}, 2 \mathrm{H}), 6.80(\mathrm{~s}, 1 \mathrm{H}), 5.23(\mathrm{~s}, 2 \mathrm{H}) \mathrm{ppm}$.

${ }^{13} \mathrm{C}$ NMR (126 MHz, $\left.\mathrm{CD}_{2} \mathrm{Cl}_{2}, 298 \mathrm{~K}, \delta\right): 163.7$ (d, J = 250.3 Hz), 144.7, 144.2 (q, J = 38.6 Hz), 142.6, 142.2, $131.4(\mathrm{~d}, \mathrm{~J}=8.8 \mathrm{~Hz}), 127.9,125.9,125.3$ (d, J = 3.5 Hz), 121.6 (q, J = 268.9 Hz), 116.6 (d, J = $22.0 \mathrm{~Hz}$ ), $107.0(\mathrm{~d}, \mathrm{~J}=2.3 \mathrm{~Hz}) \mathrm{ppm}$.

${ }^{19} \mathrm{~F}$ NMR (471 MHz, $\left.\mathrm{CD}_{2} \mathrm{Cl}_{2}, 298 \mathrm{~K}, \delta\right):-62.7(\mathrm{~s}),-111.5(\mathrm{~m}) \mathrm{ppm}$.

HRMS-ESI (m/z) calculated for $\mathrm{C}_{16} \mathrm{H}_{10} \mathrm{~N}_{3} \mathrm{O}_{2} \mathrm{SF}_{4}^{-}$[M-H]', 384.0435; found, 384.0441; deviation: -1.36 ppm.

\section{1,4-Difluorobenzene (4), fluorobenzene (4a) and 4-fluorophenyl 4-fluorobenzoate (4b)}

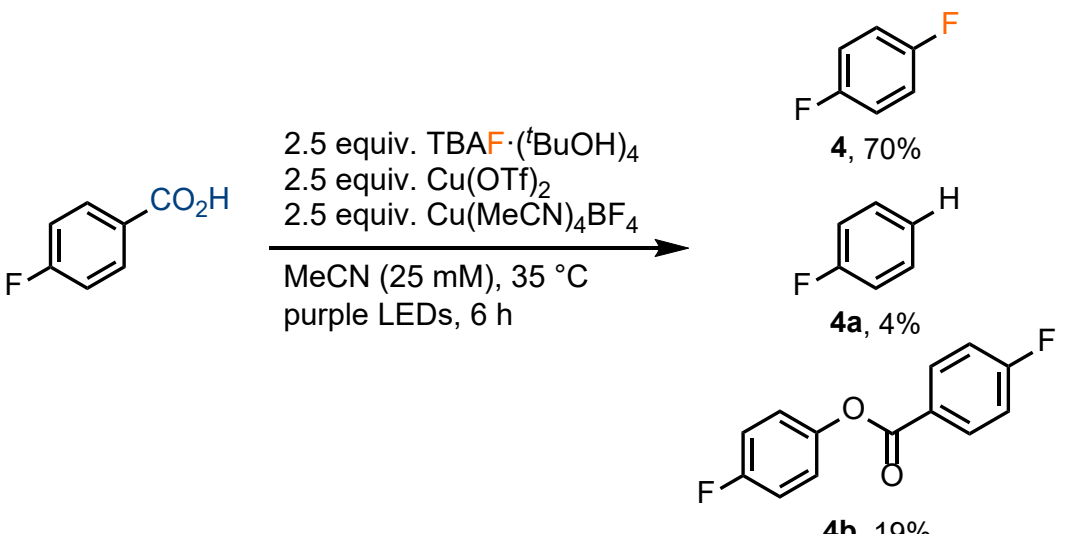

In a nitrogen-filled glovebox, a $16 \mathrm{~mL}$ borosilicate vial equipped with a magnetic stir bar was charged with 4fluorobenzoic acid (28.0 mg, $0.200 \mathrm{mmol}, 1.00$ equiv.), Cu(OTf)2 (181 mg, $0.500 \mathrm{mmol}, 2.50$ equiv.), $\mathrm{Cu}(\mathrm{MeCN})_{4} \mathrm{BF}_{4}\left(157 \mathrm{mg}, 0.500 \mathrm{mmol}, 2.50\right.$ equiv.), and TBAF $\cdot\left({ }^{t} \mathrm{BuOH}\right)_{4}(279 \mathrm{mg}, 0.500 \mathrm{mmol}, 2.50$ equiv.). $\operatorname{MeCN}(8.0 \mathrm{~mL}, \mathrm{c}=25 \mathrm{mM})$ was then added into the vial. The vial was sealed with a Teflon cap, taken out of the glovebox and placed $5 \mathrm{~cm}$ away from two purple LEDs (Kessil PR160-390 nm LEDs). The reaction mixture was stirred without irradiation for $30 \mathrm{~min}$ at ambient temperature and then irradiated for $6 \mathrm{~h}$ while maintaining the temperature at approximately $35^{\circ} \mathrm{C}$ through cooling with a fan. After being irradiated for $6 \mathrm{~h}$, the reaction 
mixture was cooled to room temperature. 2-fluorotoluene (22.0 mg, $22.0 \mu \mathrm{L}, 0.200 \mathrm{mmol}, 1.00$ equiv.) was added as an internal standard. The reaction mixture was diluted with $\mathrm{CD}_{3} \mathrm{CN}$, and the ${ }^{19} \mathrm{~F}$ NMR spectrum was measured. The yield of product 1,4-difluorobenzene $(4,69 \%$ yield, $\delta-121.1(\mathrm{~m}) \mathrm{ppm}$, Figure S3) and the yield of side-product fluorobenzene $(4 \mathrm{a}, 4 \%$ yield, $\delta-114.9(\mathrm{~m}) \mathrm{ppm}$, Figure $\mathrm{S} 3)$ were determined by ${ }^{19} \mathrm{~F}$ NMR integration relative to the internal standard $(\delta-119.4(\mathrm{~m}) \mathrm{ppm})$. The identity of $\mathbf{4}$ and $\mathbf{4 a}$ were further confirmed by GCMS analysis (Figure S4 and Figure S5). The NMR and GCMS samples were recycled and recombined with the remaining reaction mixture. The resulting mixture was transferred to a $25 \mathrm{~mL}$ round-bottom flask and evaporated to dryness. The desidue was dissolved in DCM $(20 \mathrm{~mL})$, transferred into a separatory funnel containing $5 \mathrm{~mL}$ saturated aqueous $\mathrm{NH}_{4} \mathrm{Cl}$ and $5 \mathrm{~mL} \mathrm{H} 2 \mathrm{O}$, and the layers were separated. The organic layer was collected, and the aqueous layer was further extracted with DCM ( $3 \times$ ca. $20 \mathrm{~mL})$. The combined organic layer was dried over $\mathrm{Na}_{2} \mathrm{SO}_{4}$, filtered, and the solvent was removed under reduced pressure. The residue was purified by chromatography on silica gel (hexanes/DCM $=5 / 1, v / v$ ) to yield 4-fluorophenyl 4-fluorobenzoate (4b) $(4.5 \mathrm{mg}, 19 \mu \mathrm{mol}, 19 \%)$ as a colorless solid.

The yield of 4 reported in the manuscript $(70 \%)$ represents an average of two runs [69\% (above) and $71 \%$ ].

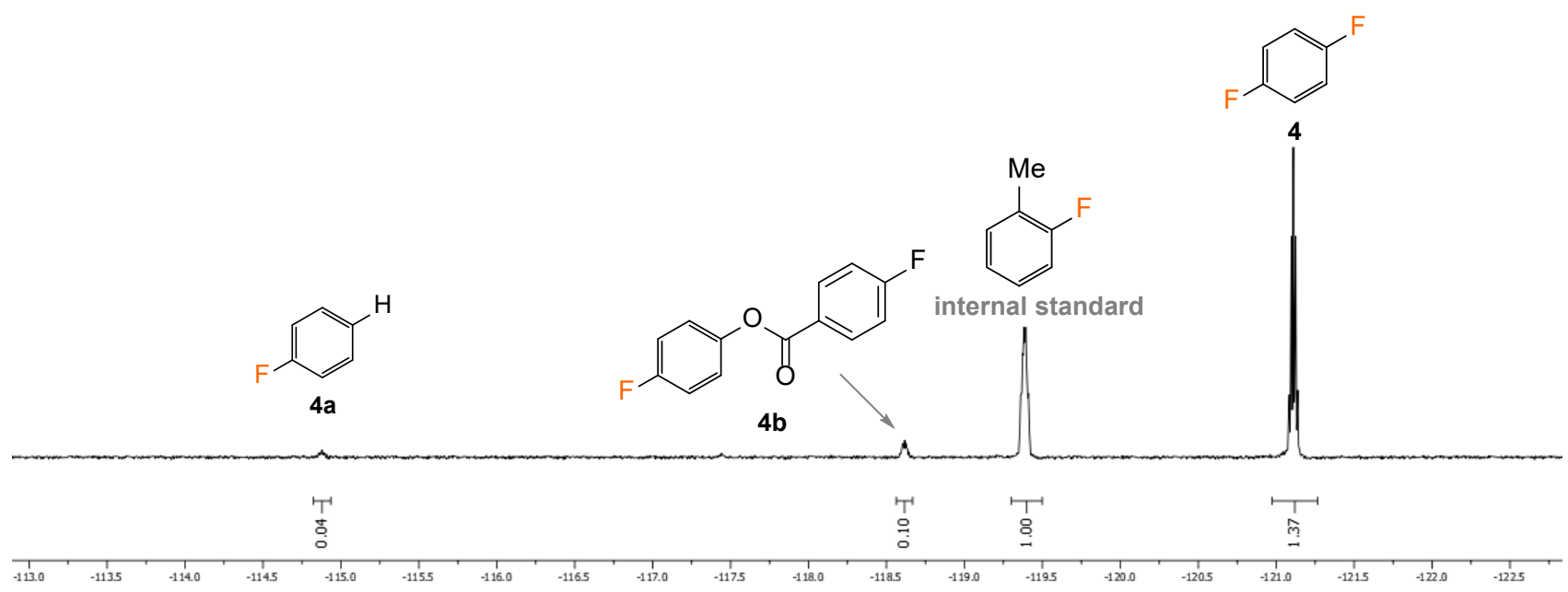

Figure S3. ${ }^{19} \mathrm{~F}$ NMR of the resulting mixtures for product $\mathbf{4}$, side-products $\mathbf{4 a}$ and $\mathbf{4 b}$.

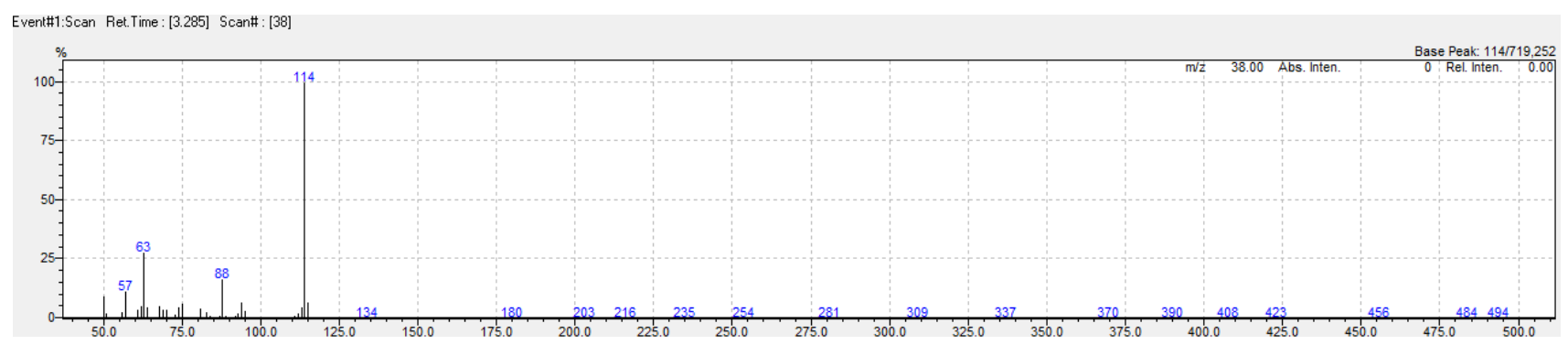

Figure S4. Mass spectrum of product 4 peak from GCMS 


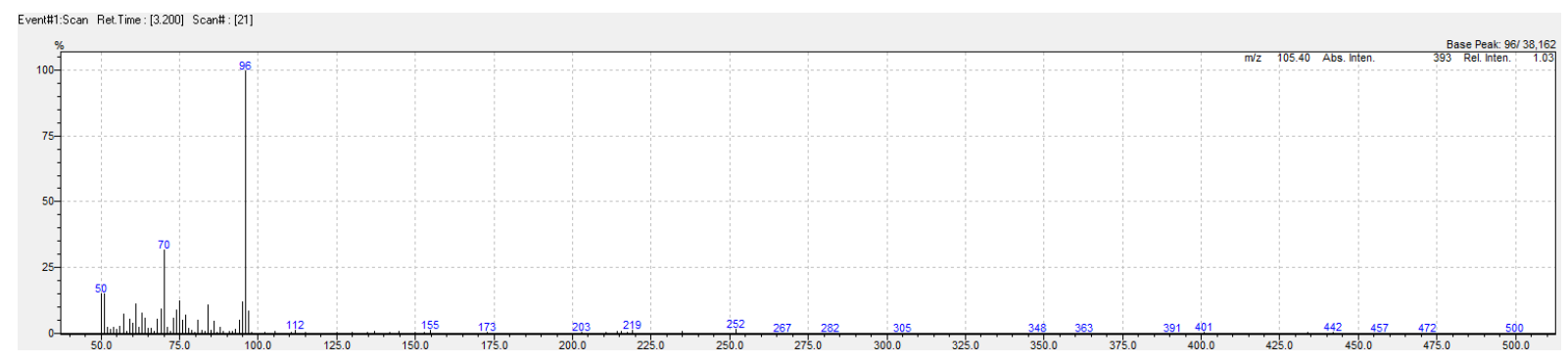

Figure S5. Mass spectrum of side-product 4a peak from GCMS

4-Fluorophenyl 4-fluorobenzoate (4c)

$\mathbf{R f}=0.25($ hexanes/DCM $=4 / 1, \mathrm{v} / \mathrm{v})$.

NMR Spectroscopy:

${ }^{1} \mathrm{H}$ NMR $\left(500 \mathrm{MHz}, \mathrm{CDCl}_{3}, 298 \mathrm{~K}, \delta\right):$ 8.25-8.18 (m, 2H), 7.22-7.16 (m, 4H), 7.14-7.08 (m, 2H) ppm.

${ }^{13} \mathrm{C}$ NMR $\left(126 \mathrm{MHz}, \mathrm{CDCl}_{3}, 298 \mathrm{~K}, \delta\right): 166.3$ (d, J = 255.5 Hz), 164.3, 160.5 (d, J = 244.4 Hz), 146.7 (d, J $=2.9 \mathrm{~Hz}), 132.9(\mathrm{~d}, J=9.4 \mathrm{~Hz}), 125.7(\mathrm{~d}, J=3.0 \mathrm{~Hz}), 123.2(\mathrm{~d}, J=8.4 \mathrm{~Hz}), 116.3(\mathrm{~d}, J=23.4 \mathrm{~Hz}), 115.9$ $(\mathrm{d}, J=22.1 \mathrm{~Hz}) \mathrm{ppm}$.

${ }^{19} \mathrm{~F}$ NMR (471 MHz, $\left.\mathrm{CDCl}_{3}, 298 \mathrm{~K}, \delta\right):-104.1(\mathrm{~m}),-116.7(\mathrm{~m}) \mathrm{ppm}$.

HRMS-EI (m/z) calculated for $\mathrm{C}_{13} \mathrm{H}_{8} \mathrm{O}_{2} \mathrm{~F}_{2}{ }^{+}[\mathrm{M}]^{+}, 234.0487$; found, 234.0487; deviation: -0.01 ppm.

1-Fluoro-4-nitrobenzene (5)

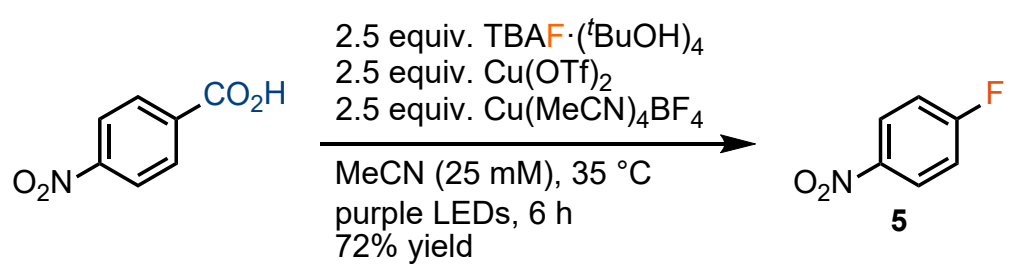

In a nitrogen-filled glovebox, a $16 \mathrm{~mL}$ borosilicate vial equipped with a magnetic stir bar was charged with 4nitrobenzoic acid (33.4 mg, $0.200 \mathrm{mmol}, 1.00$ equiv.), $\mathrm{Cu}(\mathrm{OTf})_{2}$ (181 $\mathrm{mg}, 0.500 \mathrm{mmol}, 2.50$ equiv.), $\mathrm{Cu}(\mathrm{MeCN})_{4} \mathrm{BF}_{4}\left(157 \mathrm{mg}, 0.500 \mathrm{mmol}, 2.50 \text { equiv.), and TBAF.( }{ }^{\mathrm{B}} \mathrm{BuOH}\right)_{4}(279 \mathrm{mg}, 0.500 \mathrm{mmol}, 2.50$ equiv.). $\operatorname{MeCN}(8.0 \mathrm{~mL}, \mathrm{c}=25 \mathrm{mM}$ ) was then added into the vial. The vial was sealed with a Teflon cap, taken out of the glovebox and placed $5 \mathrm{~cm}$ away from two purple LEDs (Kessil PR160-390 nm LEDs). The reaction mixture was stirred without irradiation for $30 \mathrm{~min}$ at ambient temperature and then irradiated for $6 \mathrm{~h}$ while maintaining the temperature at approximately $35^{\circ} \mathrm{C}$ through cooling with a fan. After being irradiated for $6 \mathrm{~h}$, the reaction mixture was cooled to room temperature. 2-fluorotoluene $(22.0 \mathrm{mg}, 22.0 \mu \mathrm{L}, 0.200 \mathrm{mmol}, 1.00$ equiv.) was added as an internal standard. The reaction mixture was diluted with $\mathrm{CD}_{3} \mathrm{CN}$, and the yield of 1-fluoro-4nitrobenzene (5) was determined by ${ }^{19} \mathrm{~F}$ NMR integration relative to the internal standard $(73 \%$ yield, standard: $\delta-119.4(\mathrm{~m}) \mathrm{ppm}$, and $\mathbf{5}$ : $\delta-104.5(\mathrm{~m}) \mathrm{ppm}$, Figure $\mathbf{S 6}$ ). The identity of the product was further confirmed by GCMS analysis (Figure $\mathbf{S 7}$ ). 
The yield of 5 reported in the manuscript (72\%) represents an average of two runs [73\% (above) and $71 \%]$.

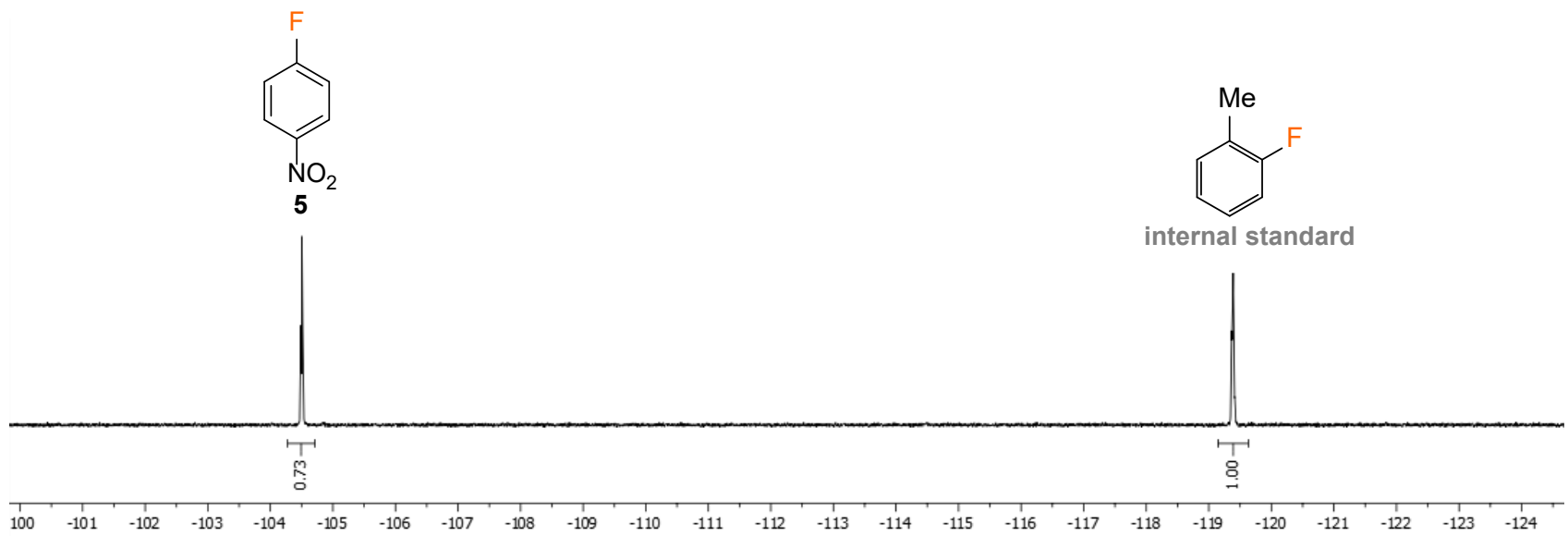

Figure S6. ${ }^{19} \mathrm{~F}$ NMR of resulting mixtures for product 5.

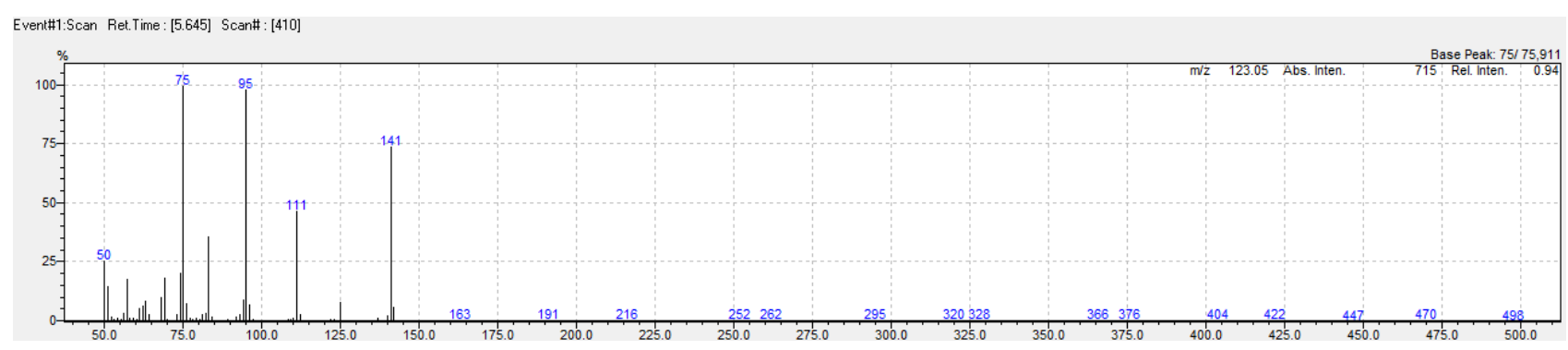

Figure S7. Mass spectrum of product 5 peak from GCMS

2-Fluoroquinoline (6)

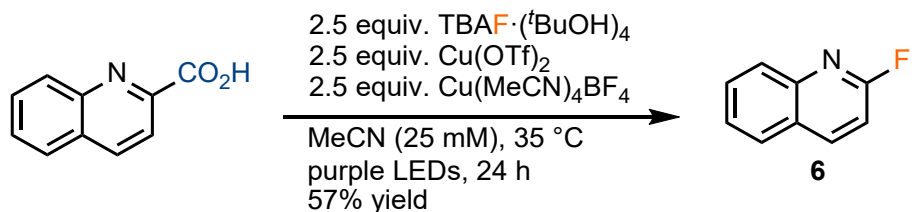

In a nitrogen-filled glovebox, a $16 \mathrm{~mL}$ borosilicate vial equipped with a magnetic stir bar was charged with quinoline-2-carboxylic acid (34.6 mg, $0.200 \mathrm{mmol}, 1.00$ equiv.), Cu(OTf)2 (181 mg, $0.500 \mathrm{mmol}, 2.50$ equiv.), $\mathrm{Cu}(\mathrm{MeCN})_{4} \mathrm{BF}_{4}$ (157 mg, $0.500 \mathrm{mmol}, 2.50$ equiv.), and TBAF.('BuOH) 4 (279 mg, $0.500 \mathrm{mmol}, 2.50$ equiv.). $\operatorname{MeCN}(8.0 \mathrm{~mL}, \mathrm{c}=25 \mathrm{mM})$ was then added into the vial. The vial was sealed with a Teflon cap, taken out of the glovebox and placed $5 \mathrm{~cm}$ away from two purple LEDs (Kessil PR160-390 nm LEDs The reaction mixture was stirred without irradiation for $30 \mathrm{~min}$ at ambient temperature and then irradiated for $24 \mathrm{~h}$ while maintaining the temperature at approximately $35^{\circ} \mathrm{C}$ through cooling with a fan. After irradiation, the reaction mixture was transferred to a $25 \mathrm{~mL}$ round-bottom flask and evaporated to dryness. The desidue was dissolved in DCM (20 $\mathrm{mL}$ ), transferred into a separatory funnel containing $5 \mathrm{~mL}$ saturated aqueous $\mathrm{NH}_{4} \mathrm{Cl}$ and $5 \mathrm{~mL} \mathrm{H}_{2} \mathrm{O}$, and the layers were separated. The organic layer was collected, and the aqueous layer was further extracted with DCM ( $3 \times$ ca. $20 \mathrm{~mL}$ ). The combined organic layer was dried over $\mathrm{Na}_{2} \mathrm{SO}_{4}$, filtered, and the solvent was removed under reduced pressure. The residue was purified by chromatography on silica gel $($ DCM/pentane $=1 / 5, v / v)$ 
to yield a mixture. The mixture was further purified by preparative TLC (DCM/pentane $1 / 9, \mathrm{v} / \mathrm{v})$ to afford 2fluoroquinoline (6) (16.7 mg, $113 \mu \mathrm{mol}, 57 \%)$ as a colorless oil.

$\mathbf{R} \boldsymbol{f}=0.70(\mathrm{DCM} / \mathrm{hexanes}=1 / 4, \mathrm{v} / \mathrm{v})$

\section{NMR Spectroscopy:}

${ }^{1} \mathrm{H}$ NMR $\left(500 \mathrm{MHz}, \mathrm{CDCl}_{3}, 298 \mathrm{~K}, \delta\right): 8.25(\mathrm{t}, J=8.4 \mathrm{~Hz}, 1 \mathrm{H}), 7.96(\mathrm{~d}, J=8.4 \mathrm{~Hz}, 1 \mathrm{H}), 7.85$ (dd, $J=8.2$, $1.4 \mathrm{~Hz}, 1 \mathrm{H}$ ), 7.74 (ddd, $J=8.4,6.9,1.5 \mathrm{~Hz}, 1 \mathrm{H}$ ), 7.54 (ddd, $J=8.2,6.9,1.2 \mathrm{~Hz}, 1 \mathrm{H}$ ), 7.09 (dd, $J=8.8,2.7$ $\mathrm{Hz}, 1 \mathrm{H}) \mathrm{ppm}$.

${ }^{13} \mathrm{C}$ NMR (126 MHz, $\left.\mathrm{CDCl}_{3}, 298 \mathrm{~K}, \delta\right): 161.3(\mathrm{~d}, J=242.3 \mathrm{~Hz}), 145.9(\mathrm{~d}, J=16.7 \mathrm{~Hz}), 142.1$ (d, $J=9.7$ $\mathrm{Hz}), 130.8,128.3,127.7,127.0,126.3(\mathrm{~d}, J=2.4 \mathrm{~Hz}), 110.2(\mathrm{~d}, J=42.4 \mathrm{~Hz}) \mathrm{ppm}$.

${ }^{19}$ F NMR (471 MHz, CDCl $\left.3,298 \mathrm{~K}, \delta\right):-61.7$ (s) ppm.

HRMS-EI (m/z) calculated for $\mathrm{C}_{9} \mathrm{H}_{6} \mathrm{NF}^{+}[\mathrm{M}]^{+}, 147: 0479$; found, 147:0479; deviation: $-0.02 \mathrm{ppm}$.

\section{4-Fluorobenzophenone (7)}
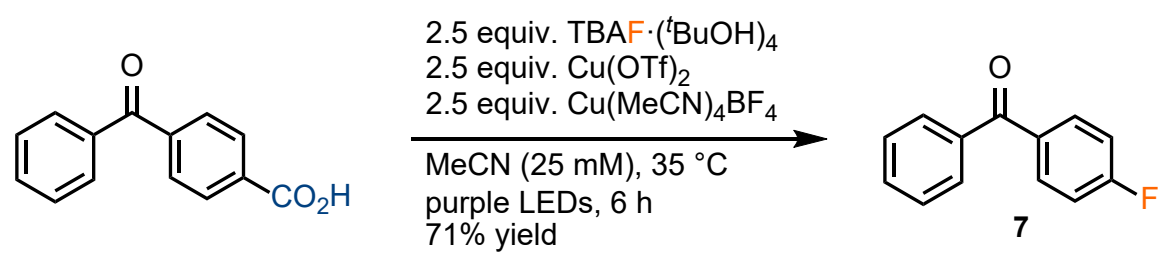

In a nitrogen-filled glovebox, a $16 \mathrm{~mL}$ borosilicate vial equipped with a magnetic stir bar was charged with 4benzoylbenzoic acid (45.2 mg, $0.200 \mathrm{mmol}, 1.00$ equiv.), Cu(OTf)2 (181 mg, $0.500 \mathrm{mmol}, 2.50$ equiv.), $\mathrm{Cu}(\mathrm{MeCN})_{4} \mathrm{BF}_{4}$ (157 mg, $0.500 \mathrm{mmol}, 2.50$ equiv.), and TBAF.( $\left.{ }^{\mathrm{BuOH}}\right)_{4}(279 \mathrm{mg}, 0.500 \mathrm{mmol}, 2.50$ equiv.). $\operatorname{MeCN}(8.0 \mathrm{~mL}, \mathrm{c}=25 \mathrm{mM})$ was then added into the vial. The vial was sealed with a Teflon cap, taken out of the glovebox and placed $5 \mathrm{~cm}$ away from two purple LEDs (Kessil PR160-390 nm LEDs). The reaction mixture was stirred without irradiation for $30 \mathrm{~min}$ at ambient temperature and then irradiated for $6 \mathrm{~h}$ while maintaining the temperature at approximately $35^{\circ} \mathrm{C}$ through cooling with a fan. After irradiation, the reaction mixture was transferred to a $25 \mathrm{~mL}$ round-bottom flask and evaporated to dryness. The desidue was dissolved in DCM (20 $\mathrm{mL}$ ), transferred into a separatory funnel containing $5 \mathrm{~mL}$ saturated aqueous $\mathrm{NH}_{4} \mathrm{Cl}$ and $5 \mathrm{~mL} \mathrm{H}_{2} \mathrm{O}$, and the layers were separated. The organic layer was collected, and the aqueous layer was further extracted with DCM $\left(3 \times\right.$ ca. $20 \mathrm{~mL}$ ). The combined organic layer was dried over $\mathrm{Na}_{2} \mathrm{SO}_{4}$, filtered, and the solvent was removed under reduced pressure. The residue was purified by chromatography on silica gel $(E A / h e x a n e s=1 / 50, v / v)$ to afford 4-fluorobenzophenone (7) (28.4 mg, $142 \mu \mathrm{mol}, 71 \%)$ as a colorless solid.

$\boldsymbol{R} \boldsymbol{f}=0.33(\mathrm{EA}, 1 / 25, \mathrm{v} / \mathrm{v})$.

\section{NMR Spectroscopy:}

${ }^{1} \mathrm{H}$ NMR $\left(500 \mathrm{MHz}, \mathrm{CDCl}_{3}, 298 \mathrm{~K}, \delta\right): 7.89-7.81(\mathrm{~m}, 2 \mathrm{H}), 7.79-7.75(\mathrm{~m}, 2 \mathrm{H}), 7.63-7.56(\mathrm{~m}, 1 \mathrm{H}), 7.49(\mathrm{t}, \mathrm{J}$ $=7.7 \mathrm{~Hz}, 2 \mathrm{H}), 7.20-7.12(\mathrm{~m}, 2 \mathrm{H}) \mathrm{ppm}$. 
${ }^{13} \mathrm{C}$ NMR (126 MHz, $\left.\mathrm{CDCl}_{3}, 298 \mathrm{~K}, \delta\right): 195.4,165.5$ (d, $\left.J=254.0 \mathrm{~Hz}\right), 137.6,133.9$ (d, J = 3.0 Hz), 132.8 (d, $J=9.0 \mathrm{~Hz}), 132.6,130.0,128.5,115.6(\mathrm{~d}, J=22.0 \mathrm{~Hz}) \mathrm{ppm}$.

${ }^{19} \mathrm{~F}$ NMR $\left(471 \mathrm{MHz}, \mathrm{CDCl}_{3}, 298 \mathrm{~K}, \delta\right):-106.0(\mathrm{~m}) \mathrm{ppm}$.

HRMS-EI (m/z) calculated for $\mathrm{C}_{13} \mathrm{H}_{9} \mathrm{OF}^{+}[\mathrm{M}]^{+}, 200.0632$; found, 200.0633; deviation: -0.38 ppm.

\section{D-glucose derivative 8}
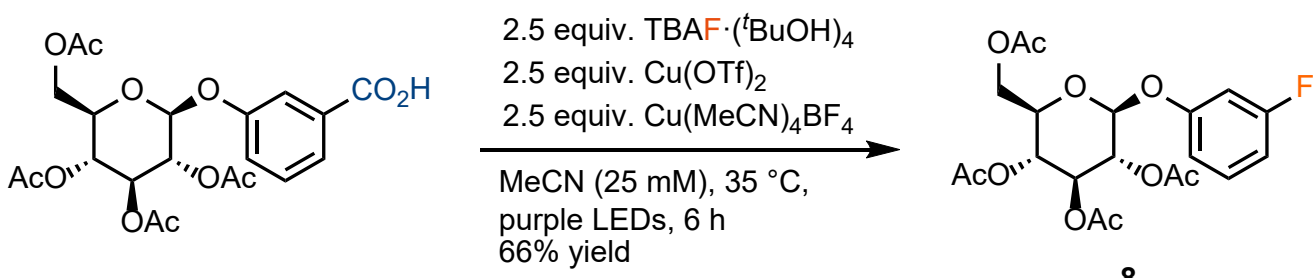

8

In a nitrogen-filled glovebox, a $16 \mathrm{~mL}$ borosilicate vial equipped with a magnetic stir bar was charged with Dglucose derivative $\mathbf{S} 3$ (93.7 mg, $0.200 \mathrm{mmol}, 1.00$ equiv.), $\mathrm{Cu}(\mathrm{OTf})_{2}$ (181 mg, $0.500 \mathrm{mmol}, 2.50$ equiv.), $\mathrm{Cu}(\mathrm{MeCN})_{4} \mathrm{BF}_{4}$ (157 mg, $0.500 \mathrm{mmol}, 2.50$ equiv.), and TBAF.('BuOH) 4 (279 mg, $0.500 \mathrm{mmol}, 2.50$ equiv.). $\operatorname{MeCN}(8.0 \mathrm{~mL}, \mathrm{c}=25 \mathrm{mM})$ was then added into the vial. The vial was sealed with a Teflon cap, taken out of the glovebox and placed $5 \mathrm{~cm}$ away from two purple LEDs (Kessil PR160-390 nm LEDs). The reaction mixture was stirred without irradiation for $30 \mathrm{~min}$ at ambient temperature and then irradiated for $6 \mathrm{~h}$ while maintaining the temperature at approximately $35^{\circ} \mathrm{C}$ through cooling with a fan. After irradiation, the reaction mixture was transferred to a $25 \mathrm{~mL}$ round-bottom flask and evaporated to dryness. The desidue was dissolved in DCM (20 $\mathrm{mL}$ ), transferred into a separatory funnel containing $5 \mathrm{~mL}$ saturated aqueous $\mathrm{NH}_{4} \mathrm{Cl}$ and $5 \mathrm{~mL} \mathrm{H}_{2} \mathrm{O}$, and the layers were separated. The organic layer was collected, and the aqueous layer was further extracted with DCM ( $3 \times$ ca. $20 \mathrm{~mL}$ ). The combined organic layer was dried over $\mathrm{Na}_{2} \mathrm{SO}_{4}$, filtered, and the solvent was removed under reduced pressure. The residue was purified by chromatography on silica gel $(E A / h e x a n e s=1 / 2, v / v)$ to yield a mixture. The mixture was further purified by preparative HPLC (19.1 min, YMC-Actus Pro C18 (150 × $\left.30.0 \mathrm{~mm}: 5 \mu \mathrm{m}+50 \times 30.0 \mathrm{~mm}: 5 \mu \mathrm{m}), \mathrm{MeCN} / \mathrm{H}_{2} \mathrm{O}=45 / 55, \mathrm{v} / \mathrm{v}, 42.5 \mathrm{~mL} / \mathrm{min}, 308 \mathrm{~K}, 254 \mathrm{~nm}\right)$. The fraction was evaporated under vacuum to remove most of the $\mathrm{MeCN}$, and the remaining mixture was extracted with DCM $(3 \times$ ca. $50 \mathrm{~mL})$. The combined organic layer was dried over $\mathrm{Na}_{2} \mathrm{SO}_{4}$, filtered, and the solvent was removed under reduced pressure to afford the D-glucose derivative $8(58.4 \mathrm{mg}, 132 \mu \mathrm{mol}, 66 \%)$ as a colorless solid.

$\boldsymbol{R} \boldsymbol{f}=0.32(\mathrm{EA} / \mathrm{hexanes}=1 / 2, \mathrm{v} / \mathrm{v})$.

\section{NMR Spectroscopy:}

${ }^{1} \mathrm{H}$ NMR $\left(500 \mathrm{MHz}, \mathrm{CDCl}_{3}, 298 \mathrm{~K}, \delta\right): 7.23(\mathrm{td}, J=8.3,6.7 \mathrm{~Hz}, 1 \mathrm{H}), 6.81-6.70(\mathrm{~m}, 3 \mathrm{H}), 5.33-5.22(\mathrm{~m}, 2 \mathrm{H})$, $5.14(\mathrm{dd}, J=10.1,8.9 \mathrm{~Hz}, 1 \mathrm{H}), 5.06(\mathrm{~d}, J=7.4 \mathrm{~Hz}, 1 \mathrm{H}), 4.26(\mathrm{dd}, J=12.3,5.9 \mathrm{~Hz}, 1 \mathrm{H}), 4.17$ (dd, $J=12.2$, $2.5 \mathrm{~Hz}, 1 \mathrm{H}$ ), 3.87 (ddd, J = 10.1, 5.8, $2.5 \mathrm{~Hz}, 1 \mathrm{H}$ ), 2.08 (s, 3H), 2.05 (s, 3H), 2.04 (s, 3H), 2.03 (s, 3H) ppm.

${ }^{13} \mathrm{C}$ NMR $\left(126 \mathrm{MHz}, \mathrm{CDCl}_{3}, 298 \mathrm{~K}, \delta\right): 170.7,170.3,169.5,169.4,163.4(\mathrm{~d}, J=246.4 \mathrm{~Hz}), 158.0(\mathrm{~d}, J=$ $10.7 \mathrm{~Hz}), 130.5$ (d, $J=9.6 \mathrm{~Hz}), 112.8$ (d, $J=3.0 \mathrm{~Hz}), 110.3$ (d, $J=21.0 \mathrm{~Hz}), 104.8$ (d, $J=25.1 \mathrm{~Hz}), 99.0$, 
$72.8,72.3,71.2,68.4,62.1,20.73,20.72,20.71,20.69$ ppm.

${ }^{19} \mathrm{~F}$ NMR (471 MHz, $\left.\mathrm{CDCl}_{3}, 298 \mathrm{~K}, \delta\right):-110.9(\mathrm{~m}) \mathrm{ppm}$.

HRMS-ESI (m/z) calculated for $\mathrm{C}_{20} \mathrm{H}_{23} \mathrm{O}_{10} \mathrm{FNa}^{+}[\mathrm{M}+\mathrm{Na}]^{+}$, 465.1167; found, 465.1173; deviation: $-1.15 \mathrm{ppm}$.

\section{1-Bromo-2-fluorobenzene (9)}

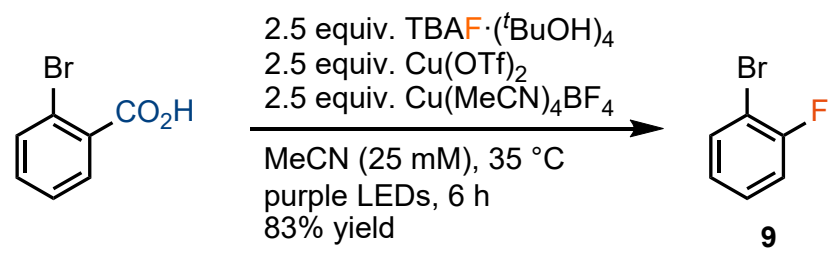

In a nitrogen-filled glovebox, a $16 \mathrm{~mL}$ borosilicate vial equipped with a magnetic stir bar was charged with 2bromobenzoic acid (40.2 mg, $0.200 \mathrm{mmol}, 1.00$ equiv.), Cu(OTf)2 (181 mg, $0.500 \mathrm{mmol}, 2.50$ equiv.), $\mathrm{Cu}(\mathrm{MeCN})_{4} \mathrm{BF}_{4}$ (157 mg, $0.500 \mathrm{mmol}, 2.50$ equiv.), and TBAF·( $\left.{ }^{\mathrm{B} u O H}\right)_{4}(279 \mathrm{mg}, 0.500 \mathrm{mmol}, 2.50$ equiv.). $\operatorname{MeCN}(8.0 \mathrm{~mL}, \mathrm{c}=25 \mathrm{mM})$ was then added into the vial. The vial was sealed with a Teflon cap, taken out of the glovebox and placed $5 \mathrm{~cm}$ away from two purple LEDs (Kessil PR160-390 $\mathrm{mm}$ LEDs). The reaction mixture was stirred without irradiation for $30 \mathrm{~min}$ at ambient temperature and then irradiated for $6 \mathrm{~h}$ while maintaining the temperature at approximately $35^{\circ} \mathrm{C}$ through cooling with a fan. After being irradiated for $6 \mathrm{~h}$, the reaction mixture was cooled to room temperature. 2-fluorotoluene (22.0 mg, $22.0 \mu \mathrm{L}, 0.200 \mathrm{mmol}, 1.00$ equiv.) was added as an internal standard. The reaction mixture was diluted with $\mathrm{CD}_{3} \mathrm{CN}$, and the yield of 1-bromo-2fluorobenzene (9) was determined by ${ }^{19} \mathrm{~F}$ NMR integration relative to the internal standard ( $85 \%$ yield, standard: $\delta-119.4(\mathrm{~m}) \mathrm{ppm}$, and 9: $\delta-109.4(\mathrm{~m}) \mathrm{ppm}$, Figure S8). The identity of the product was further confirmed by GCMS analysis (Figure S9).

The yield of 5 reported in the manuscript (83\%) represents an average of two runs [85\% (above) and $81 \%]$.

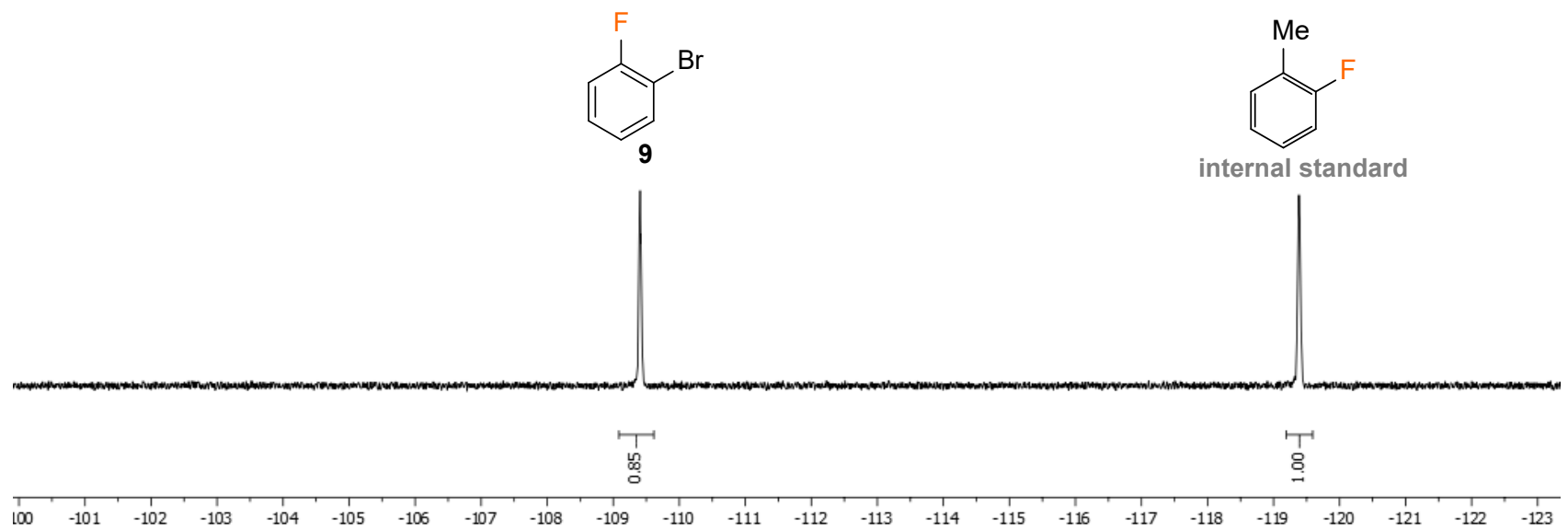

Figure S8. ${ }^{19} \mathrm{~F}$ NMR of resulting mixtures for product 9. 


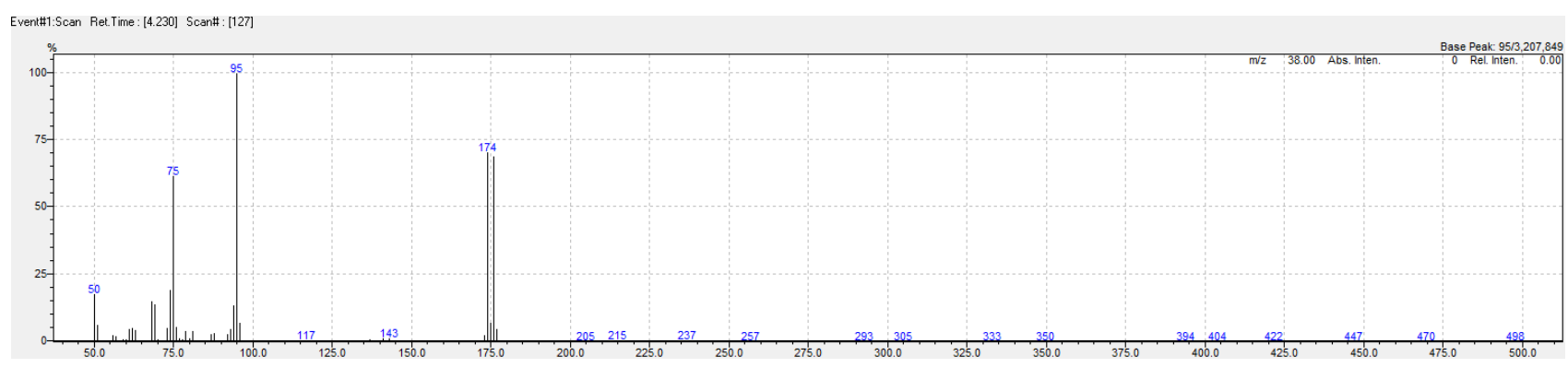

Figure S9. Mass spectrum of product 9 peak from GCMS.

\section{3-Fluoroanisole (10)}

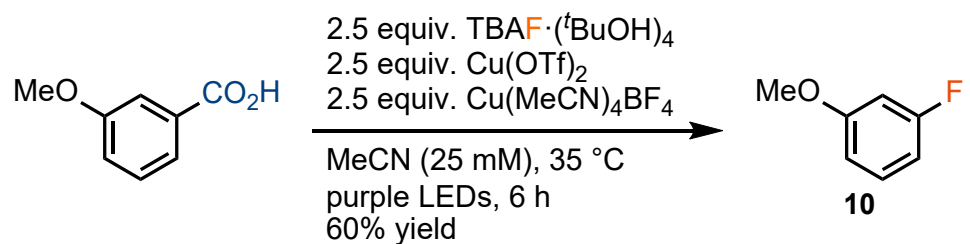

In a nitrogen-filled glovebox, a $16 \mathrm{~mL}$ borosilicate vial equipped with a magnetic stir bar was charged with 3methoxybenzoic acid (30.4 mg, $0.200 \mathrm{mmol}, 1.00$ equiv.), Cu(OTf) 2 (181 mg, $0.500 \mathrm{mmol}, 2.50$ equiv.), $\mathrm{Cu}(\mathrm{MeCN})_{4} \mathrm{BF}_{4}\left(157 \mathrm{mg}, 0.500 \mathrm{mmol}, 2.50\right.$ equiv.), and TBAF.('BuOH)${ }_{4}(279 \mathrm{mg}, 0.500 \mathrm{mmol}, 2.50$ equiv.). $\operatorname{MeCN}(8.0 \mathrm{~mL}, \mathrm{c}=25 \mathrm{mM})$ was then added into the vial. The vial was sealed with a Teflon cap, taken out of the glovebox and placed $5 \mathrm{~cm}$ away from two purple LEDs (Kessil PR160-390 nm LEDs). The reaction mixture was stirred without irradiation for $30 \mathrm{~min}$ at ambient temperature and then irradiated for $6 \mathrm{~h}$ while maintaining the temperature at approximately $35^{\circ} \mathrm{C}$ through cooling with a fan. After being irradiated for $6 \mathrm{~h}$, the reaction mixture was cooled to room temperature. 2-fluorotoluene $(22.0 \mathrm{mg}, 22.0 \mu \mathrm{L}, 0.200 \mathrm{mmol}, 1.00$ equiv.) was added as an internal standard. The reaction mixture was diluted with $\mathrm{CD}_{3} \mathrm{CN}$, and the yield of 3-fluoroanisole (10) was determined by ${ }^{19} \mathrm{~F}$ NMR integration relative to the internal standard (60\% yield, standard: $\delta-119.4$ (m) ppm, and 10: $\delta-113.6(\mathrm{~m}) \mathrm{ppm}$, Figure S10). The identity of the product was further confirmed by GCMS analysis (Figure S11).

The yield of 10 reported in the manuscript (60\%) represents an average of two runs [60\% (above) and $60 \%$ ]

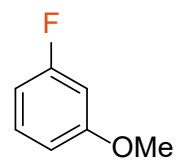

10

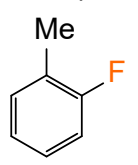

internal standard

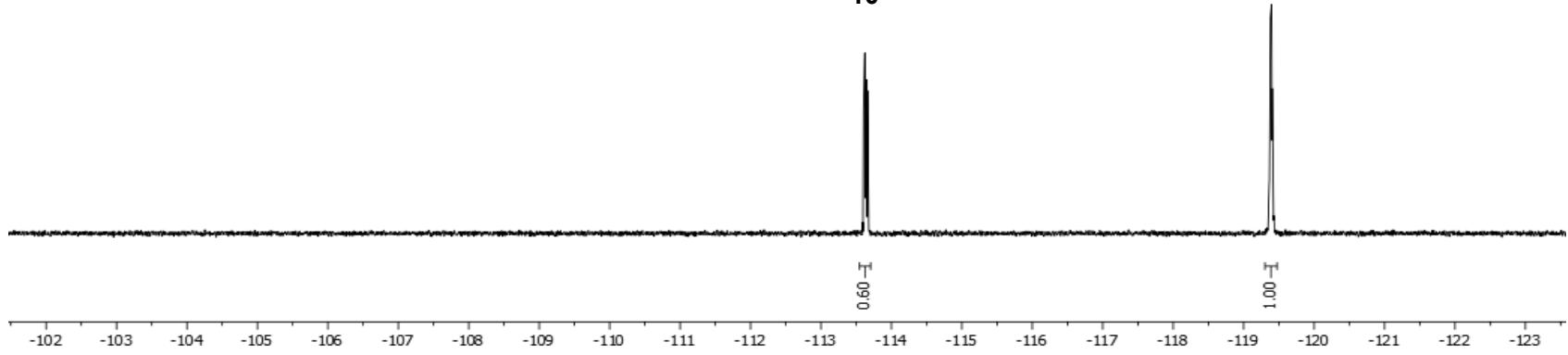

Figure S10. ${ }^{19} \mathrm{~F}$ NMR of resulting mixtures for product 10. 


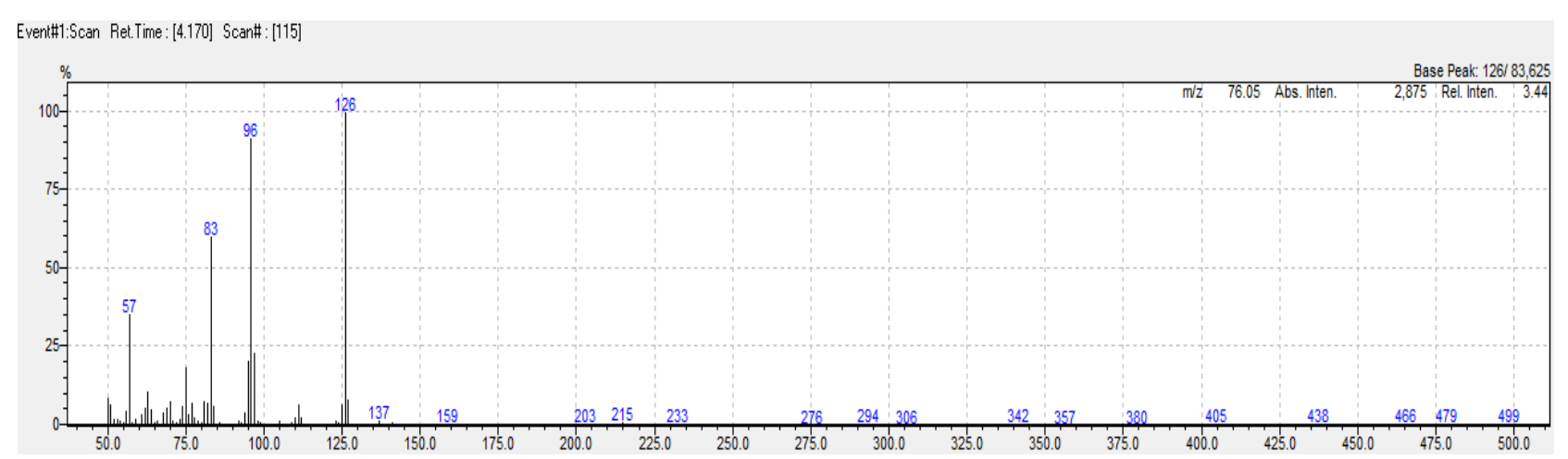

Figure S11. Mass spectrum of product 10 peak from GCMS

\section{2-Fluoroquinoxaline (11)}

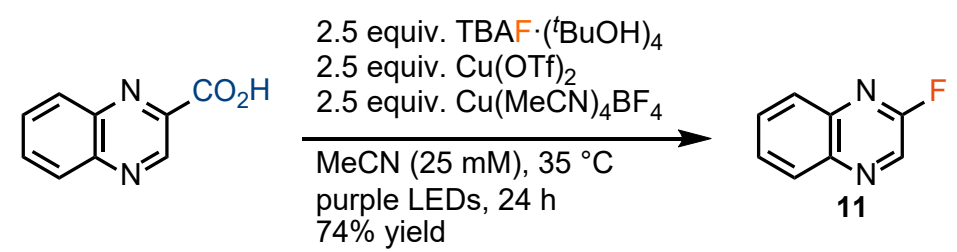

In a nitrogen-filled glovebox, a $16 \mathrm{~mL}$ borosilicate vial equipped with a magnetic stir bar was charged with quinoxaline-2-carboxylic acid (34.8 mg, $0.200 \mathrm{mmol}, 1.00$ equiv.), $\mathrm{Cu}(\mathrm{OTf})_{2}$ (181 mg, $0.500 \mathrm{mmol}, 2.50$ equiv.), $\mathrm{Cu}(\mathrm{MeCN})_{4} \mathrm{BF}_{4}(157 \mathrm{mg}, 0.500 \mathrm{mmol}, 2.50$ equiv.), and TBAF.('BuOH) 4 (279 mg, $0.500 \mathrm{mmol}, 2.50$ equiv.). $\operatorname{MeCN}(8.0 \mathrm{~mL}, \mathrm{c}=25 \mathrm{mM})$ was then added into the vial. The vial was sealed with a Teflon cap, taken out of the glovebox and placed $5 \mathrm{~cm}$ away from two purple LEDs (Kessil PR160-390 nm LEDs). The reaction mixture was stirred without irradiation for $30 \mathrm{~min}$ at ambient temperature and then irradiated for $24 \mathrm{~h}$ while maintaining the temperature at approximately $35^{\circ} \mathrm{C}$ through cooling with a fan. After being irradiated for $24 \mathrm{~h}$, the reaction mixture was cooled to room temperature. 2,6-difluoropyridine (11.5 mg, $9.1 \mu \mathrm{L}, 0.100 \mathrm{mmol}, 0.500$ equiv.) was added as an internal standard. The reaction mixture was diluted with $C_{3} C N$, and the yield of 2fluoroquinoxaline (11) was determined by ${ }^{19} \mathrm{~F}$ NMR integration relative to the internal standard $(74 \%$ yield, standard: $\delta-70.7(\mathrm{~s}) \mathrm{ppm}$, and 11: $\delta-76.3(\mathrm{~m}) \mathrm{ppm}$, Figure $\mathrm{S12}$ ). The identity of the product was further confirmed by GCMS analysis (Figure $\mathbf{S 1 3}$ ).

The yield of 11 reported in the manuscript (74\%) represents an average of two runs [74\% (above) and $74 \%]$

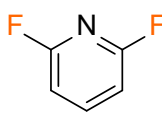

internal standard

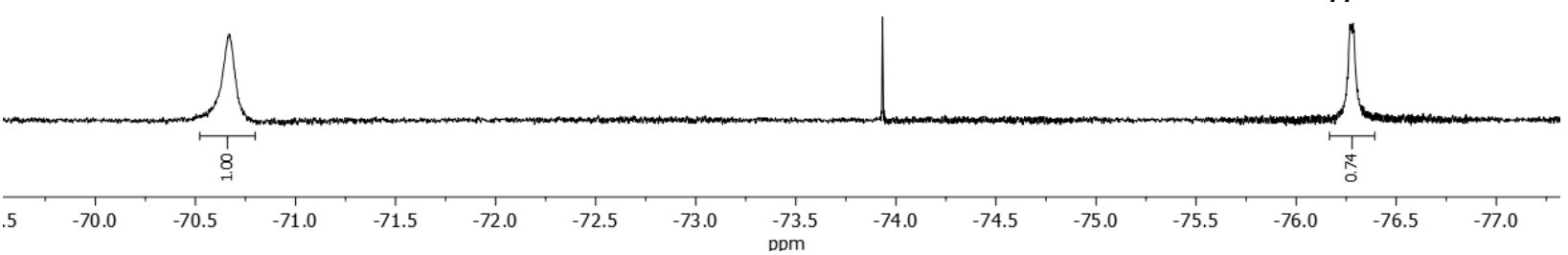

Figure S12. ${ }^{19} \mathrm{~F}$ NMR of resulting mixtures for product 11.

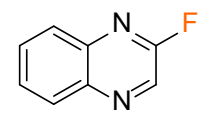

11 


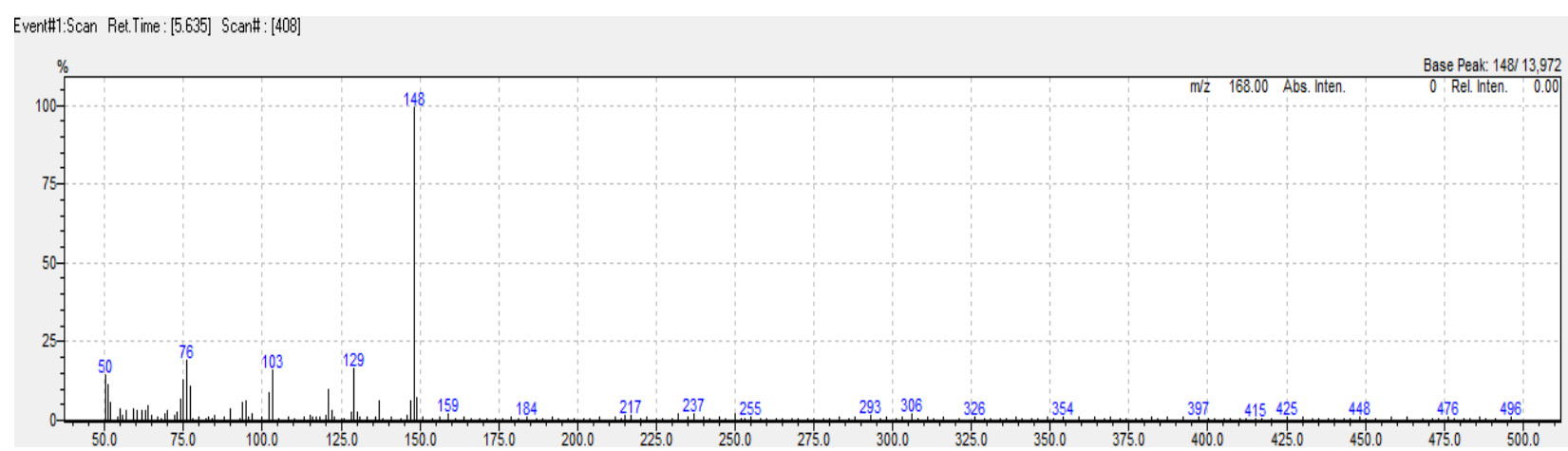

Figure S13. Mass spectrum of product 11 peak from GCMS

6-Fluoro-2-naphthonitrile (12)

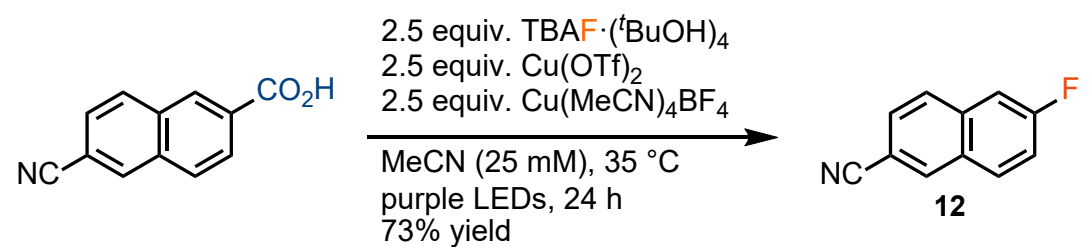

In a nitrogen-filled glovebox, a $16 \mathrm{~mL}$ borosilicate vial equipped with a magnetic stir bar was charged with 6cyano-2-naphthoic acid (39.4 mg, $0.200 \mathrm{mmol}, 1.00$ equiv.), Cu(OTf)2 (181 mg, $0.500 \mathrm{mmol}, 2.50$ equiv.), $\mathrm{Cu}(\mathrm{MeCN})_{4} \mathrm{BF}_{4}$ (157 mg, $0.500 \mathrm{mmol}, 2.50$ equiv.), and TBAF.('BuOH)4 $(279 \mathrm{mg}, 0.500 \mathrm{mmol}, 2.50$ equiv.). $\operatorname{MeCN}(8.0 \mathrm{~mL}, \mathrm{c}=25 \mathrm{mM})$ was then added into the vial. The vial was sealed with a Teflon cap, taken out of the glovebox and placed $5 \mathrm{~cm}$ away from two purple LEDs (Kessil PR160-390 nm LEDs). The reaction mixture was stirred without irradiation for $30 \mathrm{~min}$ at ambient temperature and then irradiated for $24 \mathrm{~h}$ while maintaining the temperature at approximately $35^{\circ} \mathrm{C}$ through cooling with a fan. After irradiation, the reaction mixture was transferred to a $25 \mathrm{~mL}$ round-bottom flask and evaporated to dryness. The desidue was dissolved in DCM (20 $\mathrm{mL}$ ), transferred into a separatory funnel containing $5 \mathrm{~mL}$ saturated aqueous $\mathrm{NH}_{4} \mathrm{Cl}$ and $5 \mathrm{~mL} \mathrm{H}_{2} \mathrm{O}$, and the layers were separated. The organic layer was collected, and the aqueous layer was further extracted with DCM $\left(3 \times\right.$ ca. $20 \mathrm{~mL}$ ). The combined organic layer was dried over $\mathrm{Na}_{2} \mathrm{SO}_{4}$, filtered, and the solvent was removed under reduced pressure. The residue was purified by chromatography on silica gel (pentane/DCM/EA $=30 / 1 / 1$, $\mathrm{v} / \mathrm{v}$ ) to afford 6-fluoro-2-naphthonitrile (12) $(25.1 \mathrm{mg}, 147 \mu \mathrm{mol}, 73 \%)$ as a colorless solid.

$\mathbf{R} \boldsymbol{f}=0.31($ hexanes/DCM, 1/2, v/v).

\section{NMR Spectroscopy:}

${ }^{1} \mathrm{H}$ NMR $\left(500 \mathrm{MHz}, \mathrm{CDCl}_{3}, 298 \mathrm{~K}, \delta\right): 8.23(\mathrm{~s}, 1 \mathrm{H}), 7.91(\mathrm{dd}, J=9.0,5.5 \mathrm{~Hz}, 1 \mathrm{H}), 7.87(\mathrm{~d}, J=8.5 \mathrm{~Hz}, 1 \mathrm{H})$, $7.63(\mathrm{dd}, J=8.6,1.7 \mathrm{~Hz}, 1 \mathrm{H}), 7.51(\mathrm{dd}, J=9.4,2.6 \mathrm{~Hz}, 1 \mathrm{H}), 7.39(\mathrm{td}, J=8.7,2.6 \mathrm{~Hz}, 1 \mathrm{H}) \mathrm{ppm}$.

${ }^{13} \mathrm{C}$ NMR $\left(126 \mathrm{MHz}, \mathrm{CDCl}_{3}, 298 \mathrm{~K}, \delta\right): 162.5(\mathrm{~d}, J=252.1 \mathrm{~Hz}), 135.9(\mathrm{~d}, J=10.1 \mathrm{~Hz}), 134.2,131.3(\mathrm{~d}, J$ $=9.5 \mathrm{~Hz}$ ), 129.4, 128.7 (d, J = 5.5 Hz), 127.6, 119.1, 118.5 (d, $J=25.7 \mathrm{~Hz}), 111.6$ (d, J = 21.3 Hz), 109.0 $(\mathrm{d}, J=2.9 \mathrm{~Hz}) \mathrm{ppm}$.

${ }^{19} \mathrm{~F} \mathrm{NMR}\left(471 \mathrm{MHz}, \mathrm{CDCl}_{3}, 298 \mathrm{~K}, \delta\right):-108.8(\mathrm{td}, J=8.9,5.5 \mathrm{~Hz}) \mathrm{ppm}$. 
HRMS-El (m/z) calculated for $\mathrm{C}_{11} \mathrm{H}_{6} \mathrm{NF}^{+}[\mathrm{M}]^{+}, 171.0479$; found, 171.0480; deviation: $-0.49 \mathrm{ppm}$.

5-(2-Fluorophenyl)-3-(3-fluorophenyl)-1,2,4-oxadiazole (13)
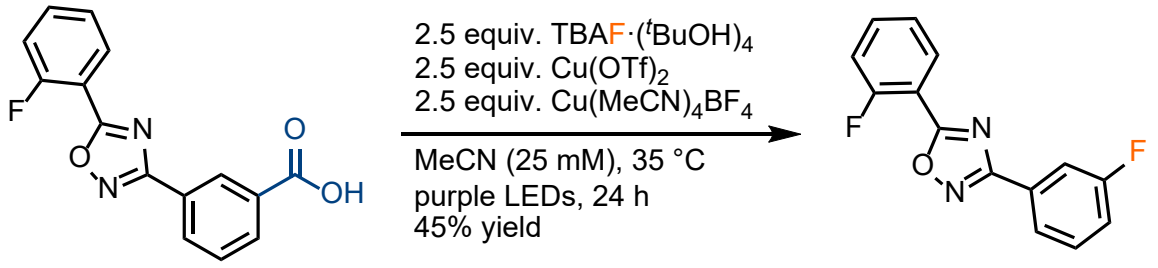

13

In a nitrogen-filled glovebox, a $16 \mathrm{~mL}$ borosilicate vial equipped with a magnetic stir bar was charged with ataluren (56.8 mg, $0.200 \mathrm{mmol}, 1.00$ equiv.), $\mathrm{Cu}(\mathrm{OTf})_{2}\left(181 \mathrm{mg}, 0.500 \mathrm{mmol}, 2.50\right.$ equiv.), $\mathrm{Cu}(\mathrm{MeCN})_{4} \mathrm{BF}_{4}(157$ $\mathrm{mg}, 0.500 \mathrm{mmol}, 2.50$ equiv.), and TBAF·( $\left.{ }^{(} \mathrm{BuOH}\right)_{4}(279 \mathrm{mg}, 0.500 \mathrm{mmol}, 2.50$ equiv. $)$. MeCN (8.0 mL, c = 25 $\mathrm{mM}$ ) was then added into the vial. The vial was sealed with a Teflon cap, taken out of the glovebox and placed $5 \mathrm{~cm}$ away from two purple LEDs (Kessil PR160-390 nm LEDs). The reaction mixture was stirred without irradiation for $30 \mathrm{~min}$ at ambient temperature and then irradiated for $24 \mathrm{~h}$ while maintaining the temperature at approximately $35{ }^{\circ} \mathrm{C}$ through cooling with a fan. After irradiation, the reaction mixture was transferred to a 25 $\mathrm{mL}$ round-bottom flask and evaporated to dryness. The desidue was dissolved in DCM $(20 \mathrm{~mL})$, transferred into a separatory funnel containing $5 \mathrm{~mL}$ saturated aqueous $\mathrm{NH}_{4} \mathrm{Cl}$ and $5 \mathrm{~mL} \mathrm{H} \mathrm{H}_{2} \mathrm{O}$, and the layers were separated. The organic layer was collected, and the aqueous layer was further extracted with DCM $(3 \times$ ca. 20 $\mathrm{mL}$ ). The combined organic layer was dried over $\mathrm{Na}_{2} \mathrm{SO}_{4}$, filtered, and the solvent was removed under reduced pressure. The residue was purified by chromatography on silica gel $(D C M /$ hexanes $=1 / 2, v / v)$ to yield a mixture. The mixture was then purified by preparative TLC (DCM/ hexanes = 1/2, v/v) to afford 5-(2-fluorophenyl)-3-(3fluorophenyl)-1,2,4-oxadiazole (13) (23.3 mg, $90.2 \mu \mathrm{mol}, 45 \%)$ as a colorless solid.

$\boldsymbol{R} \boldsymbol{f}=0.31(\mathrm{DCM} / \mathrm{hexanes}=1 / 2, \mathrm{v} / \mathrm{v})$.

\section{NMR Spectroscopy:}

${ }^{1} \mathrm{H}$ NMR $\left(500 \mathrm{MHz}, \mathrm{CDCl}_{3}, 298 \mathrm{~K}, \delta\right): 8.27-8.16(\mathrm{~m}, 1 \mathrm{H}), 7.98(\mathrm{~d}, J=7.9 \mathrm{~Hz}, 1 \mathrm{H}), 7.88(\mathrm{~d}, J=9.9 \mathrm{~Hz}, 1 \mathrm{H})$, 7.65-7.56 (m, 1H), 7.48 (tdd, $J=8.3,5.5,2.9 \mathrm{~Hz}, 1 \mathrm{H}), 7.34$ (td, $J=7.6,2.5 \mathrm{~Hz}, 1 \mathrm{H}), 7.28$ (ddd, $J=10.9$, 8.1, $2.7 \mathrm{~Hz}, 1 \mathrm{H}), 7.22(\mathrm{td}, J=8.4,4.2 \mathrm{~Hz}, 1 \mathrm{H}) \mathrm{ppm}$.

${ }^{13} \mathrm{C}$ NMR (126 MHz, $\left.\mathrm{CDCl}_{3}, 298 \mathrm{~K}, \delta\right): 173.1$ (d, J = 4.4 Hz), 167.9 (d, J = 3.1 Hz), 163.0 (d, J = 246.6 Hz), 160.9 (d, $J=261.0 \mathrm{~Hz}), 134.8$ (d, $J=8.6 \mathrm{~Hz}), 131.0,130.7$ (d, J = 8.2 Hz), 128.9 (d, J = 8.5 Hz), 124.8 (d, $J=4.0 \mathrm{~Hz}), 123.4(\mathrm{~d}, J=3.1 \mathrm{~Hz}), 118.3(\mathrm{~d}, J=21.1 \mathrm{~Hz}), 117.3(\mathrm{~d}, J=20.9 \mathrm{~Hz}), 114.7$ (d, $J=23.5 \mathrm{~Hz})$, $112.8(\mathrm{~d}, J=11.2 \mathrm{~Hz}) \mathrm{ppm}$.

${ }^{19} \mathrm{~F}$ NMR (471 MHz, $\left.\mathrm{CDCl}_{3}, 298 \mathrm{~K}, \delta\right):-108.2(\mathrm{~m}),-111.9(\mathrm{td}, J=9.3,5.9 \mathrm{~Hz}) \mathrm{ppm}$.

HRMS-El (m/z) calculated for $\mathrm{C}_{14} \mathrm{H}_{8} \mathrm{~N}_{2} \mathrm{OF}_{2}{ }^{+}[\mathrm{M}]^{+}$, 258.0599; found, 258.0604; deviation: -1.94 ppm. 
4-Fluorophenyl methyl sulfone (14)

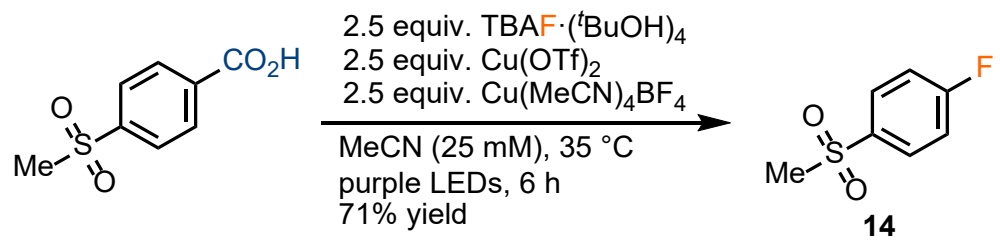

In a nitrogen-filled glovebox, a $16 \mathrm{~mL}$ borosilicate vial equipped with a magnetic stir bar was charged with 4(methylsulfonyl)benzoic acid (40.0 mg, $0.200 \mathrm{mmol}, 1.00$ equiv.), Cu(OTf) 2 (181 mg, 0.500 mmol, 2.50 equiv.), $\mathrm{Cu}(\mathrm{MeCN})_{4} \mathrm{BF}_{4}(157 \mathrm{mg}, 0.500 \mathrm{mmol}, 2.50$ equiv.), and TBAF.('BuOH) 4 (279 mg, $0.500 \mathrm{mmol}, 2.50$ equiv.). $\operatorname{MeCN}(8.0 \mathrm{~mL}, \mathrm{c}=25 \mathrm{mM})$ was then added into the vial. The vial was sealed with a Teflon cap, taken out of the glovebox and placed $5 \mathrm{~cm}$ away from two purple LEDs (Kessil PR160-390 nm LEDs). The reaction mixture was stirred without irradiation for $30 \mathrm{~min}$ at ambient temperature and then irradiated for $6 \mathrm{~h}$ while maintaining the temperature at approximately $35^{\circ} \mathrm{C}$ through cooling with a fan. After irradiation, the reaction mixture was transferred to a $25 \mathrm{~mL}$ round-bottom flask and evaporated to dryness. The desidue was dissolved in DCM (20 $\mathrm{mL}$ ), transferred into a separatory funnel containing $5 \mathrm{~mL}$ saturated aqueous $\mathrm{NH}_{4} \mathrm{Cl}$ and $5 \mathrm{~mL} \mathrm{H}_{2} \mathrm{O}$, and the layers were separated. The organic layer was collected, and the aqueous layer was further extracted with DCM $(3 \times$ ca. $20 \mathrm{~mL})$. The combined organic layer was dried over $\mathrm{Na}_{2} \mathrm{SO}_{4}$, filtered, and the solvent was removed under reduced pressure. The residue was purified by chromatography on silica gel $(E A / D C M=1 / 50, v / v)$ to afford 4-fluorophenyl methyl sulfone (14) $(24.9 \mathrm{mg}, 143 \mu \mathrm{mol}, 71 \%)$ as a slightly yellow solid.

$\mathbf{R f}=0.50(\mathrm{DCM} / \mathrm{EA}=20 / 1, \mathrm{v} / \mathrm{v})$.

\section{NMR Spectroscopy:}

${ }^{1} \mathrm{H}$ NMR (500 MHz, $\left.\mathrm{CDCl}_{3}, 298 \mathrm{~K}, \delta\right): 7.97$ (dd, J = 8.6, $\left.5.2 \mathrm{~Hz}, 2 \mathrm{H}\right), 7.25$ (t, J = 8.3 Hz, 2H), 3.06 (s, 3H) ppm.

${ }^{13} \mathrm{C}$ NMR (126 MHz, $\left.\mathrm{CDCl}_{3}, 298 \mathrm{~K}, \delta\right): 165.9$ (d, J = 256.3 Hz), 136.8 (d, J = 3.3 Hz), 130.4 (d, J = 9.5 Hz), $116.8(\mathrm{~d}, \mathrm{~J}=22.7 \mathrm{~Hz}), 44.8 \mathrm{ppm}$.

${ }^{19} \mathrm{~F}$ NMR $\left(471 \mathrm{MHz}, \mathrm{CDCl}_{3}, 298 \mathrm{~K}, \delta\right):-103.5(\mathrm{tt}, J=8.8,5.0 \mathrm{~Hz}) \mathrm{ppm}$.

HRMS-El (m/z) calculated for $\mathrm{C}_{7} \mathrm{H}_{7} \mathrm{O}_{2} \mathrm{SF}^{+}[\mathrm{M}]^{+}, 174.0145$; found, 174.0147; deviation: -0.91 ppm.

\section{3-Fluorobenzaldehyde (15)}

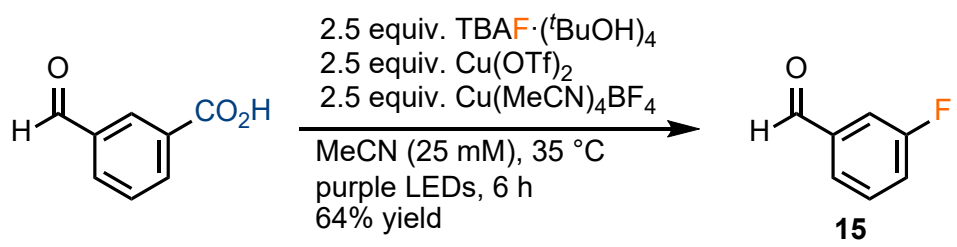

In a nitrogen-filled glovebox, a $16 \mathrm{~mL}$ borosilicate vial equipped with a magnetic stir bar was charged with 3formylbenzoic acid (30.0 mg, $0.200 \mathrm{mmol}, 1.00$ equiv.), Cu(OTf)2 (181 mg, $0.500 \mathrm{mmol}, 2.50$ equiv.), $\mathrm{Cu}(\mathrm{MeCN})_{4} \mathrm{BF}_{4}$ (157 mg, $0.500 \mathrm{mmol}, 2.50$ equiv.), and TBAF·( $\left.{ }^{\mathrm{B} u O H}\right)_{4}(279 \mathrm{mg}, 0.500 \mathrm{mmol}, 2.50$ equiv.). 
$\operatorname{MeCN}(8.0 \mathrm{~mL}, \mathrm{c}=25 \mathrm{mM}$ ) was then added into the vial. The vial was sealed with a Teflon cap, taken out of the glovebox and placed $5 \mathrm{~cm}$ away from two purple LEDs (Kessil PR160-390 nm LEDs). The reaction mixture was stirred without irradiation for $30 \mathrm{~min}$ at ambient temperature and then irradiated for $6 \mathrm{~h}$ while maintaining the temperature at approximately $35^{\circ} \mathrm{C}$ through cooling with a fan. After being irradiated for $6 \mathrm{~h}$, the reaction mixture was cooled to room temperature. 2-fluorotoluene $(22.0 \mathrm{mg}, 22.0 \mu \mathrm{L}, 0.200 \mathrm{mmol}, 1.00$ equiv.) was added as an internal standard. The reaction mixture was diluted with $\mathrm{CD}_{3} \mathrm{CN}$, and the yield of 3fluorobenzaldehyde (15) was determined by ${ }^{19} \mathrm{~F}$ NMR integration relative to the internal standard $(65 \%$ yield, standard: $\delta-119.4(\mathrm{~m}) \mathrm{ppm}$, and 15: $\delta-113.6(\mathrm{~m}) \mathrm{ppm}$, Figure S14). The identity of the product was further confirmed by GCMS analysis (Figure $\mathbf{S 1 5}$ ).

The yield of 15 reported in the manuscript (64\%) represents an average of two runs [65\% (above) and 63\%]

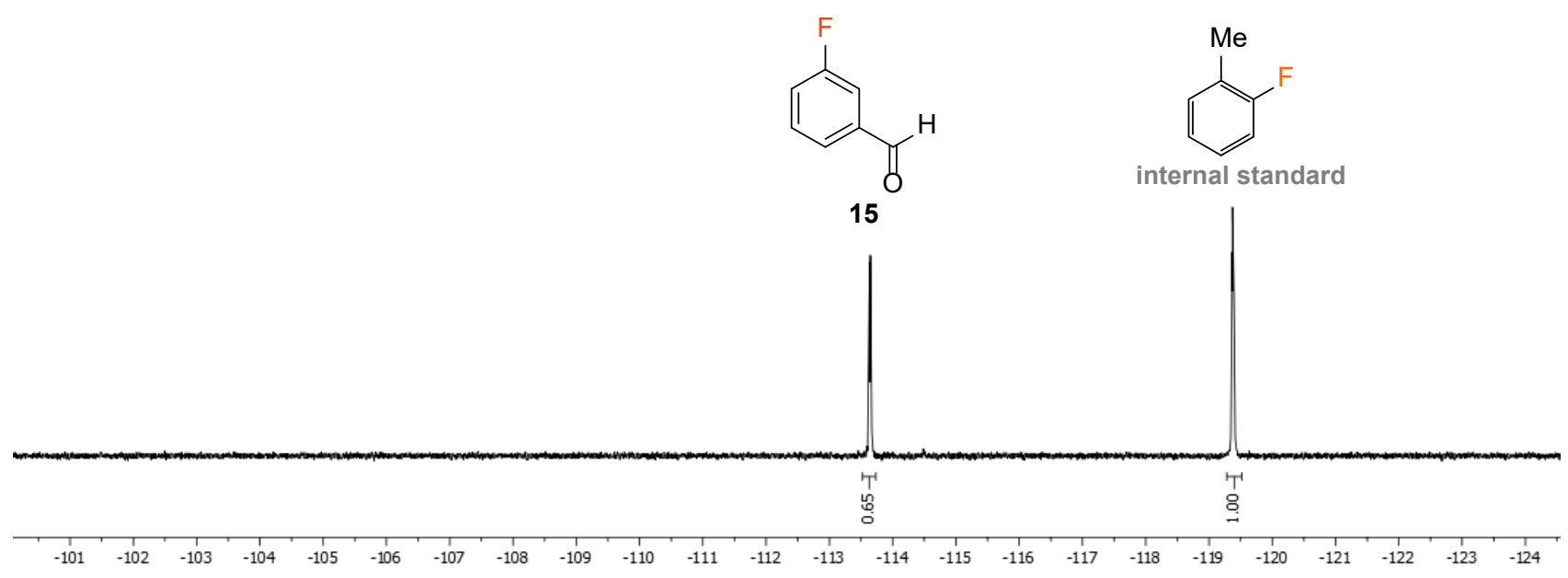

Figure S14. ${ }^{19} \mathrm{~F}$ NMR of resulting mixtures for product 15.

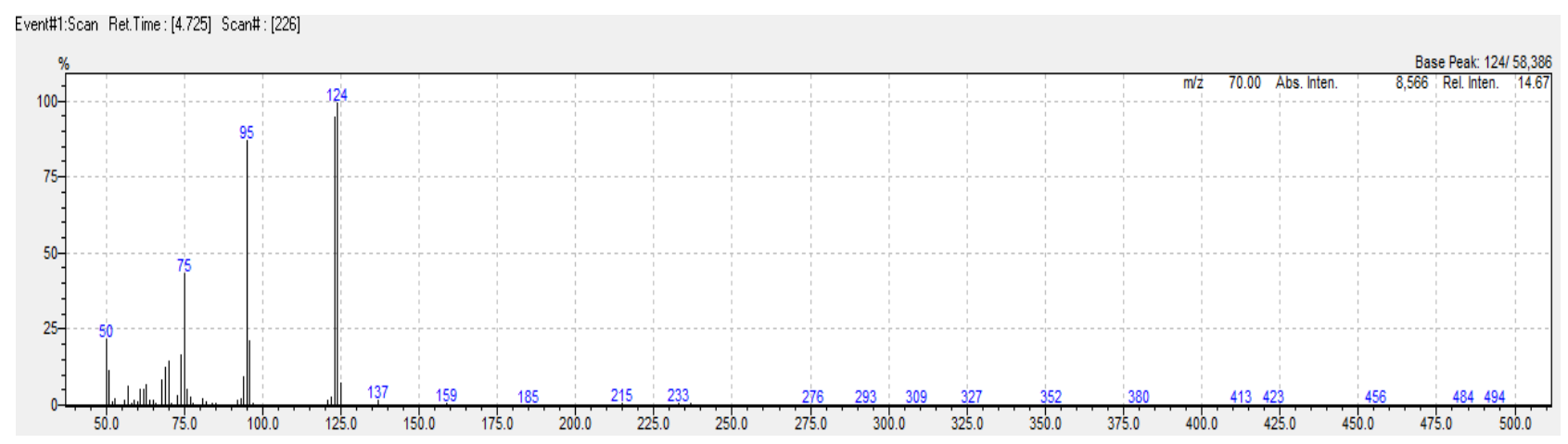

Figure S15. Mass spectrum of product 15 peak from GCMS 
6-Fluoro-1-tetralone (16)<smiles>O=C(O)c1ccc2c(c1)CCCC2=O</smiles>

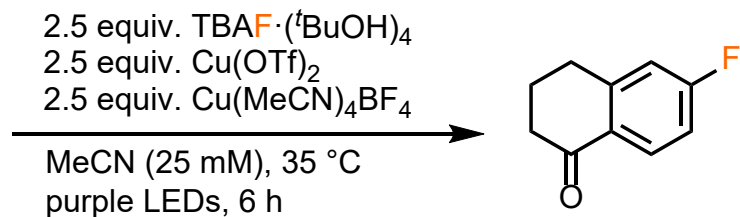

16

In a nitrogen-filled glovebox, a $16 \mathrm{~mL}$ borosilicate vial equipped with a magnetic stir bar was charged with 6carboxy-1-tetralone (38.0 mg, $0.200 \mathrm{mmol}, 1.00$ equiv.), $\mathrm{Cu}(\mathrm{OTf})_{2}$ (181 mg, $0.500 \mathrm{mmol}, 2.50$ equiv.), $\mathrm{Cu}(\mathrm{MeCN})_{4} \mathrm{BF}_{4}$ (157 mg, $0.500 \mathrm{mmol}, 2.50$ equiv.), and TBAF·( $\left.{ }^{\mathrm{B}} \mathrm{BuOH}\right)_{4}(279 \mathrm{mg}, 0.500 \mathrm{mmol}, 2.50$ equiv.). $\operatorname{MeCN}(8.0 \mathrm{~mL}, \mathrm{c}=25 \mathrm{mM})$ was then added into the vial. The vial was sealed with a Teflon cap, taken out of the glovebox and placed $5 \mathrm{~cm}$ away from two purple LEDs (Kessil PR160-390 nm LEDs). The reaction mixture was stirred without irradiation for $30 \mathrm{~min}$ at ambient temperature and then irradiated for $6 \mathrm{~h}$ while maintaining the temperature at approximately $35^{\circ} \mathrm{C}$ through cooling with a fan. After irradiation, the reaction mixture was transferred to a $25 \mathrm{~mL}$ round-bottom flask and evaporated to dryness. The desidue was dissolved in DCM (20 $\mathrm{mL}$ ), transferred into a separatory funnel containing $5 \mathrm{~mL}$ saturated aqueous $\mathrm{NH}_{4} \mathrm{Cl}$ and $5 \mathrm{~mL} \mathrm{H}_{2} \mathrm{O}$, and the layers were separated. The organic layer was collected, and the aqueous layer was further extracted with DCM $(3 \times$ ca. $20 \mathrm{~mL})$. The combined organic layer was dried over $\mathrm{Na}_{2} \mathrm{SO}_{4}$, filtered, and the solvent was removed under reduced pressure. The residue was purified by chromatography on silica gel (pentane/EA $=40 / 1, v / v)$ to afford 6-fluoro-1-tetralone (16) (23.0 mg, $140 \mu \mathrm{mol}, 70 \%)$ as a colorless oil.

$\mathbf{R} \boldsymbol{f}=0.20($ pentane/EA $=20 / 1, \mathrm{v} / \mathrm{v})$.

\section{NMR Spectroscopy:}

${ }^{1} \mathrm{H}$ NMR $\left(500 \mathrm{MHz}, \mathrm{CDCl}_{3}, 298 \mathrm{~K}, \delta\right): 8.06(\mathrm{dd}, J=8.7,6.0 \mathrm{~Hz}, 1 \mathrm{H}), 6.98(\mathrm{td}, J=8.5,2.6 \mathrm{~Hz}, 1 \mathrm{H}), 6.93$ (dd, $J=9.1,2.6 \mathrm{~Hz}, 1 \mathrm{H}), 2.96(\mathrm{t}, J=6.1 \mathrm{~Hz}, 2 \mathrm{H}), 2.64$ (dd, $J=7.3,5.8 \mathrm{~Hz}, 2 \mathrm{H}), 2.14(\mathrm{p}, J=6.4 \mathrm{~Hz}, 2 \mathrm{H})$ ppm.

${ }^{13} \mathrm{C}$ NMR (126 MHz, $\left.\mathrm{CDCl}_{3}, 298 \mathrm{~K}, \delta\right): 197.0,165.8$ (d, $\left.J=255.2 \mathrm{~Hz}\right), 147.6$ (d, $\left.J=8.9 \mathrm{~Hz}\right), 130.5$ (d, $J=$ 10.0 Hz), 129.4 (d, $J=2.9 \mathrm{~Hz}), 115.2$ (d, $J=21.3 \mathrm{~Hz}), 114.4$ (d, $J=21.6 \mathrm{~Hz}), 39.0,30.0,23.3 \mathrm{ppm}$.

${ }^{19} \mathrm{~F}$ NMR $\left(471 \mathrm{MHz}, \mathrm{CDCl}_{3}, 298 \mathrm{~K}, \delta\right):-104.8(\mathrm{td}, J=8.6,5.9 \mathrm{~Hz}) \mathrm{ppm}$.

HRMS-El (m/z) calculated for $\mathrm{C}_{10} \mathrm{H}_{9} \mathrm{OF}^{+}[\mathrm{M}]^{+}, 164.0632$; found, 164.0634; deviation: -1.32 ppm.

$1 \mathrm{mmol}$ scale decarboxylative fluorination of 6-carboxy-1-tetralone:
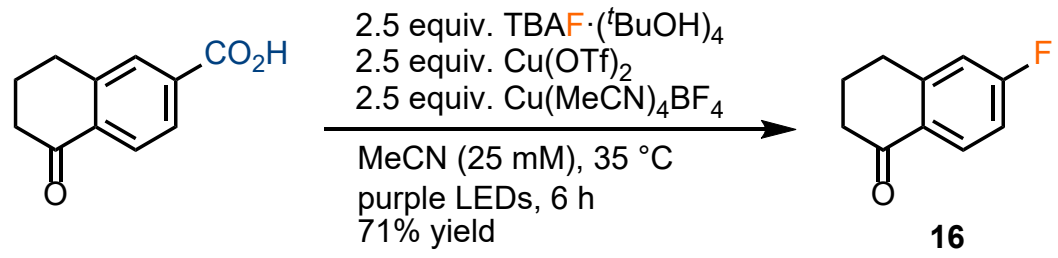

In a nitrogen-filled glovebox, a $100 \mathrm{~mL}$ Schlenk tube equipped with a magnetic stir bar was charged with 6- 
carboxy-1-tetralone (190 mg, $1.00 \mathrm{mmol}, 1.00$ equiv.), Cu(OTf)2 (904 mg, $2.50 \mathrm{mmol}, 2.50$ equiv.), $\mathrm{Cu}(\mathrm{MeCN})_{4} \mathrm{BF}_{4}$ (786 mg, $2.50 \mathrm{mmol}, 2.50$ equiv.), and TBAF·('BuOH) ${ }_{4}(1.39 \mathrm{~g}, 2.50 \mathrm{mmol}, 2.50$ equiv.). MeCN ( $40 \mathrm{~mL}, \mathrm{c}=25 \mathrm{mM}$ ) was then added into the tube. The tube was sealed with a rubber stopper, taken out of the glovebox and placed $5 \mathrm{~cm}$ away from two purple LEDs (Kessil PR160-390 nm LEDs). The reaction mixture was stirred without irradiation for $30 \mathrm{~min}$ at ambient temperature and then irradiated for $6 \mathrm{~h}$ while maintaining the temperature at approximately $35^{\circ} \mathrm{C}$ through cooling with a fan. After irradiation, the reaction mixture was transferred to a $100 \mathrm{~mL}$ round-bottom flask and evaporated to dryness. The residue was dissolved in DCM (30 $\mathrm{mL}$ ), transferred into a separatory funnel containing $15 \mathrm{~mL}$ saturated aqueous $\mathrm{NH}_{4} \mathrm{Cl}$ and $15 \mathrm{~mL} \mathrm{H}_{2} \mathrm{O}$, and the layers were separated. The organic layer was collected, and the aqueous layer was further extracted with DCM $\left(3 \times\right.$ ca. $30 \mathrm{~mL}$ ). The combined organic layer was dried over $\mathrm{Na}_{2} \mathrm{SO}_{4}$, filtered, and the solvent was removed under reduced pressure. The residue was purified by chromatography on silica gel (pentane/EA $=40 / 1, v / v)$ to afford 6-fluoro-1-tetralone (117 mg, $713 \mu \mathrm{mol}, 71 \%$ ) as a colorless oil.

\section{2,2'-(5-Fluoro-1,3-phenylene)bis(2-methylpropanenitrile) (17)}

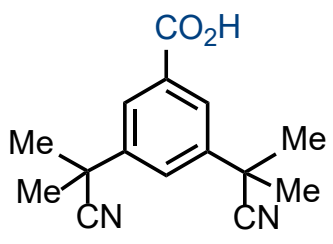

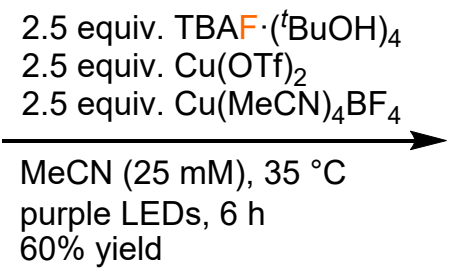

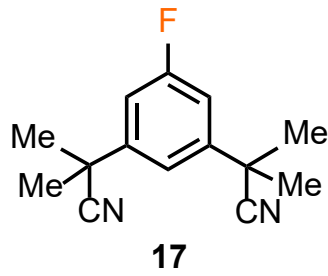

17

In a nitrogen-filled glovebox, a $16 \mathrm{~mL}$ borosilicate vial equipped with a magnetic stir bar was charged with 3,5bis(2-cyanopropan-2-yl)benzoic acid (51.3 mg, $0.200 \mathrm{mmol}, 1.00$ equiv.), Cu(OTf)2 (181 mg, $0.500 \mathrm{mmol}, 2.50$ equiv.), $\mathrm{Cu}(\mathrm{MeCN})_{4} \mathrm{BF}_{4}$ (157 mg, $0.500 \mathrm{mmol}, 2.50$ equiv.), and TBAF.( $\left.{ }^{\mathrm{BuOH}}\right)_{4}(279 \mathrm{mg}, 0.500 \mathrm{mmol}, 2.50$ equiv.). $\mathrm{MeCN}(8.0 \mathrm{~mL}, \mathrm{c}=25 \mathrm{mM}$ ) was then added into the vial. The vial was sealed with a Teflon cap, taken out of the glovebox and placed $5 \mathrm{~cm}$ away from two purple LEDs (Kessil PR160-390 nm LEDs). The reaction mixture was stirred without irradiation for $30 \mathrm{~min}$ at ambient temperature and then irradiated for $6 \mathrm{~h}$ while maintaining the temperature at approximately $35^{\circ} \mathrm{C}$ through cooling with a fan. After irradiation, the reaction mixture was transferred to a $25 \mathrm{~mL}$ round-bottom flask and evaporated to dryness. The desidue was dissolved in $\mathrm{DCM}(20 \mathrm{~mL})$, transferred into a separatory funnel containing $5 \mathrm{~mL}$ saturated aqueous $\mathrm{NH}_{4} \mathrm{Cl}$ and $5 \mathrm{~mL} \mathrm{H}_{2} \mathrm{O}$, and the layers were separated. The organic layer was collected, and the aqueous layer was further extracted with DCM ( $3 \times$ ca. $20 \mathrm{~mL}$ ). The combined organic layer was dried over $\mathrm{Na}_{2} \mathrm{SO}_{4}$, filtered, and the solvent was removed under reduced pressure. The residue was purified by chromatography on silica gel (DCM) to yield a mixture. The mixture was further purified by preparative HPLC (25.2 min, YMC-Actus Triart C18 (150 × 30.0 $\mathrm{mm}: 5 \mu \mathrm{m}+50 \times 30.0 \mathrm{~mm}: 5 \mu \mathrm{m}), \mathrm{MeCN} / \mathrm{H}_{2} \mathrm{O}=40 / 60$ to 50/50, v/v over $30 \mathrm{~min}, 42.5 \mathrm{~mL} / \mathrm{min}, 308 \mathrm{~K}, 254 \mathrm{~nm}$ ). The fraction was evaporated under vacuum to remove most of the $\mathrm{MeCN}$, and the remaining mixture was extracted with DCM $(3 \times$ ca. $50 \mathrm{~mL})$. The combined organic layer was dried over $\mathrm{Na}_{2} \mathrm{SO}_{4}$, filtered, and the solvent was removed under reduced pressure to afford 2,2'-(5-fluoro-1,3-phenylene)bis(2-methylpropanenitrile) (17) (27.5 mg, $119 \mu \mathrm{mol}, 60 \%)$ as a colorless solid.

$\mathbf{R f}=0.47(\mathrm{DCM})$. 


\section{NMR Spectroscopy:}

${ }^{1} \mathrm{H}$ NMR $\left(500 \mathrm{MHz}, \mathrm{CDCl}_{3}, 298 \mathrm{~K}, \delta\right): 7.38(\mathrm{t}, J=1.8 \mathrm{~Hz}, 1 \mathrm{H}), 7.14(\mathrm{dd}, J=9.3,1.7 \mathrm{~Hz}, 2 \mathrm{H}), 1.74(\mathrm{~s}, 12 \mathrm{H})$ ppm.

${ }^{13} \mathrm{C}$ NMR (126 MHz, $\left.\mathrm{CDCl}_{3}, 298 \mathrm{~K}, \delta\right): 163.2(\mathrm{~d}, J=248.6 \mathrm{~Hz}), 145.0(\mathrm{~d}, J=7.6 \mathrm{~Hz}), 123.8,117.8(\mathrm{~d}, J=$ $2.7 \mathrm{~Hz}), 112.3(\mathrm{~d}, J=23.2 \mathrm{~Hz}), 37.4(\mathrm{~d}, J=2.2 \mathrm{~Hz}), 29.1 \mathrm{ppm}$.

${ }^{19} \mathrm{~F}$ NMR $\left(471 \mathrm{MHz}, \mathrm{CDCl}_{3}, 298 \mathrm{~K}, \delta\right):-109.8(\mathrm{t}, \mathrm{J}=9.4 \mathrm{~Hz}) \mathrm{ppm}$.

HRMS-El (m/z) calculated for $\mathrm{C}_{14} \mathrm{H}_{15} \mathrm{~N}_{2} \mathrm{~F}^{+}[\mathrm{M}]^{+}, 230.1214$; found, 230.1219; deviation: -2.28 ppm.

\section{6-Fluorofluorescein diacetate (18)}

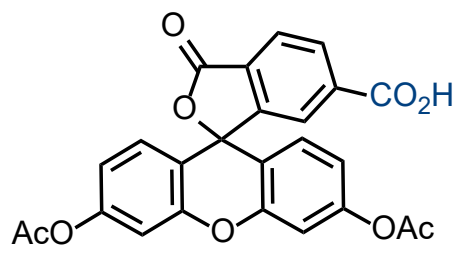

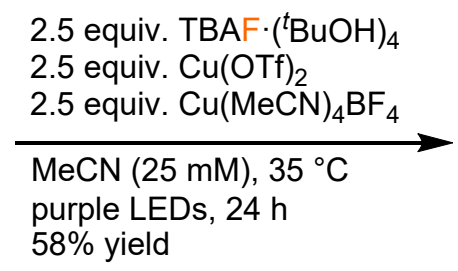

$58 \%$ yield

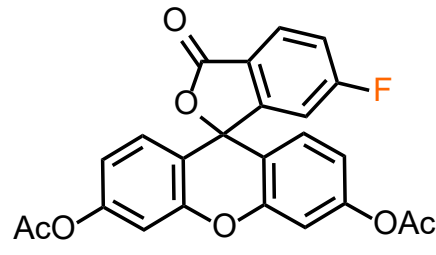

18

In a nitrogen-filled glovebox, a $16 \mathrm{~mL}$ borosilicate vial equipped with a magnetic stir bar was charged with 6carboxyfluorescein diacetate (92.1 mg, $0.200 \mathrm{mmol}, 1.00$ equiv.), Cu(OTf) 2 (181 mg, $0.500 \mathrm{mmol}, 2.50$ equiv.), $\mathrm{Cu}(\mathrm{MeCN})_{4} \mathrm{BF}_{4}$ (157 mg, $0.500 \mathrm{mmol}, 2.50$ equiv.), and TBAF·( $\left.{ }^{\mathrm{B} u O H}\right)_{4}(279 \mathrm{mg}, 0.500 \mathrm{mmol}, 2.50$ equiv.). $\operatorname{MeCN}(8.0 \mathrm{~mL}, \mathrm{c}=25 \mathrm{mM})$ was then added into the vial. The vial was sealed with a Teflon cap, taken out of the glovebox and placed $5 \mathrm{~cm}$ away from two purple LEDs (Kessil PR160-390 nm LEDs). The reaction mixture was stirred without irradiation for $30 \mathrm{~min}$ at ambient temperature and then irradiated for $24 \mathrm{~h}$ while maintaining the temperature at approximately $35^{\circ} \mathrm{C}$ through cooling with a fan. After irradiation, the reaction mixture was transferred to a $25 \mathrm{~mL}$ round-bottom flask and evaporated to dryness. The desidue was dissolved in DCM (20 $\mathrm{mL}$ ), transferred into a separatory funnel containing $5 \mathrm{~mL}$ saturated aqueous $\mathrm{NH}_{4} \mathrm{Cl}$ and $5 \mathrm{~mL} \mathrm{H}_{2} \mathrm{O}$, and the layers were separated. The organic layer was collected, and the aqueous layer was further extracted with DCM ( $3 \times$ ca. $20 \mathrm{~mL}$ ). The combined organic layer was dried over $\mathrm{Na}_{2} \mathrm{SO}_{4}$, filtered, and the solvent was removed under reduced pressure. The residue was directly purified by preparative HPLC (33.3 min, YMC-Actus Triart C18 $(150 \times 30.0 \mathrm{~mm}: 5 \mu \mathrm{m}+50 \times 30.0 \mathrm{~mm}: 5 \mu \mathrm{m}), \mathrm{MeCN} / \mathrm{H}_{2} \mathrm{O}=42 / 58$ to 47/53, v/v over $20 \mathrm{~min}, 42.5 \mathrm{~mL} / \mathrm{min}$, $308 \mathrm{~K}, 254 \mathrm{~nm}$ ) (Note: 6-fluorofluorescein diacetate (18) is not stable on silica gel). The fraction was evaporated under vacuum to remove most of the $\mathrm{MeCN}$, and the remaining mixture was extracted with $\mathrm{DCM}(3 \times$ ca. 50 $\mathrm{mL}$ ). The combined organic layer was dried over $\mathrm{Na}_{2} \mathrm{SO}_{4}$, filtered, and the solvent was removed under reduced pressure to afford 6-fluorofluorescein diacetate (18) $(50.4 \mathrm{mg}, 116 \mu \mathrm{mol}, 58 \%)$ as a slightly yellow solid.

$\mathbf{R} f=0.22(\mathrm{DCM})$

\section{NMR Spectroscopy:}

${ }^{1} \mathrm{H}$ NMR (500 MHz, $\left.\mathrm{CDCl}_{3}, 298 \mathrm{~K}, \delta\right): 8.03(\mathrm{dd}, J=8.5,4.7 \mathrm{~Hz}, 1 \mathrm{H}), 7.31$ (td, $\left.J=8.5,2.2 \mathrm{~Hz}, 1 \mathrm{H}\right), 7.10$ (dd, $J=1.9,0.8 \mathrm{~Hz}, 2 \mathrm{H}), 6.89-6.81(\mathrm{~m}, 5 \mathrm{H}), 2.31$ (s, 6H) ppm. 
${ }^{13} \mathrm{C}$ NMR (126 MHz, $\left.\mathrm{CDCl}_{3}, 298 \mathrm{~K}, \delta\right): 168.9,168.0,167.3$ (d, J = 258.6 Hz), 155.8 (d, J = 9.7 Hz), 152.3, 151.6, 128.9, 127.8 (d, $J=10.2 \mathrm{~Hz}), 122.2(\mathrm{~d}, J=1.7 \mathrm{~Hz}), 118.6(\mathrm{~d}, J=24.2 \mathrm{~Hz}), 118.0,115.9,111.4$ (d, $J=24.4 \mathrm{~Hz}), 110.6,81.1(\mathrm{~d}, J=2.7 \mathrm{~Hz}), 21.2 \mathrm{ppm}$.

${ }^{19} \mathrm{~F}$ NMR $\left(471 \mathrm{MHz}, \mathrm{CDCl}_{3}, 298 \mathrm{~K}, \delta\right):-100.3(\mathrm{td}, J=8.2,4.8 \mathrm{~Hz}) \mathrm{ppm}$.

HRMS-ESI (m/z) calculated for $\mathrm{C}_{24} \mathrm{H}_{16} \mathrm{O}_{7} \mathrm{~F}^{+}[\mathrm{M}+\mathrm{H}]^{+}$, 435.0875; found, 435.0873; deviation: 0.41 ppm.

2-(4-Fluorophenyl)pyrimidine (19)

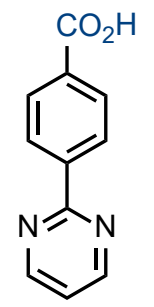

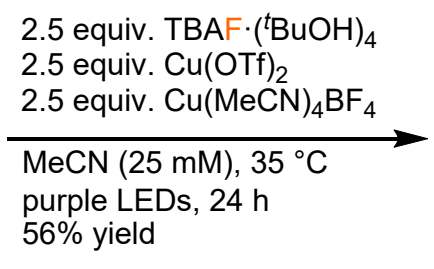

2.5 equiv. TBAF·( $\left.{ }^{(} \mathrm{BuOH}\right)_{4}$ 2.5 equiv. $\mathrm{Cu}(\mathrm{OTf})_{2}$ $\operatorname{MeCN}(25 \mathrm{mM}), 35^{\circ} \mathrm{C}$ purple LEDs, $24 \mathrm{~h}$ $56 \%$ yield

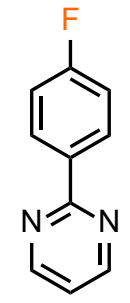

19

In a nitrogen-filled glovebox, a $16 \mathrm{~mL}$ borosilicate vial equipped with a magnetic stir bar was charged with 4(pyrimidin-2-yl)benzoic acid (40.0 mg, 0.200 mmol, 1.00 equiv.), Cu(OTf)2 (181 mg, 0.500 mmol, 2.50 equiv.), $\mathrm{Cu}(\mathrm{MeCN})_{4} \mathrm{BF}_{4}$ (157 mg, $0.500 \mathrm{mmol}, 2.50$ equiv.), and TBAF.('BuOH) 4 (279 mg, $0.500 \mathrm{mmol}, 2.50$ equiv.). $\operatorname{MeCN}(8.0 \mathrm{~mL}, \mathrm{c}=25 \mathrm{mM})$ was then added into the vial. The vial was sealed with a Teflon cap, taken out of the glovebox and placed $5 \mathrm{~cm}$ away from two purple LEDs (Kessil PR160-390 nm LEDs). The reaction mixture was stirred without irradiation for $30 \mathrm{~min}$ at ambient temperature and then irradiated for $24 \mathrm{~h}$ while maintaining the temperature at approximately $35^{\circ} \mathrm{C}$ through cooling with a fan. After irradiation, the reaction mixture was transferred to a $25 \mathrm{~mL}$ round-bottom flask and evaporated to dryness. The desidue was dissolved in DCM (20 $\mathrm{mL}$ ), transferred into a separatory funnel containing $5 \mathrm{~mL}$ saturated aqueous $\mathrm{NH}_{4} \mathrm{Cl}$ and $5 \mathrm{~mL} \mathrm{H}_{2} \mathrm{O}$, and the layers were separated. The organic layer was collected, and the aqueous layer was further extracted with DCM $\left(3 \times\right.$ ca. $20 \mathrm{~mL}$ ). The combined organic layer was dried over $\mathrm{Na}_{2} \mathrm{SO}_{4}$, filtered, and the solvent was removed under reduced pressure. The residue was purified by chromatography on silica gel (DCM) to yield a mixture. The mixture was further purified by preparative TLC (DCM/hexanes $=1 / 2, \mathrm{v} / \mathrm{v})$ to afford 2-(4fluorophenyl)pyrimidine (19) (19.6 mg, $113 \mu \mathrm{mol}, 56 \%)$ as a colorless solid.

$\mathbf{R f}=0.36(\mathrm{DCM})$.

\section{NMR Spectroscopy:}

${ }^{1} \mathrm{H}$ NMR $\left(500 \mathrm{MHz}, \mathrm{CDCl}_{3}, 298 \mathrm{~K}, \delta\right): 8.78(\mathrm{dd}, J=4.9,1.2 \mathrm{~Hz}, 2 \mathrm{H}), 8.49-8.41(\mathrm{~m}, 2 \mathrm{H}), 7.21-7.12(\mathrm{~m}, 3 \mathrm{H})$ ppm.

${ }^{13} \mathrm{C}$ NMR (126 MHz, CDCl $\left.3,298 \mathrm{~K}, \delta\right): 164.9$ (d, $\left.J=250.5 \mathrm{~Hz}\right), 163.9,157.4,133.8$ (d, $\left.J=3.0 \mathrm{~Hz}\right), 130.4$ (d, $J=8.8 \mathrm{~Hz}), 119.1,115.7(\mathrm{~d}, J=21.6 \mathrm{~Hz}) \mathrm{ppm}$.

$\left.{ }^{19} \mathrm{~F} \mathrm{NMR} \mathrm{(471} \mathrm{MHz,} \mathrm{CDCl}_{3}, 298 \mathrm{~K}, \delta\right):-110.3(\mathrm{~m}) \mathrm{ppm}$.

HRMS-Cl (Isobutane) (m/z) calculated for $\mathrm{C}_{10} \mathrm{H}_{8} \mathrm{~N}_{2} \mathrm{~F}^{+}[\mathrm{M}+\mathrm{H}]^{+}, 175.0666$; found, 175.0664; deviation: $0.92 \mathrm{ppm}$. 
4-Fluorobenzamide (20)<smiles>NC(=O)c1ccc(C(=O)O)cc1</smiles>

$$
\begin{aligned}
& 2.5 \text { equiv. TBAF·(tBuOH })_{4} \\
& 2.5 \text { equiv. } \mathrm{Cu}(\mathrm{OTf})_{2} \\
& 2.5 \text { equiv. } \mathrm{Cu}(\mathrm{MeCN})_{4} \mathrm{BF}_{4} \\
& \hline \mathrm{MeCN}(25 \mathrm{mM}), 35^{\circ} \mathrm{C} \\
& \text { purple LEDs, } 24 \mathrm{~h} \\
& 65 \% \text { yield }
\end{aligned}
$$

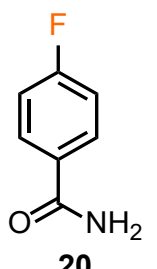

20

In a nitrogen-filled glovebox, a $16 \mathrm{~mL}$ borosilicate vial equipped with a magnetic stir bar was charged with 4carbamoylbenzoic acid (33.0 mg, $0.200 \mathrm{mmol}, 1.00$ equiv.), Cu(OTf)2 (181 mg, $0.500 \mathrm{mmol}, 2.50$ equiv.), $\mathrm{Cu}(\mathrm{MeCN})_{4} \mathrm{BF}_{4}$ (157 mg, $0.500 \mathrm{mmol}, 2.50$ equiv.), and TBAF.( $\left.{ }^{\mathrm{BuOH}}\right)_{4}(279 \mathrm{mg}, 0.500 \mathrm{mmol}, 2.50$ equiv.). $\operatorname{MeCN}(8.0 \mathrm{~mL}, \mathrm{c}=25 \mathrm{mM})$ was then added into the vial. The vial was sealed with a Teflon cap, taken out of the glovebox and placed $5 \mathrm{~cm}$ away from two purple LEDs (Kessil PR160-390 nm LEDs). The reaction mixture was stirred without irradiation for $30 \mathrm{~min}$ at ambient temperature and then irradiated for $24 \mathrm{~h}$ while maintaining the temperature at approximately $35^{\circ} \mathrm{C}$ through cooling with a fan. After irradiation, the reaction mixture was transferred to a $25 \mathrm{~mL}$ round-bottom flask and evaporated to dryness. The residue redissolved in EA (20 mL) was transferred into a separatory funnel containing $5 \mathrm{~mL}$ saturated aqueous $\mathrm{NH}_{4} \mathrm{Cl}$ and $5 \mathrm{~mL} \mathrm{H}_{2} \mathrm{O}$, and the layers were separated. The organic layer was collected, and the aqueous layer was further extracted with EA $\left(3 \times\right.$ ca. $20 \mathrm{~mL}$ ). The combined organic layer was dried over $\mathrm{Na}_{2} \mathrm{SO}_{4}$, filtered, and the solvent was removed under reduced pressure. The residue was purified by chromatography on silica gel $(E A /$ hexanes $=1 / 1, v / v)$ to yield a mixture. The mixture was further purified by preparative HPLC (8.2 min, YMC-Actus Triart C18 (150 × $\left.30.0 \mathrm{~mm}: 5 \mu \mathrm{m}+50 \times 30.0 \mathrm{~mm}: 5 \mu \mathrm{m}), \mathrm{MeCN} / \mathrm{H}_{2} \mathrm{O}=20 / 80, \mathrm{v} / \mathrm{v}, 42.5 \mathrm{~mL} / \mathrm{min}, 308 \mathrm{~K}, 254 \mathrm{~nm}\right)$. The fraction was evaporated under vacuum to remove most of the $\mathrm{MeCN}$, and the remaining mixture was extracted with EA $\left(3 \times\right.$ ca. $50 \mathrm{~mL}$ ). The combined organic layer was dried over $\mathrm{Na}_{2} \mathrm{SO}_{4}$, filtered, and the solvent was removed under reduced pressure to afford 4-fluorobenzamide (20) (18.2 mg, $131 \mu \mathrm{mol}, 65 \%)$ as a white solid.

$\boldsymbol{R} \boldsymbol{f}=0.21(\mathrm{EA} / \mathrm{hexanes}=1 / 1, \mathrm{v} / \mathrm{v})$.

\section{NMR Spectroscopy:}

${ }^{1} \mathrm{H}$ NMR $\left(500 \mathrm{MHz}, \mathrm{CD}_{3} \mathrm{CN}, 298 \mathrm{~K}, \delta\right): 7.87$ (dd, $\left.J=8.9,5.4 \mathrm{~Hz}, 2 \mathrm{H}\right), 7.18(\mathrm{t}, J=8.9 \mathrm{~Hz}, 2 \mathrm{H}), 6.78$ (brs, 1H), 6.10 (brs, 1H) ppm.

${ }^{13} \mathrm{C}$ NMR (126 MHz, CD $\left.{ }_{3} \mathrm{CN}, 298 \mathrm{~K}, \delta\right): 168.6,165.7$ (d, $\left.J=248.9 \mathrm{~Hz}\right), 131.4$ (d, J = 3.0 Hz), 131.0 (d, $J$ $=9.0 \mathrm{~Hz}), 116.2(\mathrm{~d}, J=22.1 \mathrm{~Hz}) \mathrm{ppm}$.

${ }^{19} \mathrm{~F}$ NMR $\left(471 \mathrm{MHz}, \mathrm{CD}_{3} \mathrm{CN}, 298 \mathrm{~K}, \delta\right):-110.6(\mathrm{~m}) \mathrm{ppm}$.

HRMS-El (m/z) calculated for $\mathrm{C}_{7} \mathrm{H}_{6} \mathrm{NOF}^{+}[\mathrm{M}]^{+}, 139.0428$; found, 139.0430; deviation: $-1.78 \mathrm{ppm}$. 


\section{4-Fluorobenzenesulfonamide (21)}

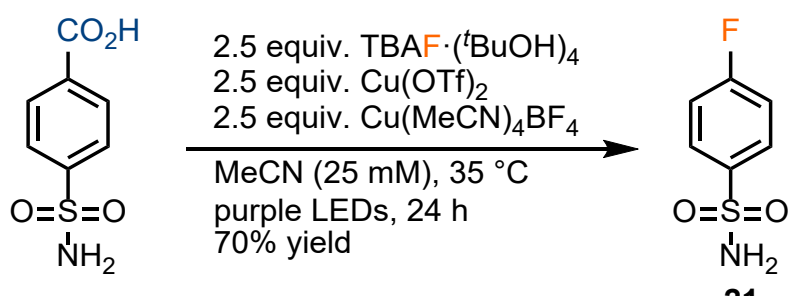

21

In a nitrogen-filled glovebox, a $16 \mathrm{~mL}$ borosilicate vial equipped with a magnetic stir bar was charged with 4sulfamoylbenzoic acid (40.2 mg, $0.200 \mathrm{mmol}, 1.00$ equiv.), $\mathrm{Cu}(\mathrm{OTf})_{2}(181 \mathrm{mg}, 0.500 \mathrm{mmol}, 2.50$ equiv.), $\mathrm{Cu}(\mathrm{MeCN})_{4} \mathrm{BF}_{4}$ (157 mg, $0.500 \mathrm{mmol}, 2.50$ equiv.), and TBAF-( $\left.{ }^{\mathrm{BuOH}}\right)_{4}(279 \mathrm{mg}, 0.500 \mathrm{mmol}, 2.50$ equiv.). $\operatorname{MeCN}(8.0 \mathrm{~mL}, \mathrm{c}=25 \mathrm{mM})$ was then added into the vial. The vial was sealed with a Teflon cap, taken out of the glovebox and placed $5 \mathrm{~cm}$ away from two purple LEDs (Kessil PR160-390 nm LEDs). The reaction mixture was stirred without irradiation for $30 \mathrm{~min}$ at ambient temperature and then irradiated for $24 \mathrm{~h}$ while maintaining the temperature at approximately $35^{\circ} \mathrm{C}$ through cooling with a fan. After irradiation, the reaction mixture was transferred to a $25 \mathrm{~mL}$ round-bottom flask and evaporated to dryness. The residue redissolved in EA (20 $\mathrm{mL})$ was transferred into a separatory funnel containing $5 \mathrm{~mL}$ saturated aqueous $\mathrm{NH}_{4} \mathrm{Cl}$ and $5 \mathrm{~mL} \mathrm{H}_{2} \mathrm{O}$, and the layers were separated. The organic layer was collected, and the aqueous layer was further extracted with EA $(3 \times$ ca. $20 \mathrm{~mL})$. The combined organic layer was dried over $\mathrm{Na}_{2} \mathrm{SO}_{4}$, filtered, and the solvent was removed under reduced pressure. The residue was purified by chromatography on silica gel (EA/hexanes $=1 / 4$ to $1 / 2$, $\mathrm{v} / \mathrm{v}$ ) to afford 4-fluorobenzenesulfonamide (21) (24.5 mg, $140 \mu \mathrm{mol}, 70 \%)$ as a colorless solid.

$\boldsymbol{R} \boldsymbol{f}=0.36(\mathrm{EA} / \mathrm{hexanes}=1 / 2, \mathrm{v} / \mathrm{v})$.

\section{NMR Spectroscopy:}

${ }^{1} \mathrm{H}$ NMR (500 MHz, $\left.\mathrm{CD}_{3} \mathrm{CN}, 298 \mathrm{~K}, \delta\right): 7.96-7.84(\mathrm{~m}, 2 \mathrm{H}), 7.32-7.24$ (m, 2H), 5.69 (brs, 2H) ppm.

${ }^{13} \mathrm{C}$ NMR (126 MHz, CD $\left.{ }_{3} \mathrm{CN}, 298 \mathrm{~K}, \delta\right): 165.7$ (d, $\left.J=251.0 \mathrm{~Hz}\right), 140.6(\mathrm{~d}, J=3.1 \mathrm{~Hz}), 129.9$ (d, $J=9.3$ $\mathrm{Hz}), 117.0$ (d, $J=22.7 \mathrm{~Hz}$ ) ppm.

${ }^{19} \mathrm{~F}$ NMR $\left(471 \mathrm{MHz}, \mathrm{CD}_{3} \mathrm{CN}, 298 \mathrm{~K}, \delta\right):-108.6(\mathrm{~m}) \mathrm{ppm}$.

HRMS-EI (m/z) calculated for $\mathrm{C}_{6} \mathrm{H}_{6} \mathrm{NO}_{2} \mathrm{SF}^{+}[\mathrm{M}]^{+}, 175.0098$; found, 175.0100; deviation: -1.37 ppm. 
Diflusinal acetate derivative 22 and oxydecarboxylation product $22 \mathrm{a}$

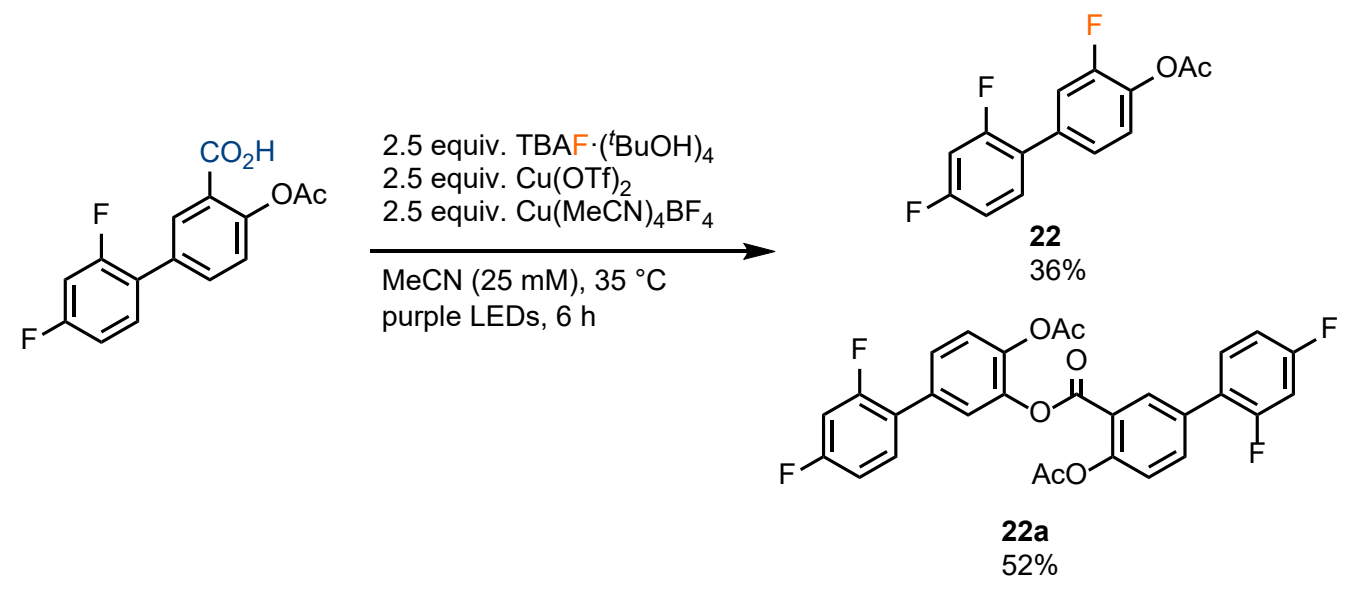

In a nitrogen-filled glovebox, a $16 \mathrm{~mL}$ borosilicate vial equipped with a magnetic stir bar was charged with diflusinal acetate (58.4 mg, $0.200 \mathrm{mmol}, 1.00$ equiv.), $\mathrm{Cu}(\mathrm{OTf})_{2}(181 \mathrm{mg}, 0.500 \mathrm{mmol}, 2.50$ equiv.), $\mathrm{Cu}(\mathrm{MeCN})_{4} \mathrm{BF}_{4}\left(157 \mathrm{mg}, 0.500 \mathrm{mmol}, 2.50 \text { equiv.), and TBAF.( }{ }^{\mathrm{B} u O H}\right)_{4}(279 \mathrm{mg}, 0.500 \mathrm{mmol}, 2.50$ equiv.). MeCN ( $8.0 \mathrm{~mL}, \mathrm{c}=25 \mathrm{mM}$ ) was then added into the vial. The vial was sealed with a Teflon cap, taken out of the glovebox and placed $5 \mathrm{~cm}$ away from two purple LEDs (Kessil PR160-390 nm LEDs). The reaction mixture was stirred without irradiation for $30 \mathrm{~min}$ at ambient temperature and then irradiated for $6 \mathrm{~h}$ while maintaining the temperature at approximately $35^{\circ} \mathrm{C}$ through cooling with a fan. After irradiation, the reaction mixture was transferred to a $25 \mathrm{~mL}$ round-bottom flask and evaporated to dryness. The desidue was dissolved in DCM (20 $\mathrm{mL}$ ), transferred into a separatory funnel containing $5 \mathrm{~mL}$ saturated aqueous $\mathrm{NH}_{4} \mathrm{Cl}$ and $5 \mathrm{~mL} \mathrm{H}_{2} \mathrm{O}$, and the layers were separated. The organic layer was collected, and the aqueous layer was further extracted with DCM ( $3 \times$ ca. $20 \mathrm{~mL}$ ). The combined organic layer was dried over $\mathrm{Na}_{2} \mathrm{SO}_{4}$, filtered, and the solvent was removed under reduced pressure. The residue was purified by chromatography on silica gel (EA/hexanes $=1 / 20$ to $1 / 8$, $\mathrm{v} / \mathrm{v})$ to afford oxydecarboxylation product $22 \mathrm{a}(28.1 \mathrm{mg}, 52 \mu \mathrm{mol}, 52 \%)$ and a mixture containing diflusinal acetate derivative 22. The mixture was further purified by preparative TLC (EA/DCM/hexanes, 3/10/90, v/v/v) to afford diflusinal acetate derivative $22(19.2 \mathrm{mg}, 72 \mu \mathrm{mol}, 36 \%)$ as a colorless solid.

Diflusinal acetate derivative 22

$\boldsymbol{R} \boldsymbol{f}=0.65(\mathrm{EA} / \mathrm{DCM} / \mathrm{hexanes}=1 / 1 / 8, \mathrm{v} / \mathrm{v} / \mathrm{v})$.

\section{NMR Spectroscopy:}

${ }^{1} \mathrm{H}$ NMR $\left(500 \mathrm{MHz}, \mathrm{CDCl}_{3}, 298 \mathrm{~K}, \delta\right): 7.38(\mathrm{td}, J=8.7,6.4 \mathrm{~Hz}, 1 \mathrm{H}), 7.33(\mathrm{~d}, J=11.1 \mathrm{~Hz}, 1 \mathrm{H}), 7.27(\mathrm{~d}, J=$ $8.1 \mathrm{~Hz}, 1 \mathrm{H}), 7.20(\mathrm{t}, J=8.1 \mathrm{~Hz}, 1 \mathrm{H}), 7.01-6.89(\mathrm{~m}, 2 \mathrm{H}), 2.37(\mathrm{~s}, 3 \mathrm{H}) \mathrm{ppm}$.

${ }^{13} \mathrm{C}$ NMR (126 MHz, CDCl $\left.3,298 \mathrm{~K}, \delta\right): 168.5,162.8$ (dd, $\left.J=250.2,11.8 \mathrm{~Hz}\right), 159.8$ (dd, $J=251.3,12.0$ Hz), 154.0 (d, $J=249.5 \mathrm{~Hz}), 137.7$ (d, $J=12.9 \mathrm{~Hz}), 134.3$ (d, $J=7.5 \mathrm{~Hz}), 131.4$ (dd, $J=9.5,4.7 \mathrm{~Hz})$, 125.1 (t, $J=3.3 \mathrm{~Hz}), 123.9$ (d, $J=1.2 \mathrm{~Hz}), 123.6(\mathrm{~d}, J=10.8 \mathrm{~Hz}), 117.4$ (dd, $J=19.8,3.3 \mathrm{~Hz}$ ), 112.0 (dd, $J=21.2,3.8 \mathrm{~Hz}), 104.7(\mathrm{t}, J=25.9 \mathrm{~Hz}), 20.7 \mathrm{ppm}$.

${ }^{19} \mathrm{~F}$ NMR $\left(471 \mathrm{MHz}, \mathrm{CDCl}_{3}, 298 \mathrm{~K}, \delta\right):-110.2(\mathrm{p}, J=7.8 \mathrm{~Hz}),-113.2(\mathrm{q}, J=9.0 \mathrm{~Hz}),-127.9$ (dd, $J=11.2$, 
$7.7 \mathrm{~Hz})$ ppm.

HRMS-Cl (Isobutane) (m/z) calculated for $\mathrm{C}_{14} \mathrm{H}_{10} \mathrm{O}_{2} \mathrm{~F}_{3}{ }^{+}[\mathrm{M}+\mathrm{H}]^{+}, 267.0627$; found, 267.0628; deviation: -0.07 ppm.

Oxydecarboxylation product 22a

$\mathbf{R} \boldsymbol{f}=0.26(\mathrm{EA} / \mathrm{DCM} / \mathrm{hexanes} /, 1 / 1 / 8, \mathrm{v} / \mathrm{v} / \mathrm{v})$.

\section{NMR Spectroscopy:}

${ }^{1} \mathrm{H}$ NMR $\left(500 \mathrm{MHz}, \mathrm{CDCl}_{3}, 298 \mathrm{~K}, \delta\right): 8.35$ (d, J = 1.2 Hz, 1H), 7.80 (dt, J = 8.4, $\left.1.9 \mathrm{~Hz}, 1 \mathrm{H}\right), 7.51-7.37$ $(\mathrm{m}, 4 \mathrm{H}), 7.32(\mathrm{~d}, J=8.2 \mathrm{~Hz}, 1 \mathrm{H}), 7.29-7.24(\mathrm{~m}, 1 \mathrm{H}), 7.03-6.89(\mathrm{~m}, 4 \mathrm{H}), 2.34(\mathrm{~s}, 3 \mathrm{H}), 2.24(\mathrm{~s}, 3 \mathrm{H}) \mathrm{ppm}$.

${ }^{13} \mathrm{C}$ NMR $\left(150 \mathrm{MHz}, \mathrm{CDCl}_{3}, 298 \mathrm{~K}, \delta\right): 169.9,168.7,162.9$ (dd, $\left.J=250.4,11.8 \mathrm{~Hz}\right), 162.7$ (dd, $J=249.7$, $11.9 \mathrm{~Hz}), 161.7,159.9$ (dd, $J=251.4,9.9 \mathrm{~Hz}), 159.8$ (dd, $J=251.2,10.0 \mathrm{~Hz}$ ), 151.0, 142.1, 142.0, 135.4 (d, $J=3.4 \mathrm{~Hz}), 133.9,133.5,132.8(\mathrm{~d}, J=3.1 \mathrm{~Hz}), 131.5$ (dt, $J=9.9,5.2 \mathrm{~Hz}), 127.6(\mathrm{~d}, J=2.9 \mathrm{~Hz}), 124.6$, $124.0(\mathrm{~d}, J=3.3 \mathrm{~Hz}), 123.9,123.7$ (dd, $J=13.2,3.6 \mathrm{~Hz}), 123.4$ (dd, $J=13.5,3.9 \mathrm{~Hz}), 122.1,111.9$ (dd, $J$ $=32.2,3.8 \mathrm{~Hz}), 112.1(\mathrm{dd}, J=32.2,3.8 \mathrm{~Hz}), 112.0(\mathrm{dd}, J=32.2,3.8 \mathrm{~Hz}), 104.8(\mathrm{t}, J=21.6 \mathrm{~Hz}), 104.7(\mathrm{t}$, $J=21.6 \mathrm{~Hz}), 21.1,20.8 \mathrm{ppm}$.

${ }^{19} \mathrm{~F}$ NMR $\left(471 \mathrm{MHz}, \mathrm{CDCl}_{3}, 298 \mathrm{~K}, \delta\right):-109.7(\mathrm{p}, J=7.9 \mathrm{~Hz}),-110.4(\mathrm{p}, J=7.8 \mathrm{~Hz}),-113.1$ (q, $J=9.0$ $\mathrm{Hz}),-113.3(\mathrm{q}, J=9.0 \mathrm{~Hz}) \mathrm{ppm}$.

HRMS-ESI (m/z) calculated for $\mathrm{C}_{29} \mathrm{H}_{18} \mathrm{O}_{6} \mathrm{~F}_{4} \mathrm{Na}^{+}[\mathrm{M}+\mathrm{Na}]^{+}$, 561.0932; found, 561.0934; deviation: -0.37 ppm.

(+)-Menthol derivative 23
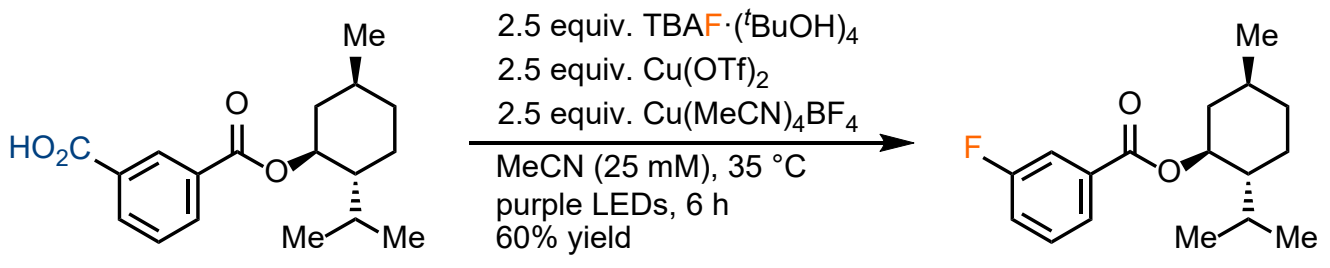

23

In a nitrogen-filled glovebox, a $16 \mathrm{~mL}$ borosilicate vial equipped with a magnetic stir bar was charged with (+)menthol derivative (S5) (60.9 mg, $0.200 \mathrm{mmol}, 1.00$ equiv.), Cu(OTf)2 (181 mg, $0.500 \mathrm{mmol}, 2.50$ equiv.), $\mathrm{Cu}(\mathrm{MeCN})_{4} \mathrm{BF}_{4}$ (157 mg, $0.500 \mathrm{mmol}, 2.50$ equiv.), and TBAF.('BuOH) 4 (279 mg, $0.500 \mathrm{mmol}, 2.50$ equiv.). $\operatorname{MeCN}(8.0 \mathrm{~mL}, \mathrm{c}=25 \mathrm{mM}$ ) was then added into the vial. The vial was sealed with a Teflon cap, taken out of the glovebox and placed $5 \mathrm{~cm}$ away from two purple LEDs (Kessil PR160-390 nm LEDs). The reaction mixture was stirred without irradiation for $30 \mathrm{~min}$ at ambient temperature and then irradiated for $6 \mathrm{~h}$ while maintaining the temperature at approximately $35^{\circ} \mathrm{C}$ through cooling with a fan. After irradiation, the reaction mixture was transferred to a $25 \mathrm{~mL}$ round-bottom flask and evaporated to dryness. The desidue was dissolved in DCM (20 $\mathrm{mL}$ ), transferred into a separatory funnel containing $5 \mathrm{~mL}$ saturated aqueous $\mathrm{NH}_{4} \mathrm{Cl}$ and $5 \mathrm{~mL} \mathrm{H}_{2} \mathrm{O}$, and the layers were separated. The organic layer was collected, and the aqueous layer was further extracted with DCM ( $3 \times$ ca. $20 \mathrm{~mL}$ ). The combined organic layer was dried over $\mathrm{Na}_{2} \mathrm{SO}_{4}$, filtered, and the solvent was removed 
under reduced pressure. The residue was purified by chromatography on silica gel (hexanes/EA $=1 / 50, v / v)$ to yield a mixture. The mixture was further purified by preparative HPLC (16.6 min, YMC-Actus Triart C18 (150 × $30.0 \mathrm{~mm}: 5 \mu \mathrm{m}+50 \times 30.0 \mathrm{~mm}: 5 \mu \mathrm{m}), \mathrm{MeCN} / \mathrm{H}_{2} \mathrm{O}=80 / 20$ to 85/15, v/v over $30 \mathrm{~min}, 42.5 \mathrm{~mL} / \mathrm{min}, 308 \mathrm{~K}, 254$ $\mathrm{nm}$ ). The fraction was evaporated under vacuum to remove most of the $\mathrm{MeCN}$, and the remaining mixture was extracted with DCM $(3 \times$ ca. $50 \mathrm{~mL})$. The combined organic layer was dried over $\mathrm{Na}_{2} \mathrm{SO}_{4}$, filtered, and the solvent was removed under reduced pressure to afford (+)-menthol derivative (23) (33.5 mg, $120 \mu \mathrm{mol}, 60 \%)$ as a colorless oil.

$\mathbf{R f}=0.50($ hexanes/EA $=20 / 1, \mathrm{v} / \mathrm{v})$.

\section{NMR Spectroscopy:}

${ }^{1} \mathrm{H}$ NMR (500 MHz, $\left.\mathrm{CDCl}_{3}, 298 \mathrm{~K}, \delta\right): 7.83(\mathrm{dd}, J=7.7,1.2 \mathrm{~Hz}, 1 \mathrm{H}), 7.71(\mathrm{dt}, J=9.5,2.2 \mathrm{~Hz}, 1 \mathrm{H}), 7.41$ (td, $J=8.0,5.5 \mathrm{~Hz}, 1 \mathrm{H}), 7.26-7.22(\mathrm{~m}, 1 \mathrm{H}), 4.93(\mathrm{td}, J=10.9,4.4 \mathrm{~Hz}, 1 \mathrm{H}), 2.12(\mathrm{dtd}, J=12.1,4.1,1.7$ $\mathrm{Hz}, 1 \mathrm{H}), 1.94(\mathrm{pd}, J=7.0,2.8 \mathrm{~Hz}, 1 \mathrm{H}), 1.76-1.71(\mathrm{~m}, 2 \mathrm{H}), 1.58-1.51(\mathrm{~m}, 2 \mathrm{H}), 1.18-1.05(\mathrm{~m}, 2 \mathrm{H}), 0.92(\mathrm{~m}$, $7 \mathrm{H}), 0.79(\mathrm{~d}, J=6.9 \mathrm{~Hz}, 3 \mathrm{H}) \mathrm{ppm}$.

${ }^{13} \mathrm{C}$ NMR (126 MHz, $\left.\mathrm{CDCl}_{3}, 298 \mathrm{~K}, \delta\right): 165.1$ (d, $\left.J=3.0 \mathrm{~Hz}\right), 162.7$ (d, $\left.J=246.8 \mathrm{~Hz}\right), 133.2$ (d, J = 7.2 Hz), 130.1 (d, $J=7.7 \mathrm{~Hz}), 125.4$ (d, $J=3.0 \mathrm{~Hz}), 119.9$ (d, $J=21.4 \mathrm{~Hz}), 116.6$ (d, $J=23.1 \mathrm{~Hz}), 75.5,47.4,41.1$, $34.4,31.6,26.7,23.8,22.2,20.9,16.6 \mathrm{ppm}$.

${ }^{19} \mathrm{~F}$ NMR $\left(471 \mathrm{MHz}, \mathrm{CDCl}_{3}, 298 \mathrm{~K}, \delta\right):-112.6(\mathrm{~m}) \mathrm{ppm}$.

HRMS-ESI (m/z) calculated for $\mathrm{C}_{17} \mathrm{H}_{23} \mathrm{O}_{2} \mathrm{FNa}^{+}[\mathrm{M}+\mathrm{Na}]^{+}$, 301.1574; found, 301.1573; deviation: 0.32 ppm.

4-Fluorophenyl benzoate (24)

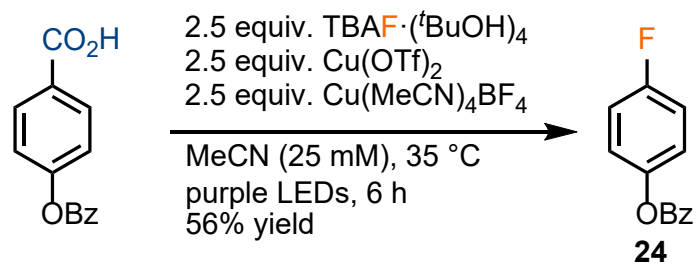

In a nitrogen-filled glovebox, a $16 \mathrm{~mL}$ borosilicate vial equipped with a magnetic stir bar was charged with 4(benzoyloxy)benzoic acid (48.4 mg, $0.200 \mathrm{mmol}, 1.00$ equiv.), Cu(OTf)2 (181 mg, $0.500 \mathrm{mmol}, 2.50$ equiv.), $\mathrm{Cu}(\mathrm{MeCN})_{4} \mathrm{BF}_{4}\left(157 \mathrm{mg}, 0.500 \mathrm{mmol}, 2.50 \text { equiv.), and TBAF·( }{ }^{\mathrm{t} B u O H}\right)_{4}(279 \mathrm{mg}, 0.500 \mathrm{mmol}, 2.50$ equiv.). $\operatorname{MeCN}(8.0 \mathrm{~mL}, \mathrm{C}=25 \mathrm{mM})$ was then added into the vial. The vial was sealed with a Teflon cap, taken out of the glovebox and placed $5 \mathrm{~cm}$ away from two purple LEDs (Kessil PR160-390 nm LEDs). The reaction mixture was stirred without irradiation for $30 \mathrm{~min}$ at ambient temperature and then irradiated for $6 \mathrm{~h}$ while maintaining the temperature at approximately $35^{\circ} \mathrm{C}$ through cooling with a fan. After irradiation, the reaction mixture was transferred to a $25 \mathrm{~mL}$ round-bottom flask and evaporated to dryness. The desidue was dissolved in DCM (20 $\mathrm{mL}$ ), transferred into a separatory funnel containing $5 \mathrm{~mL}$ saturated aqueous $\mathrm{NH}_{4} \mathrm{Cl}$ and $5 \mathrm{~mL} \mathrm{H}_{2} \mathrm{O}$, and the layers were separated. The organic layer was collected, and the aqueous layer was further extracted with DCM ( $3 \times$ ca. $20 \mathrm{~mL}$ ). The combined organic layer was dried over $\mathrm{Na}_{2} \mathrm{SO}_{4}$, filtered, and the solvent was removed 
under reduced pressure. The residue was purified by chromatography on silica gel (hexanes/EA $=50 / 1, v / v)$ to yield a mixture. The mixture was further purified by preparative HPLC (29.5 min, YMC-Actus Pro C18 (150 × $30.0 \mathrm{~mm}: 5 \mu \mathrm{m}+50 \times 30.0 \mathrm{~mm}: 5 \mu \mathrm{m}), \mathrm{MeCN} / \mathrm{H}_{2} \mathrm{O}=45 / 55$ to $50 / 50$, v/v over $40 \mathrm{~min}, 42.5 \mathrm{~mL} / \mathrm{min}, 308 \mathrm{~K}, 254$ $\mathrm{nm}$ ). The fraction was evaporated under vacuum to remove most of the $\mathrm{MeCN}$, and the remaining mixture was extracted with DCM $(3 \times$ ca. $50 \mathrm{~mL})$. The combined organic layer was dried over $\mathrm{Na}_{2} \mathrm{SO}_{4}$, filtered, and the solvent was removed under reduced pressure to afford 4-fluorophenyl benzoate (24) (24.1 mg, $111 \mu \mathrm{mol}, 56 \%)$ as a colorless solid.

$\mathbf{R} \boldsymbol{f}=0.40($ hexanes $/ E A=25 / 1, \mathrm{v} / \mathrm{v})$

\section{NMR Spectroscopy:}

${ }^{1} \mathrm{H}$ NMR $\left(500 \mathrm{MHz}, \mathrm{CDCl}_{3}, 298 \mathrm{~K}, \delta\right): 8.20(\mathrm{dd}, J=8.3,1.4 \mathrm{~Hz}, 2 \mathrm{H}), 7.65(\mathrm{t}, J=7.4 \mathrm{~Hz}, 1 \mathrm{H}), 7.52(\mathrm{t}, J=$ $7.8 \mathrm{~Hz}, 2 \mathrm{H}), 7.21-7.17(\mathrm{~m}, 2 \mathrm{H}), 7.16-7.09(\mathrm{~m}, 2 \mathrm{H}) \mathrm{ppm}$.

${ }^{13} \mathrm{C}$ NMR (126 MHz, $\left.\mathrm{CDCl}_{3}, 298 \mathrm{~K}, \delta\right): 165.3,160.4$ (d, $\left.J=244.0 \mathrm{~Hz}\right), 146.9$ (d, $\left.J=2.9 \mathrm{~Hz}\right), 133.8,130.3$, 129.4, 128.8, 123.2 (d, $J=8.5 \mathrm{~Hz}), 116.3$ (d, $J=23.7 \mathrm{~Hz}) \mathrm{ppm}$.

${ }^{19} \mathrm{~F}$ NMR $\left(471 \mathrm{MHz}, \mathrm{CDCl}_{3}, 298 \mathrm{~K}, \delta\right):-117.0(\mathrm{~m}) \mathrm{ppm}$.

HRMS-El (m/z) calculated for $\mathrm{C}_{13} \mathrm{H}_{9} \mathrm{O}_{2} \mathrm{~F}^{+}[\mathrm{M}]^{+}, 216.0581$; found, 216.0576; deviation: 2.45 ppm.

\section{2-Chloro-1-fluoro-3-methylbenzene (25)}

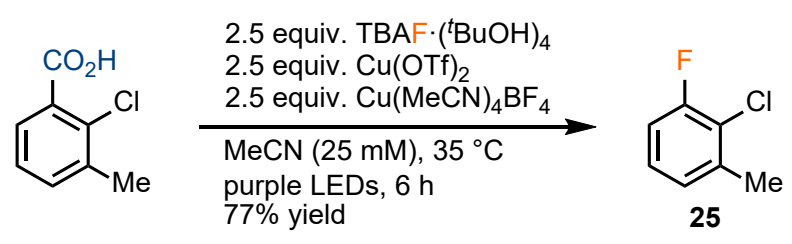

In a nitrogen-filled glovebox, a $16 \mathrm{~mL}$ borosilicate vial equipped with a magnetic stir bar was charged with 2chloro-3-methylbenzoic acid (34.1 mg, 0.200 mmol, 1.00 equiv.), Cu(OTf) 2 (181 mg, 0.500 mmol, 2.50 equiv.), $\mathrm{Cu}(\mathrm{MeCN})_{4} \mathrm{BF}_{4}$ (157 mg, $0.500 \mathrm{mmol}, 2.50$ equiv.), and TBAF.( $\left.{ }^{\mathrm{BuOH}}\right)_{4}(279 \mathrm{mg}, 0.500 \mathrm{mmol}, 2.50$ equiv.). MeCN ( $8.0 \mathrm{~mL}, \mathrm{c}=25 \mathrm{mM}$ ) was then added into the vial. The vial was sealed with a Teflon cap, taken out of the glovebox and placed $5 \mathrm{~cm}$ away from two purple LEDs (Kessil PR160-390 nm LEDs). The reaction mixture was stirred without irradiation for $30 \mathrm{~min}$ at ambient temperature and then irradiated for $6 \mathrm{~h}$ while maintaining the temperature at approximately $35^{\circ} \mathrm{C}$ through cooling with a fan. After being irradiated for $6 \mathrm{~h}$, the reaction mixture was cooled to room temperature. 2-fluorotoluene (22.0 mg, $22.0 \mu \mathrm{L}, 0.200 \mathrm{mmol}, 1.00$ equiv.) was added as an internal standard. The reaction mixture was diluted with $\mathrm{CD}_{3} \mathrm{CN}$, and the yield of 2-chloro-1-fluoro3-methylbenzene (25) was determined by ${ }^{19} \mathrm{~F}$ NMR integration relative to the internal standard $(78 \%$ yield, standard: $\delta-119.4(\mathrm{~m})$ ppm, and 25: $\delta-109.4(\mathrm{~m})$ ppm, Figure S16). The identity of the product was further confirmed by GCMS analysis (Figure $\mathbf{S 1 7}$ ).

The yield of 25 reported in the manuscript (77\%) represents an average of two runs [78\% (above) and $75 \%$ ] 


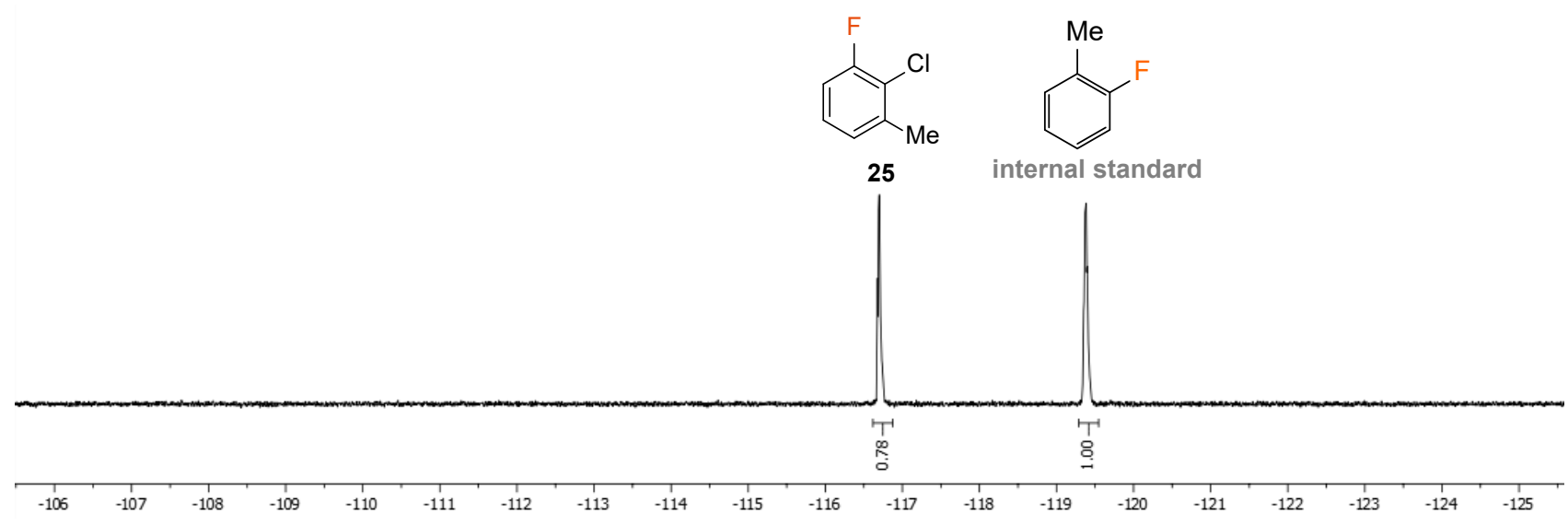

Figure S16. ${ }^{19} \mathrm{~F}$ NMR of resulting mixtures for product 25.

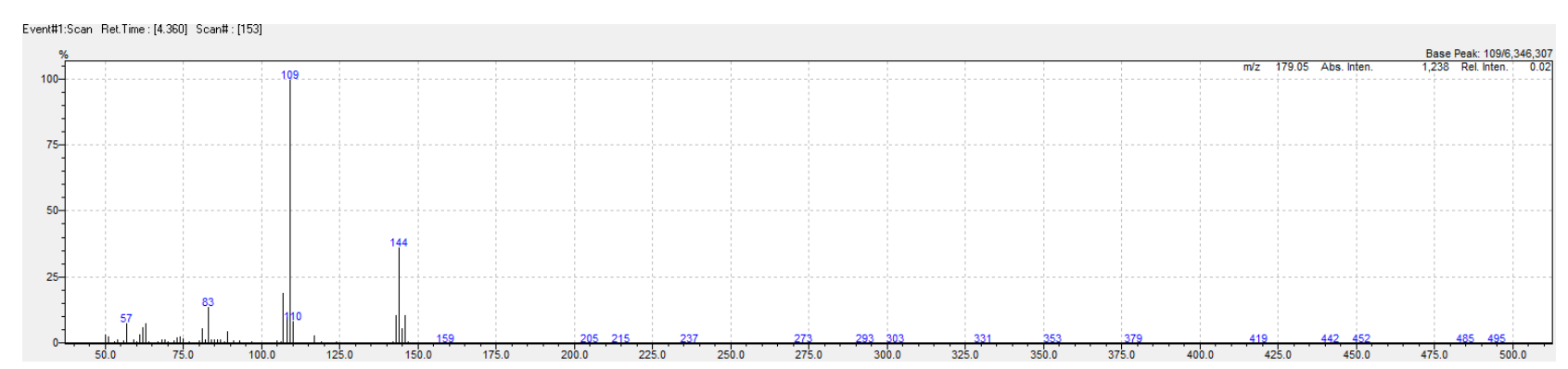

Figure S17. Mass spectrum of product 25 peak from GCMS.

2-Fluoro-4-methoxyquinoline (26)

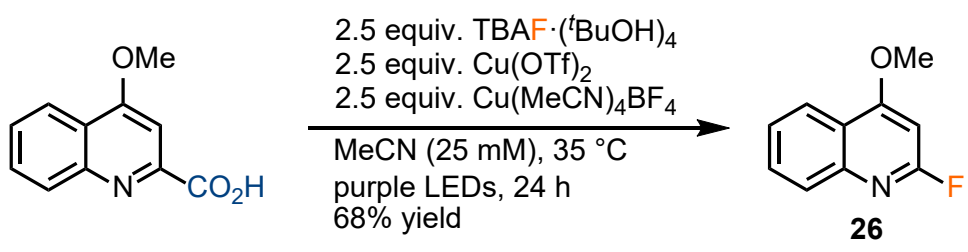

In a nitrogen-filled glovebox, a $16 \mathrm{~mL}$ borosilicate vial equipped with a magnetic stir bar was charged with $O$ metylkynurenic acid (40.6 mg, $0.200 \mathrm{mmol}, 1.00$ equiv.), Cu(OTf) 2 (181 mg, $0.500 \mathrm{mmol}, 2.50$ equiv.), $\mathrm{Cu}(\mathrm{MeCN})_{4} \mathrm{BF}_{4}\left(157 \mathrm{mg}, 0.500 \mathrm{mmol}, 2.50 \text { equiv.), and TBAF.( }{ }^{\mathrm{B}} \mathrm{BuOH}\right)_{4}(279 \mathrm{mg}, 0.500 \mathrm{mmol}, 2.50$ equiv.). $\operatorname{MeCN}(8.0 \mathrm{~mL}, \mathrm{c}=25 \mathrm{mM})$ was then added into the vial. The vial was sealed with a Teflon cap, taken out of the glovebox and placed $5 \mathrm{~cm}$ away from two purple LEDs (Kessil PR160-390 nm LEDs). The reaction mixture was stirred without irradiation for $30 \mathrm{~min}$ at ambient temperature and then irradiated for $24 \mathrm{~h}$ while maintaining the temperature at approximately $35^{\circ} \mathrm{C}$ through cooling with a fan. After irradiation, the reaction mixture was transferred to a $25 \mathrm{~mL}$ round-bottom flask and evaporated to dryness. The desidue was dissolved in DCM (20 $\mathrm{mL}$ ), transferred into a separatory funnel containing $5 \mathrm{~mL}$ saturated aqueous $\mathrm{NH}_{4} \mathrm{Cl}$ and $5 \mathrm{~mL} \mathrm{H}_{2} \mathrm{O}$, and the layers were separated. The organic layer was collected, and the aqueous layer was further extracted with DCM $\left(3 \times\right.$ ca. $20 \mathrm{~mL}$ ). The combined organic layer was dried over $\mathrm{Na}_{2} \mathrm{SO}_{4}$, filtered, and the solvent was removed under reduced pressure. The residue was purified by chromatography on silica gel (EA/hexanes/DCM = 
1/20/20, v/v/v) to afford 2-fluoro-4-methoxyquinoline (26) $(24.1 \mathrm{mg}, 136 \mu \mathrm{mol}, 68 \%)$ as a colorless solid.

$\mathbf{R} \boldsymbol{f}=0.50(\mathrm{EA} / \mathrm{hexanes} / \mathrm{DCM}=1 / 10 / 10, \mathrm{v} / \mathrm{v} / \mathrm{v})$.

\section{NMR Spectroscopy:}

${ }^{1} \mathrm{H}$ NMR $\left(500 \mathrm{MHz}, \mathrm{CD}_{3} \mathrm{CN}, 298 \mathrm{~K}, \delta\right): 8.11$ (dd, $\left.J=8.3,1.6 \mathrm{~Hz}, 1 \mathrm{H}\right), 7.79$ (d, $J=8.4 \mathrm{~Hz}, 1 \mathrm{H}$ ), 7.72 (ddd, $J=8.5,6.8,1.5 \mathrm{~Hz}, 1 \mathrm{H}), 7.50$ (ddd, $J=8.2,6.8,1.2 \mathrm{~Hz}, 1 \mathrm{H}), 6.56(\mathrm{~s}, 1 \mathrm{H}), 4.06(\mathrm{~s}, 3 \mathrm{H}) \mathrm{ppm}$.

${ }^{13} \mathrm{C}$ NMR (126 MHz, CD $\left.{ }_{3} \mathrm{CN}, 298 \mathrm{~K}, \delta\right): 167.5$ (d, $\left.J=13.7 \mathrm{~Hz}\right), 163.6(\mathrm{~d}, J=233.7 \mathrm{~Hz}), 146.7$ (d, $J=21.5$ $\mathrm{Hz}), 131.9,128.5,126.3$ (d, $J=2.5 \mathrm{~Hz}), 122.9,121.3,89.9$ (d, $J=48.3 \mathrm{~Hz}), 57.5 \mathrm{ppm}$.

${ }^{19} \mathrm{~F}$ NMR (471 MHz, CD 3 CN, $\left.298 \mathrm{~K}, \delta\right):-61.1$ (s) ppm.

HRMS-El (m/z) calculated for $\mathrm{C}_{10} \mathrm{H}_{8} \mathrm{NOF}^{+}[\mathrm{M}]^{+}, 177.0584$; found, 177.0585; deviation: -0.27 ppm.

\section{N-Succinimidyl 4-fluorobenzoate (27)}
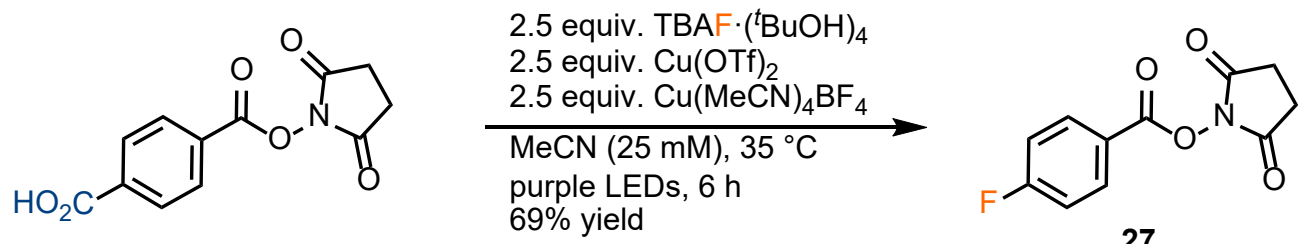

27

In a nitrogen-filled glovebox, a $16 \mathrm{~mL}$ borosilicate vial equipped with a magnetic stir bar was charged with $N$ succinimidyl 4-carboxybenzoate (S7) (52.6 mg, $0.200 \mathrm{mmol}, 1.00$ equiv.), Cu(OTf)2 (181 mg, $0.500 \mathrm{mmol}, 2.50$ equiv.), $\mathrm{Cu}(\mathrm{MeCN})_{4} \mathrm{BF}_{4}\left(157 \mathrm{mg}, 0.500 \mathrm{mmol}, 2.50 \text { equiv.), and TBAF·( }{ }^{(B u O H}\right)_{4}(279 \mathrm{mg}, 0.500 \mathrm{mmol}, 2.50$ equiv.). MeCN ( $8.0 \mathrm{~mL}, \mathrm{c}=25 \mathrm{mM}$ ) was then added into the vial. The vial was sealed with a Teflon cap, taken out of the glovebox and placed $5 \mathrm{~cm}$ away from two purple LEDs (Kessil PR160-390 nm LEDs). The reaction mixture was stirred without irradiation for $30 \mathrm{~min}$ at ambient temperature and then irradiated for $6 \mathrm{~h}$ while maintaining the temperature at approximately $35^{\circ} \mathrm{C}$ through cooling with a fan. After irradiation, the reaction mixture was transferred to a $25 \mathrm{~mL}$ round-bottom flask and evaporated to dryness. The desidue was dissolved in $\mathrm{DCM}(20 \mathrm{~mL})$, transferred into a separatory funnel containing $5 \mathrm{~mL}$ saturated aqueous $\mathrm{NH}_{4} \mathrm{Cl}$ and $5 \mathrm{~mL} \mathrm{H}_{2} \mathrm{O}$, and the layers were separated. The organic layer was collected, and the aqueous layer was further extracted with DCM ( $3 \times$ ca. $20 \mathrm{~mL}$ ). The combined organic layer was dried over $\mathrm{Na}_{2} \mathrm{SO}_{4}$, filtered, and the solvent was removed under reduced pressure. The residue was purified by chromatography on silica gel (DCM/EA = 20/1, $\mathrm{v} / \mathrm{v}$ ) to yield a mixture. The mixture was further purified by preparative HPLC (18.8 min, YMC-Actus Pro C18 $\left.(150 \times 30.0 \mathrm{~mm}: 5 \mu \mathrm{m}+50 \times 30.0 \mathrm{~mm}: 5 \mu \mathrm{m}), \mathrm{MeCN} / \mathrm{H}_{2} \mathrm{O}=30 / 70, \mathrm{v} / \mathrm{v}, 42.5 \mathrm{~mL} / \mathrm{min}, 308 \mathrm{~K}, 254 \mathrm{~nm}\right)$. The fraction was evaporated under vacuum to remove most of the $\mathrm{MeCN}$, and the remaining mixture was extracted with DCM ( $3 \times$ ca. $50 \mathrm{~mL}$ ). The combined organic layer was dried over $\mathrm{Na}_{2} \mathrm{SO}_{4}$, filtered, and the solvent was removed under reduced pressure to afford $\mathrm{N}$-succinimidyl 4-fluorobenzoate (27) (32.5 mg, $137 \mu \mathrm{mol}, 69 \%)$ as a colorless solid.

$\mathbf{R} f=0.20(\mathrm{DCM})$. 
${ }^{1} \mathrm{H}$ NMR $\left(500 \mathrm{MHz}, \mathrm{CDCl}_{3}, 298 \mathrm{~K}, \delta\right): 8.33-7.97(\mathrm{~m}, 2 \mathrm{H}), 7.18(\mathrm{t}, \mathrm{J}=8.6 \mathrm{~Hz}, 2 \mathrm{H}), 2.89(\mathrm{~s}, 4 \mathrm{H}) \mathrm{ppm}$.

${ }^{13} \mathrm{C}$ NMR $\left(126 \mathrm{MHz}, \mathrm{CDCl}_{3}, 298 \mathrm{~K}, \delta\right): 169.3,167.0$ (d, $\left.J=258.0 \mathrm{~Hz}\right), 161.0,133.5(\mathrm{~d}, J=10.0 \mathrm{~Hz}), 121.5$ (d, $J=3.0 \mathrm{~Hz}), 116.4$ (d, J = 22.2 Hz), $25.8 \mathrm{ppm}$.

${ }^{19} \mathrm{~F}$ NMR $\left(471 \mathrm{MHz}, \mathrm{CDCl}_{3}, 298 \mathrm{~K}, \delta\right):-101.3(\mathrm{~m}) \mathrm{ppm}$.

HRMS-ESI (m/z) calculated for $\mathrm{C}_{11} \mathrm{H}_{8} \mathrm{NO}_{4} \mathrm{FNa}^{+}[\mathrm{M}+\mathrm{Na}]^{+}$, 260.0330; found, 260.0330; deviation: -0.13 ppm.

Fenofibrate analogue 28
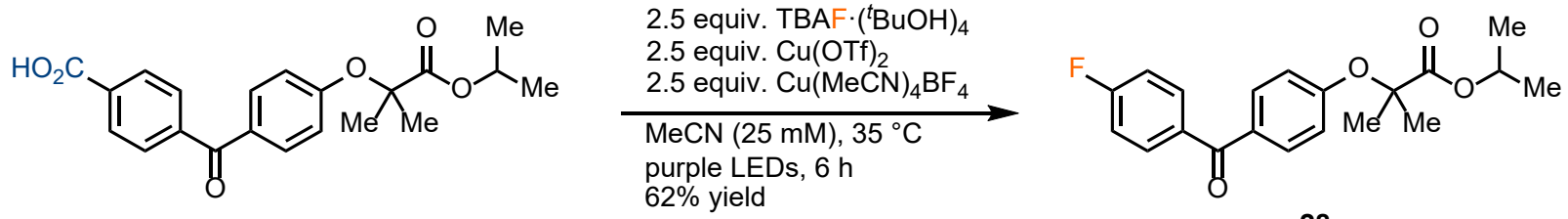

28

In a nitrogen-filled glovebox, a $16 \mathrm{~mL}$ borosilicate vial equipped with a magnetic stir bar was charged with fenofibrate derivative $\mathbf{S} 8$ (74.1 $\mathrm{mg}, 0.200 \mathrm{mmol}, 1.00$ equiv.), $\mathrm{Cu}(\mathrm{OTf})_{2}$ (181 mg, $0.500 \mathrm{mmol}, 2.50$ equiv.), $\mathrm{Cu}(\mathrm{MeCN})_{4} \mathrm{BF}_{4}$ (157 mg, $0.500 \mathrm{mmol}, 2.50$ equiv.), and TBAF·( $\left.{ }^{\mathrm{BuOH}}\right)_{4}(279 \mathrm{mg}, 0.500 \mathrm{mmol}, 2.50$ equiv.). MeCN (8.0 mL, c = $25 \mathrm{mM}$ ) was then added into the vial. The vial was sealed with a Teflon cap, taken out of the glovebox and placed $5 \mathrm{~cm}$ away from two purple LEDs (Kessil PR160-390 nm LEDs). The reaction mixture was stirred without irradiation for $30 \mathrm{~min}$ at ambient temperature and then irradiated for $6 \mathrm{~h}$ while maintaining the temperature at approximately $35^{\circ} \mathrm{C}$ through cooling with a fan. After irradiation, the reaction mixture was transferred to a $25 \mathrm{~mL}$ round-bottom flask and evaporated to dryness. The desidue was dissolved in DCM (20 $\mathrm{mL}$ ), transferred into a separatory funnel containing $5 \mathrm{~mL}$ saturated aqueous $\mathrm{NH}_{4} \mathrm{Cl}$ and $5 \mathrm{~mL} \mathrm{H}_{2} \mathrm{O}$, and the layers were separated. The organic layer was collected, and the aqueous layer was further extracted with DCM $(3 \times$ ca. $20 \mathrm{~mL})$. The combined organic layer was dried over $\mathrm{Na}_{2} \mathrm{SO}_{4}$, filtered, and the solvent was removed under reduced pressure. The residue was purified by chromatography on silica gel $(E A / h e x a n e s=1 / 8, v / v)$ to yield a mixture. The mixture was further purified by preparative HPLC (39.2 min, YMC-Actus Pro C18 (150 × $30.0 \mathrm{~mm}: 5 \mu \mathrm{m}+50 \times 30.0 \mathrm{~mm}: 5 \mu \mathrm{m}), \mathrm{MeCN} / \mathrm{H}_{2} \mathrm{O}=40 / 60$ to 65/35, v/v over $40 \mathrm{~min}, 42.5 \mathrm{~mL} / \mathrm{min}, 308 \mathrm{~K}, 254$ $\mathrm{nm}$ ). The fraction was evaporated under vacuum to remove most of the $\mathrm{MeCN}$, and the remaining mixture was extracted with DCM $\left(3 \times\right.$ ca. $50 \mathrm{~mL}$ ). The combined organic layer was dried over $\mathrm{Na}_{2} \mathrm{SO}_{4}$, filtered, and the solvent was removed under reduced pressure to afford fenofibrate analogue 28 ( $42.6 \mathrm{mg}, 124 \mu \mathrm{mol}, 62 \%$ ) as a colorless oil.

$\mathbf{R} \boldsymbol{f}=0.72(\mathrm{EA} / \mathrm{hexanes}=1 / 4, \mathrm{v} / \mathrm{v})$.

\section{NMR Spectroscopy:}

${ }^{1} \mathrm{H}$ NMR $\left(500 \mathrm{MHz}, \mathrm{CDCl}_{3}, 298 \mathrm{~K}, \delta\right): 7.78(\mathrm{dd}, J=8.8,5.4 \mathrm{~Hz}, 2 \mathrm{H}), 7.76-7.69(\mathrm{~m}, 2 \mathrm{H}), 7.14$ (t, J = 8.7 Hz, 2H), 6.90-6.83 (m, 2H), 5.08 (hept, $J=6.3 \mathrm{~Hz}, 1 \mathrm{H}), 1.66(\mathrm{~s}, 6 \mathrm{H}), 1.20(\mathrm{~s}, 3 \mathrm{H}), 1.19(\mathrm{~s}, 3 \mathrm{H}) \mathrm{ppm}$.

${ }^{13} \mathrm{C}$ NMR (126 MHz, $\left.\mathrm{CDCl}_{3}, 298 \mathrm{~K}, \delta\right): 194.2,173.2,165.2$ (d, J = 253.3 Hz), 159.7, 134.4 (d, J = $\left.3.1 \mathrm{~Hz}\right)$, $132.4(\mathrm{~d}, J=9.0 \mathrm{~Hz}), 132.0,130.6,117.4,115.5$ (d, $J=21.6 \mathrm{~Hz}), 79.5,69.4,25.5,21.7$ ppm. 
${ }^{19} \mathrm{~F}$ NMR $\left(471 \mathrm{MHz}, \mathrm{CDCl}_{3}, 298 \mathrm{~K}, \delta\right):-106.8(\mathrm{~m}) \mathrm{ppm}$.

HRMS-ESI (m/z) calculated for $\mathrm{C}_{20} \mathrm{H}_{22} \mathrm{O}_{4} \mathrm{~F}^{+}[\mathrm{M}+\mathrm{H}]^{+}, 345.1497$; found, 345.1496; deviation: $0.21 \mathrm{ppm}$.

\section{Other tested substrates}<smiles>Cc1cccc(F)c1</smiles>

$57 \%$<smiles>Fc1ccccc1Cl</smiles>

$82 \%$<smiles>O=[N+]([O-])c1ccccc1F</smiles>

$54 \%$<smiles>COc1ccc(F)cc1</smiles>

$40 \%$<smiles>Oc1ccc(F)cc1</smiles>

$0 \%$<smiles>Fc1ccccn1</smiles>

$0 \%$<smiles>Fc1cncc(Br)c1</smiles>

$0 \%$<smiles>CCCN(CCC)C(=O)c1ccc(F)cc1</smiles>

$0 \%$<smiles>Fc1ccc2cccc(Br)c2n1</smiles>

$0 \%$<smiles>Fc1cc2ccccc2s1</smiles>

$0 \%$<smiles>Fc1ccc2ccn(S)c2c1</smiles>

$0 \%$<smiles>Fc1cccc(-c2ccccc2C(F)(F)F)n1</smiles>

$38 \%$<smiles>O=C(c1ccc(F)cc1)N1CCOCC1</smiles>

$48 \%$<smiles>CC(=O)Oc1cccc2c1C(=O)c1c(OC(C)=O)cc(F)cc1C2=O</smiles>

$0 \%$<smiles>CN1CCN(c2ccc(F)cc2)CC1</smiles>

$0 \%$

Reaction performed outside of a glovebox by using Schlenk techniques

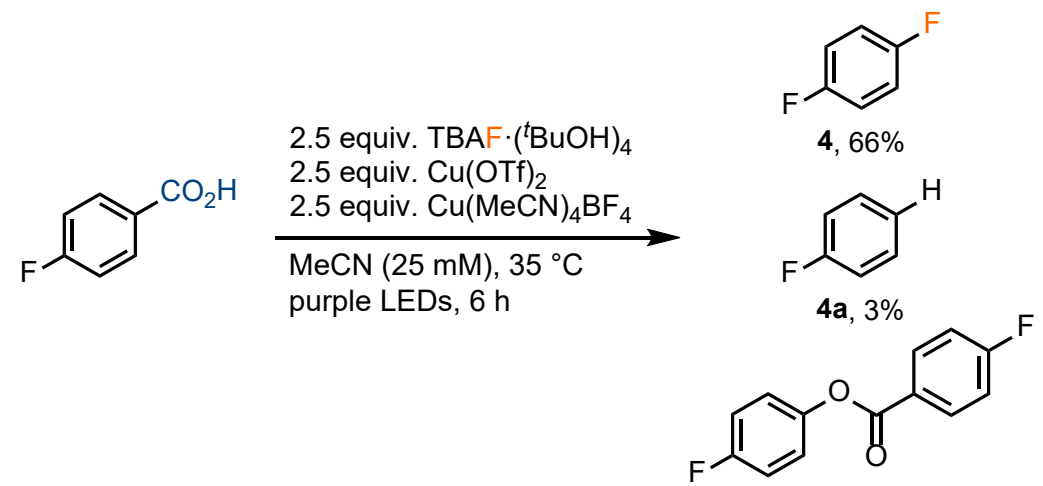

4b, $28 \%$

Under $\mathrm{N}_{2}$ atmosphere, an oven-dried $20 \mathrm{~mL}$ Schlenk tube equipped with a rubber stopper and a magnetic stir bar was charged with 4-fluorobenzoic acid (28.0 mg, $0.200 \mathrm{mmol}, 1.00$ equiv.), Cu(OTf)2 (181 mg, $0.500 \mathrm{mmol}$, 2.50 equiv.), and $\mathrm{Cu}(\mathrm{MeCN})_{4} \mathrm{BF}_{4}$ (157 mg, $0.500 \mathrm{mmol}, 2.50$ equiv.). TBAF·( $\left.{ }^{\mathrm{B} u O H}\right)_{4}(279 \mathrm{mg}, 0.500 \mathrm{mmol}$, 2.50 equiv.) was weighed and transferred to the Schlenk tube quickly, and the Schlenk tube was evacuated under low pressure (ca. $3 \times 10^{-1} \mathrm{mbar}$ ) with oil pump for $10 \mathrm{~min}$. The tube was backfilled with $\mathrm{N}_{2}$, and anhydrous $\operatorname{MeCN}(8.0 \mathrm{~mL}, \mathrm{c}=25 \mathrm{mM})$ was then added via a syringe. The tube was sealed and placed $5 \mathrm{~cm}$ away from two purple LEDs (Kessil PR160-390 nm LEDs). The reaction mixture was stirred without irradiation for 30 min at ambient temperature and then irradiated for $6 \mathrm{~h}$ while maintaining the temperature at approximately $35^{\circ} \mathrm{C}$ through cooling with a fan. After being irradiated for $6 \mathrm{~h}$, the reaction mixture was cooled to room temperature. 
2-fluorotoluene (22.0 mg, $22.0 \mu \mathrm{L}, 0.200 \mathrm{mmol}, 1.00$ equiv.) was added as an internal standard. The reaction mixture was diluted with $\mathrm{CD}_{3} \mathrm{CN}$, and the ${ }^{19} \mathrm{~F}$ NMR spectrum was measured. The yields of 1,4-difluorobenzene $(4,66 \%$ yield, $\delta-121.1(\mathrm{~m}) \mathrm{ppm})$, fluorobenzene $(4 \mathrm{a}, 3 \%$ yield, $\delta-114.9(\mathrm{~m}) \mathrm{ppm})$ and 4-fluorophenyl 4fluorobenzoate (4b, $28 \%$ yield, $\delta-118.6(\mathrm{~m}),-106.5(\mathrm{~m}) \mathrm{ppm}$ ) were determined by ${ }^{19} \mathrm{~F}$ NMR integration relative to the internal standard $(\delta-119.4(\mathrm{~m}) \mathrm{ppm})$, respectively.

\section{Preparation of starting materials}

D-Glucose derivative S2<smiles>CC(=O)OC[C@H]1O[C@H](Br)[C@@H](OC(C)=O)[C@H](OC(C)=O)[C@H]1OC(C)=O</smiles>

1.0 equiv.<smiles>O=Cc1cccc(O)c1</smiles>

1.0 equiv.

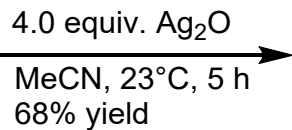

$68 \%$ yield<smiles>CC(=O)OC[C@H]1O[C@H](Oc2cccc(C=O)c2)[C@H](OC(C)=O)[C@@H](OC(C)=O)[C@@H]1O</smiles>

S2

Under $\mathrm{N}_{2}$, D-(+)-alpha-acetobromglucose (822 mg, $2.00 \mathrm{mmol}, 1.00$ equiv.), silver (I) oxide (1.86 g, $8.00 \mathrm{mmol}$, 4.00 equiv.), 3-hydroxybenzaldehyde (244 mg, $2.00 \mathrm{mmol}, 1.00$ equiv.) and $\mathrm{MeCN}(20 \mathrm{~mL})$ was added in sequence to a $100 \mathrm{~mL}$ oven-dried round-bottom flask wrapped in aluminium foil. After stirring at room temperature for $5 \mathrm{~h}$, the reaction mixture was evaporated to dryness under reduced pressure. The residue redissolved in EA was then filtered through Celite, and the Celite was washed with EA (ca. $40 \mathrm{~mL}$ ). The filtrate was evaporated under reduced pressure, and the residue was purified by chromatography on silica gel $(\mathrm{EA} /$ hexanes $=1 / 4$ to $1 / 1, \mathrm{v} / \mathrm{v})$ to afford the D-glucose derivative $\mathbf{S 2}(615 \mathrm{mg}, 1.36 \mathrm{mmol}, 68 \%)$ as a colorless solid.

$\mathbf{R f}=0.56(E A / D C M=1 / 4, v / v)$.

\section{NMR Spectroscopy:}

${ }^{1} \mathrm{H}$ NMR $\left(500 \mathrm{MHz}, \mathrm{CDCl}_{3}, 298 \mathrm{~K}, \delta\right): 9.98(\mathrm{~s}, 1 \mathrm{H}), 7.58$ (dt, J = 7.5, $\left.1.3 \mathrm{~Hz}, 1 \mathrm{H}\right), 7.54-7.42(\mathrm{~m}, 2 \mathrm{H}), 7.29$ $7.22(\mathrm{~m}, 1 \mathrm{H}), 5.36-5.26(\mathrm{~m}, 2 \mathrm{H}), 5.19-5.11(\mathrm{~m}, 2 \mathrm{H}), 4.26(\mathrm{dd}, J=12.3,5.8 \mathrm{~Hz}, 1 \mathrm{H}), 4.20(\mathrm{dd}, J=12.3$, $2.5 \mathrm{~Hz}, 1 \mathrm{H}$ ), 3.93 (ddd, $J=10.1,5.8,2.4 \mathrm{~Hz}, 1 \mathrm{H}), 2.09$ (s, 3H), 2.07 (s, 3H), 2.06 (s, 3H), 2.04 (s, 3H) ppm.

${ }^{13} \mathrm{C} \mathrm{NMR}\left(126 \mathrm{MHz}, \mathrm{CDCl}_{3}, 298 \mathrm{~K}, \delta\right): 191.6,170.8,170.3,169.6,169.4,157.4,138.1,130.5,126.1,123.9$, $115.3,98.8,72.8,72.5,71.2,68.4,62.1,20.78,20.74,20.73$ ppm.

HRMS-ESI (m/z) calculated for $\mathrm{C}_{21} \mathrm{H}_{24} \mathrm{O}_{11} \mathrm{Na}^{+}[\mathrm{M}+\mathrm{Na}]^{+}$, 475.1211; found, 475.1218; deviation: -1.55 ppm.

\section{D-Glucose derivative S3}<smiles>CC(=O)OC[C@H]1O[C@H](Oc2cccc(C=O)c2)[C@H](O[C@H](C)OC(C)=O)[C@@H](O)[C@@H]1O</smiles>

1.0 equiv. $\mathrm{NaH}_{2} \mathrm{PO}_{4}$

4.7 equiv. 2-methyl-2-butene 4.0 equiv. $\mathrm{NaClO}_{2}$

${ }^{t} \mathrm{BuOH} / \mathrm{H}_{2} \mathrm{O}(4 / 1, \mathrm{v} / \mathrm{v}), 23^{\circ} \mathrm{C}$ $88 \%$ yield<smiles>CC(=O)OC[C@H]1O[C@H](Oc2cccc(C(=O)O)c2)[C@H](OC(C)=O)[C@@H](OC(C)=O)[C@@H]1O</smiles> 
To a solution of D-glucose derivative $\mathbf{S} 2\left(317 \mathrm{mg}, 0.700 \mathrm{mmol}, 1.00\right.$ equiv.), $\mathrm{NaH}_{2} \mathrm{PO}_{4}$ (96.6 mg, $0.700 \mathrm{mmol}$, 1.00 equiv.) and 2-methyl-2-butene (231 mg, $350 \mu \mathrm{L}, 3.29 \mathrm{mmol}, 4.70$ equiv.) in ${ }^{t} \mathrm{BuOH} / \mathrm{H}_{2} \mathrm{O}(3.5 \mathrm{~mL}, 4 / 1, \mathrm{v} / \mathrm{v})$ was added $\mathrm{NaClO}_{2}(253 \mathrm{mg}, 2.80 \mathrm{mmol}, 4.00$ equiv.). After stirring at room temperature for $1 \mathrm{~h}$, the reaction mixture was acidified by $3 \mathrm{M} \mathrm{HCl}$ to $\mathrm{pH} 2-3$. The mixture was evaporated to dryness, and $10 \mathrm{~mL}$ of $\mathrm{H}_{2} \mathrm{O}$ was added to the residue. The resulting suspension was filtered, washed with $10 \mathrm{~mL}$ of $\mathrm{H}_{2} \mathrm{O}$ and $10 \mathrm{~mL}$ of DCM/hexanes (1/4, v/v). The solid was dried under vacuum to afford D-glucose derivative S3 (289 mg, 618 $\mu \mathrm{mol}, 88 \%$ yield) as a colorless solid.

$\mathbf{R} \boldsymbol{f}=0.25(\mathrm{EA} / \mathrm{DCM}=1 / 4, \mathrm{v} / \mathrm{v})$.

\section{NMR Spectroscopy:}

${ }^{1} \mathrm{H}$ NMR $\left(500 \mathrm{MHz}, \mathrm{CDCl}_{3}, 298 \mathrm{~K}, \delta\right): 7.83(\mathrm{dt}, J=7.7,1.2 \mathrm{~Hz}, 1 \mathrm{H}), 7.72(\mathrm{dd}, J=2.6,1.5 \mathrm{~Hz}, 1 \mathrm{H}), 7.41(\mathrm{t}$, $J=8.0 \mathrm{~Hz}, 1 \mathrm{H}), 7.24(\mathrm{ddd}, J=8.2,2.6,1.0 \mathrm{~Hz}, 1 \mathrm{H}), 5.36-5.27(\mathrm{~m}, 2 \mathrm{H}), 5.21-5.12(\mathrm{~m}, 2 \mathrm{H}), 4.27(\mathrm{dd}, J=$ 12.3, $5.7 \mathrm{~Hz}, 1 \mathrm{H}$ ), 4.21 (dd, $J=12.3,2.5 \mathrm{~Hz}, 1 \mathrm{H}$ ), 3.94 (ddd, $J=10.1,5.7,2.4 \mathrm{~Hz}, 1 \mathrm{H}$ ), 2.09 (s, 3H), 2.07 (s, 3H), $2.06(\mathrm{~s}, 3 \mathrm{H}), 2.04(\mathrm{~s}, 3 \mathrm{H}) \mathrm{ppm}$.

${ }^{13} \mathrm{C}$ NMR $\left(126 \mathrm{MHz} \mathrm{CDCl}_{3}, 298 \mathrm{~K}, \delta\right): 171.1,170.9,170.4,169.6,169.5,156.9,130.9,129.9,125.3,123.1$, $117.7,98.9,72.8,72.4,71.2,68.4,62.2,20.78,20.75,20.74$ ppm.

HRMS-ESI (m/z) calculated for $\mathrm{C}_{21} \mathrm{H}_{24} \mathrm{O}_{12} \mathrm{Na}^{+}[\mathrm{M}+\mathrm{Na}]^{+}$, 491.1160; found, 491.1168; deviation: -1.57 ppm.

(+)-Menthol derivative S4<smiles>O=Cc1cccc(C(=O)O)c1</smiles>

1.0 equiv.<smiles>CC(C)C1CCC([N+](=O)[O-])C[C@H]1O</smiles>

1.5 equiv.

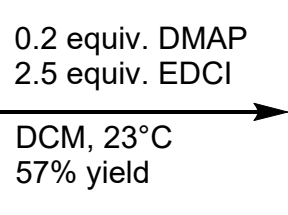

$\mathrm{DCM}, 23^{\circ} \mathrm{C}$
$57 \%$ yield

54

Under air, a $20 \mathrm{~mL}$ borosilicate vial was charged with a stirring bar, 3-formylbenzoic acid ( $375 \mathrm{mg}, 2.50 \mathrm{mmol}$, 1.00 equiv.), (+)-menthol (586 mg, $3.75 \mathrm{mmol}, 1.50$ equiv.), DMAP (61.1 mg, $0.5 \mathrm{mmol}, 0.200$ equiv.) and EDCl $\left(1.20 \mathrm{~g}, 6.25 \mathrm{mmol}, 2.50\right.$ equiv.). DCM $(10 \mathrm{~mL})$ was added via syringe, and the mixture was stirred at $23^{\circ} \mathrm{C}$ for $12 \mathrm{~h}$. Then the reaction mixture was evaporated to dryness, and the residue was purified by chromatography on silica gel $(E A / h e x a n e s=1 / 20, v / v)$ to afford $(+)$-menthol derivative $\mathbf{S 4}(412 \mathrm{mg}, 1.43 \mathrm{mmol}, 57 \%)$ as a colorless oil.

$\mathbf{R f}=0.24(\mathrm{EA} / \mathrm{hexanes}=1 / 25, \mathrm{v} / \mathrm{v})$

\section{NMR Spectroscopy:}

${ }^{1} \mathrm{H}$ NMR $\left(500 \mathrm{MHz}, \mathrm{CDCl}_{3}, 298 \mathrm{~K}, \delta\right): 10.07(\mathrm{~s}, 1 \mathrm{H}), 8.50$ (t, J = 1.8 Hz, 1H), 8.28 (dt, J = 7.7, 1.5 Hz, 1H), 8.05 (dt, $J=7.6,1.5 \mathrm{~Hz}, 1 \mathrm{H}), 7.60(\mathrm{t}, J=7.7 \mathrm{~Hz}, 1 \mathrm{H}), 4.96(\mathrm{td}, J=10.9,4.5 \mathrm{~Hz}, 1 \mathrm{H}), 2.14-2.06(\mathrm{~m}, 1 \mathrm{H})$, $1.98-1.87(\mathrm{~m}, 1 \mathrm{H}), 1.76-1.67(\mathrm{~m}, 2 \mathrm{H}), 1.60-1.49(\mathrm{~m}, 2 \mathrm{H}), 1.18-1.05(\mathrm{~m}, 2 \mathrm{H}), 0.91(\mathrm{~d}, J=12.4 \mathrm{~Hz}, 7 \mathrm{H})$, 
$0.78(\mathrm{~d}, J=7.0 \mathrm{~Hz}, 3 \mathrm{H}) \mathrm{ppm}$.

${ }^{13} \mathrm{C}$ NMR $\left(126 \mathrm{MHz}, \mathrm{CDCl}_{3}, 298 \mathrm{~K}, \delta\right):$ 191.5, 165.0, 136.6, 135.3, 133.0, 132.0, 131.3, 129.3, 75.6, 47.3, 41.0, 34.3, 31.6, 26.6, 23.7, 22.1, 20.9, $16.5 \mathrm{ppm}$.

HRMS-ESI (m/z) calculated for $\mathrm{C}_{18} \mathrm{H}_{24} \mathrm{O}_{3} \mathrm{Na}^{+}[\mathrm{M}+\mathrm{Na}]^{+}$, 311.1618; found, 311.1617; deviation: 0.24 ppm.

(+)-Menthol derivative S5<smiles>CC1CCC(C(C)C)[C@H](OC(=O)c2cccc(C=O)c2)C1</smiles>

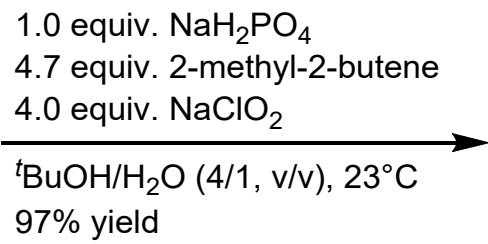

1.0 equiv. $\mathrm{NaH}_{2} \mathrm{PO}_{4}$ 4.7 equiv. 2-methyl-2-butene $97 \%$ yield<smiles>CC1CCC(C(C)C)[C@H](OC(=O)c2cccc(C(=O)O)c2)C1</smiles>

S5

To a solution of (+)-menthol derivative $\mathbf{S 4}$ (288 mg, $1.00 \mathrm{mmol}, 1.00$ equiv.), $\mathrm{NaH}_{2} \mathrm{PO}_{4}$ (138 mg, $1.00 \mathrm{mmol}$, 1.00 equiv.) and 2-methyl-2-butene (330 mg, $500 \mu \mathrm{L}, 4.70 \mathrm{mmol}, 4.70$ equiv.) in ${ }^{t} \mathrm{BuOH} / \mathrm{H}_{2} \mathrm{O}(5.0 \mathrm{~mL}, 4 / 1, \mathrm{v} / \mathrm{v})$ was added $\mathrm{NaClO}_{2}$ (362 mg, $4.00 \mathrm{mmol}, 4.00$ equiv.). After stirring at room temperature for $1 \mathrm{~h}$, the reaction mixture was acidified with $3 \mathrm{M} \mathrm{HCl}$ to $\mathrm{pH} 2-3$. The mixture was evaporated to dryness, and $10 \mathrm{~mL}$ of $\mathrm{H}_{2} \mathrm{O}$ was added. The resulting mixture was extracted with DCM $(3 \times$ ca. $20 \mathrm{~mL})$. The combined organic layer was dried over $\mathrm{Na}_{2} \mathrm{SO}_{4}$, filtered, and the solvent was removed under reduced pressure. The residue was purified by chromatography on silica gel (EA/hexanes, 1/5, v/v) to afford (+)-menthol derivative S5 (295 mg, 969 $\mu \mathrm{mol}, 97 \%$ yield) as a colorless solid.

$\mathbf{R} \boldsymbol{f}=0.49(\mathrm{EA} /$ hexanes $=1 / 4, \mathrm{v} / \mathrm{v})$

\section{NMR Spectroscopy:}

${ }^{1} \mathrm{H}$ NMR $\left(500 \mathrm{MHz}, \mathrm{CDCl}_{3}, 298 \mathrm{~K}, \delta\right): 12.12(\mathrm{brs}, 1 \mathrm{H}), 8.76(\mathrm{~s}, 1 \mathrm{H}), 8.30(\mathrm{~d}, J=1.8 \mathrm{~Hz}, 1 \mathrm{H}), 8.28(\mathrm{~d}, J=$ $1.8 \mathrm{~Hz}, 1 \mathrm{H}), 7.56(\mathrm{t}, J=7.8 \mathrm{~Hz}, 1 \mathrm{H}), 4.98(\mathrm{td}, J=10.9,4.4 \mathrm{~Hz}, 1 \mathrm{H}), 2.12(\mathrm{~d}, J=11.6 \mathrm{~Hz}, 1 \mathrm{H}), 2.02-1.87$ $(\mathrm{m}, 1 \mathrm{H}), 1.84-1.69(\mathrm{~m}, 2 \mathrm{H}), 1.63-1.48(\mathrm{~m}, 2 \mathrm{H}), 1.14(\mathrm{~d}, J=35.2 \mathrm{~Hz}, 2 \mathrm{H}), 0.93(\mathrm{~s}, 7 \mathrm{H}), 0.80(\mathrm{~d}, J=7.0 \mathrm{~Hz}$, 3H) ppm.

${ }^{13} \mathrm{C} \mathrm{NMR}\left(126 \mathrm{MHz}, \mathrm{CDCl}_{3}, 298 \mathrm{~K}, \delta\right): 171.6,165.3,134.8,134.3,131.6,131.4,129.8,128.8,75.6,47.3$, 41.0, 34.4, 31.6, 26.6, 23.7, 22.1, 20.9, 16.6 ppm.

HRMS-ESI (m/z) calculated for $\mathrm{C}_{18} \mathrm{H}_{23} \mathrm{O}_{4^{-}}[\mathrm{M}-\mathrm{H}]^{-}, 303.1602$; found, 303.1603; deviation: -0.35 ppm.

N-Succinimidyl 4-formylbenzoate (S6)

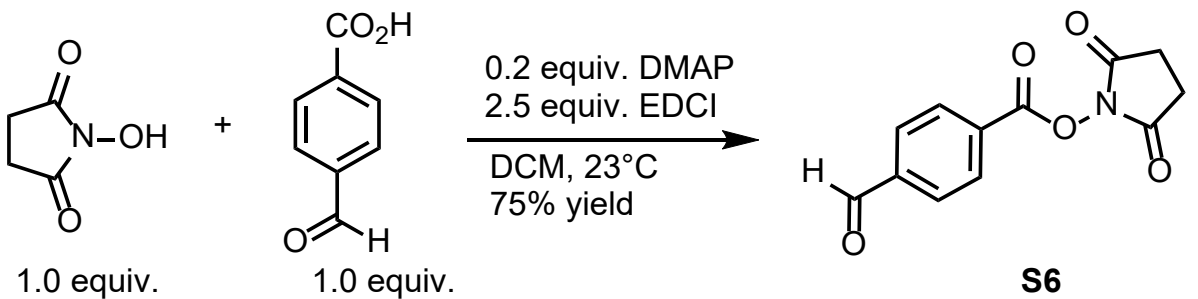


Under air, an oven-dried $100 \mathrm{~mL}$ round bottom flask was charged with a stirring bar, $N$-hydroxysuccinimide (1.15 g, 10.0 mmol, 1.00 equiv.), 4-formylbenzoic acid (1.50 g, 10.0 mmol, 1.00 equiv.), DMAP (244 mg, 2.00 mmol, 0.200 equiv.) and $\mathrm{EDCl}(4.79 \mathrm{~g}, 25.0 \mathrm{mmol}, 2.50$ equiv.). DCM (50 mL) was added via syringe, and the resulting mixture was stirred at $23{ }^{\circ} \mathrm{C}$ until the reaction competition was observed by TLC monitoring. After completion, the reaction mixture was evaporated to dryness, and the residue was purified by chromatography on silica gel (EA/DCM, 1/20, v/v) to afford $\mathrm{N}$-succinimidyl 4-formylbenzoate (S6) (1.85 g, $7.484 \mathrm{mmol}, 75 \%)$ as a colorless solid.

$\mathbf{R} \boldsymbol{f}=0.50(\mathrm{EA} / \mathrm{DCM}=1 / 9, \mathrm{v} / \mathrm{v})$

NMR Spectroscopy:

${ }^{1} \mathrm{H}$ NMR (500 MHz, $\left.\mathrm{CDCl}_{3}, 298 \mathrm{~K}, \delta\right): 10.12(\mathrm{~s}, 1 \mathrm{H}), 8.28$ (d, J = 8.4 Hz, 2H), 8.01 (d, J = 8.4 Hz, 2H), 2.92 (s, 4H) ppm.

${ }^{13} \mathrm{C}$ NMR (126 MHz, $\left.\mathrm{CDCl}_{3}, 298 \mathrm{~K}, \delta\right): 191.3,169.1,161.2,140.4,131.3,130.1,129.8,25.8$ ppm.

HRMS-Cl (Isobutane) (m/z) calculated for $\mathrm{C}_{12} \mathrm{H}_{10} \mathrm{NO}_{5}{ }^{+}[\mathrm{M}+\mathrm{H}]^{+}, 248.0553$; found, 248.0552; deviation: 0.52 ppm.

\section{N-Succinimidyl 4-carboxybenzoate (S7)}
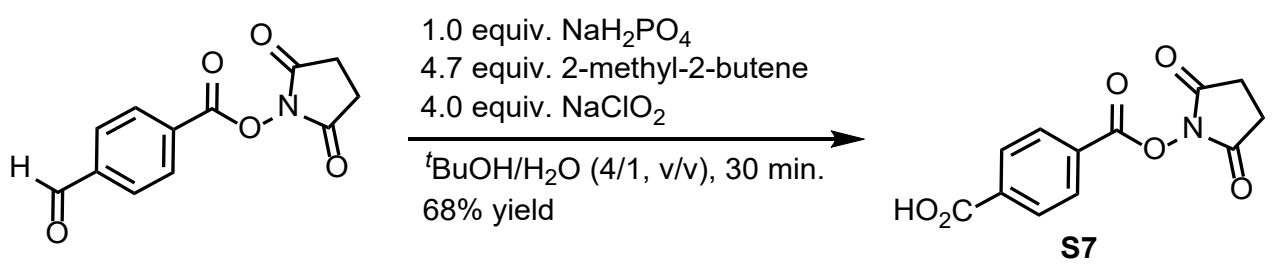

Under air, to a suspension of $\mathrm{N}$-succinimidyl 4-formylbenzoate (S6) (247 mg, $1.00 \mathrm{mmol}, 1.00$ equiv.), $\mathrm{NaH}_{2} \mathrm{PO}_{4}$ (138 mg, $1.00 \mathrm{mmol}, 1.00$ equiv.) and 2-methyl-2-butene (330 mg, $500 \mu \mathrm{L}, 4.70 \mathrm{mmol}, 4.70$ equiv.) in ${ }^{t} \mathrm{BuOH} / \mathrm{H}_{2} \mathrm{O}(10.0 \mathrm{~mL}, 4 / 1, \mathrm{v} / \mathrm{v})$ was added $\mathrm{NaClO}_{2}(362 \mathrm{mg}, 4.00 \mathrm{mmol}, 4.00$ equiv.). After stirring at room temperature for $30 \mathrm{~min}$, the reaction mixture was diluted with $50 \mathrm{~mL}$ of DCM and $10 \mathrm{~mL}$ of $\mathrm{H}_{2} \mathrm{O}$. The aqueous phase was acidified by $3 \mathrm{M} \mathrm{HCl}$ to $\mathrm{pH} 2-3$. The mixture was then transferred to a separatory funnel, and the layers were separated. The organic layer was separated and the aqueous layer was extracted with DCM $(3 \times$ ca. $20 \mathrm{~mL}$ ). The combined organic layer was washed with $20 \mathrm{~mL}$ of $\mathrm{H}_{2} \mathrm{O}$, dried over $\mathrm{Na}_{2} \mathrm{SO}_{4}$, filtered, and the solvent was removed under reduced pressure. The residue was washed with $\mathrm{Et}_{2} \mathrm{O}(5 \mathrm{~mL})$ and dried to afford $\mathrm{N}$-succinimidyl 4-carboxybenzoate (S7) (178 mg, $0.676 \mathrm{mmol}, 68 \%$ yield) as a colorless solid.

$\mathbf{R} \boldsymbol{f}=0.20(\mathrm{EA} / \mathrm{hexanes}=1 / 1, \mathrm{v} / \mathrm{v})$

\section{NMR Spectroscopy:}

${ }^{1} \mathrm{H}$ NMR (500 MHz, $\left.\left(\mathrm{CD}_{3}\right)_{2} \mathrm{SO}, 298 \mathrm{~K}, \delta\right): 13.58$ (brs, 1H), 8.23-8.19 (m, 2H), 8.18-8.15 (m, 2H), 2.91 (s, $4 \mathrm{H}) \mathrm{ppm}$.

${ }^{13} \mathrm{C}$ NMR $\left(126 \mathrm{MHz},\left(\mathrm{CD}_{3}\right)_{2} \mathrm{SO}, 298 \mathrm{~K}, \delta\right):$ 170.2, 166.2, 161.3, 136.7, 130.3, 130.2, 127.9, $25.6 \mathrm{ppm}$. 
HRMS-ESI (m/z) calculated for $\mathrm{C}_{12} \mathrm{H}_{8} \mathrm{NO}_{6}{ }^{-}$[M-H]', 262.0346; found, 262.0359; deviation: -5.02 ppm.

Fenofibrate derivative S8<smiles>C=Cc1ccc(C(=O)c2ccc(OC(C)(C)C(=O)OC(C)C)cc2)cc1</smiles>

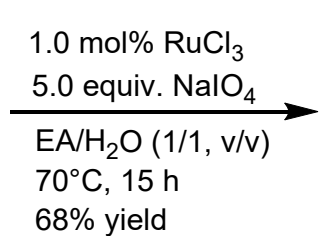<smiles>CC(C)OC(=O)C(C)(C)Oc1ccc(C(=O)c2ccc(C(=O)O)cc2)cc1</smiles>

S8

Under air, a $20 \mathrm{~mL}$ borosilicate vial was charged with isopropyl 2-methyl-2-(4-(4vinylbenzoyl)phenoxy)propanoate (S1) (352 mg, $1.00 \mathrm{mmol}, 1.00$ equiv.), NalO 4 (1.07 g, $5.00 \mathrm{mmol}, 5.00$ equiv.), $\mathrm{RuCl}_{3}\left(2.1 \mathrm{mg}, 1.00 \mu \mathrm{mol}, 0.01\right.$ equiv.), and $4 \mathrm{~mL} \mathrm{EA} / \mathrm{H}_{2} \mathrm{O}(1 / 1, \mathrm{v} / \mathrm{v})$. The reaction mixture was then heated to $70^{\circ} \mathrm{C}$ and stirred at the same temperature for 15 hours. After cooling to room temperature, the reaction mixture was diluted with $5 \mathrm{~mL}$ of $\mathrm{H}_{2} \mathrm{O}$ and $5 \mathrm{~mL}$ EA. The mixture was transferred to a separatory funnel, and the layers were separated. The organic layer was separated and the aqueous layer was extracted with EA $(3 \times$ ca. $30 \mathrm{~mL})$. The combined organic layer was dried over $\mathrm{Na}_{2} \mathrm{SO}_{4}$, filtered, and the solvent was removed under reduced pressure. The residue was purified by chromatography on silica gel (EA/hexanes $=1 / 6$ to $1 / 3$, $\mathrm{v} / \mathrm{v})$ to afford fenofibrate derivative $\mathbf{S} 8(253 \mathrm{mg}, 0.683 \mathrm{mmol}, 68 \%)$ as a colorless solid.

$\mathbf{R} \boldsymbol{f}=0.50(\mathrm{EA} / \mathrm{hexanes}=1 / 2, \mathrm{v} / \mathrm{v})$.

\section{NMR Spectroscopy:}

${ }^{1} \mathrm{H}$ NMR $\left(500 \mathrm{MHz}, \mathrm{CDCl}_{3}, 298 \mathrm{~K}, \delta\right): 8.22(\mathrm{~d}, J=8.5 \mathrm{~Hz}, 2 \mathrm{H}), 7.82(\mathrm{~d}, J=8.5 \mathrm{~Hz}, 2 \mathrm{H}), 7.77(\mathrm{~d}, J=8.9$ $\mathrm{Hz}, 2 \mathrm{H}), 6.88(\mathrm{~d}, J=8.9 \mathrm{~Hz}, 2 \mathrm{H}), 5.09(\mathrm{p}, J=6.3 \mathrm{~Hz}, 1 \mathrm{H}), 1.67$ (s, 6H), $1.21(\mathrm{~s}, 3 \mathrm{H}), 1.20$ (s, 3H) ppm.

${ }^{13} \mathrm{C} \mathrm{NMR}\left(126 \mathrm{MHz}, \mathrm{CDCl}_{3}, 298 \mathrm{~K}, \delta\right): 194.8,173.2,170.9,160.2,143.0,132.3,131.9,130.2,129.9,129.6$, $117.4,79.6,69.6,25.5,21.7 \mathrm{ppm}$.

HRMS-ESI (m/z) calculated for $\mathrm{C}_{21} \mathrm{H}_{23} \mathrm{O}_{6}{ }^{+}[\mathrm{M}+\mathrm{H}]^{+}, 371.1489$; found, 371.1489; deviation: $0.04 \mathrm{ppm}$.

\section{4-Fluorobenzoic acid derived oxime ester 33}<smiles>O=C(O)c1ccc(F)cc1</smiles>

1.0 equiv.<smiles>ON=C(c1ccccc1)c1ccccc1</smiles>

1.0 equiv.

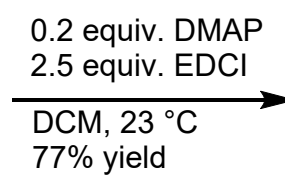

$77 \%$ yield

Under air, a $20 \mathrm{~mL}$ borosilicate vial was charged with 4-fluorobenzoic acid (140 mg, $1.00 \mathrm{mmol}, 1.00$ equiv.), diphenylmethanone oxime (197 mg, 1.00 mmol, 1.00 equiv.), DMAP (24.4 mg, 0.200 mmol, 0.200 equiv.), EDCl (479 mg, $2.50 \mathrm{mmol}, 2.00$ equiv.) and DCM $\left(5.0 \mathrm{~mL}\right.$ ). The resulting mixture was stirred at $23^{\circ} \mathrm{C}$ until the reaction competition was observed by TLC monitoring. The entire mixture was transferred into a separatory funnel containing $10 \mathrm{~mL}$ water and $10 \mathrm{~mL} \mathrm{DCM}$, and the layers were separated. The DCM layer was collected, and the aqueous layer was further extracted with DCM $(3 \times$ ca. $15 \mathrm{~mL})$. The combined organic layer was dried over 
$\mathrm{Na}_{2} \mathrm{SO}_{4}$, filtered, and the solvent was removed under reduced pressure. The residue was purified by chromatography on silica gel $(E A /$ hexanes $=1 / 4$ to $1 / 2, v / v)$ to afford 4 -fluorobenzoic acid derived oxime ester 33 (245 mg, $0.767 \mathrm{mmol}, 77 \%)$ as a colorless solid.

$\mathbf{R} \boldsymbol{f}=0.55(\mathrm{EA} / \mathrm{hexanes}=1 / 4, \mathrm{v} / \mathrm{v})$

\section{NMR Spectroscopy:}

${ }^{1} \mathrm{H}$ NMR (500 MHz, $\left.\mathrm{CD}_{2} \mathrm{Cl}_{2}, 298 \mathrm{~K}, \delta\right): 7.58-7.48(\mathrm{~m}, 2 \mathrm{H}), 7.38(\mathrm{~d}, J=7.2 \mathrm{~Hz}, 2 \mathrm{H}), 7.26-7.23(\mathrm{~m}, 3 \mathrm{H})$, $7.20(\mathrm{t}, J=7.4 \mathrm{~Hz}, 1 \mathrm{H}), 7.15-7.10(\mathrm{~m}, 4 \mathrm{H}), 6.76(\mathrm{t}, J=8.7 \mathrm{~Hz}, 2 \mathrm{H}) \mathrm{ppm}$.

${ }^{13} \mathrm{C}$ NMR $\left(126 \mathrm{MHz}, \mathrm{CD}_{2} \mathrm{Cl}_{2}, 298 \mathrm{~K}, \delta\right): 166.2(\mathrm{~d}, J=254.4 \mathrm{~Hz}), 162.8,165.8,135.0,133.0,132.5(\mathrm{~d}, J=$ $9.5 \mathrm{~Hz}), 131.4,130.1,129.3,129.1,128.9,128.7,125.6$ (d, J = 2.9 Hz), 116.0 (d, J = 22.1 Hz) ppm.

${ }^{19} \mathrm{~F}$ NMR (471 MHz, $\left.\mathrm{CD}_{2} \mathrm{Cl}_{2}, 298 \mathrm{~K}, \delta\right):-105.4(\mathrm{~m}) \mathrm{ppm}$.

HRMS-ESI (m/z) calculated for $\mathrm{C}_{20} \mathrm{H}_{14} \mathrm{NO}_{2} \mathrm{FNa}^{+}[\mathrm{M}+\mathrm{Na}]^{+}, 342.0901$; found, 342.0902; deviation: -0.22 ppm.

\section{Mechanistic Studies}

\section{Cyclic voltammograms}

Cyclic voltammograms were recorded using an Autolab PGSTAT204 potentiostat and a Pt working electrode, a $\mathrm{Ag} / \mathrm{AgCl}$ reference electrode and a Pt sheet auxiliary electrode. The voltammograms were recorded at room temperature in $0.1 \mathrm{M}$ tetrabutylammonium hexafluorophosphate in $\operatorname{MeCN}(3 \mathrm{~mL})$ containing tetrabutylammonium 4-fluorobenzoate $\left(\mathrm{TBA}^{+}\left[3^{-\mathrm{H}}\right]^{-}\right)(11.4 \mathrm{mg}, 0.030 \mathrm{mmol})$. The scan rate was $100 \mathrm{mV} \mathrm{s}^{-1}$. $E_{\mathrm{ox}}=1.51 \mathrm{~V}$ vs. $\mathrm{Ag} / \mathrm{AgCl}$ in $\mathrm{MeCN}$ was observed. Thus, for deprotonated 3, $E_{\mathrm{ox}}=1.47 \mathrm{~V}$ vs. SCE in MeCN was obtained.

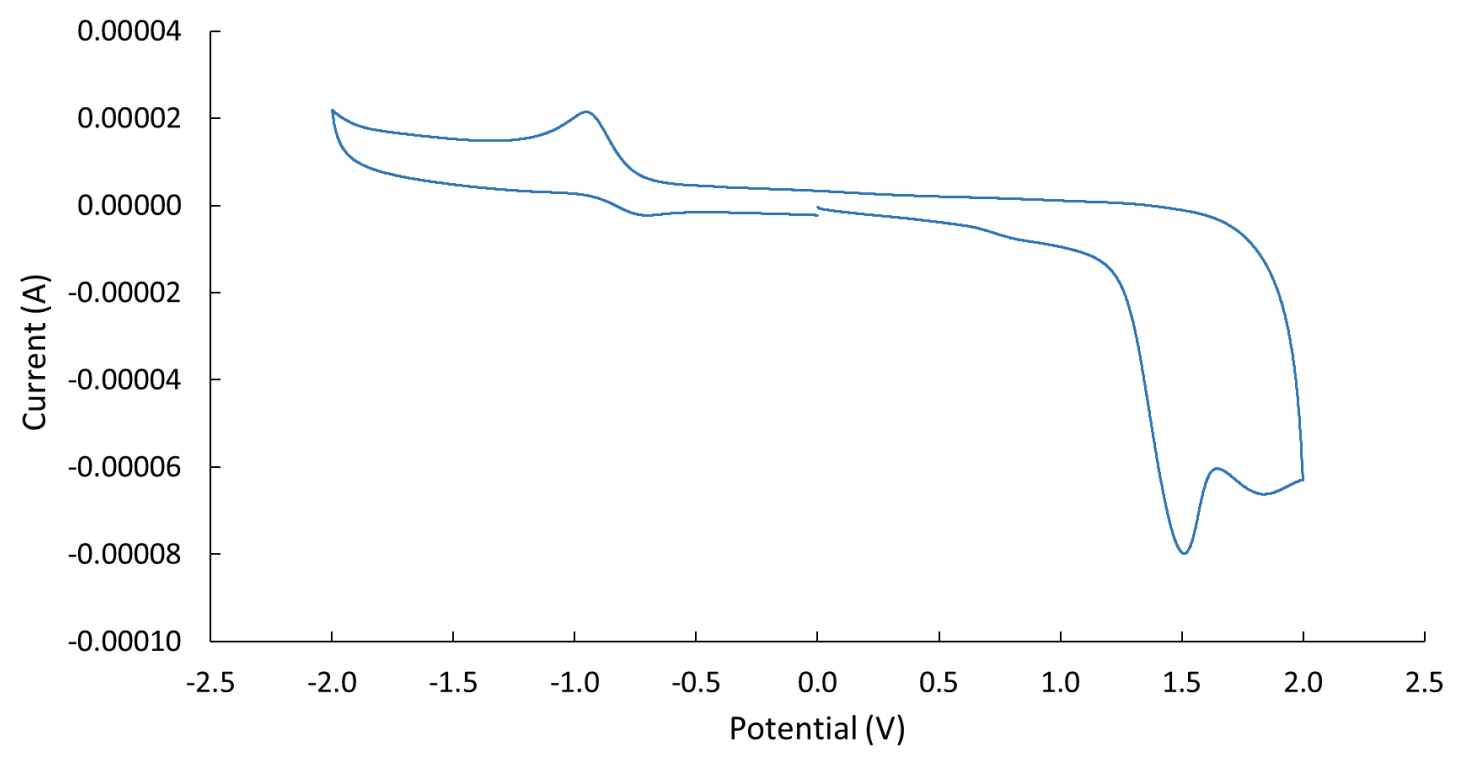

Figure S18. Cyclic voltammetry of tetrabutylammonium 4-fluorobenzoate in $\mathrm{MeCN}$. 


\section{UV-vis Absorption Spectrum}

All UV-vis measurements were recorded on a Shimadzu UV-vis Spectrophotometer UV-2600 with temperature controller using a screw-top quartz cuvette (Hellma fluorescence quartz cuvette, $10 \times 10 \mathrm{~mm}, 3.5 \mathrm{~mL}$ ). Samples were prepared in a glovebox and then taken out of the glovebox. UV-vis spectra of 4-fluorobenzoic acid (3, 1 $\mathrm{mM}), \mathrm{Cu}(\mathrm{MeCN})_{4} \mathrm{BF}_{4}(2.5 \mathrm{mM}), \mathrm{Cu}(\mathrm{OTf})_{2}(2.5 \mathrm{mM}), \mathrm{TBAF} \cdot\left({ }^{(} \mathrm{BuOH}\right)_{4}(2.5 \mathrm{mM})$, the mixture of $\mathrm{Cu}(\mathrm{OTf})_{2}(2.5 \mathrm{mM})$ + TBAF $\cdot\left({ }^{t} \mathrm{BuOH}\right)_{4}(2.5 \mathrm{mM})$, the mixture of $3(1 \mathrm{mM})+\mathrm{Cu}(\mathrm{OTf})_{2}(2.5 \mathrm{mM})$, the mixture of $3(1 \mathrm{mM})+$ TBAF $\left({ }^{(} \mathrm{BuOH}\right)_{4}(2.5 \mathrm{mM})$, the mixture of $\mathrm{TBA}^{+}[3-\mathrm{H}]^{-}(1 \mathrm{mM})$ and $\mathrm{Cu}(\mathrm{OTf})_{2}(2.5 \mathrm{mM})$, the mixture of $3(1 \mathrm{mM})+$ $\mathrm{Cu}(\mathrm{OTf})_{2}(2.5 \mathrm{mM})+\mathrm{TBAF} \cdot\left({ }^{t} \mathrm{BuOH}\right)_{4}(2.5 \mathrm{mM})$, and the mixture of $3(1 \mathrm{mM})+\mathrm{Cu}(\mathrm{OTf})_{2}(2.5 \mathrm{mM})+$ $\mathrm{Cu}(\mathrm{MeCN})_{4} \mathrm{BF}_{4}(2.5 \mathrm{mM})+\mathrm{TBAF} \cdot\left({ }^{(} \mathrm{BuOH}\right)_{4}(2.5 \mathrm{mM})$ were recorded respectively, using $\mathrm{MeCN}$ as the solvent. The mixture of $3(1 \mathrm{mM})+\mathrm{Cu}(\mathrm{OTf})_{2}(2.5 \mathrm{mM})+\mathrm{TBAF} \cdot(\mathrm{t} \mathrm{BuOH})_{4}(2.5 \mathrm{mM})$, the mixture of TBA ${ }^{+}[3-\mathrm{H}]^{-}(1 \mathrm{mM})$ and $\mathrm{Cu}(\mathrm{OTf})_{2}(2.5 \mathrm{mM})$, and the mixture of $3(1 \mathrm{mM})+\mathrm{Cu}(\mathrm{OTf})_{2}(2.5 \mathrm{mM})+\mathrm{Cu}(\mathrm{MeCN})_{4} \mathrm{BF}_{4}(2.5 \mathrm{mM})+$ TBAF· $\left({ }^{(} \mathrm{BuOH}\right)_{4}(2.5 \mathrm{mM})$ have significant absorbance from 370 to $470 \mathrm{~nm}$. All samples containing $\mathrm{Cu}(\mathrm{OTf})_{2}$ $(2.5 \mathrm{mM})$ show a strong absorbance from 550 to $900 \mathrm{~nm}$.

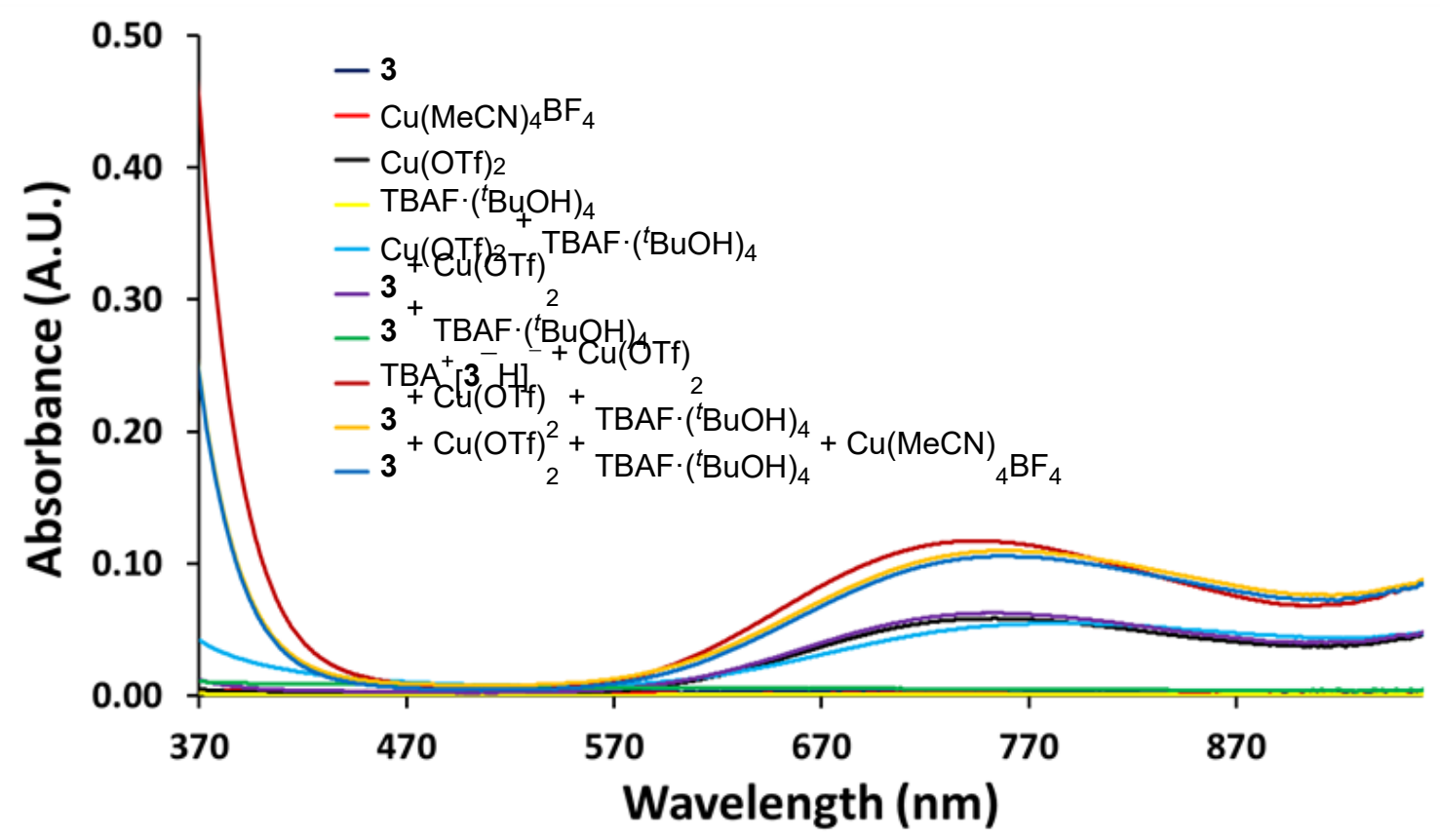

Figure S19. UV-vis spectra analysis of the reaction components.

Photolysis of the mixture of 3, $\mathrm{Cu}(\mathrm{OTf})_{2}$, and TBAF·(tBuOH $)_{4}$

In a nitrogen-filled glovebox, a mixture of $3(1 \mathrm{mM}), \mathrm{Cu}(\mathrm{OTf})_{2}(2.5 \mathrm{mM})$ and TBAF·( $\left.{ }^{t} \mathrm{BuOH}\right)_{4}(2.5 \mathrm{mM})$ in $2.5 \mathrm{~mL}$ $\mathrm{MeCN}$ was transferred to a screw-top quartz cuvette (Hellma fluorescence quartz cuvette, $10 \times 10 \mathrm{~mm}, 3.5$ $\mathrm{mL}$ ). The quartz cuvette was sealed and taken out of the glovebox. The absorption spectra were recorded on a Shimadzu UV-vis Spectrophotometer UV-2600 after the cuvette was irradiated by two Kessil PR160-390 nm LEDs ( $5 \mathrm{~cm}$ away from two Kessil PR160-390 nm LEDs, and the temperature was maintained at approximately $35^{\circ} \mathrm{C}$ through cooling with a fan) for various time $(0.0 \mathrm{~min}, 0.5 \mathrm{~min}, 1.0 \mathrm{~min}, 2.0 \mathrm{~min}, 4.0 \mathrm{~min}$, and $8.0 \mathrm{~min})$. 


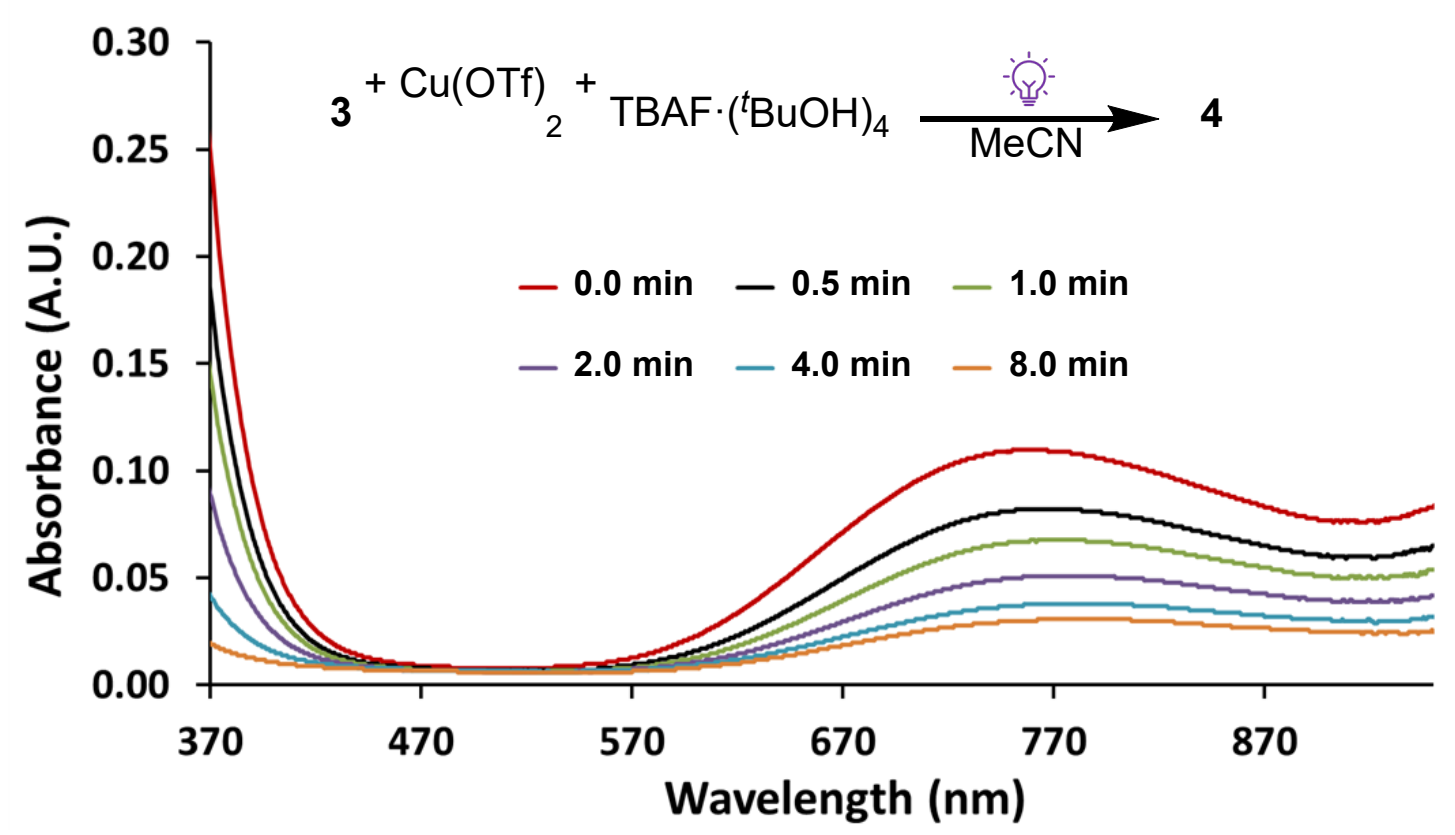

Figure S20. UV-vis spectra of the photolyzed mixture of 3, $\mathrm{Cu}(\mathrm{OTf})_{2}$, and TBAF·(tBuOH $)_{4}$ in $\mathrm{CH}_{3} \mathrm{CN}$.

After photolysis, $0.5 \mathrm{~mL}$ reaction mixture was taken out and diluted with $\mathrm{CD}_{3} \mathrm{CN}$, and the formation of 1,4difluorobenzene (4) was confirmed by ${ }^{19} \mathrm{~F}$ NMR. Upon addition of 2,2'-biquinoline $(3.8 \mathrm{mg})$ to the rest of the reaction mixture, the colourless solution turned to dark purple colour, which originates from the formation of a purple [Cu'(biq) $]^{+}$complex. ${ }^{5-8} 0.25 \mathrm{~mL}$ of the above purple reaction mixture was taken out and further diluted to $2.5 \mathrm{~mL}$ with $\mathrm{MeCN}$. The absorption spectrum was recorded on a UV-vis spectrophotometer, and a significant absorbance $\left(\lambda_{\max }=546 \mathrm{~nm}\right)$ was observed. A control experiment showed that addition of 2,2'-biquinoline (3.8 $\mathrm{mg})$ to the unphotolyzed reaction mixture of $3(1 \mathrm{mM}), \mathrm{Cu}(\mathrm{OTf})_{2}(2.5 \mathrm{mM})$ and TBAF·( $\left.\mathrm{BuOH}\right)_{4}(2.5 \mathrm{mM})$ in $\operatorname{MeCN}(2.0 \mathrm{~mL})$ led to a yellow-green reaction mixture with a precipitate that was ascribed to $\left[\mathrm{Cu}^{\prime \prime}(\mathrm{biq})_{2}\right]^{2+}$ complex $^{6-8}$. The mixture was then diluted with $\mathrm{MeCN}(18.0 \mathrm{~mL})$ to dissolve all precipitate, and the absorption spectrum was recorded on a UV-vis spectrophotometer. No significant absorbance was observed at around $\lambda$ $=546 \mathrm{~nm}$. Note: $\left[\mathrm{Cu}^{\prime \prime}(\text { biq })_{2}\right]^{2+}$ is known to be sensitive to reductants, and its reduction results in the formation of purple $\left[\mathrm{Cu}^{\prime}(\mathrm{biq})_{2}\right]^{+}$complex. ${ }^{6-8}$ In the above control experiment, we found that using MeCN stored in a plastic wash bottle or transferring solutions with plastic syringes would slowly result in a slightly purple reaction mixture with a significant absorbance $\left(\lambda_{\max }=546 \mathrm{~nm}\right)$, which possibly originates from the reduction of $\left[\mathrm{Cu}^{\prime \prime}(\mathrm{biq})_{2}\right]^{2+}$ to $\left[\mathrm{Cu}^{\prime}(\mathrm{biq})_{2}\right]^{+}$by a trace amount of reducing impurities from plastics. Thus, quartz cuvette, glass pipettes, and vials were rinsed with newly opened HPLC gradient grade MeCN (from Sigma-Aldrich) and dried before use. Newly opened HPLC gradient grade MeCN (from Sigma-Aldrich) stored in a glass bottle was used to dilute the reaction mixture, and all solutions were transferred with glass pipettes. 

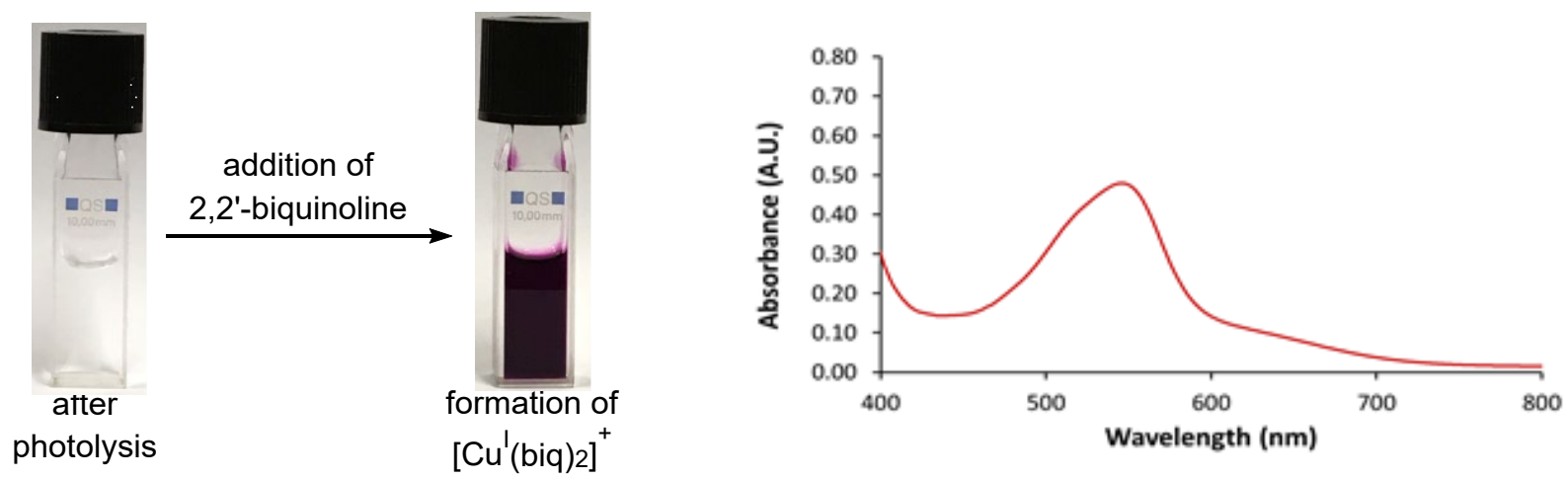

Figure S21. Confirmation of the formation of $\mathrm{Cu}(\mathrm{I})$. Formation of purple $\left[\mathrm{Cu}^{\prime}(\mathrm{biq})_{2}\right]^{+}$complex (left) and UV-vis spectra of $\left[\mathrm{Cu}^{\prime}(\mathrm{biq})_{2}\right]^{+}$complex (right).

\section{Radical trapping experiments}

\section{Reaction with $\mathrm{Cu}(\mathrm{MeCN})_{4} \mathrm{BF}_{4}$}

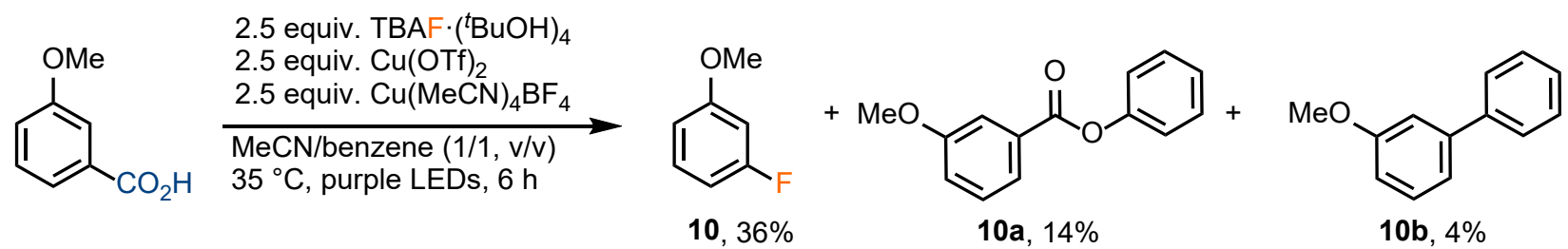

In a nitrogen-filled glovebox, a $16 \mathrm{~mL}$ borosilicate vial equipped with a magnetic stir bar was charged with 3methoxybenzoic acid (30.4 mg, $0.200 \mathrm{mmol}, 1.00$ equiv.), Cu(OTf) 2 (181 mg, $0.500 \mathrm{mmol}, 2.50$ equiv.), $\mathrm{Cu}(\mathrm{MeCN})_{4} \mathrm{BF}_{4}$ (157 mg, $0.500 \mathrm{mmol}, 2.50$ equiv.), and TBAF.( $\left.{ }^{\mathrm{BuOH}}\right)_{4}(279 \mathrm{mg}, 0.500 \mathrm{mmol}, 2.50$ equiv.). MeCN $(4.0 \mathrm{~mL})$ and benzene $(4.0 \mathrm{~mL})$ were then added into the vial. The vial was sealed with a Teflon cap, taken out of the glovebox and placed $5 \mathrm{~cm}$ away from two purple LEDs (Kessil PR160-390 nm LEDs). The vial was first pre-stirred for 30 min without irradiation, then placed $5 \mathrm{~cm}$ away from two $390 \mathrm{~nm}$ Kessil LEDs. The temperature was kept at approximately $35{ }^{\circ} \mathrm{C}$ through cooling with a fan. After being irradiated for $6 \mathrm{~h}, 2-$ fluorotoluene (22.0 mg, $22.0 \mu \mathrm{L}, 0.200 \mathrm{mmol}, 1.00$ equiv.) was added as an internal standard. The reaction mixture was diluted with $\mathrm{CD}_{3} \mathrm{CN}$, and the yield of 1-fluoro-3-methoxybenzene (10) was determined by ${ }^{19} \mathrm{~F}$ NMR integration relative to the internal standard (36\% yield, standard: $\delta-119.4(\mathrm{~m}) \mathrm{ppm}$, and 10: $\delta-113.6(\mathrm{~m}) \mathrm{ppm})$. The NMR sample was recycled and recombined with the remaining reaction mixture. The resulting mixture was transferred to a $25 \mathrm{~mL}$ round-bottom flask and evaporated to dryness. The desidue was dissolved in DCM (20 $\mathrm{mL}$ ), transferred into a separatory funnel containing $5 \mathrm{~mL}$ saturated aqueous $\mathrm{NH}_{4} \mathrm{Cl}$ and $5 \mathrm{~mL} \mathrm{H}_{2} \mathrm{O}$, and the layers were separated. The organic layer was collected, and the aqueous layer was further extracted with DCM $\left(3 \times\right.$ ca. $20 \mathrm{~mL}$ ). The combined organic layer was dried over $\mathrm{Na}_{2} \mathrm{SO}_{4}$, filtered, and the solvent was removed under reduced pressure. The residue was purified by chromatography on silica gel (EA/pentane $=1 / 100$ to $1 / 50, \mathrm{v} / \mathrm{v})$ to afford phenyl 3-methoxybenzoate (10a) $(6.2 \mathrm{mg}, 27 \mu \mathrm{mol}, 14 \%)$ as a colorless solid and 3-methoxy1,1'-biphenyl (10b) $(1.3 \mathrm{mg}, 7 \mu \mathrm{mol}, 4 \%)$ as a slightly yellow oil.

1-Fluoro-3-methoxybenzene (10) 


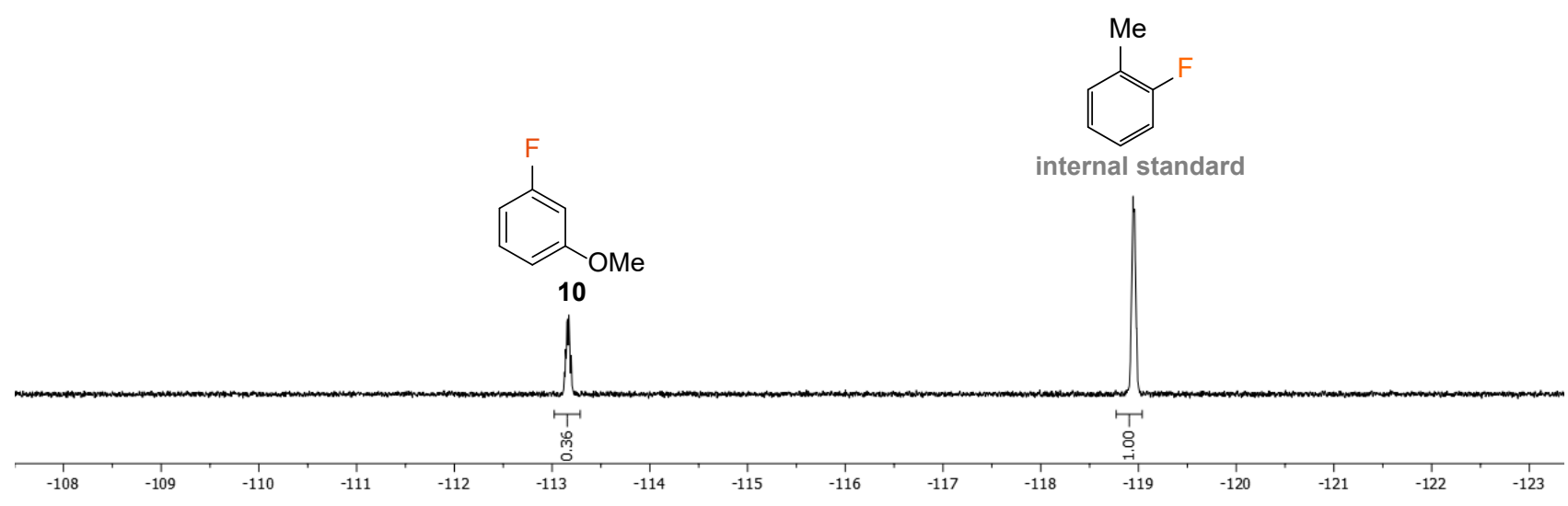

Figure S22. ${ }^{19} \mathrm{~F}$ NMR of resulting mixtures for product 10 under the reaction condition without $\mathrm{Cu}(\mathrm{MeCN}) \mathrm{BF}_{4}$.

Phenyl 3-methoxybenzoate (10a):

$\mathbf{R} \boldsymbol{f}=0.24(\mathrm{EA} / \mathrm{hexanes}, 1 / 50, \mathrm{v} / \mathrm{v})$.

\section{NMR Spectroscopy:}

${ }^{1} \mathrm{H}$ NMR $\left(500 \mathrm{MHz}, \mathrm{CDCl}_{3}, 298 \mathrm{~K}, \delta\right): 7.82(\mathrm{dt}, J=7.7,1.2 \mathrm{~Hz}, 1 \mathrm{H}), 7.71(\mathrm{dd}, J=2.7,1.5 \mathrm{~Hz}, 1 \mathrm{H}), 7.48-$ $7.37(\mathrm{~m}, 3 \mathrm{H}), 7.28$ (t, $J=7.5 \mathrm{~Hz}, 1 \mathrm{H}), 7.24-7.21(\mathrm{~m}, 2 \mathrm{H}), 7.18$ (ddd, $J=8.3,2.7,1.0 \mathrm{~Hz}, 1 \mathrm{H}), 3.89(\mathrm{~s}, 3 \mathrm{H})$ ppm.

${ }^{13} \mathrm{C}$ NMR $\left(126 \mathrm{MHz}, \mathrm{CDCl}_{3}, 298 \mathrm{~K}, \delta\right): 165.2,159.8,151.1,131.0,129.7,129.6,126.1,122.7,121.8,120.3$, 114.6, 55.7 ppm.

HRMS-EI (m/z) calculated for $\mathrm{C}_{14} \mathrm{H}_{12} \mathrm{O}_{3}{ }^{+}[\mathrm{M}]^{+}, 228.0781$; found, 228.0781; deviation: $0.02 \mathrm{ppm}$.

3-Methoxy-1,1'-biphenyl (10b):

$\mathbf{R} \boldsymbol{f}=0.37(\mathrm{EA} / \mathrm{hexanes}, 1 / 50, \mathrm{v} / \mathrm{v})$.

\section{NMR Spectroscopy:}

${ }^{1} \mathrm{H}$ NMR (500 MHz, $\left.\mathrm{CDCl}_{3}, 298 \mathrm{~K}, \delta\right): 7.61-7.58(\mathrm{~m}, 2 \mathrm{H}), 7.46-7.42(\mathrm{~m}, 2 \mathrm{H}), 7.39-7.32(\mathrm{~m}, 2 \mathrm{H}), 7.19$ (ddd, $J=7.6,1.7,0.9 \mathrm{~Hz}, 1 \mathrm{H}), 7.13(\mathrm{dd}, J=2.6,1.7 \mathrm{~Hz}, 1 \mathrm{H}), 6.90(\mathrm{ddd}, J=8.2,2.6,1.0 \mathrm{~Hz}, 1 \mathrm{H}), 3.87(\mathrm{~s}, 3 \mathrm{H})$ ppm.

${ }^{13} \mathrm{C} \mathrm{NMR}\left(126 \mathrm{MHz}, \mathrm{CDCl}_{3}, 298 \mathrm{~K}, \delta\right): 160.1,142.9,141.3,129.9,128.9,127.6,127.4,119.8,113.1,112.8$, $55.5 \mathrm{ppm}$.

HRMS-EI (m/z) calculated for $\mathrm{C}_{13} \mathrm{H}_{12} \mathrm{O}^{+}[\mathrm{M}]^{+}$, 184.0883; found, 184.0884; deviation: -0.68 ppm.

\section{Reaction without $\mathrm{Cu}(\mathrm{MeCN}){ }_{4} \mathrm{BF}_{4}$}


<smiles>COc1cccc(C(=O)O)c1</smiles>

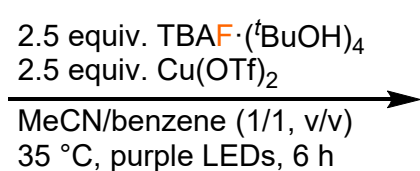

$35^{\circ} \mathrm{C}$, purple LEDs, $6 \mathrm{~h}$<smiles>COc1cccc(F)c1</smiles>

$10,25 \%$<smiles></smiles>

$10 \mathrm{a}, 21 \%$<smiles>COc1cccc(-c2ccccc2)c1</smiles>

$10 \mathrm{~b}, 9 \%$

In a nitrogen-filled glovebox, a $16 \mathrm{~mL}$ borosilicate vial equipped with a magnetic stir bar was charged with 3methoxybenzoic acid (30.4 mg, 0.200 mmol, 1.00 equiv.), Cu(OTf) 2 (181 mg, $0.500 \mathrm{mmol}, 2.50$ equiv.), and TBAF·( $\left.{ }^{(} \mathrm{BuOH}\right)_{4}(279 \mathrm{mg}, 0.500 \mathrm{mmol}, 2.50$ equiv. $)$. MeCN $(4.0 \mathrm{~mL})$ and benzene $(4.0 \mathrm{~mL})$ were then added into the vial. The vial was sealed with a Teflon cap, taken out of the glovebox and placed $5 \mathrm{~cm}$ away from two purple LEDs (Kessil PR160-390 nm LEDs). The vial was first pre-stirred for 30 min without irradiation, then placed $5 \mathrm{~cm}$ away from two $390 \mathrm{~nm}$ Kessil LEDs. The temperature was kept at approximately $35^{\circ} \mathrm{C}$ through cooling with a fan. After being irradiated for $6 \mathrm{~h}, 2$-fluorotoluene $(22.0 \mathrm{mg}, 22.0 \mu \mathrm{L}, 0.200 \mathrm{mmol}, 1.00$ equiv.) was added as an internal standard. The reaction mixture was diluted with $\mathrm{CD}_{3} \mathrm{CN}$, and the yield of 1-fluoro-3methoxybenzene (10) was determined by ${ }^{19} \mathrm{~F}$ NMR integration relative to the internal standard (25\% yield, standard: $\delta-119.4(\mathrm{~m}) \mathrm{ppm}$, and 10: $\delta-113.6(\mathrm{~m}) \mathrm{ppm})$. The NMR sample was recycled and recombined with the remaining reaction mixture. The resulting mixture was transferred to a $25 \mathrm{~mL}$ round-bottom flask and evaporated to dryness. The desidue was dissolved in DCM $(20 \mathrm{~mL})$, transferred into a separatory funnel containing $5 \mathrm{~mL}$ saturated aqueous $\mathrm{NH}_{4} \mathrm{Cl}$ and $5 \mathrm{~mL} \mathrm{H} 2 \mathrm{O}$, and the layers were separated. The organic layer was collected, and the aqueous layer was further extracted with DCM $(3 \times$ ca. $20 \mathrm{~mL})$. The combined organic layer was dried over $\mathrm{Na}_{2} \mathrm{SO}_{4}$, filtered, and the solvent was removed under reduced pressure. The residue was purified by chromatography on silica gel (EA/pentane $=1 / 100$ to $1 / 50, \mathrm{v} / \mathrm{v})$ to afford phenyl 3-methoxybenzoate (10a) (9.8 mg, $43 \mu \mathrm{mol}, 21 \%)$ as a colorless solid and 3-methoxy-1,1'-biphenyl (10b) (3.3 mg, $18 \mu \mathrm{mol}, 9 \%)$ as a slightly yellow oil.

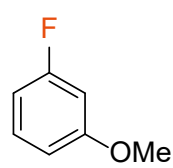

10

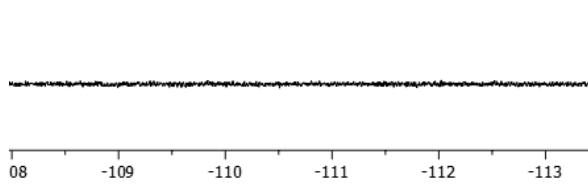

Figure S23. ${ }^{19} \mathrm{~F}$ NMR of resulting mixtures for product 10 under the reaction condition without $\mathrm{Cu}(\mathrm{MeCN}) \mathrm{BF}_{4}$. 
Radical cyclisation experiment
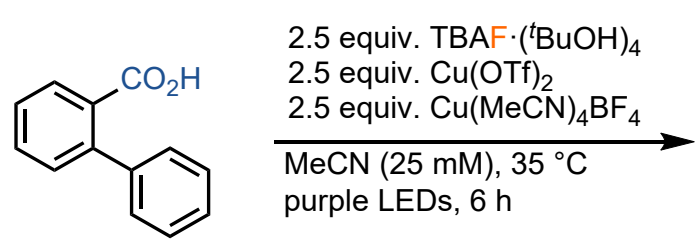

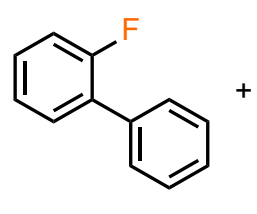

$31,9 \%$<smiles>O=c1oc2ccccc2c2ccccc12</smiles>

$32,88 \%$

In a nitrogen-filled glovebox, a $16 \mathrm{~mL}$ borosilicate vial equipped with a magnetic stir bar was charged with [1,1'biphenyl]-2-carboxylic acid (39.6 mg, $0.200 \mathrm{mmol}, 1.00$ equiv.), $\mathrm{Cu}(\mathrm{OTf})_{2}$ (181 mg, $0.500 \mathrm{mmol}, 2.50$ equiv.), $\mathrm{Cu}(\mathrm{MeCN})_{4} \mathrm{BF}_{4}$ (157 mg, $0.500 \mathrm{mmol}, 2.50$ equiv.), and TBAF.( $\left.{ }^{\mathrm{B} u O H}\right)_{4}(279 \mathrm{mg}, 0.500 \mathrm{mmol}, 2.50$ equiv.). $\operatorname{MeCN}(8.0 \mathrm{~mL}, \mathrm{C}=25 \mathrm{mM})$ was then added into the vial. The vial was sealed with a Teflon cap, taken out of the glovebox and placed $5 \mathrm{~cm}$ away from two purple LEDs (Kessil PR160-390 nm LEDs). The vial was first pre-stirred for $30 \mathrm{~min}$ without irradiation, then placed $5 \mathrm{~cm}$ away from two $390 \mathrm{~nm}$ Kessil LEDs. The temperature was kept at approximately $35^{\circ} \mathrm{C}$ through cooling with a fan. After being irradiated for $6 \mathrm{~h}, 2$-fluorotoluene (22.0 $\mathrm{mg}, 22.0 \mu \mathrm{L}, 0.200 \mathrm{mmol}, 1.00$ equiv.) was added as an internal standard. The reaction mixture was diluted with $\mathrm{CD}_{3} \mathrm{CN}$, and the yield of violate 2-fluoro-1,1'-biphenyl (31) was determined by ${ }^{19} \mathrm{~F}$ NMR integration relative to the internal standard (9\% yield, standard: $\delta-119.4(\mathrm{~m}) \mathrm{ppm}$, and 31: $\delta-119.9(\mathrm{~m}) \mathrm{ppm})$. The NMR sample was recycled and recombined with the remaining reaction mixture. The resulting mixture was transferred to a $25 \mathrm{~mL}$ round-bottom flask and evaporated to dryness. The desidue was dissolved in DCM $(20 \mathrm{~mL})$, transferred into a separatory funnel containing $5 \mathrm{~mL}$ saturated aqueous $\mathrm{NH}_{4} \mathrm{Cl}$ and $5 \mathrm{~mL} \mathrm{H} \mathrm{H}_{2} \mathrm{O}$, and the layers were separated. The organic layer was collected, and the aqueous layer was further extracted with DCM $(3 \times$ ca. 20 $\mathrm{mL}$ ). The combined organic layer was dried over $\mathrm{Na}_{2} \mathrm{SO}_{4}$, filtered, and the solvent was removed under reduced pressure. The residue was purified by chromatography on silica gel $(E A /$ pentane $=1 / 9, \mathrm{v} / \mathrm{v})$ to afford $6 \mathrm{H}$ benzo[c]chromen-6-one (32) (34.4 mg, $175 \mu \mathrm{mol}, 88 \%$ ) as a colorless solid.

2-Fluoro-1,1'-biphenyl (31)

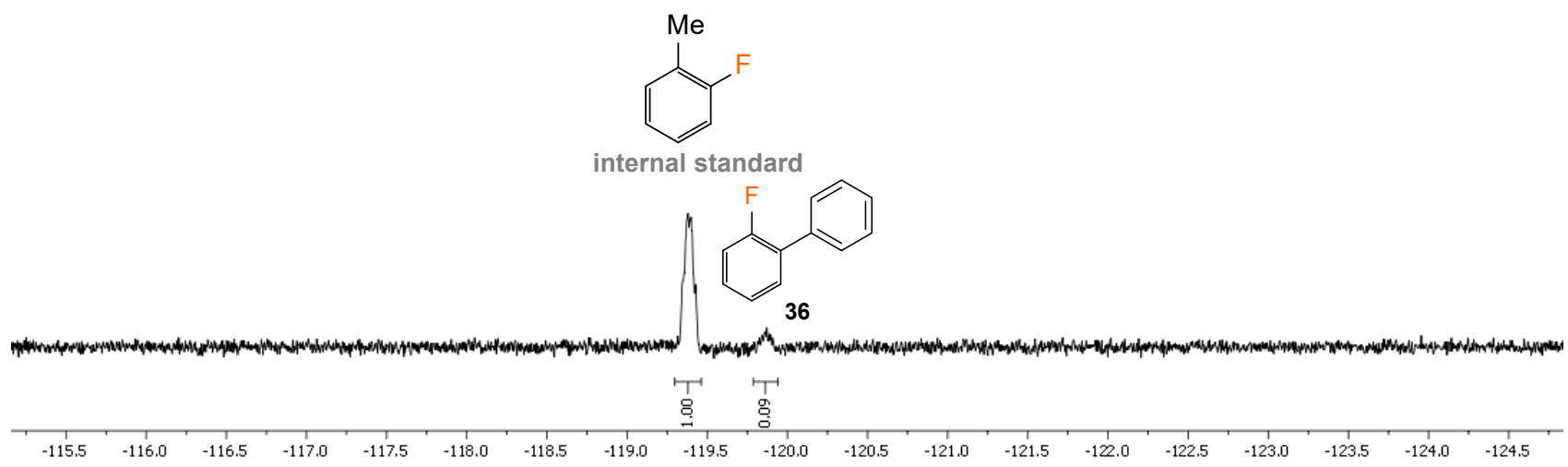

Figure S24. ${ }^{19} \mathrm{~F}$ NMR of the resulting mixtures for product 36. 


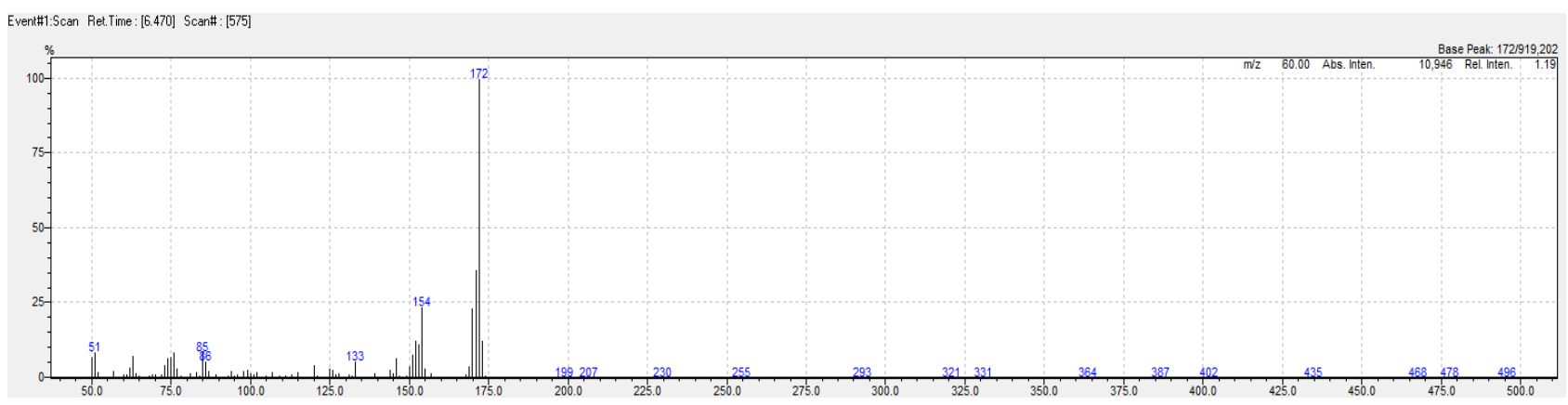

Figure S25. Mass spectrum of product $\mathbf{3 6}$ peak from GCMS

6H-Benzo[c]chromen-6-one (32):

$\boldsymbol{R} \boldsymbol{f}=0.30($ EA/pentane, $1 / 9, \mathrm{v} / \mathrm{v})$.

\section{NMR Spectroscopy:}

${ }^{1} \mathrm{H}$ NMR $\left(300 \mathrm{MHz}, \mathrm{CDCl}_{3}, 298 \mathrm{~K}, \delta\right): 8.26$ (dd, $\left.J=7.9,1.6 \mathrm{~Hz}, 1 \mathrm{H}\right), 7.94$ (ddd, $\left.J=18.2,8.1,1.3 \mathrm{~Hz}, 2 \mathrm{H}\right)$, 7.75-7.63 (m, 1H), 7.45 (ddd, $J=8.2,7.3,1.1 \mathrm{~Hz}, 1 \mathrm{H}$ ), 7.35 (ddd, $J=8.4,6.9,1.6 \mathrm{~Hz}, 1 \mathrm{H}$ ), 7.21 (ddd, $J$ $=8.3,7.6,1.2 \mathrm{~Hz}, 2 \mathrm{H}) \mathrm{ppm}$.

${ }^{13} \mathrm{C}$ NMR $\left(75 \mathrm{MHz}, \mathrm{CDCl}_{3}, 298 \mathrm{~K}, \delta\right): 161.2,151.3,134.9,134.8,130.6,130.5,128.9,124.6,122.8,121.7$, $121.3,118.0,117.8 \mathrm{ppm}$.

HRMS-El (m/z) calculated for $\mathrm{C}_{13} \mathrm{H}_{8} \mathrm{O}_{2}{ }^{+}[\mathrm{M}]^{+}, 196.0519$; found, 196.0521; deviation: $-1.27 \mathrm{ppm}$.

Decarboxylative fluorination of 4-fluorobenzoic acid derived oxime ester 33.

\section{Reaction with $\mathrm{Cu}(\mathrm{MeCN})_{4} \mathrm{BF}_{4}$}
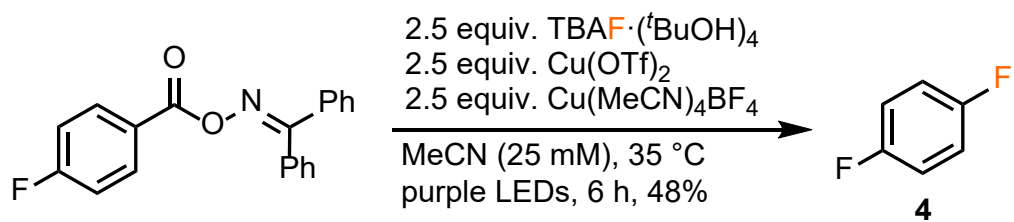

In a nitrogen-filled glovebox, a $16 \mathrm{~mL}$ borosilicate vial equipped with a magnetic stir bar was charged with 4fluorobenzoic acid derived oxime ester 33 (63.9 mg, 0.200 mmol, 1.00 equiv.), Cu(OTf)2 (181 mg, 0.500 mmol, 2.50 equiv.), $\mathrm{Cu}(\mathrm{MeCN})_{4} \mathrm{BF}_{4}$ (157 mg, $0.500 \mathrm{mmol}, 2.50$ equiv.), and TBAF·( $\left.{ }^{t} \mathrm{BuOH}\right)_{4}(279 \mathrm{mg}, 0.500 \mathrm{mmol}$, 2.50 equiv.). $\mathrm{MeCN}(8.0 \mathrm{~mL}, \mathrm{c}=25 \mathrm{mM}$ ) was then added into the vial. The vial was sealed with a Teflon cap, taken out of the glovebox and placed $5 \mathrm{~cm}$ away from two purple LEDs (Kessil PR160-390 $\mathrm{nm}$ LEDs). The vial was first pre-stirred for $30 \mathrm{~min}$ without irradiation, then placed $5 \mathrm{~cm}$ away from two $390 \mathrm{~nm}$ Kessil LEDs. The temperature was kept at approximately $35{ }^{\circ} \mathrm{C}$ through cooling with a fan. After being irradiated for $6 \mathrm{~h}, 2-$ fluorotoluene (22.0 mg, $22.0 \mu \mathrm{L}, 0.200 \mathrm{mmol}, 1.00$ equiv.) was added as an internal standard. The reaction mixture was diluted with $\mathrm{CD}_{3} \mathrm{CN}$, and the yield of 1,4-difluorobenzene (4) was determined by ${ }^{19} \mathrm{~F} N M R$ integration relative to the internal standard (48\% yield, standard: $\delta-119.4(\mathrm{~m}) \mathrm{ppm}$, and 4: $\delta-121.1(\mathrm{~m}) \mathrm{ppm}$ ). Besides, side products fluorobenzene (4a) and 4-fluorophenyl 4-fluorobenzoate (4b) were also observed in $4 \%$ 
and $18 \%$ yield, respectively.

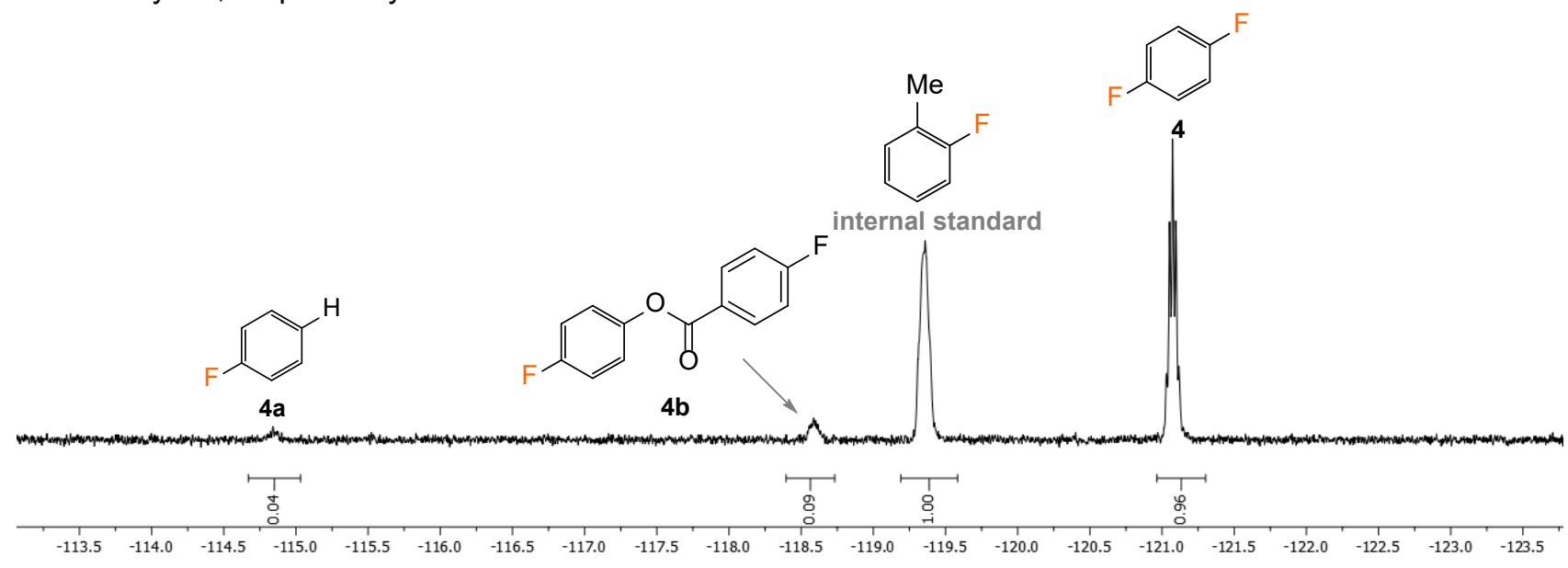

Figure S26. ${ }^{19} \mathrm{~F}$ NMR of the resulting mixtures for product 4 from 4-fluorobenzoic acid derived oxime ester $\mathbf{3 3}$ under reaction condition with $\mathrm{Cu}(\mathrm{MeCN}) \mathrm{BF}_{4}$.

\section{Reaction without $\mathrm{Cu}(\mathrm{MeCN})_{4} \mathrm{BF}_{4}$}

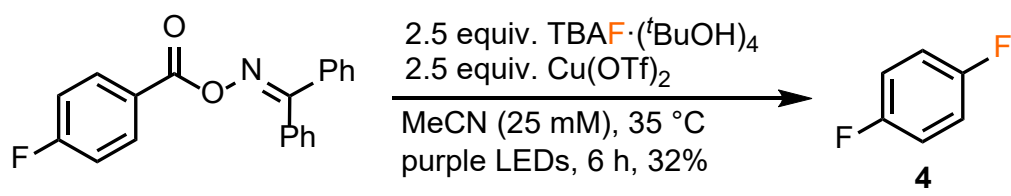

In a nitrogen-filled glovebox, a $16 \mathrm{~mL}$ borosilicate vial equipped with a magnetic stir bar was charged with 4fluorobenzoic acid derived oxime ester 33 (63.9 mg, $0.200 \mathrm{mmol}, 1.00$ equiv.), Cu(OTf)2 (181 mg, $0.500 \mathrm{mmol}$, 2.50 equiv.), and TBAF·( $\left.{ }^{t} \mathrm{BuOH}\right)_{4}(279 \mathrm{mg}, 0.500 \mathrm{mmol}, 2.50$ equiv. $)$ MeCN $(8.0 \mathrm{~mL}, \mathrm{c}=25 \mathrm{mM})$ was then added into the vial. The vial was sealed with a Teflon cap, taken out of the glovebox and placed $5 \mathrm{~cm}$ away from two purple LEDs (Kessil PR160-390 nm LEDs). The vial was first pre-stirred for 30 min without irradiation, then placed $5 \mathrm{~cm}$ away from two $390 \mathrm{~nm}$ Kessil LEDs. The temperature was kept at approximately $35{ }^{\circ} \mathrm{C}$ through cooling with a fan. After being irradiated for $6 \mathrm{~h}$, 2-fluorotoluene $(22.0 \mathrm{mg}, 22.0 \mu \mathrm{L}, 0.200 \mathrm{mmol}, 1.00$ equiv.) was added as an internal standard. The reaction mixture was diluted with $\mathrm{CD}_{3} \mathrm{CN}$, and the yield of 1,4difluorobenzene (4) was determined by ${ }^{19} \mathrm{~F}$ NMR integration relative to the internal standard $(32 \%$ yield, standard: $\delta-119.4(\mathrm{~m}) \mathrm{ppm}$, and 4: $\delta-121.1(\mathrm{~m}) \mathrm{ppm})$. Besides, side products fluorobenzene (4a) and 4fluorophenyl 4-fluorobenzoate (4b) were also observed in $12 \%$ and $8 \%$ yield, respectively. 


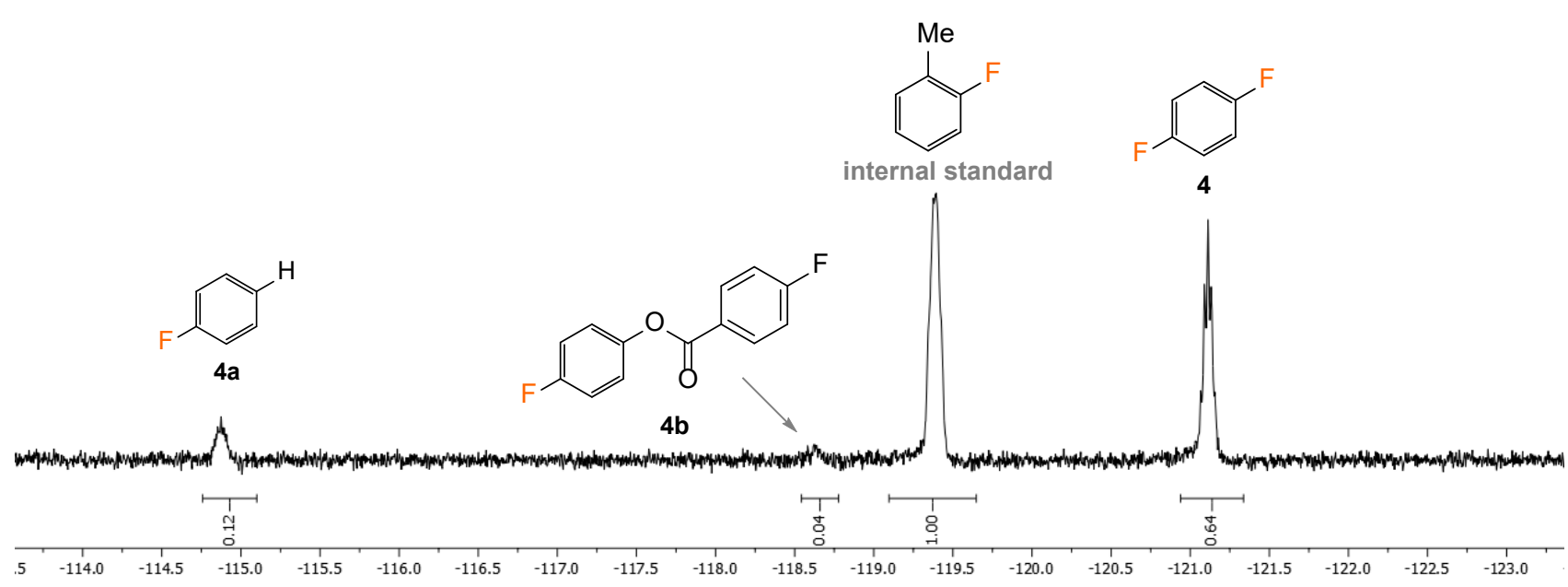

Figure S27. ${ }^{19} \mathrm{~F}$ NMR of the resulting mixtures for product 4 from 4-fluorobenzoic acid derived oxime ester 33 under the condition without $\mathrm{Cu}(\mathrm{MeCN}) \mathrm{BF}_{4}$.

\section{Quantum yield measurement}

\section{Determination of the light intensity of Kessil PR160-390 nm LEDs}

Standard ferrioxalate actinometry ${ }^{9,10}$ was used to determine the photon flux of Kessil PR160-390 nm LEDs. A solution of ferrioxalate $(0.15 \mathrm{M})$ was prepared by dissolving potassium ferrioxalate trihydrate $(737 \mathrm{mg}, 1.50$ $\mathrm{mmol}$ ) in $10.0 \mathrm{~mL}$ of $0.20 \mathrm{M}$ aqueous $\mathrm{H}_{2} \mathrm{SO}_{4}$. A buffered solution of 1,10-phenanthroline $(0.15 \mathrm{M})$ was prepared by dissolving NaOAc $(1.23 \mathrm{~g}, 15.0 \mathrm{mmol})$ and 1,10-phenanthroline $(541 \mathrm{mg}, 3.00 \mathrm{mmol})$ in $20 \mathrm{~mL}$ of $0.20 \mathrm{M}$ aqueous $\mathrm{H}_{2} \mathrm{SO}_{4}$.

To a 4-mL borosilicate vial equipped with a stir bar was added $1.0 \mathrm{~mL}$ of the ferrioxalate solution. The vial was sealed with a Teflon cap and placed $5 \mathrm{~cm}$ away from two Kessil PR160-390 nm LEDs. After being irradiated for 20 seconds, $0.5 \mathrm{~mL}$ of the reaction mixture was taken out immediately and injected into a 4-mL borosilicate vial containing $1.5 \mathrm{~mL}$ of the aqueous sulfuric acid and $2.0 \mathrm{~mL}$ of the buffered solution. The resulting mixture was then allowed to rest for 1 hour to allow the formed ferrous ions to react completely with 1,10-phenanthroline. An aliquot $(25 \mu \mathrm{L})$ of the resulting solution was diluted with $3.0 \mathrm{~mL}$ of $0.20 \mathrm{M}$ aqueous sulfuric acid, and the absorbance in a cuvette $(I=1.0 \mathrm{~cm})$ at $510 \mathrm{~nm}$ was measured by UV-Vis spectrometer. The above procedure was repeated four more times, and the average absorption was used for the calculation of photon flux. A nonirradiated sample was also prepared and the absorbance at $510 \mathrm{~nm}$ was measured.

The photon flux was calculated as follows:

$$
\mathrm{mol} \mathrm{Fe} \mathrm{F}^{2+}=\frac{V \times \Delta A(510 \mathrm{~nm})}{l \times \varepsilon}
$$

where $V$ is the total volume $(0.96 \mathrm{~L})$ of the solution that was analyzed, $\Delta A(0.583)$ is the difference between the average absorption of irradiated and non-irradiated solutions at $510 \mathrm{~nm}, /$ is the path length $(1.00 \mathrm{~cm})$, and $\varepsilon$ is the molar absorptivity of the ferrioxalate actinometer at $510 \mathrm{~nm}\left(11,100 \mathrm{~L} \mathrm{~mol}^{-1} \mathrm{~cm}^{-1}\right)$.

The photon flux was calculated as follows: 


$$
\text { photon flux }=\frac{\mathrm{mol} \mathrm{Fe}^{2+}}{\Phi \times t \times f}
$$

where $\Phi$ is the quantum yield for the ferrioxalate actinometer (approximated as $1.13^{11}$, which was reported at $\lambda=392 \mathrm{~nm}), t$ is the irradiation time (20 s), and $f$ is the fraction of light absorbed at $\lambda=390 \mathrm{~nm}$ by the ferrioxalate actinometer. This value is calculated using the following equation where $A(390 \mathrm{~nm})$ is the absorption of the ferrioxalate solution at $390 \mathrm{~nm}$. An absorption spectrum gave an $A(390 \mathrm{~nm})$ value of $>3$, indicating that the fraction of absorbed light $(f)$ is $>0.999$.

$$
f=1-10^{-A(390 \mathrm{~mm})}
$$

The average photon flux was thus calculated to be $2.23 \times 10^{-6}$ einsteins $\mathrm{s}^{-1}$

\section{Determination of quantum yield}<smiles>CC(=O)OC[C@H]1O[C@H](Oc2cccc(C(=O)O)c2)[C@H](O)[C@@H](OC(C)=O)[C@@H]1O</smiles>

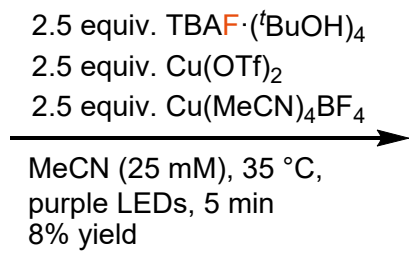

$8 \%$ yield

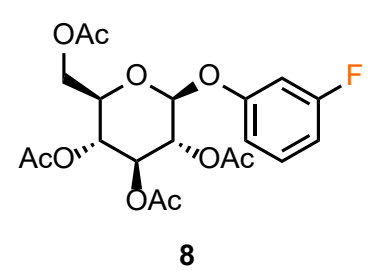

8

In a nitrogen-filled glovebox, a $4 \mathrm{~mL}$ borosilicate vial equipped with a magnetic stir bar was charged with $\mathrm{D}$ glucose derivative $\mathbf{S 3}$ (11.7 mg, $25.0 \mu \mathrm{mol}, 1.00$ equiv.), $\mathrm{Cu}(\mathrm{OTf})_{2}$ (22.6 mg, $62.5 \mu \mathrm{mol}, 2.50$ equiv.), $\mathrm{Cu}(\mathrm{MeCN})_{4} \mathrm{BF}_{4}(19.7 \mathrm{mg}, 62.5 \mu \mathrm{mol}, 2.50$ equiv. $)$, and TBAF·( $\left.{ }^{+} \mathrm{BuOH}\right)_{4}(34.9 \mathrm{mg}, 62.5 \mu \mathrm{mol}, 2.50$ equiv.). MeCN $(1.0 \mathrm{~mL}, \mathrm{c}=25 \mathrm{mM})$ was then added into the vial. The vial was sealed with a Teflon cap, taken out of the glovebox and placed $5 \mathrm{~cm}$ away from two purple LEDs (Kessil PR160-390 nm LEDs). The reaction mixture was stirred without irradiation for $30 \mathrm{~min}$ at ambient temperature and then irradiated for $5 \mathrm{~min}$ while maintaining the temperature at approximately $35^{\circ} \mathrm{C}$ through cooling with a fan. After being irradiated for $5 \mathrm{~min}$, the reaction mixture was cooled to room temperature. 2-fluorotoluene ( $5.5 \mathrm{mg}, 5.5 \mu \mathrm{L}, 50 \mu \mathrm{mol}, 2.00$ equiv.) was added as an internal standard. The reaction mixture was diluted with $\mathrm{CD}_{3} \mathrm{CN}$, and the ${ }^{19} \mathrm{~F}$ NMR spectrum was measured. The yield of product D-glucose derivative $(8,2.00 \mu \mathrm{mol}, 8 \%$ yield, $\delta-112.8(\mathrm{~m}) \mathrm{ppm})$ was determined by ${ }^{19} \mathrm{~F}$ NMR integration relative to the internal standard $(\delta-119.4(\mathrm{~m}) \mathrm{ppm})$.

The quantum yield was calculated as follows:

$$
\Phi=\frac{\text { mol product }}{\text { photon flux } \times t \times f}
$$

where mol product is the amount of product $8\left(2 \times 10^{-6} \mathrm{~mol}\right)$, photon flux is determined by above ferrioxalate actinometry $\left(2.23 \times 10^{-6}\right.$ einsteins $\left.\mathrm{s}^{-1}\right), t$ is the reaction time (300 s), and $f$ is the fraction of light absorbed by the reaction mixture at $390 \mathrm{~nm}$. This value is calculated using the following equation where $A(390 \mathrm{~nm})$ is the absorption of the non-irradiated reaction mixture $(0.963)$ at $390 \mathrm{~nm}$. (Note: the reaction mixture was pre-stirred for $30 \mathrm{~min}$ without irradiation, and the resulting solution was filtered through a $13 \mathrm{~mm}$ syringe filter before measuring the absorption septrum). The fraction of light absorbed at $390 \mathrm{~nm}$ was calculated: 


$$
f=1-10^{-A(390 \mathrm{~nm})}=1-10^{-0.963}=0.891
$$

Thus, the quantum yield was calculated as $\Phi=3.36 \times 10^{-3}$. The relatively low quantum yield indicates that there are several possible pathways for energy dissipation including radiationless deactivation of the excited copper(II) carboxylates and back electron transfer (BET) between the generated aryl carboxyl radical and copper(I) species.

\section{REFERENCES}

1. Fulmer, G. R.; Miller, A. J. M.; Sherden, N. H.; Gottlieb, H. E.; Nudelman, A.; Stoltz, B. M.; Bercaw, J. E.; Goldberg, K. I. NMR Chemical Shifts of Trace Impurities: Common Laboratory Solvents, Organics, and Gases in Deuterated Solvents Relevant to the Organometallic Chemist. Organometallics 2010, 29, 21762179.

2. Kim, D. W.; Jeong, H.-J.; Lim, S. T; Sohn, M.-H. Tetrabutylammonium Tetra(tert-Butyl Alcohol)-Coordinated Fluoride as a Facile Fluoride Source. Angew. Chem. Int. Ed. 2008, 47, 8404-8406.

3. Lill, A.; Scholich, K.; Stark, H. Synthesis of Novel Dansyl-Labeled Celecoxib Derivatives. Tetrahedron Lett. 2013, 54, 6682-6686.

4. Mato, M.; Herlé, B.; Echavarren, A. M. Cyclopropanation by Gold- or Zinc-Catalyzed Retro-Buchner Reaction at Room Temperature. Org. Lett. 2018, 20, 4341-4345.

5. Kunkely, H.; Vogler, A. Photoredox Reactivity of Copper(II)-3,5-diisopropylsalicylate Induced by Ligand-toMetal Charge Transfer Excitation of the Copper-Phenolate Chromophore. Inorganica. Chimica. Acta. 2004, 357, 888-890.

6. Ichiishi, N.; Canty, A.; Yates, B. F.; Sanford, M. S. Mechanistic Investigations of Cu-Catalyzed Fluorination

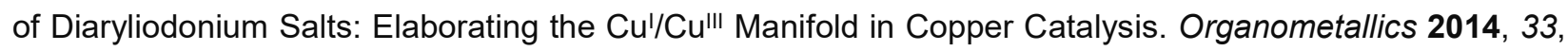
5525-5534.

7. Breckenridge, J. G.; Lewis, R. W.; Quick, L. A. 2:2'-Biquinolyl-a Reagent for Copper. Can. J. Res. Sect. B $1939,17,258-265$.

8. Ali, B. F.; Al-Sou'od, K.; Al-Jaar, N.; Nassar, A.; Zaghal, M. H.; Judeh, Z.; Al-Far, R.; Al-Refai, M.; Ibrahim, M.; Mansi, K.; Al-Obaidi, K. H. Interconversion of Copper(II) to Copper(I): Synthesis, Characterization of Copper(II) and Copper(I) 2,2'-Biquinoline Complexes and Their Microbiological Activity. J. Coord. Chem. 2006, 59, 229-241.

9. Kuhn, H. J.; Braslavsky, S. E.; Schmidt, R. Chemical Actinometry (IUPAC Technical Report). Pure Appl. Chem. 2004, 76, 2105-2146.

10. Cismesia, M. A.; Yoon, T. P. Characterizing Chain Processes in Visible Light Photoredox Catalysis. Chem. Sci. 2015, 6, 5426-5434.

11. Wegner, Ernst E.; Arthur W. Adamson. Photochemistry of Complex lons. III. Absolute Quantum Yields for the Photolysis of Some Aqueous Chromium (III) Complexes. Chemical Actinometry in the Long Wavelength Visible Region. J. Am. Chem. Soc.1966, 88, 394-404. 


\section{SPECTROSCOPIC DATA}

\section{${ }^{1} \mathrm{H}$ NMR of mavacoxib (2)}

$\mathrm{CD}_{2} \mathrm{Cl}_{2}, 298 \mathrm{~K}$
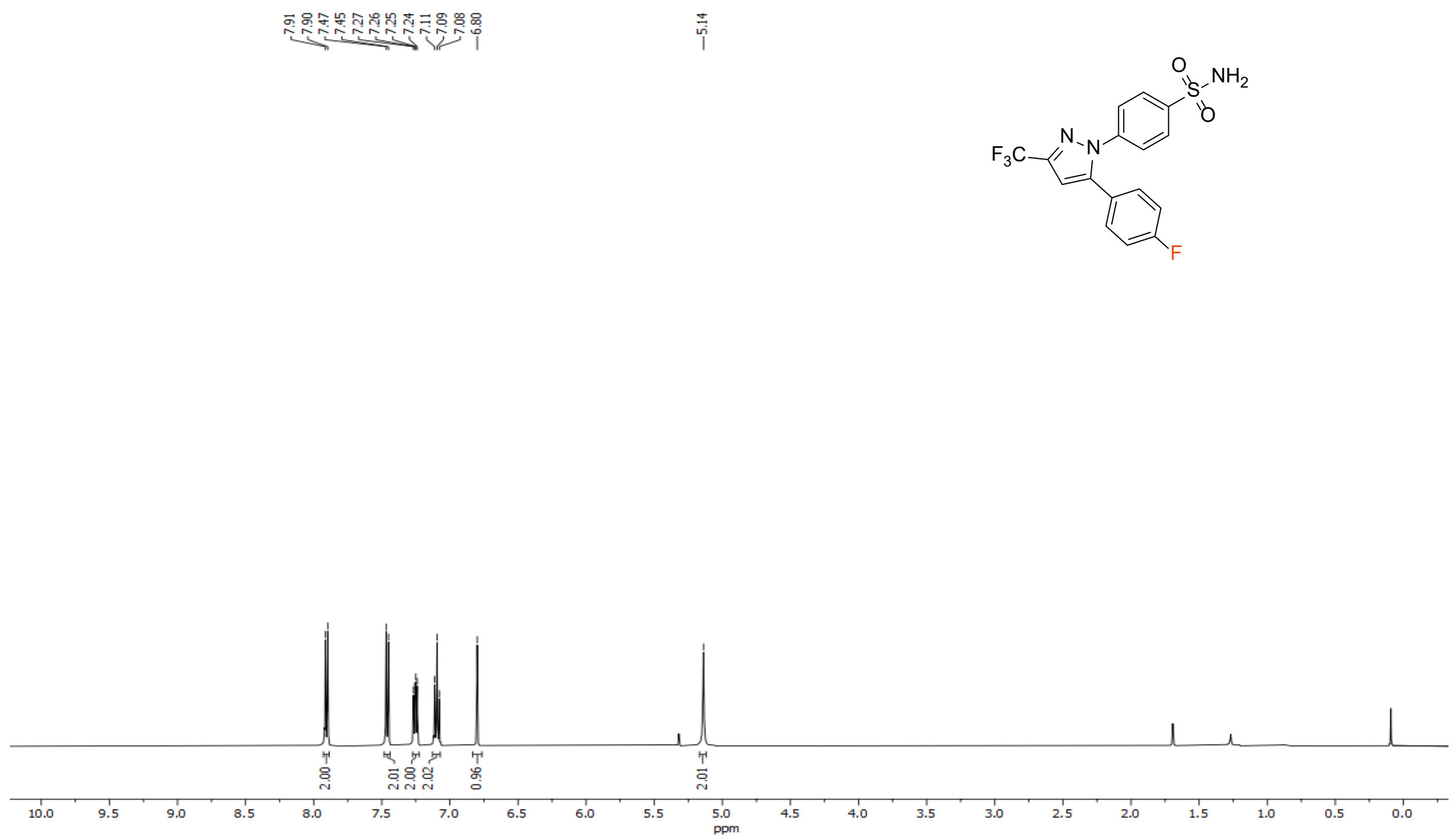
${ }^{13} \mathrm{C}$ NMR of mavacoxib (2)

$\mathrm{CD}_{2} \mathrm{Cl}_{2}, 298 \mathrm{~K}$

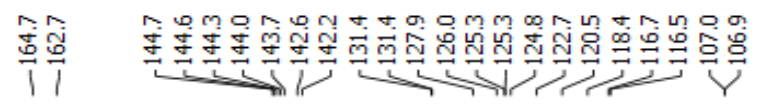

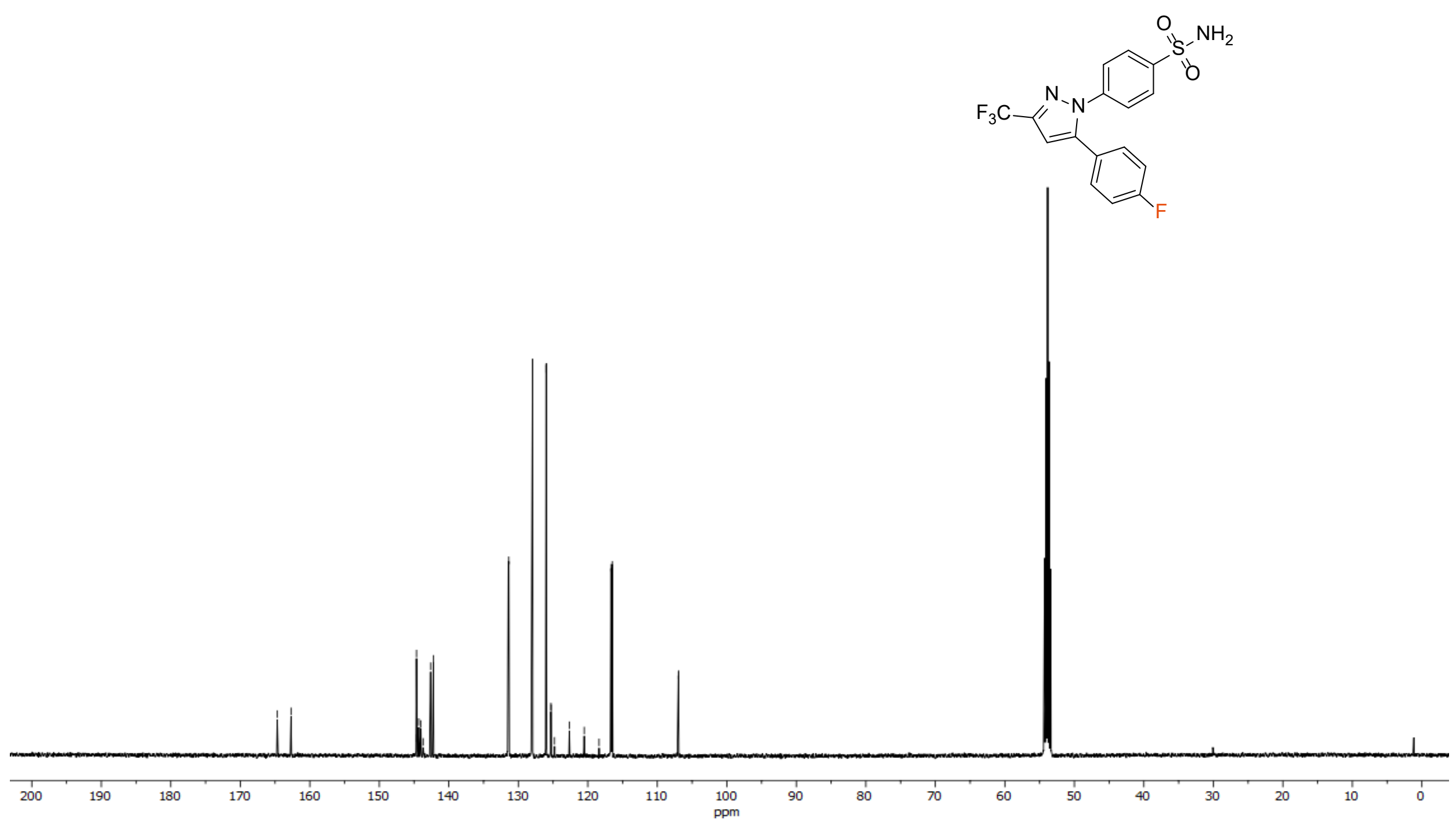


${ }^{19} \mathrm{~F}$ NMR of mavacoxib (2)

$\mathrm{CD}_{2} \mathrm{Cl}_{2}, 298 \mathrm{~K}$

กิ่

$\checkmark$

苯芦芦

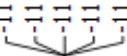

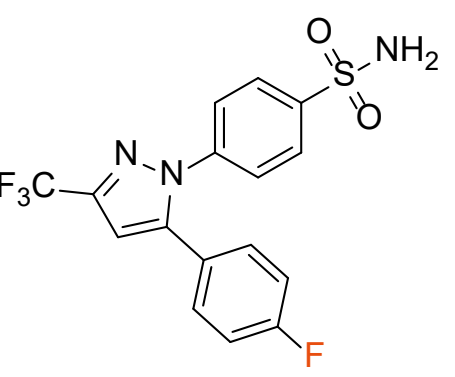

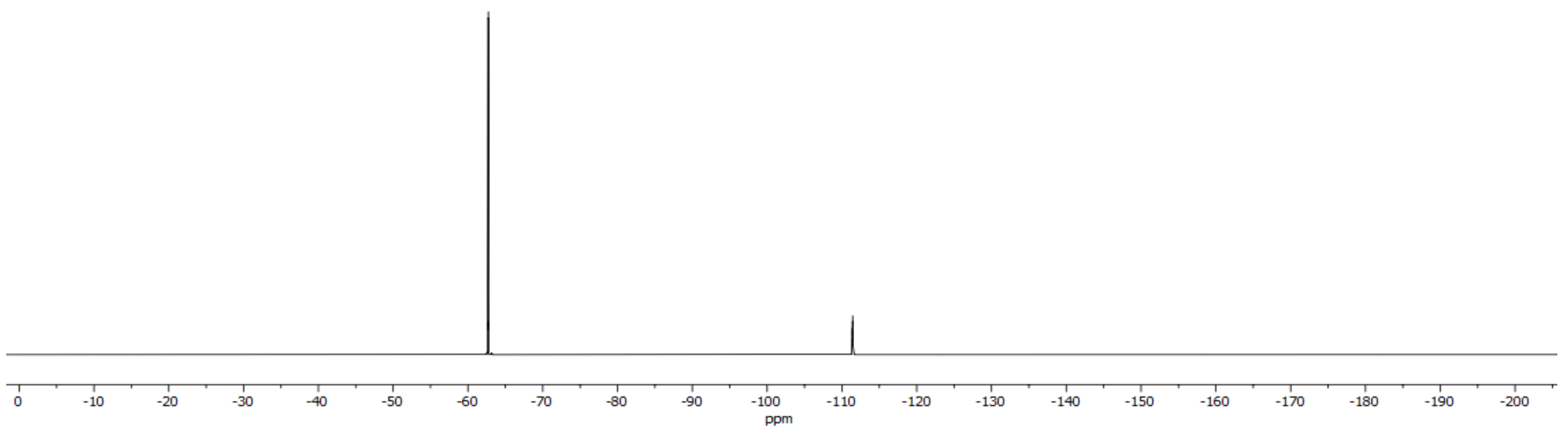


${ }^{1} \mathrm{H}$ NMR of 4-fluorophenyl 4-fluorobenzoate (4b)

$\mathrm{CDCl}_{3}, 298 \mathrm{~K}$

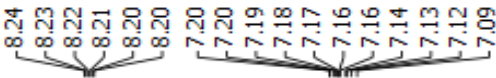
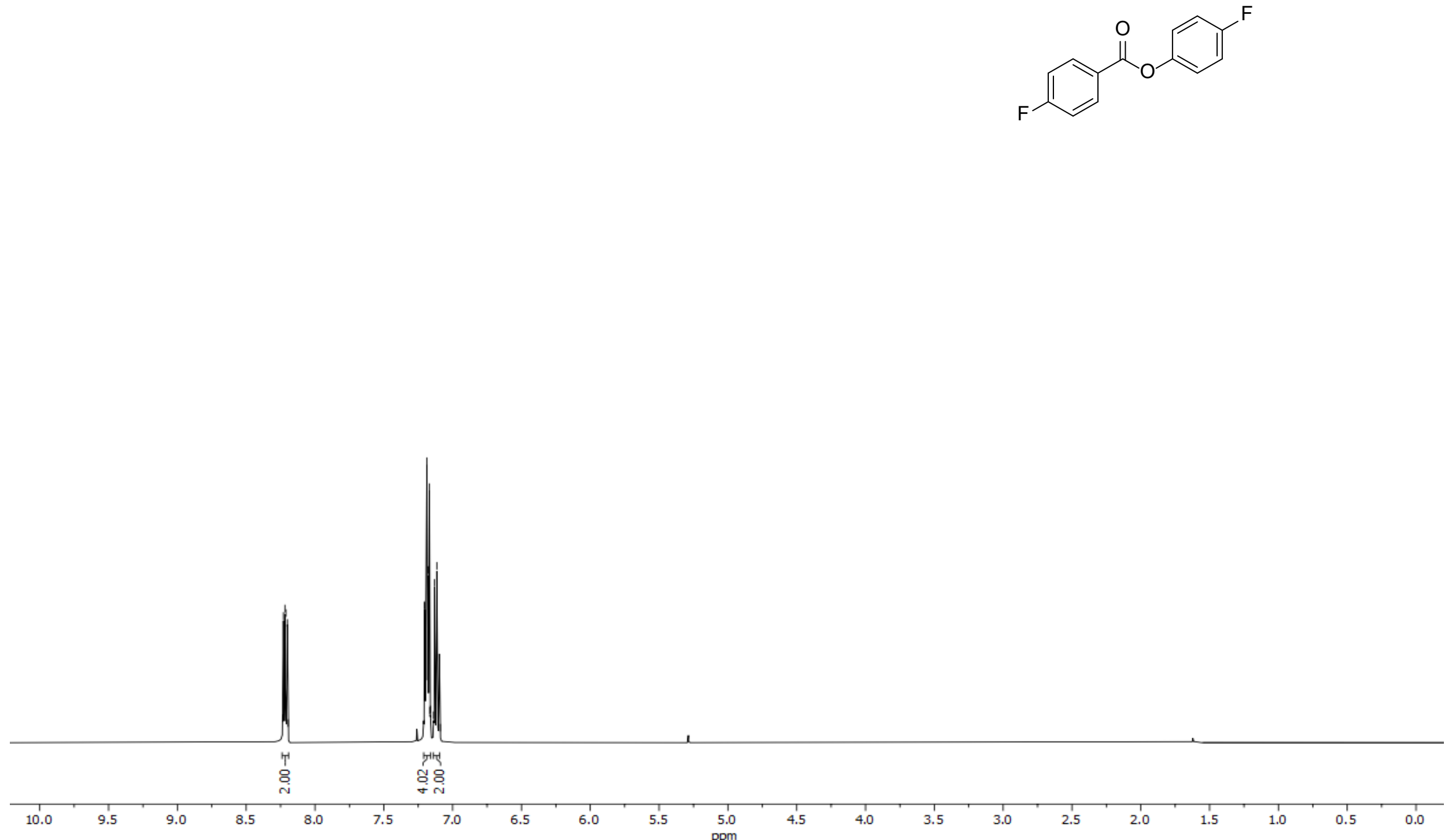
${ }^{13} \mathrm{C}$ NMR of 4-fluorophenyl 4-fluorobenzoate (4b)

$\mathrm{CDCl}_{3}, 298 \mathrm{~K}$

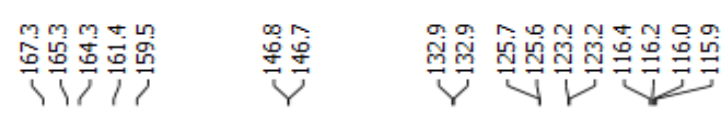
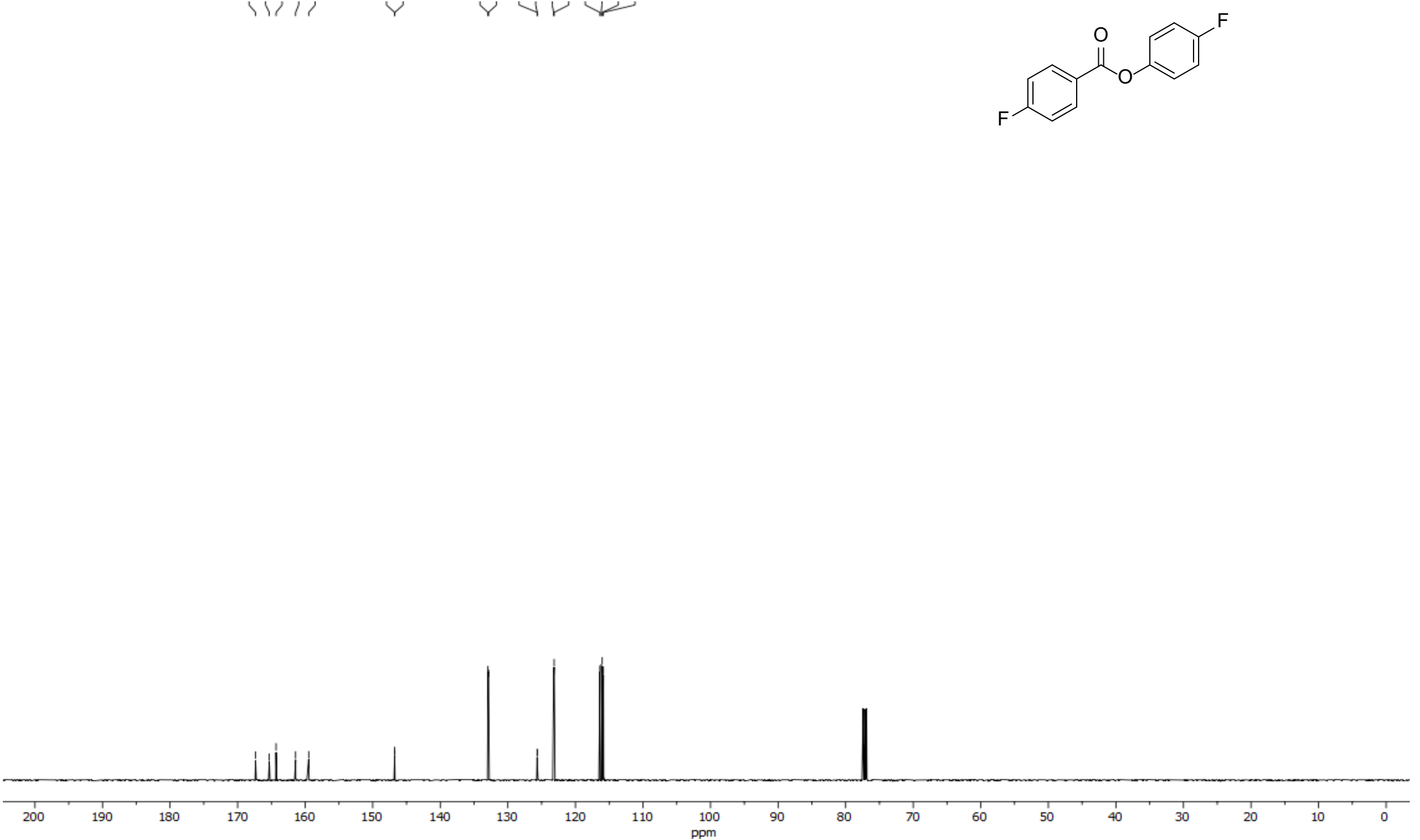
${ }^{19} \mathrm{~F}$ NMR of 4-fluorophenyl 4-fluorobenzoate (4b)

$\mathrm{CDCl}_{3}, 298 \mathrm{~K}$

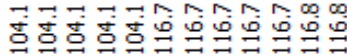
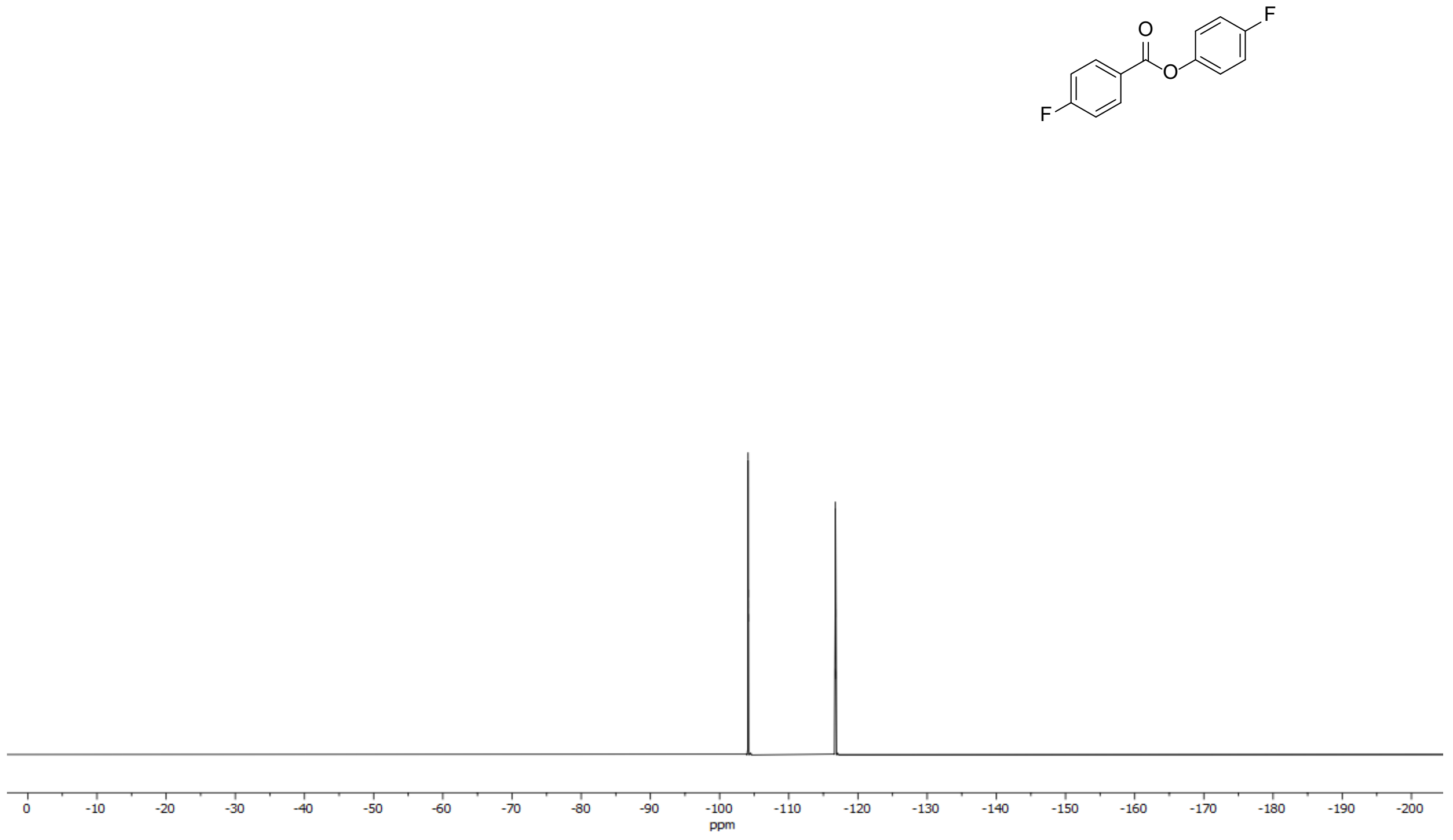


\section{${ }^{1} \mathrm{H}$ NMR of 2-fluoroquinoline (6)}

$\mathrm{CDCl}_{3}, 298 \mathrm{~K}$

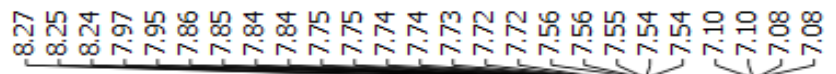
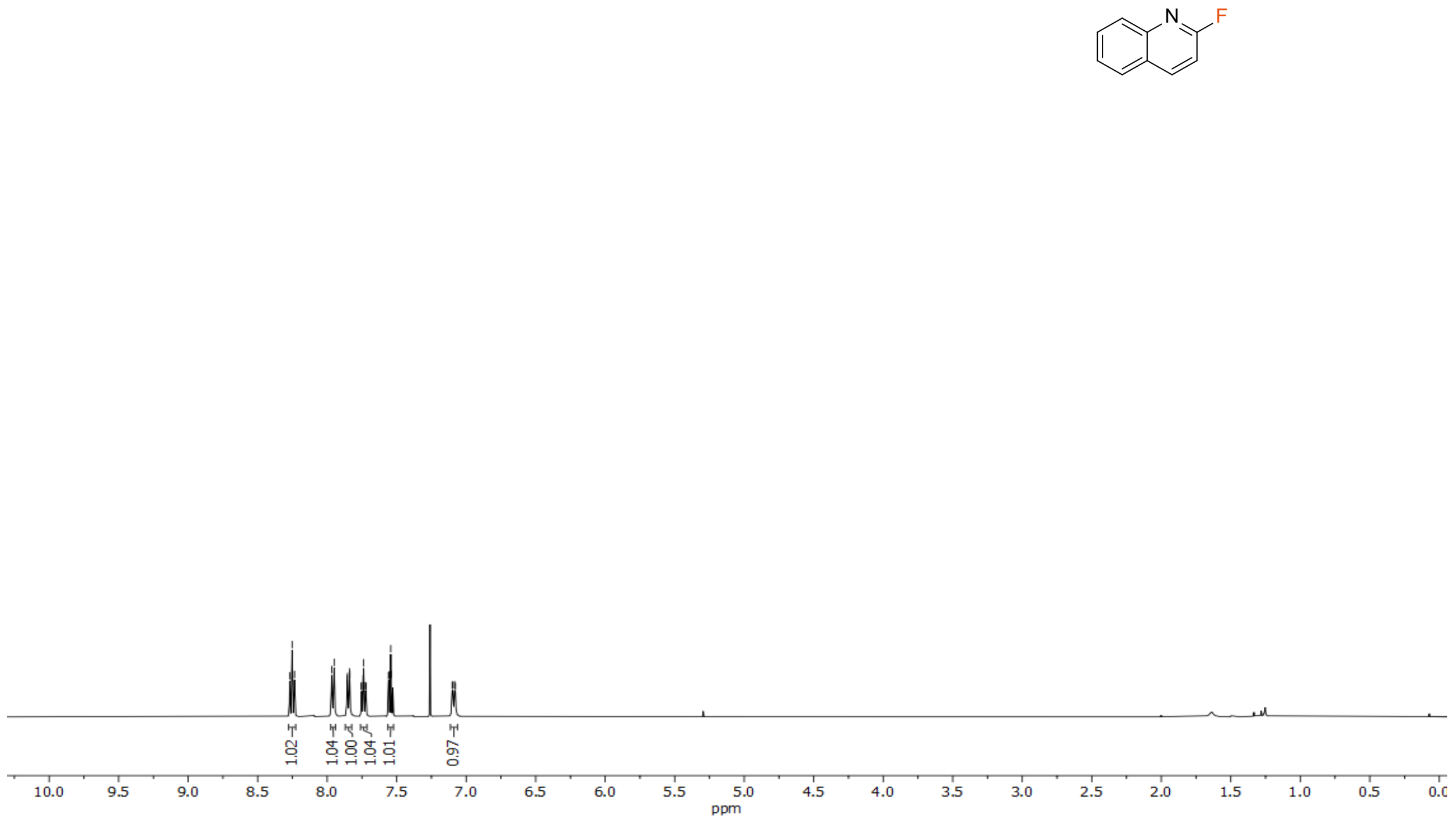
SUPPORTING INFORMATION

S64

${ }^{13} \mathrm{C}$ NMR of 2-fluoroquinoline (6)

$\mathrm{CDCl}_{3}, 298 \mathrm{~K}$

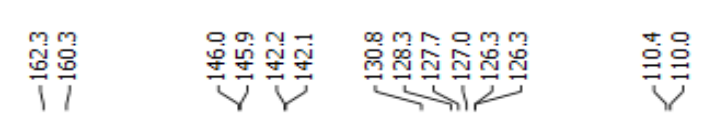

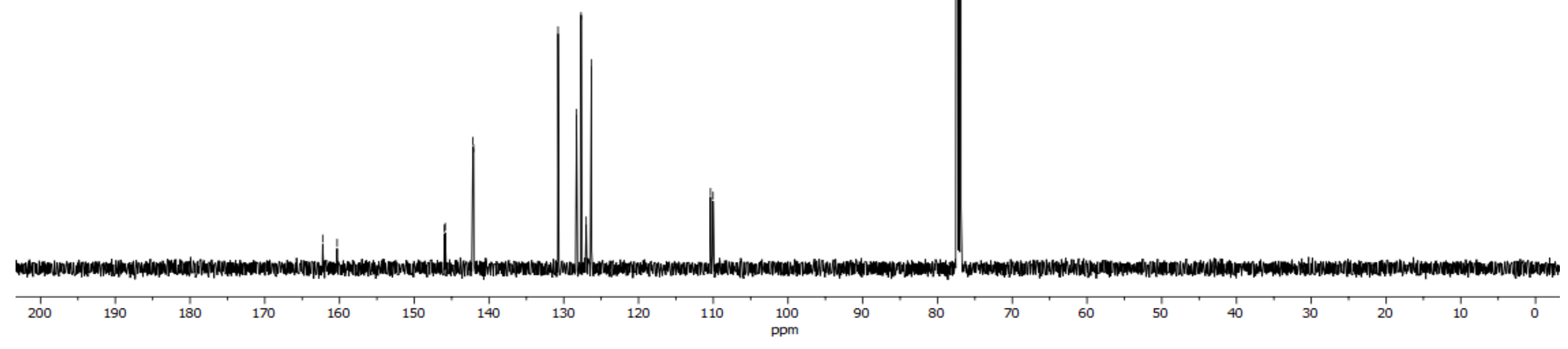


${ }^{19} \mathrm{~F}$ NMR of 2-fluoroquinoline (6)

$\mathrm{CDCl}_{3}, 298 \mathrm{~K}$
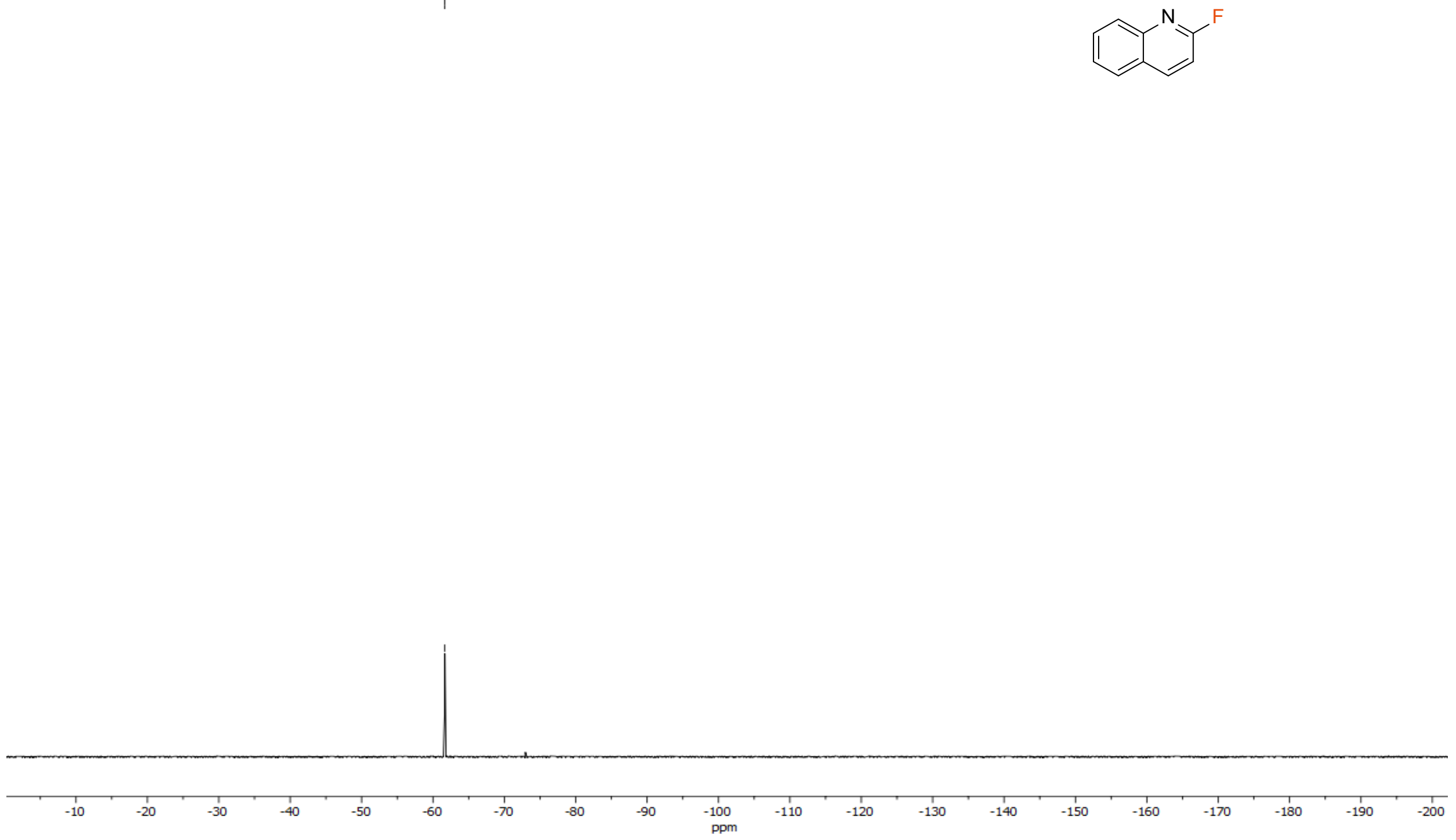
SUPPORTING INFORMATION

S66

${ }^{1} \mathrm{H}$ NMR of 4-fluorobenzophenone (7)

$\mathrm{CDCl}_{3}, 298 \mathrm{~K}$

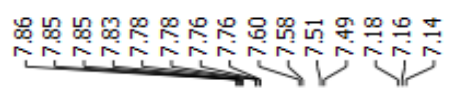<smiles>O=C(c1ccccc1)c1ccc(F)cc1</smiles>

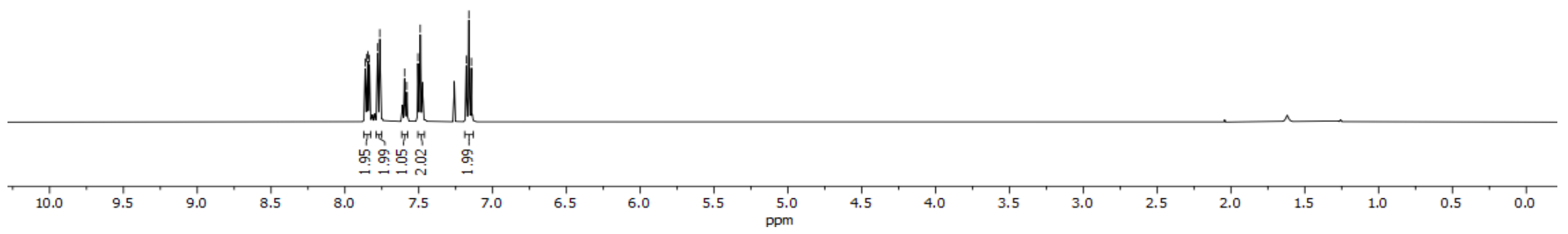


${ }^{13} \mathrm{C}$ NMR of 4-fluorobenzophenone (7)

$\mathrm{CDCl}_{3}, 298 \mathrm{~K}$

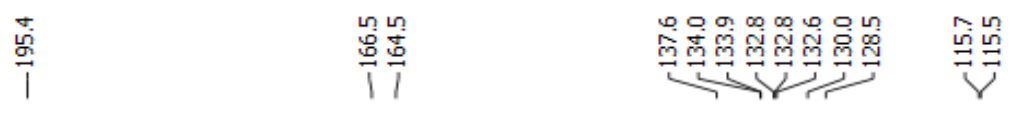
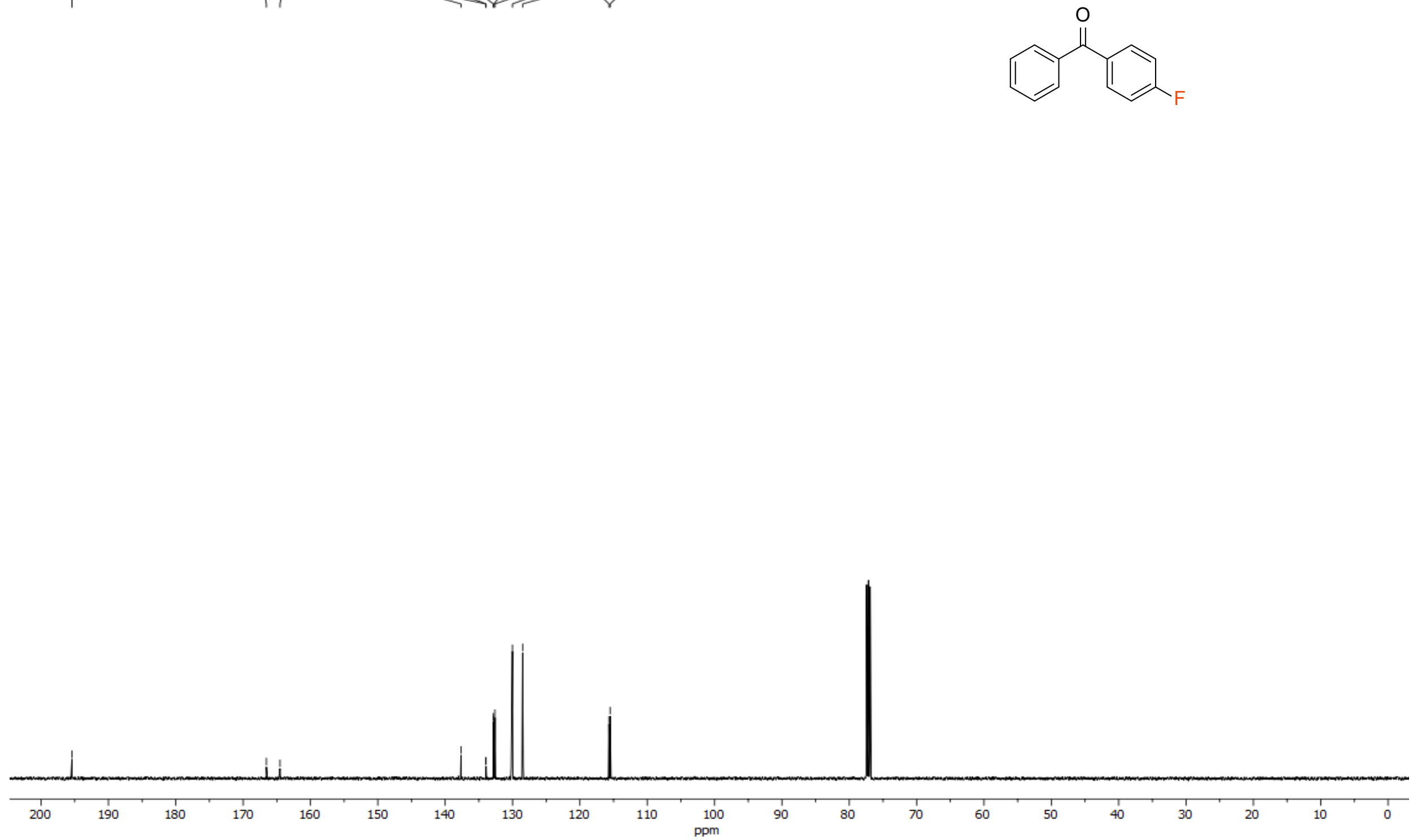
${ }^{19} \mathrm{~F}$ NMR of 4-fluorobenzophenone (7)

$\mathrm{CDCl}_{3}, 298 \mathrm{~K}$

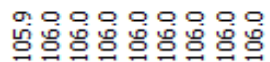

thy
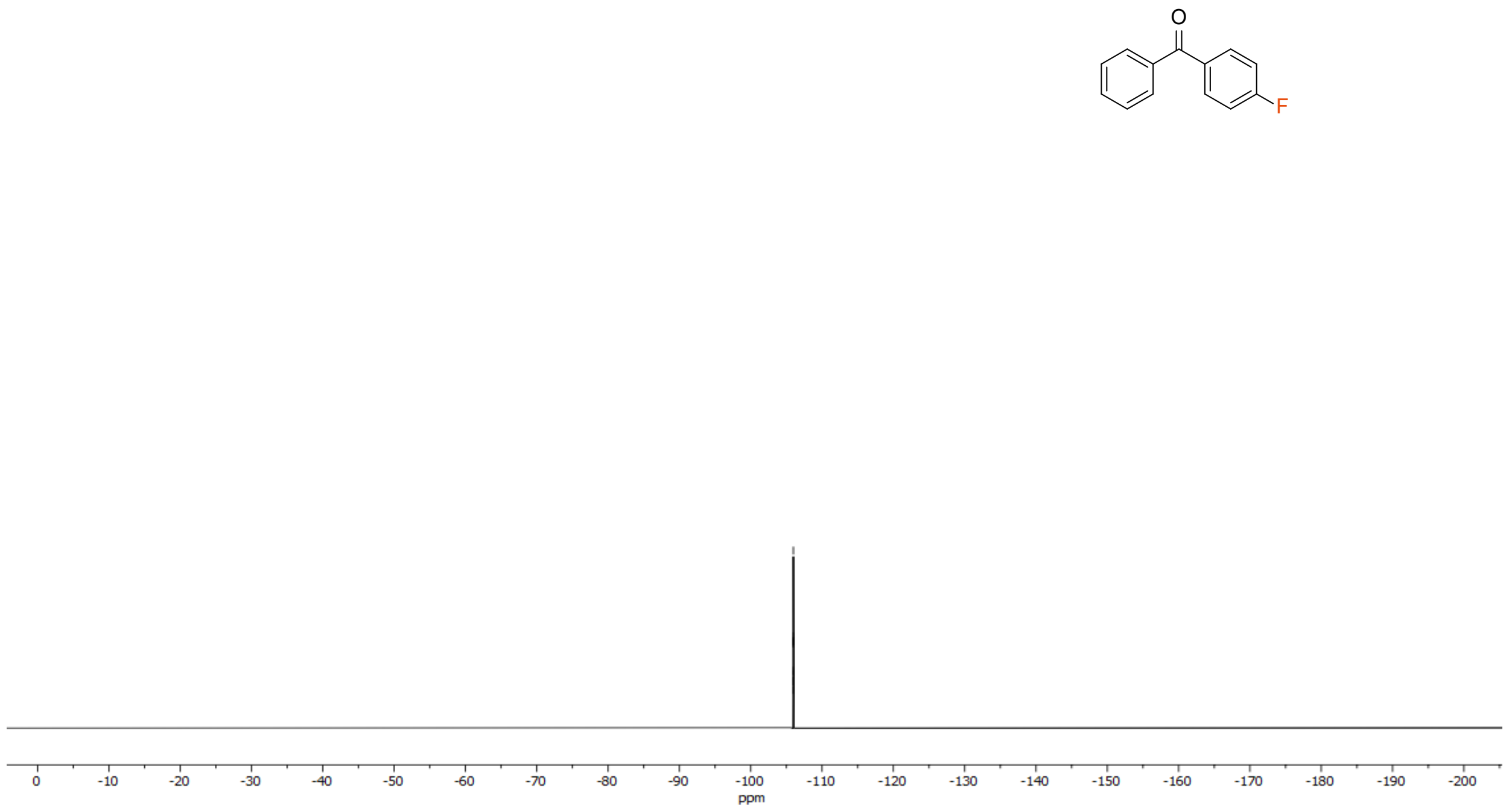


\section{${ }^{1} \mathrm{H}$ NMR of D-glucose derivative 8}

$\mathrm{CDCl}_{3}, 298 \mathrm{~K}$
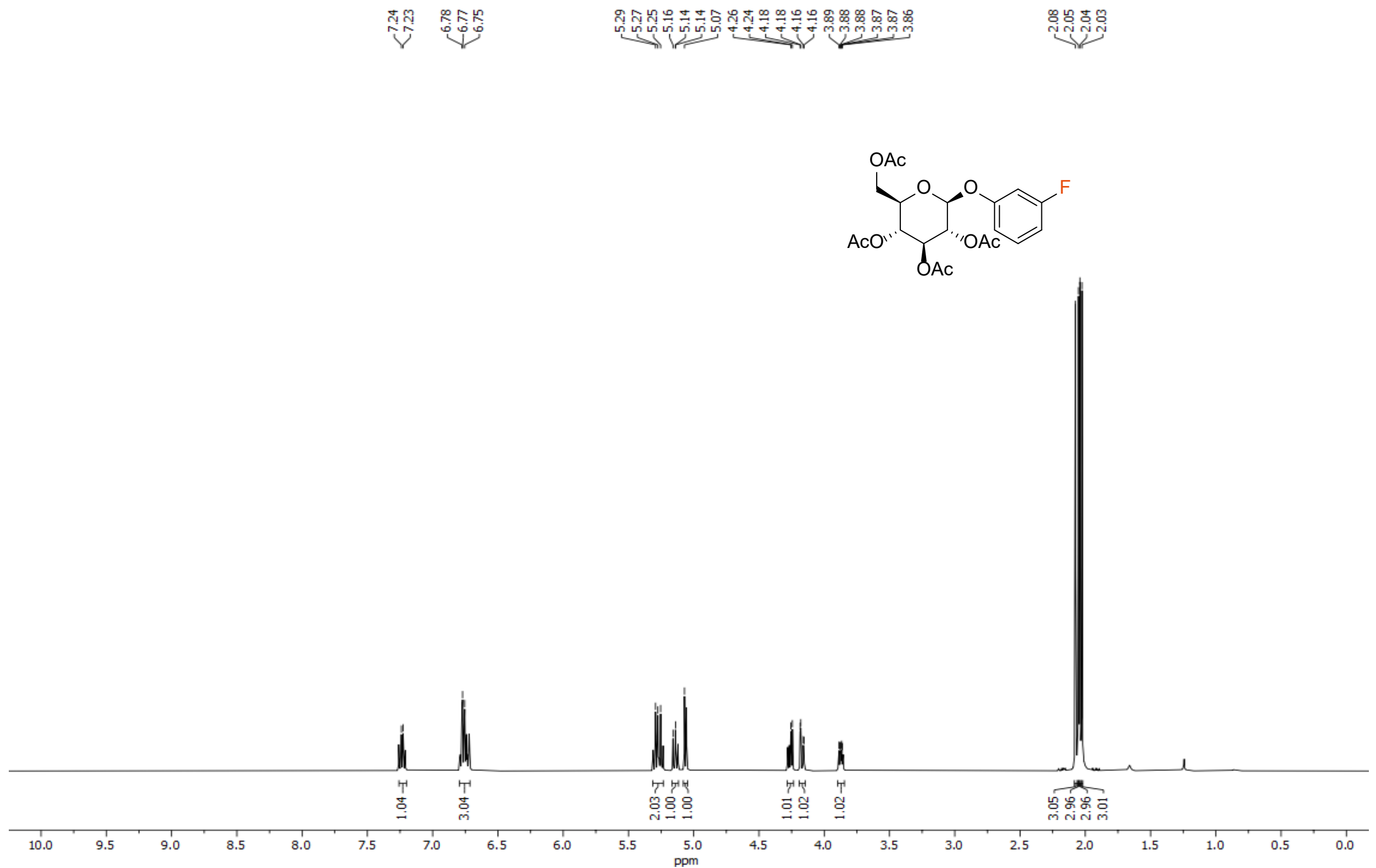


\section{${ }^{13} \mathrm{C}$ NMR of D-glucose derivative 8}

$\mathrm{CDCl}_{3}, 298 \mathrm{~K}$

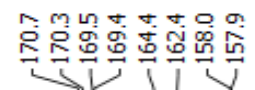
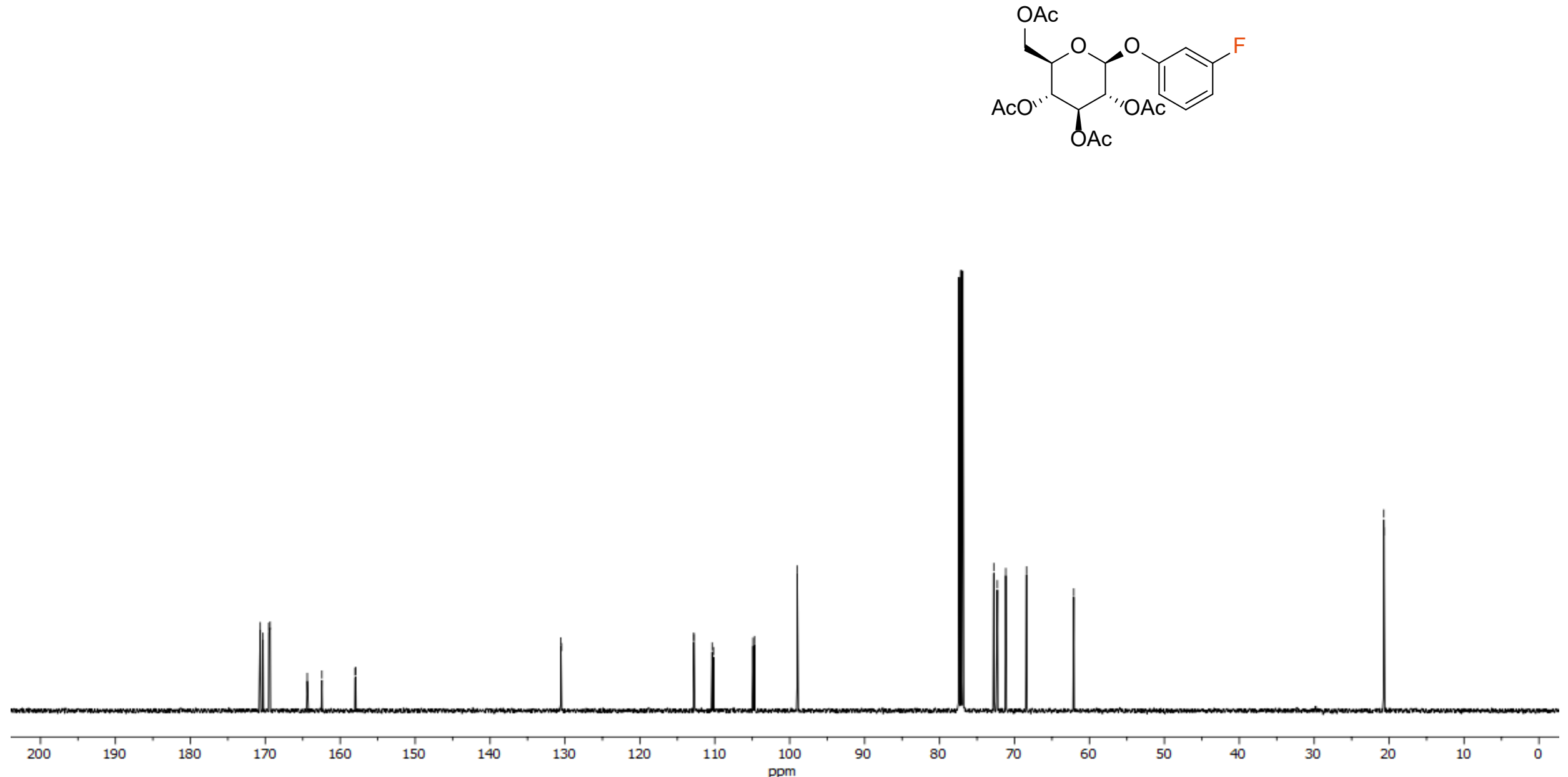
${ }^{19} \mathrm{~F}$ NMR of D-glucose derivative 8

$\mathrm{CDCl}_{3}, 298 \mathrm{~K}$
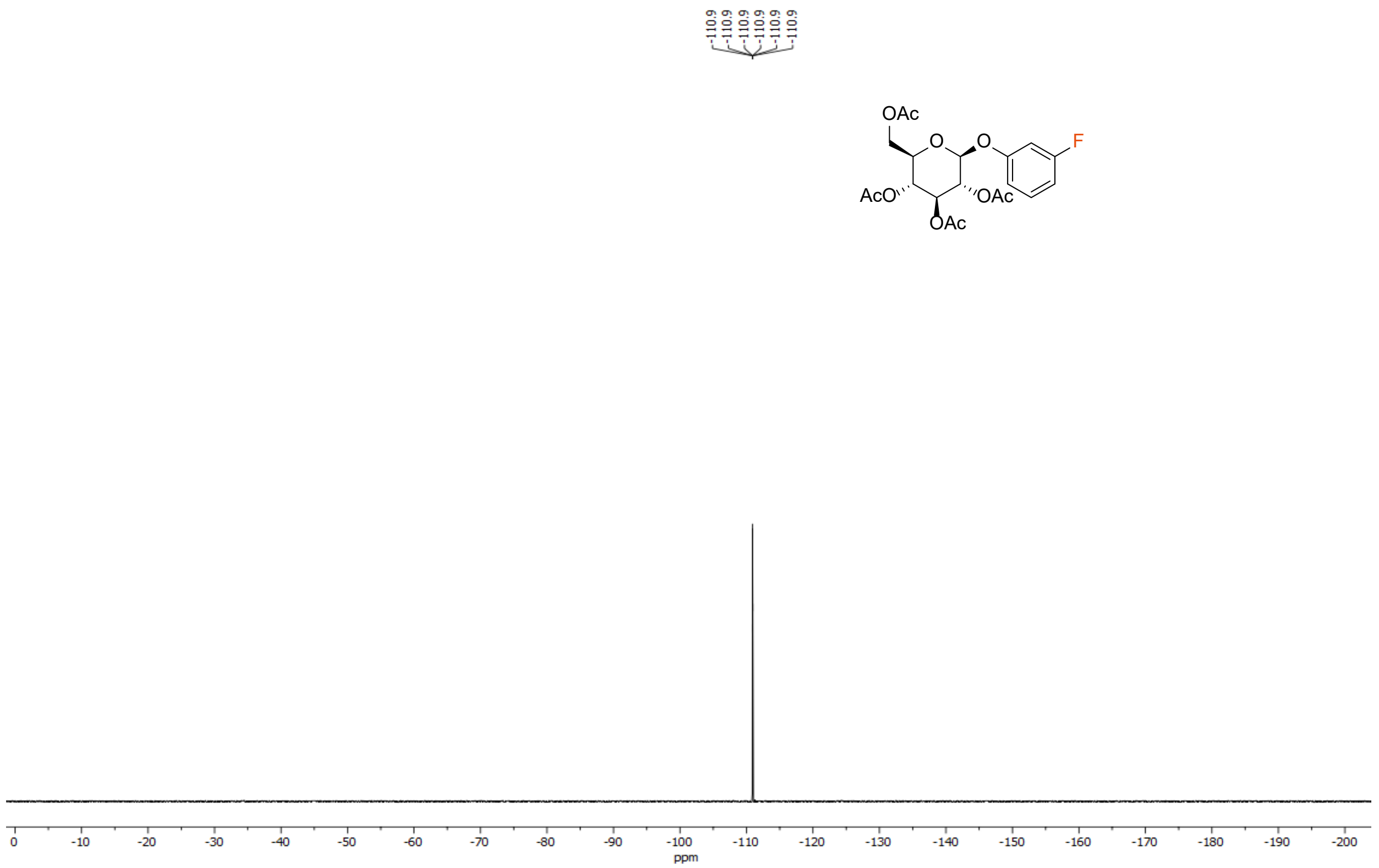
${ }^{1} \mathrm{H}$ NMR of 6-fluoro-2-naphthonitrile (12)

$\mathrm{CDCl}_{3}, 298 \mathrm{~K}$

\section{管}
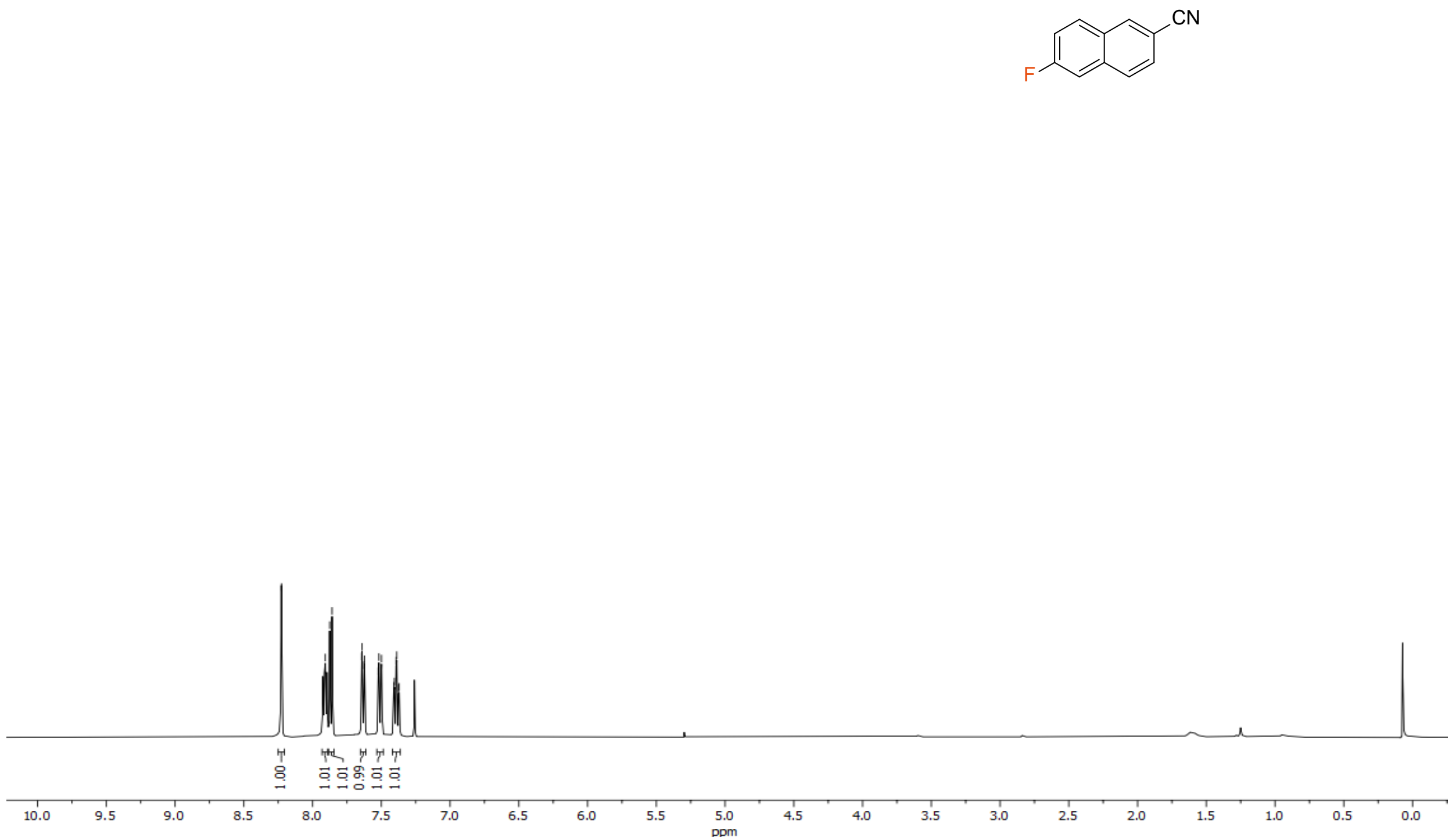
${ }^{13} \mathrm{C}$ NMR of 6-fluoro-2-naphthonitrile (12)

$\mathrm{CDCl}_{3}, 298 \mathrm{~K}$
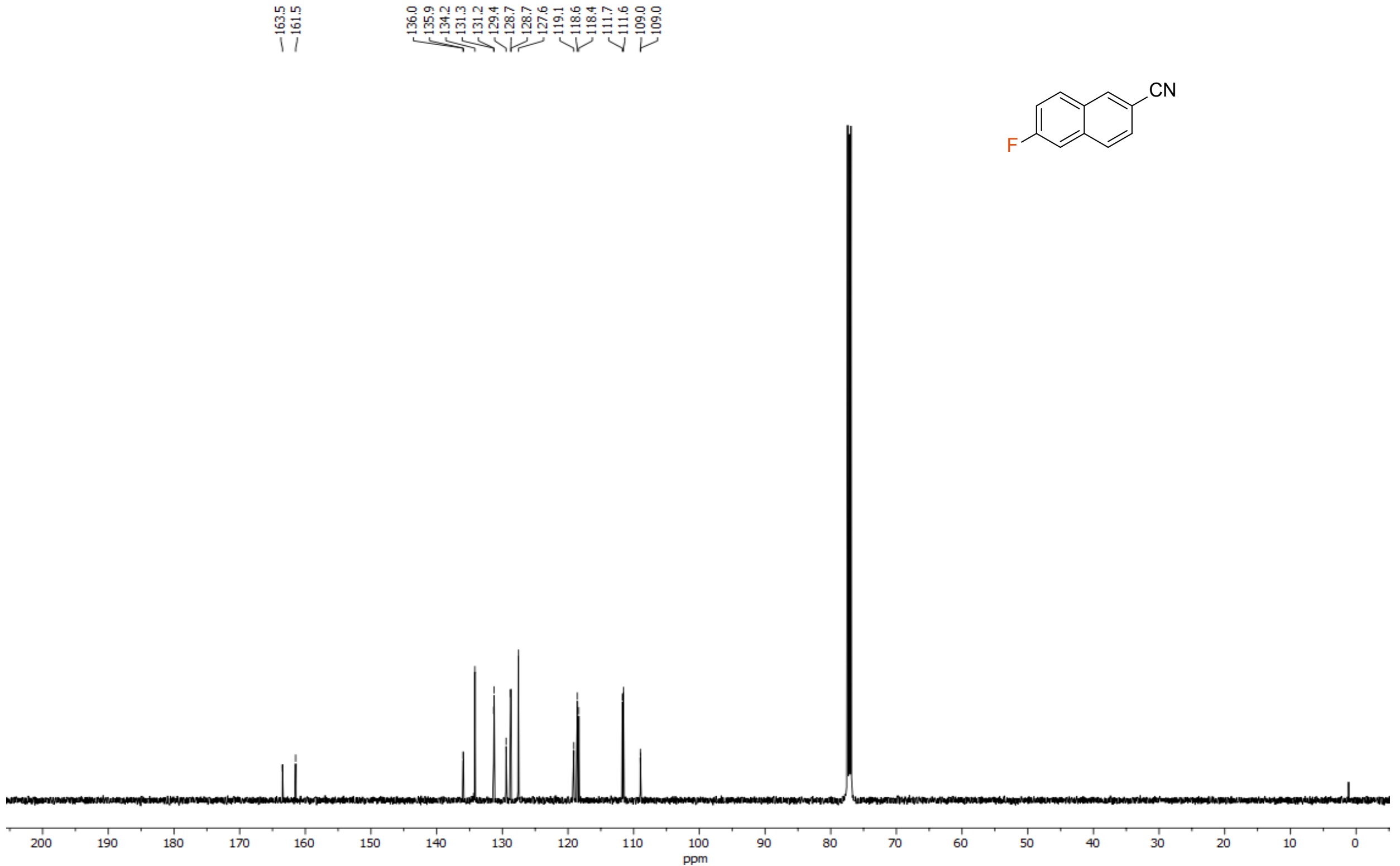
${ }^{19} \mathrm{~F}$ NMR of 6-fluoro-2-naphthonitrile (12)

$\mathrm{CDCl}_{3}, 298 \mathrm{~K}$
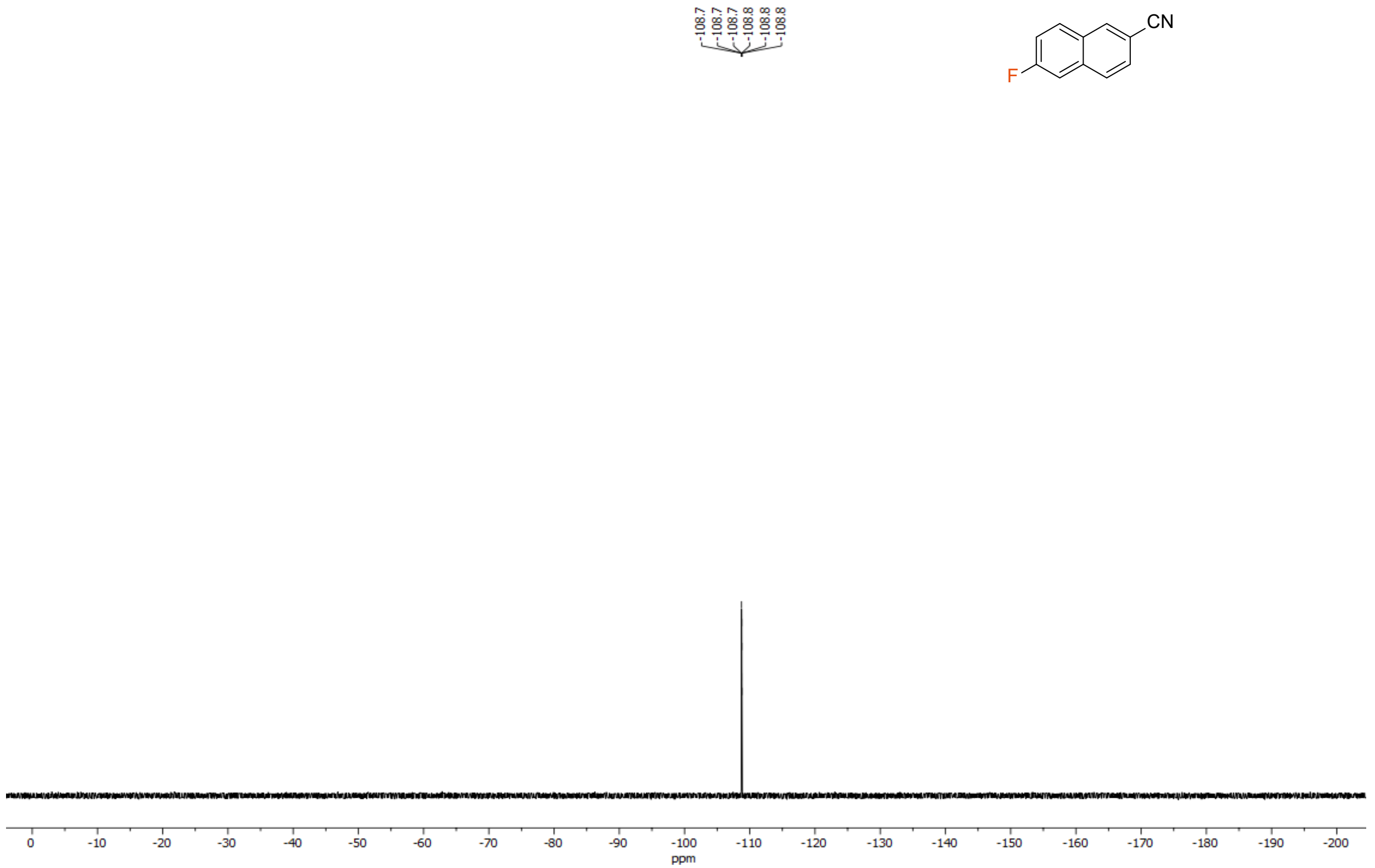
${ }^{1} \mathrm{H}$ NMR of 5-(2-fluorophenyl)-3-(3-fluorophenyl)-1,2,4-oxadiazole (13)

$\mathrm{CDCl}_{3}, 298 \mathrm{~K}$

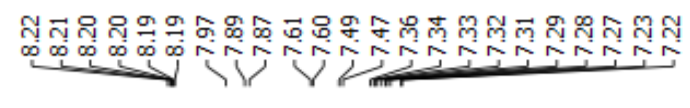
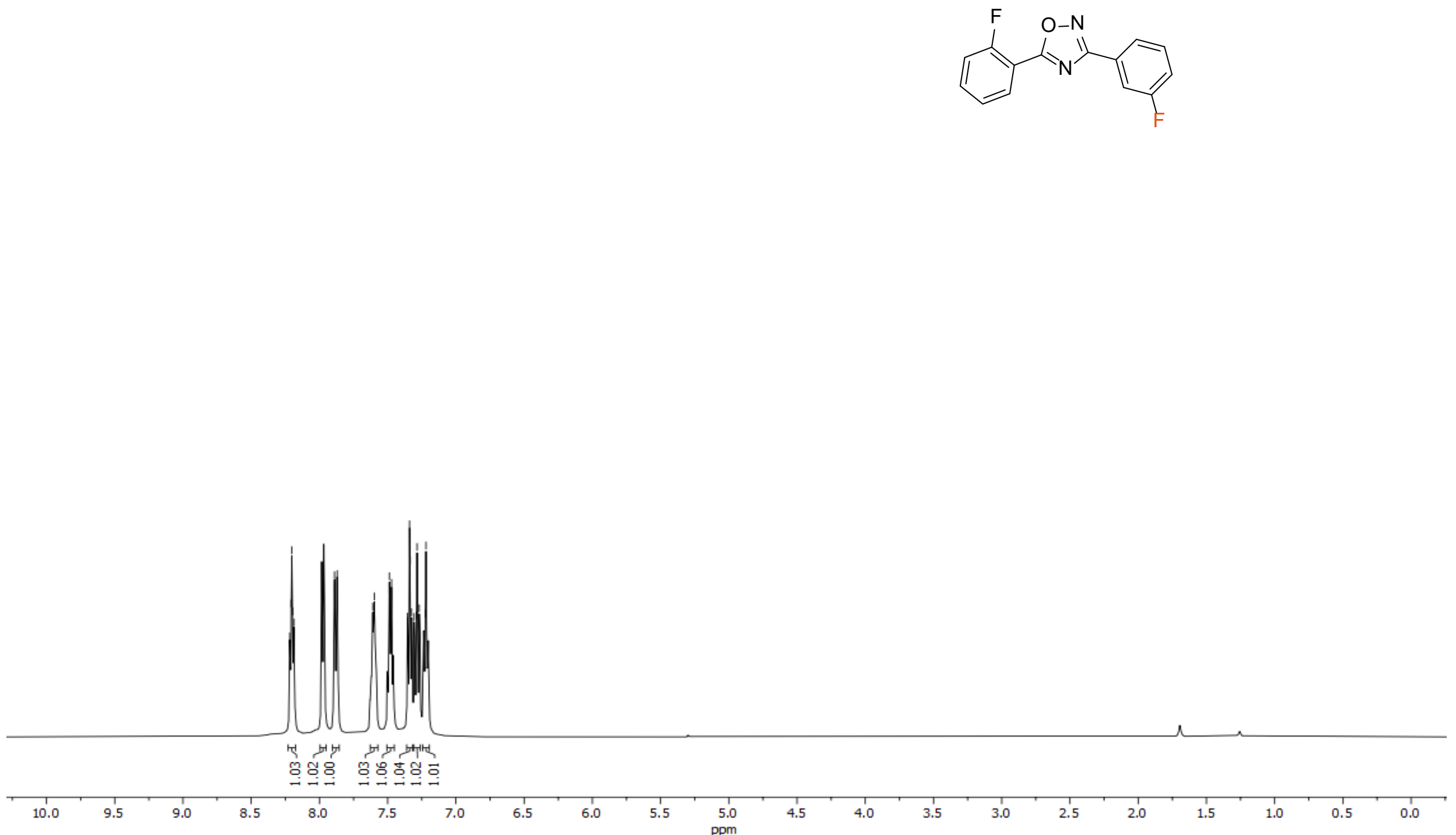
${ }^{13} \mathrm{C}$ NMR of 5-(2-fluorophenyl)-3-(3-fluorophenyl)-1,2,4-oxadiazole (13)

$\mathrm{CDCl}_{3}, 298 \mathrm{~K}$
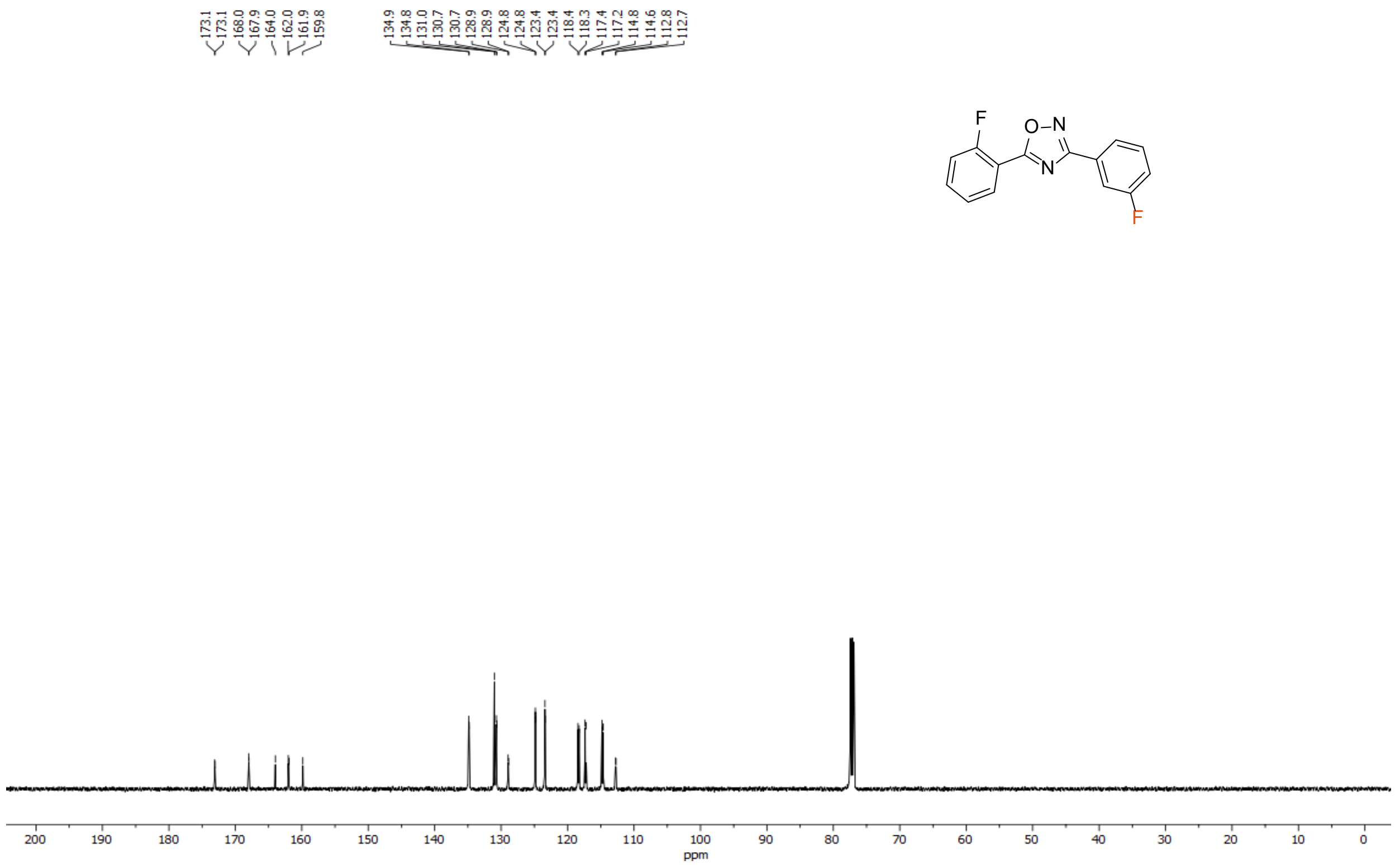
${ }^{19} \mathrm{~F}$ NMR of 5-(2-fluorophenyl)-3-(3-fluorophenyl)-1,2,4-oxadiazole (13)

$\mathrm{CDCl}_{3}, 298 \mathrm{~K}$

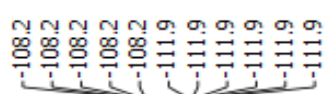

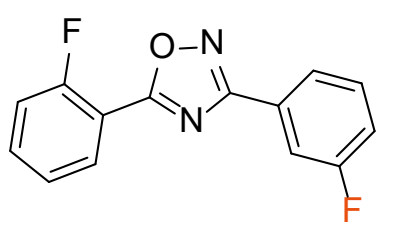

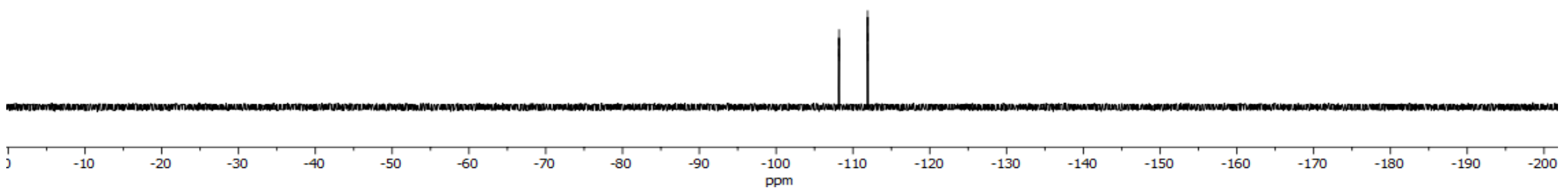


${ }^{1} \mathrm{H}$ NMR of 4-fluorophenyl methyl sulfone (14)

$\mathrm{CDCl}_{3}, 298 \mathrm{~K}$

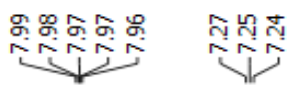

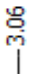
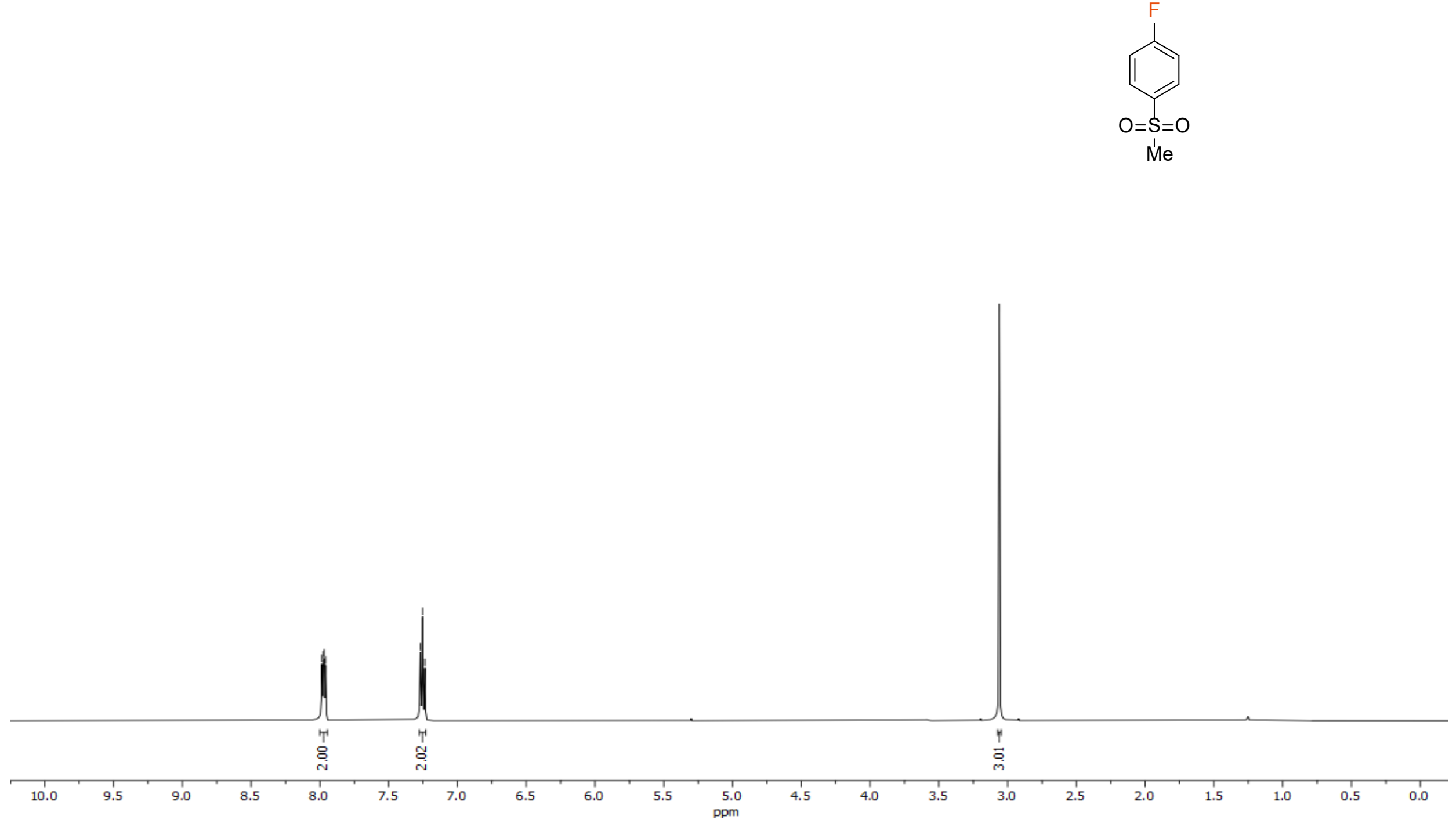
${ }^{13} \mathrm{C}$ NMR of 4-fluorophenyl methyl sulfone (14)

$\mathrm{CDCl}_{3}, 298 \mathrm{~K}$

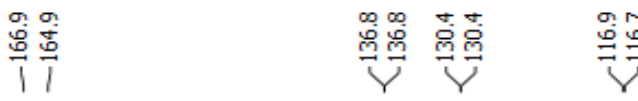

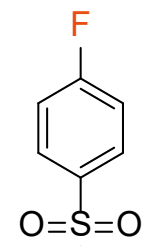

Me

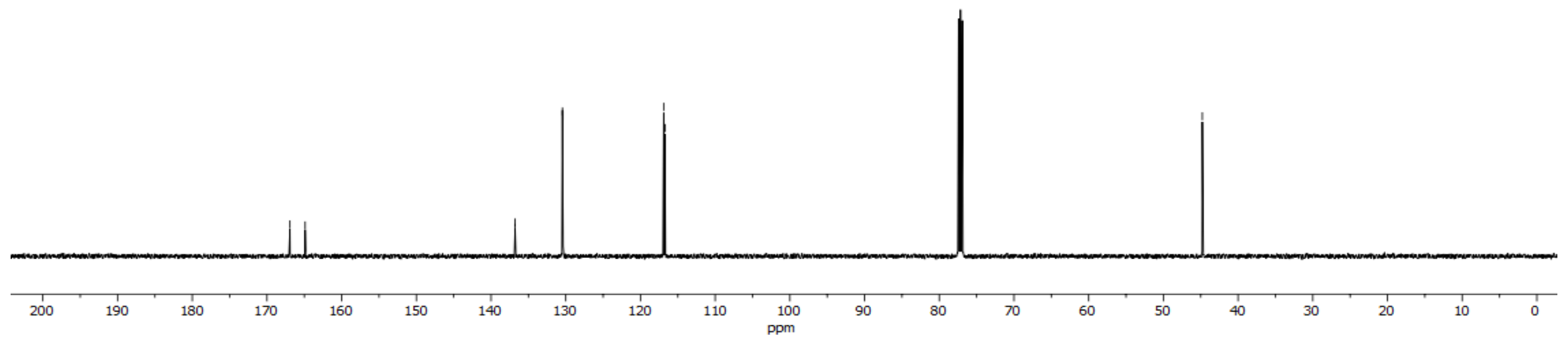


${ }^{19} \mathrm{~F}$ NMR of 4-fluorophenyl methyl sulfone (14)

$\mathrm{CDCl}_{3}, 298 \mathrm{~K}$

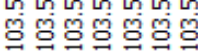 \\ in}

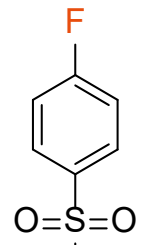

Me

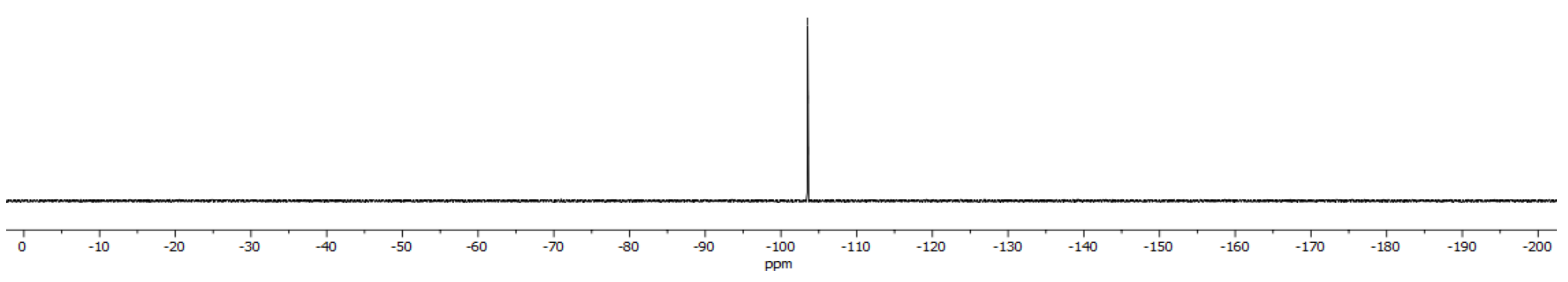


${ }^{1} \mathrm{H}$ NMR of 6-fluoro-1-tetralone (16)

$\mathrm{CDCl}_{3}, 298 \mathrm{~K}$

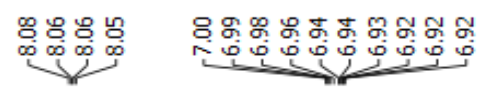

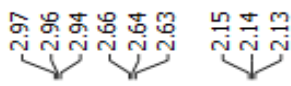
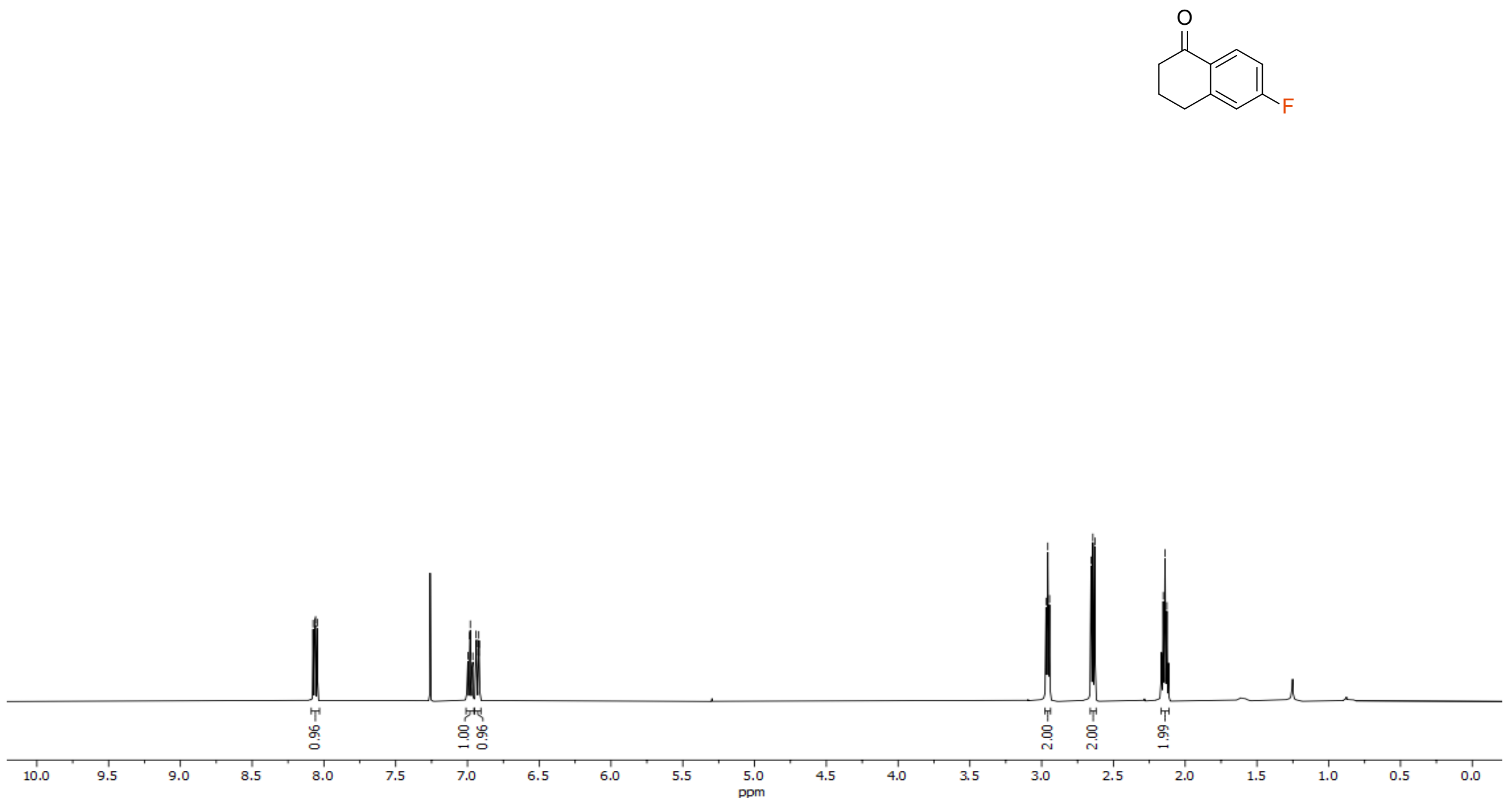
${ }^{19} \mathrm{~F}$ NMR of 6-fluoro-1-tetralone (16)

$\mathrm{CDCl}_{3}, 298 \mathrm{~K}$

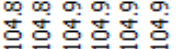
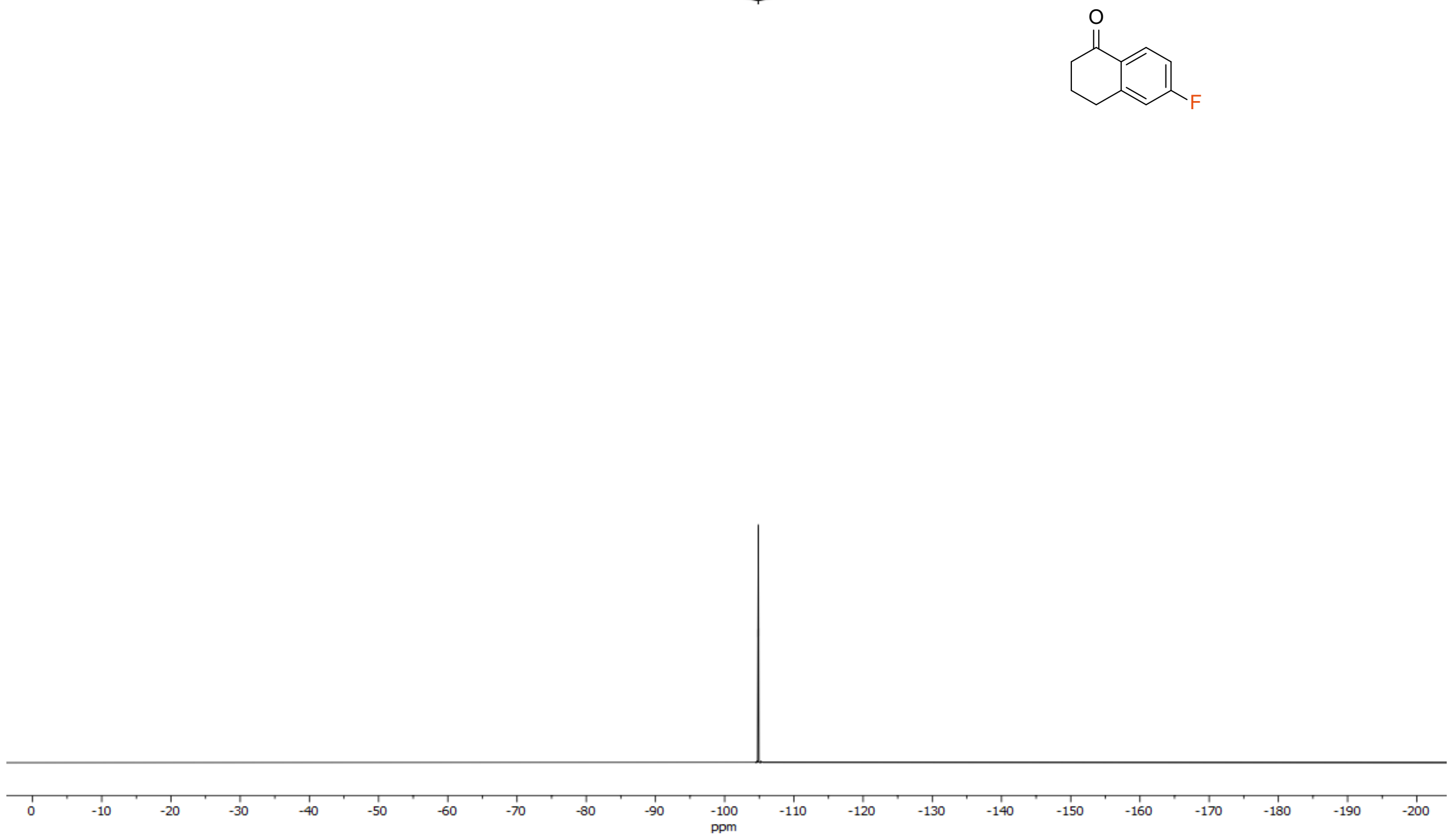
${ }^{1} \mathrm{H}$ NMR of 2,2'-(5-fluoro-1,3-phenylene)bis(2-methylpropanenitrile) (17)

$\mathrm{CDCl}_{3}, 298 \mathrm{~K}$
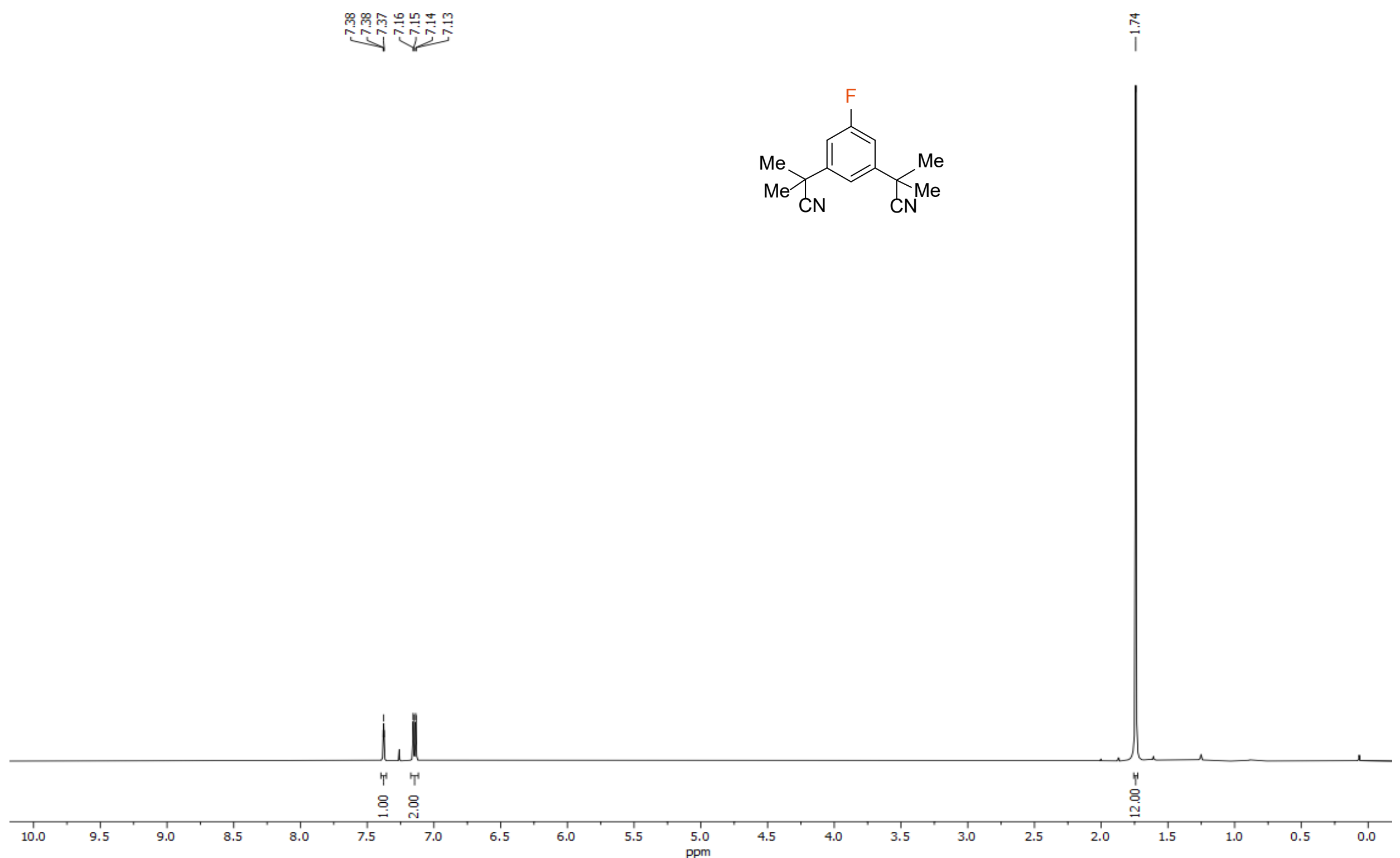
${ }^{13}$ C NMR of 2,2'-(5-fluoro-1,3-phenylene)bis(2-methylpropanenitrile) (17)

$\mathrm{CDCl}_{3}, 298 \mathrm{~K}$

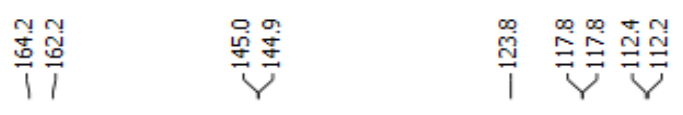
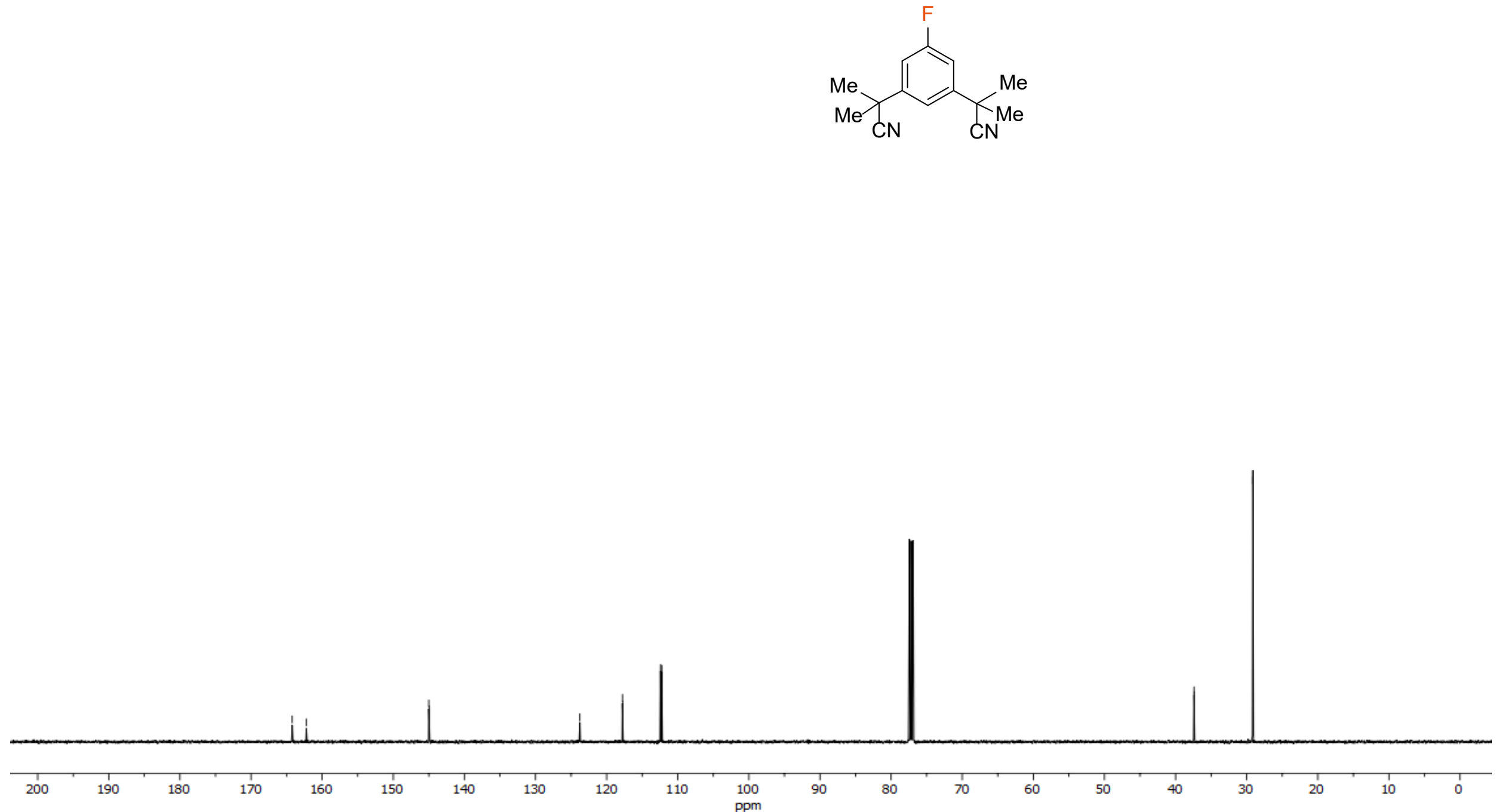
${ }^{19}$ F NMR of 2,2'-(5-fluoro-1,3-phenylene)bis(2-methylpropanenitrile) (17)

$\mathrm{CDCl}_{3}, 298 \mathrm{~K}$
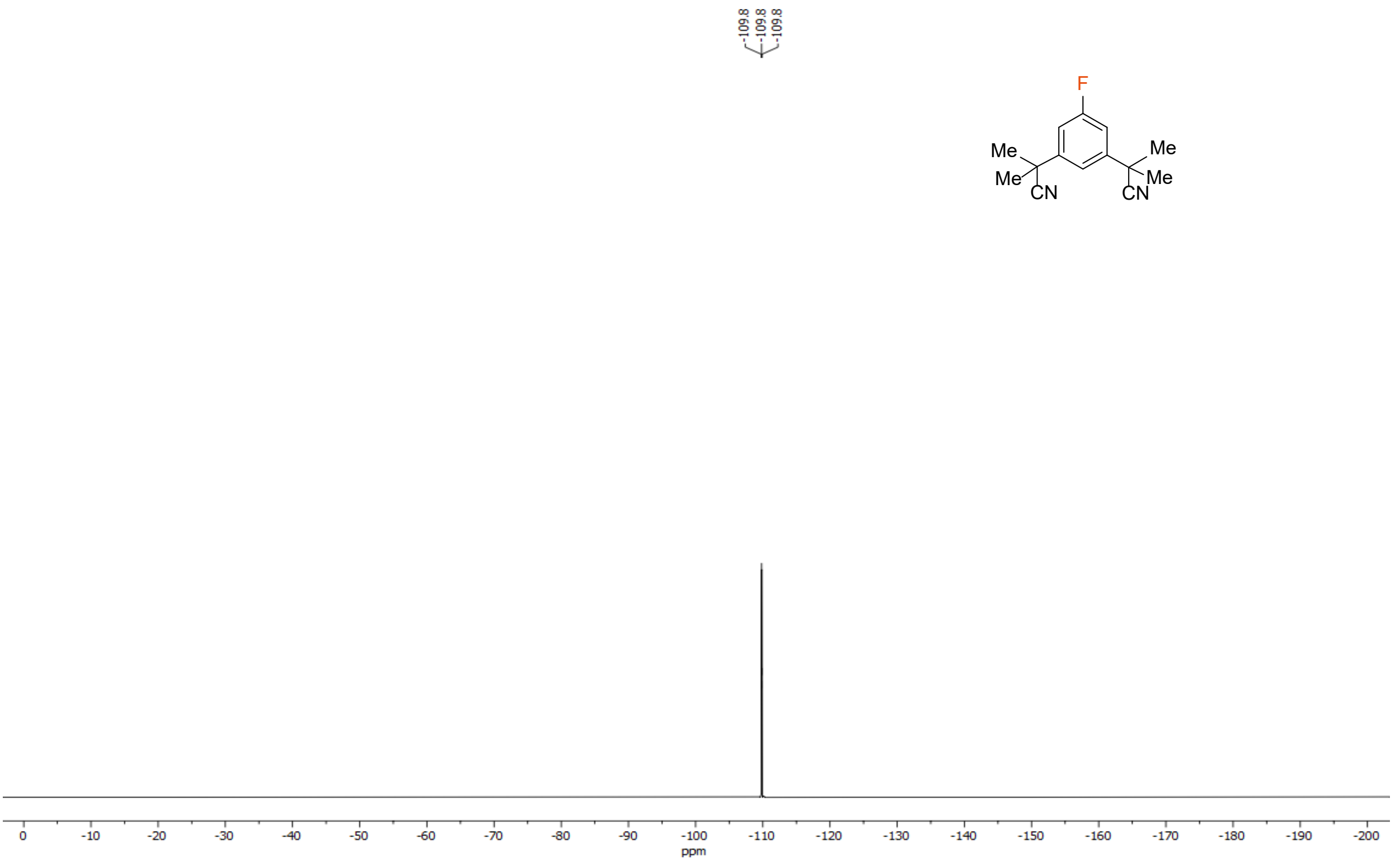
${ }^{1} \mathrm{H}$ NMR of 6-fluorofluorescein diacetate (18)

$\mathrm{CDCl}_{3}, 298 \mathrm{~K}$
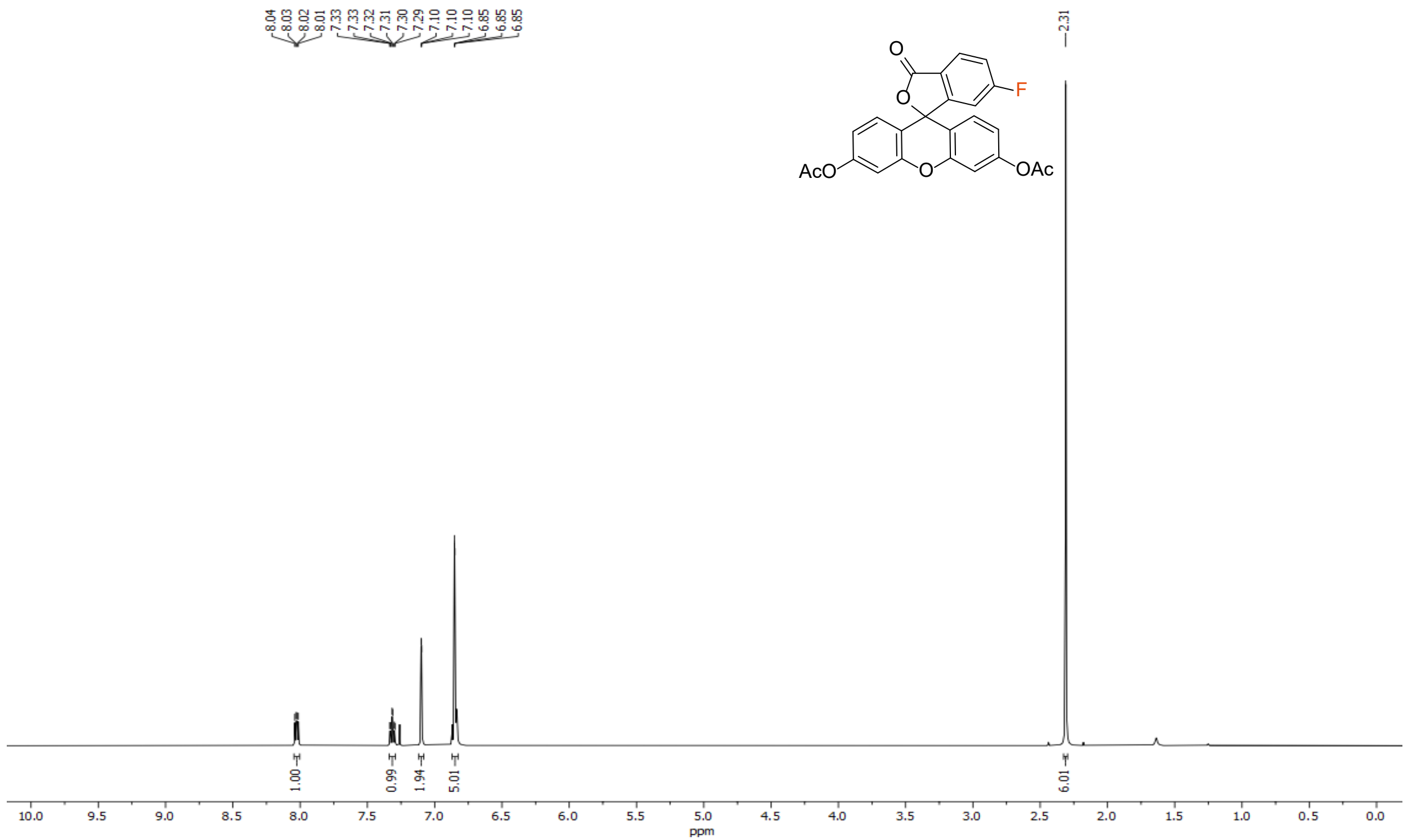
${ }^{13} \mathrm{C}$ NMR of 6 -fluorofluorescein diacetate (18)

$\mathrm{CDCl}_{3}, 298 \mathrm{~K}$

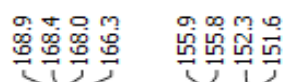

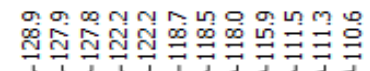

एं

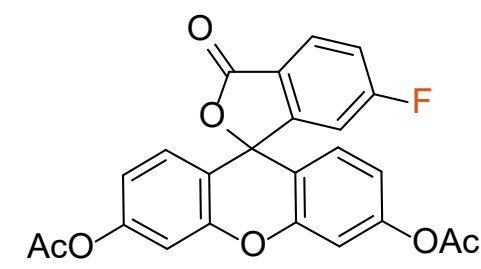

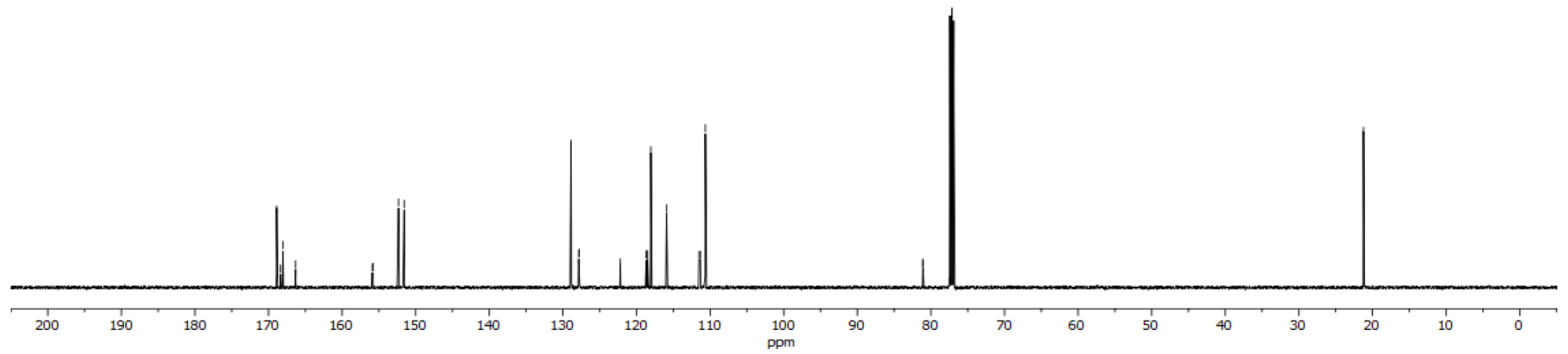


${ }^{19} \mathrm{~F}$ NMR of 6-fluorofluorescein diacetate (18)

$\mathrm{CDCl}_{3}, 298 \mathrm{~K}$

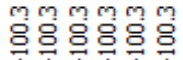
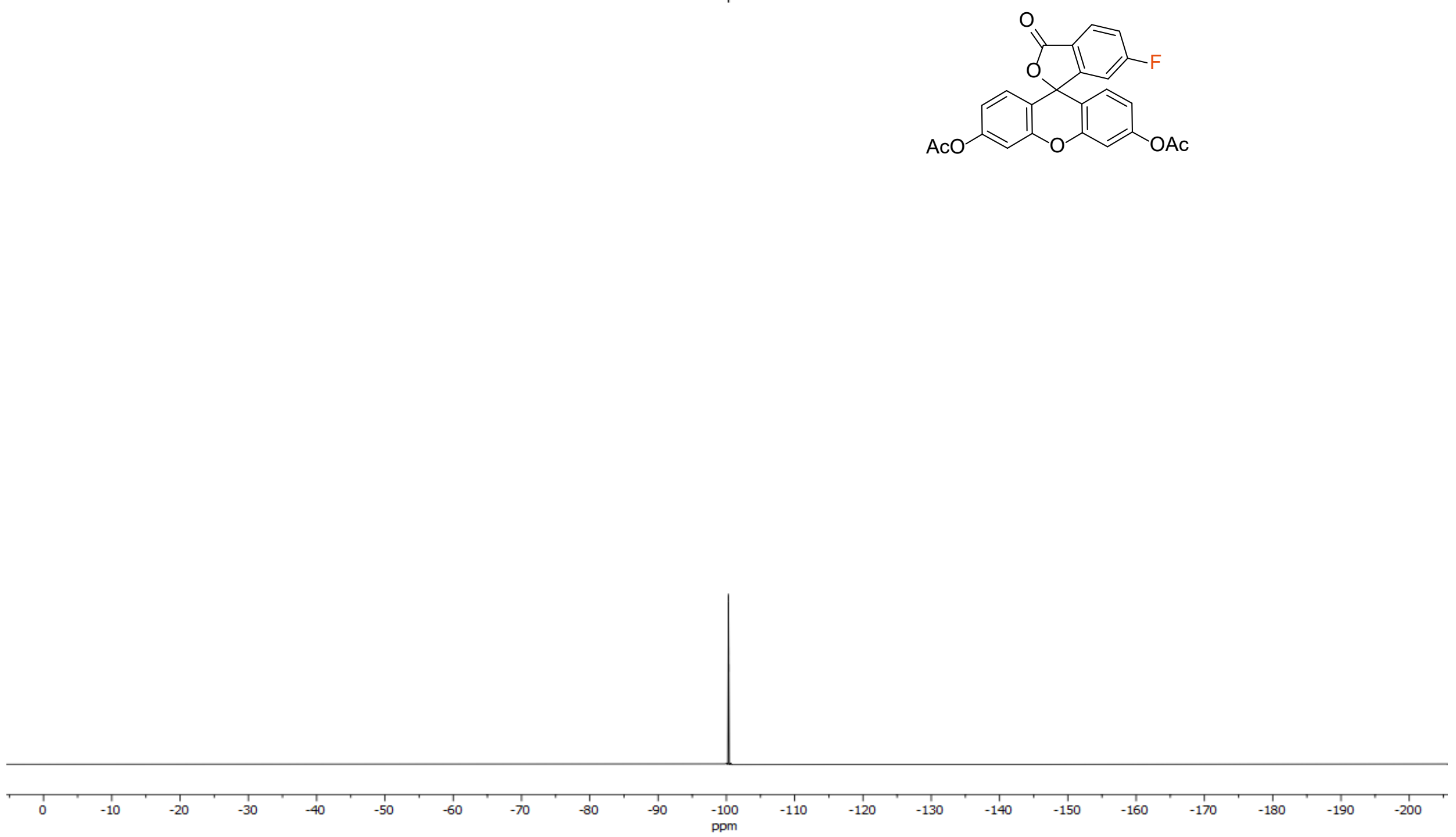
${ }^{1} \mathrm{H}$ NMR of 2-(4-fluorophenyl)pyrimidine (19)

$\mathrm{CDCl}_{3}, 298 \mathrm{~K}$
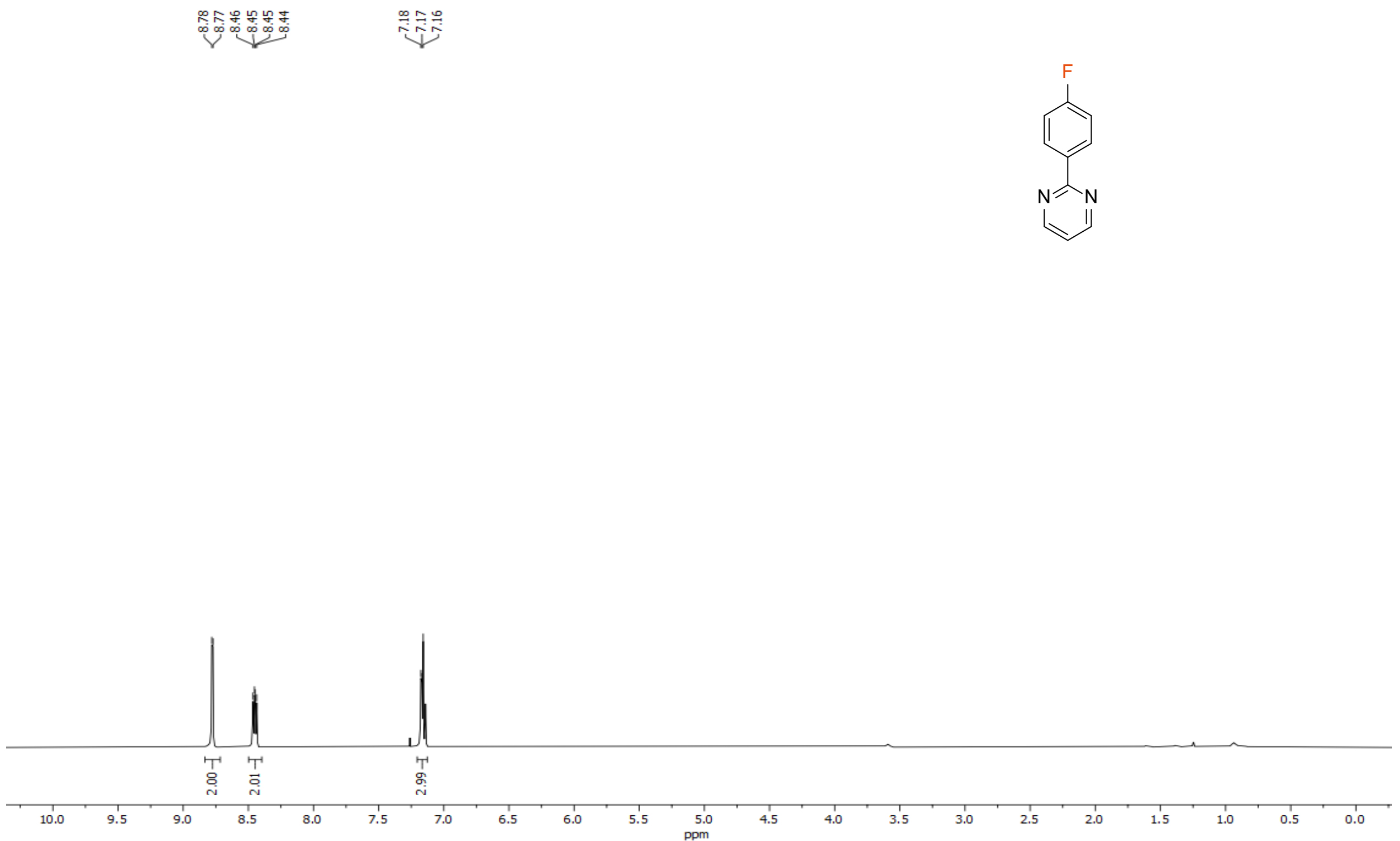
${ }^{13} \mathrm{C}$ NMR of 2-(4-fluorophenyl)pyrimidine (19)

$\mathrm{CDCl}_{3}, 298 \mathrm{~K}$

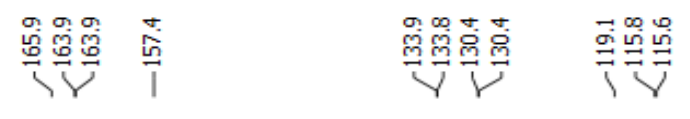

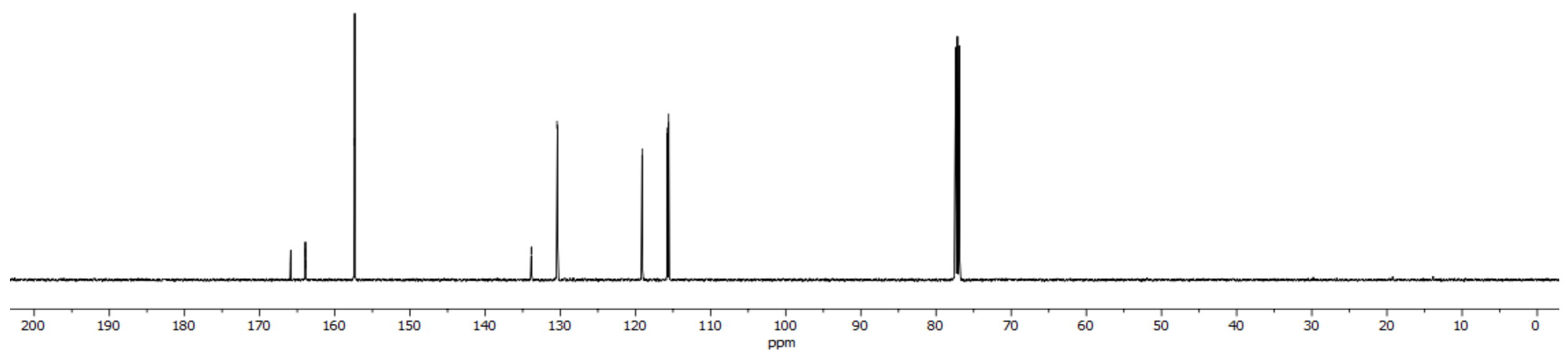


${ }^{19} \mathrm{~F}$ NMR of 2-(4-fluorophenyl)pyrimidine (19)

$\mathrm{CDCl}_{3}, 298 \mathrm{~K}$

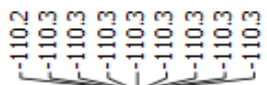
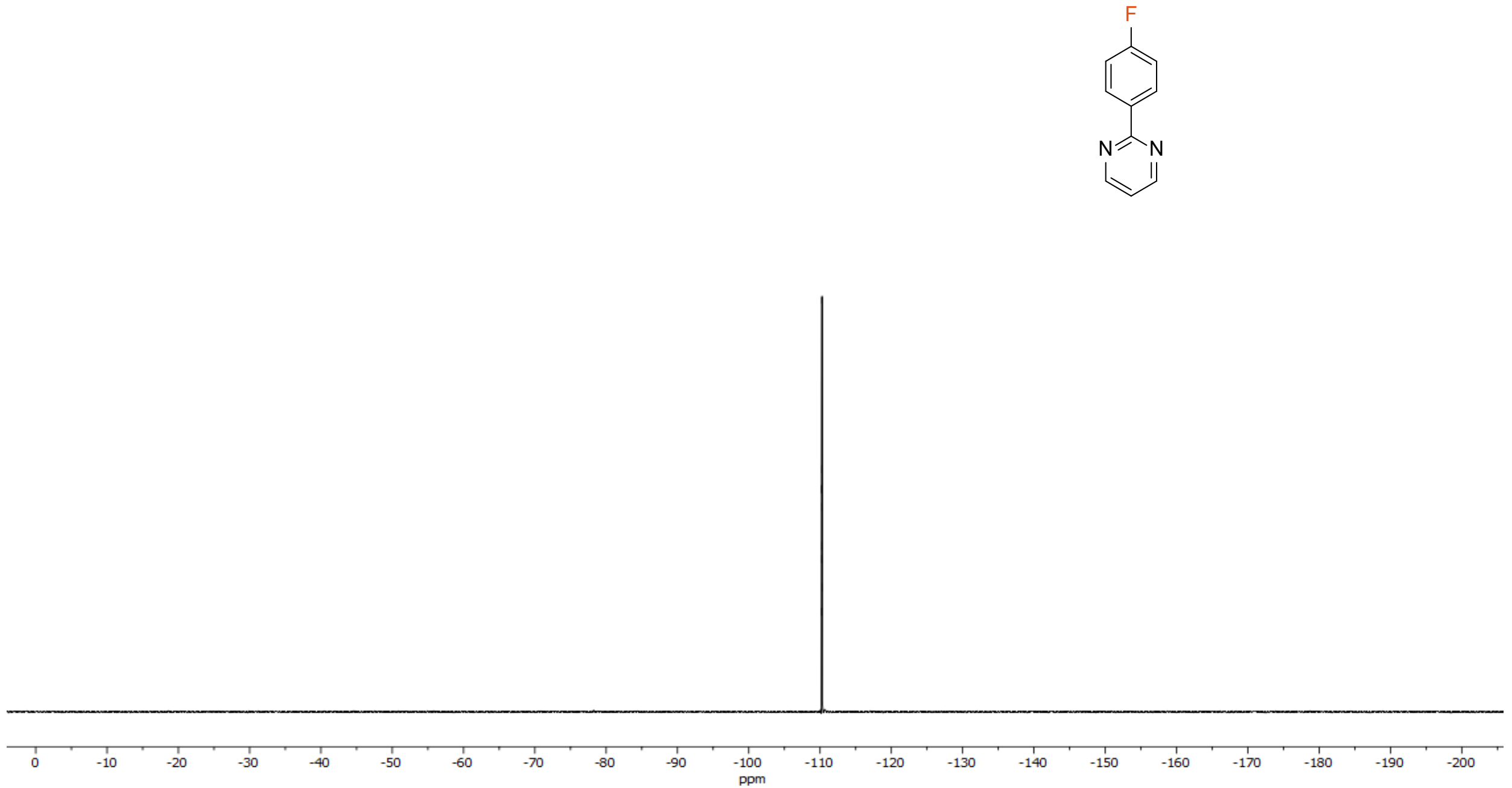
SUPPORTING INFORMATION

S93

${ }^{1} \mathrm{H}$ NMR of 4-fluorobenzamide (20)

$\mathrm{CD}_{3} \mathrm{CN}, 298 \mathrm{~K}$

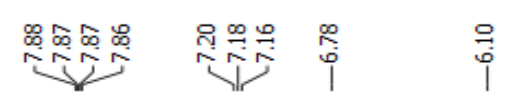<smiles>NC(=O)c1ccc(F)cc1</smiles>

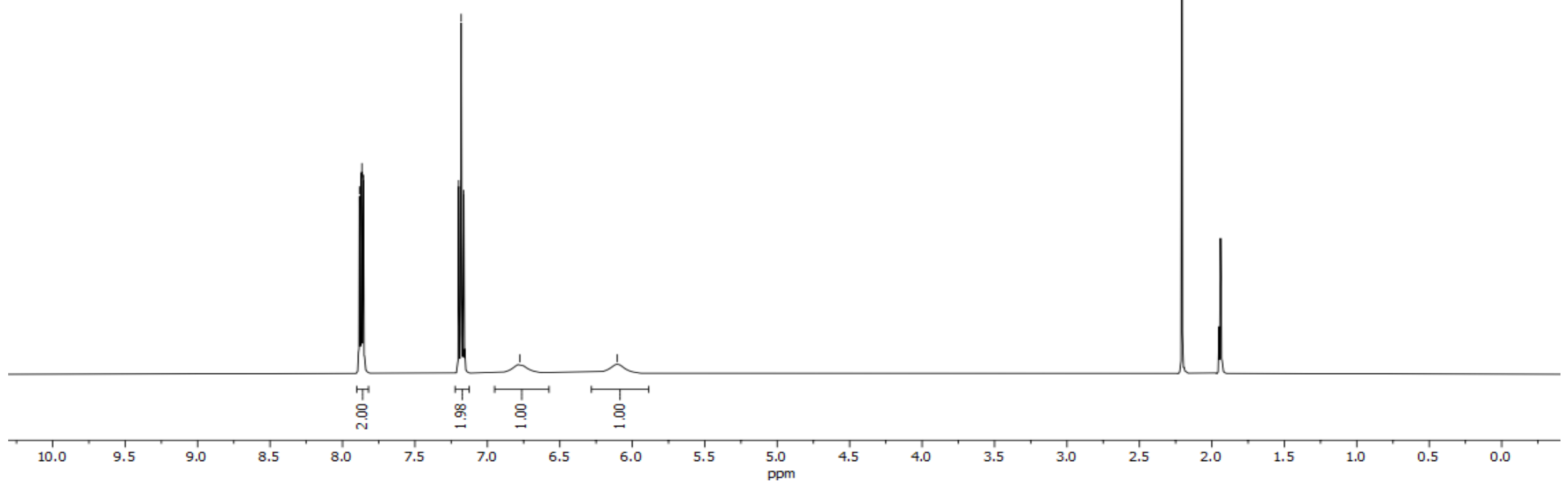


${ }^{13} \mathrm{C}$ NMR of 4 -fluorobenzamide (20)

$\mathrm{CD}_{3} \mathrm{CN}, 298 \mathrm{~K}$

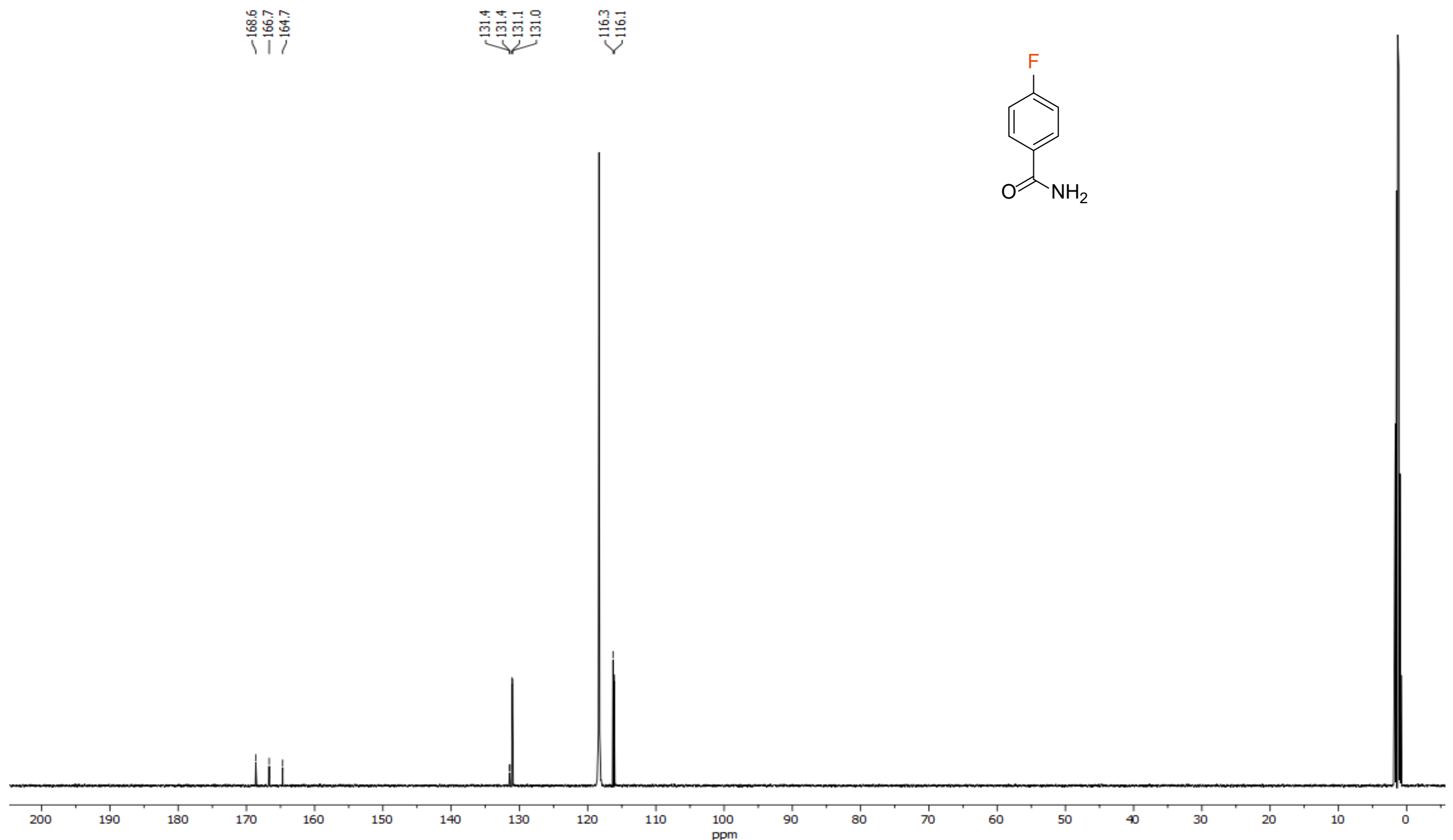


${ }^{19} \mathrm{~F}$ NMR of 4-fluorobenzamide (20)

$\mathrm{CD}_{3} \mathrm{CN}, 298 \mathrm{~K}$
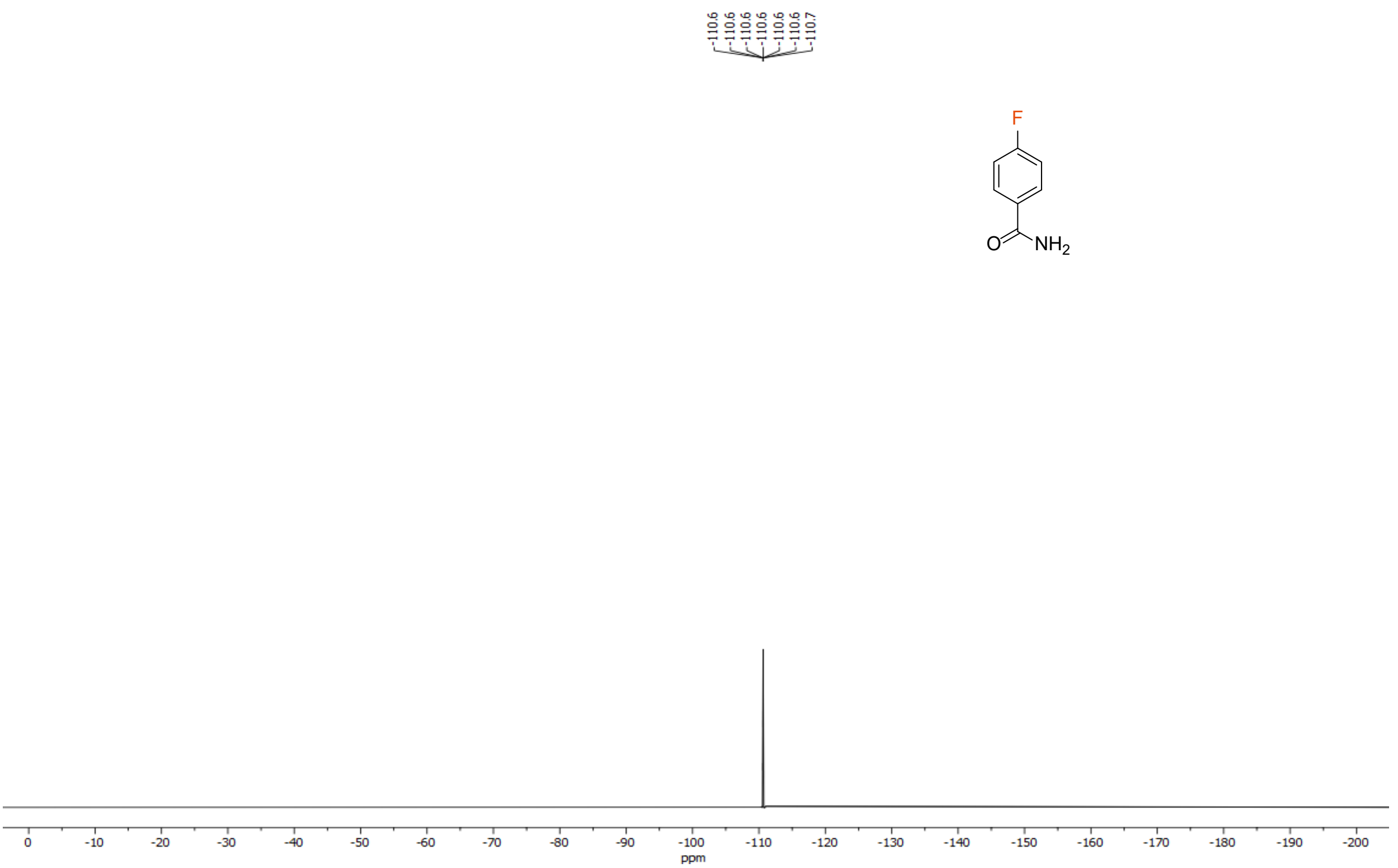
${ }^{1} \mathrm{H}$ NMR of 4-fluorobenzenesulfonamide (21)

$\mathrm{CD}_{3} \mathrm{CN}, 298 \mathrm{~K}$
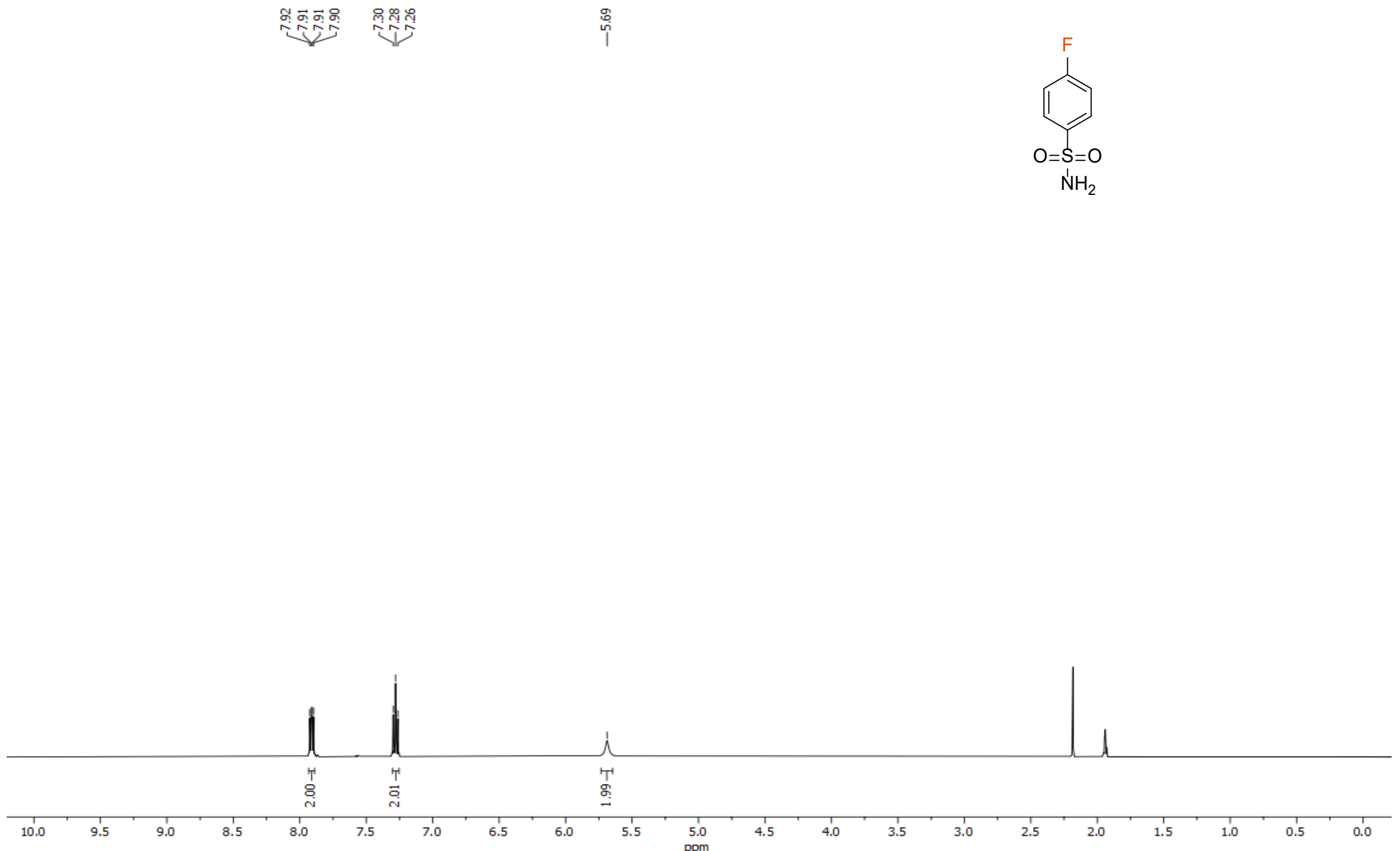
${ }^{13} \mathrm{C}$ NMR of 4 -fluorobenzenesulfonamide (21)

$\mathrm{CD}_{3} \mathrm{CN}, 298 \mathrm{~K}$

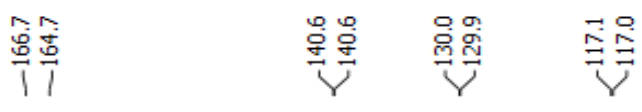
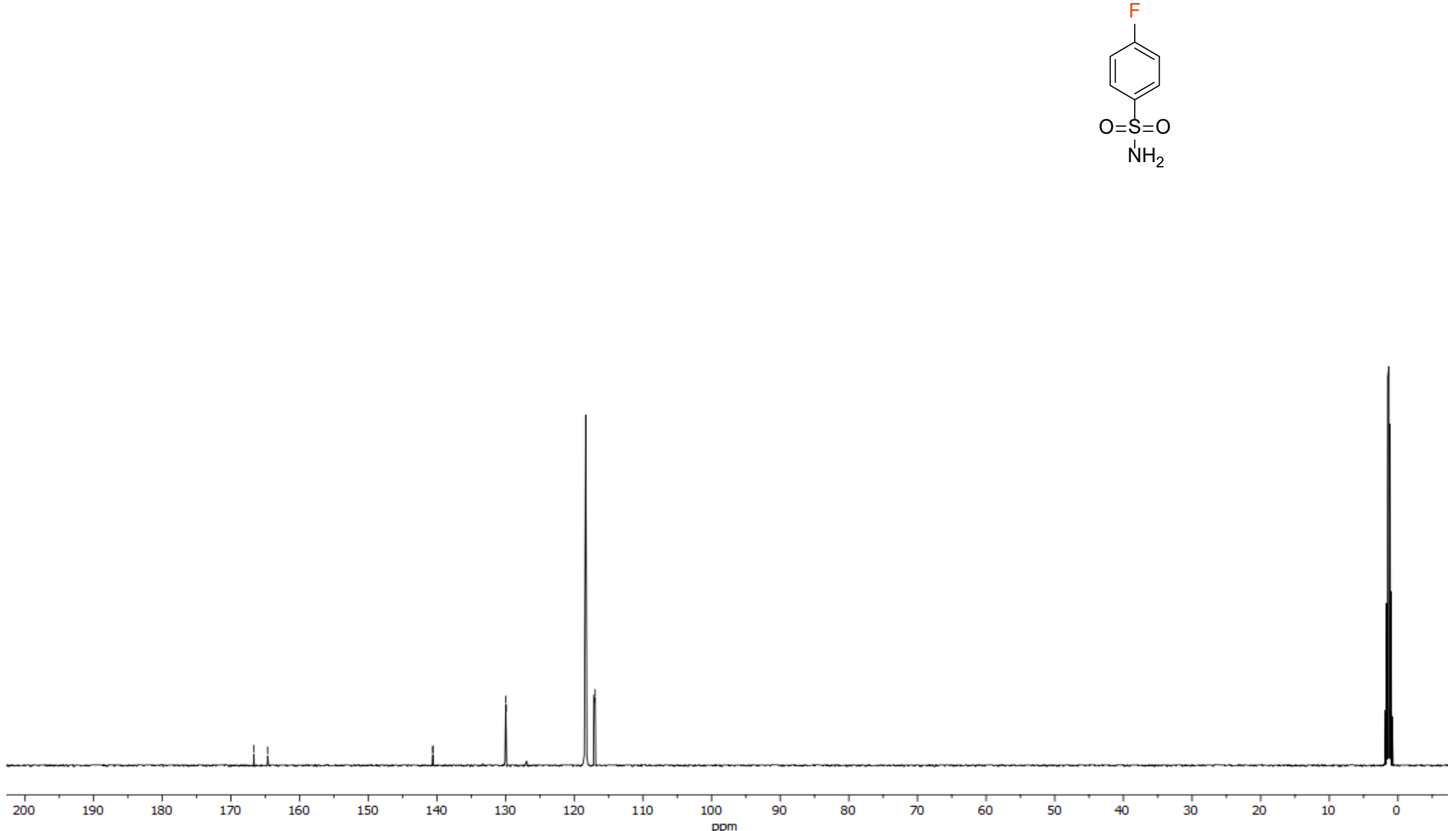
${ }^{19} \mathrm{~F}$ NMR of 4-fluorobenzenesulfonamide (21)

$\mathrm{CD}_{3} \mathrm{CN}, 298 \mathrm{~K}$

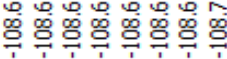

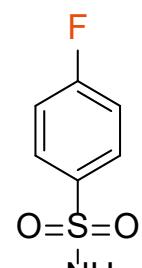

$\mathrm{NH}_{2}$

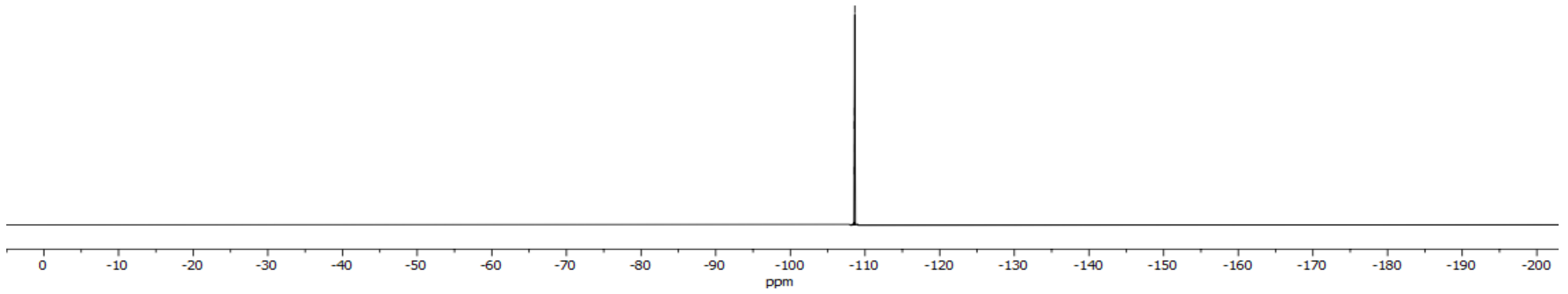


${ }^{1} \mathrm{H}$ NMR of diflunisal acetate derivative 22

$\mathrm{CDCl}_{3}, 298 \mathrm{~K}$

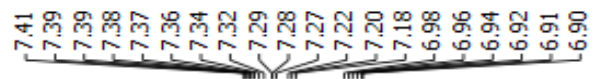

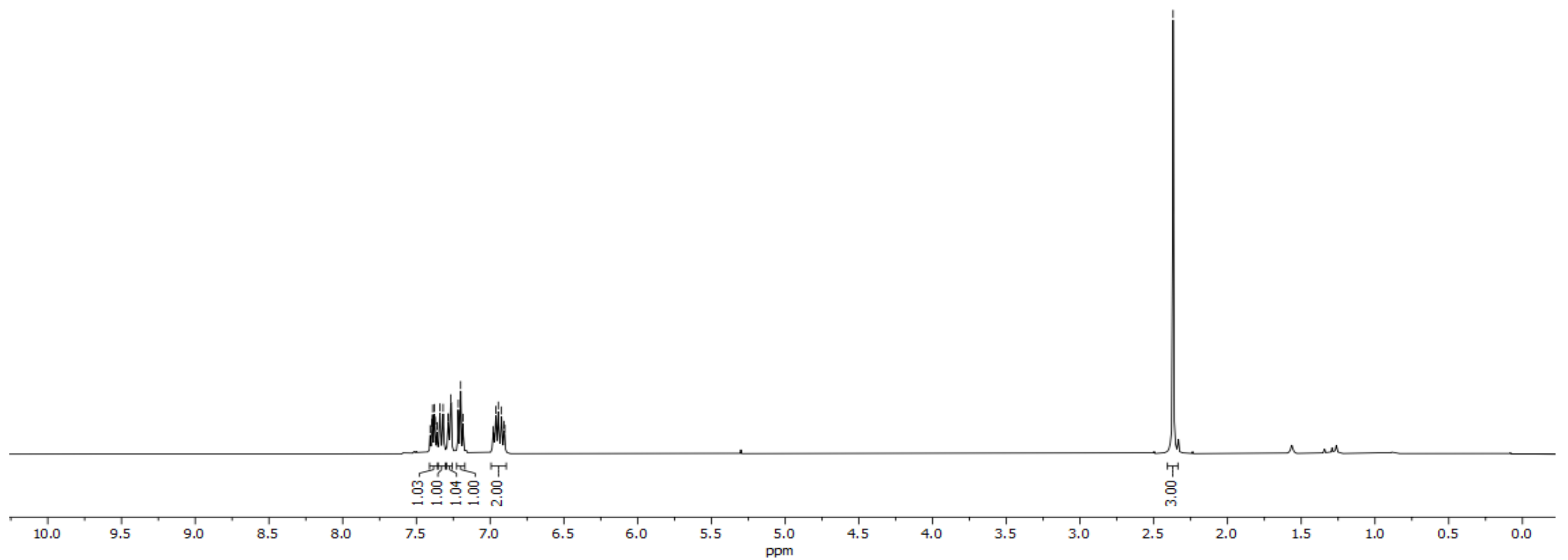


${ }^{13} \mathrm{C}$ NMR of diflunisal acetate derivative 22

$\mathrm{CDCl}_{3}, 298 \mathrm{~K}$
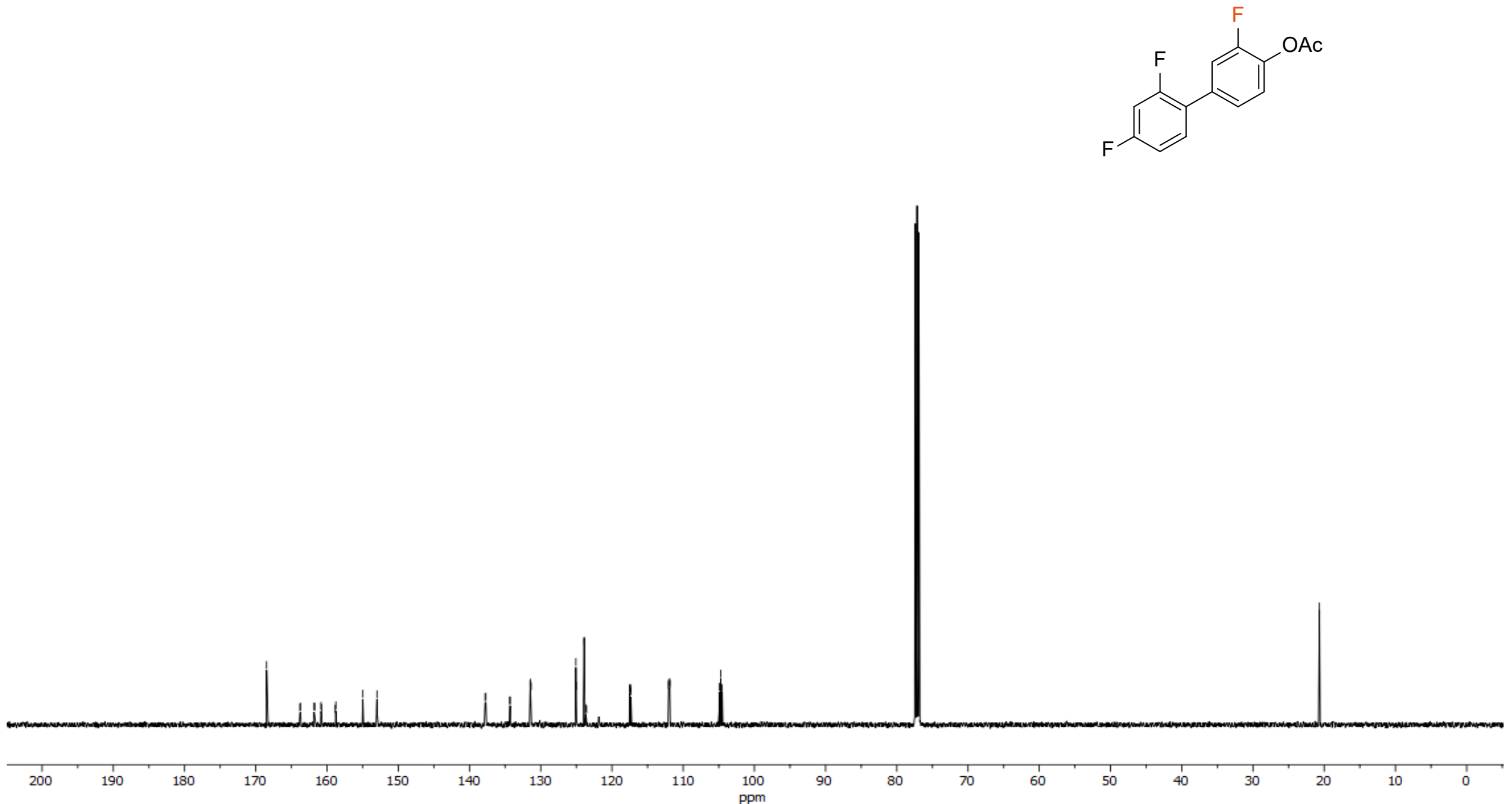
${ }^{19} \mathrm{~F}$ NMR of diflunisal acetate derivative 22

$\mathrm{CDCl}_{3}, 298 \mathrm{~K}$
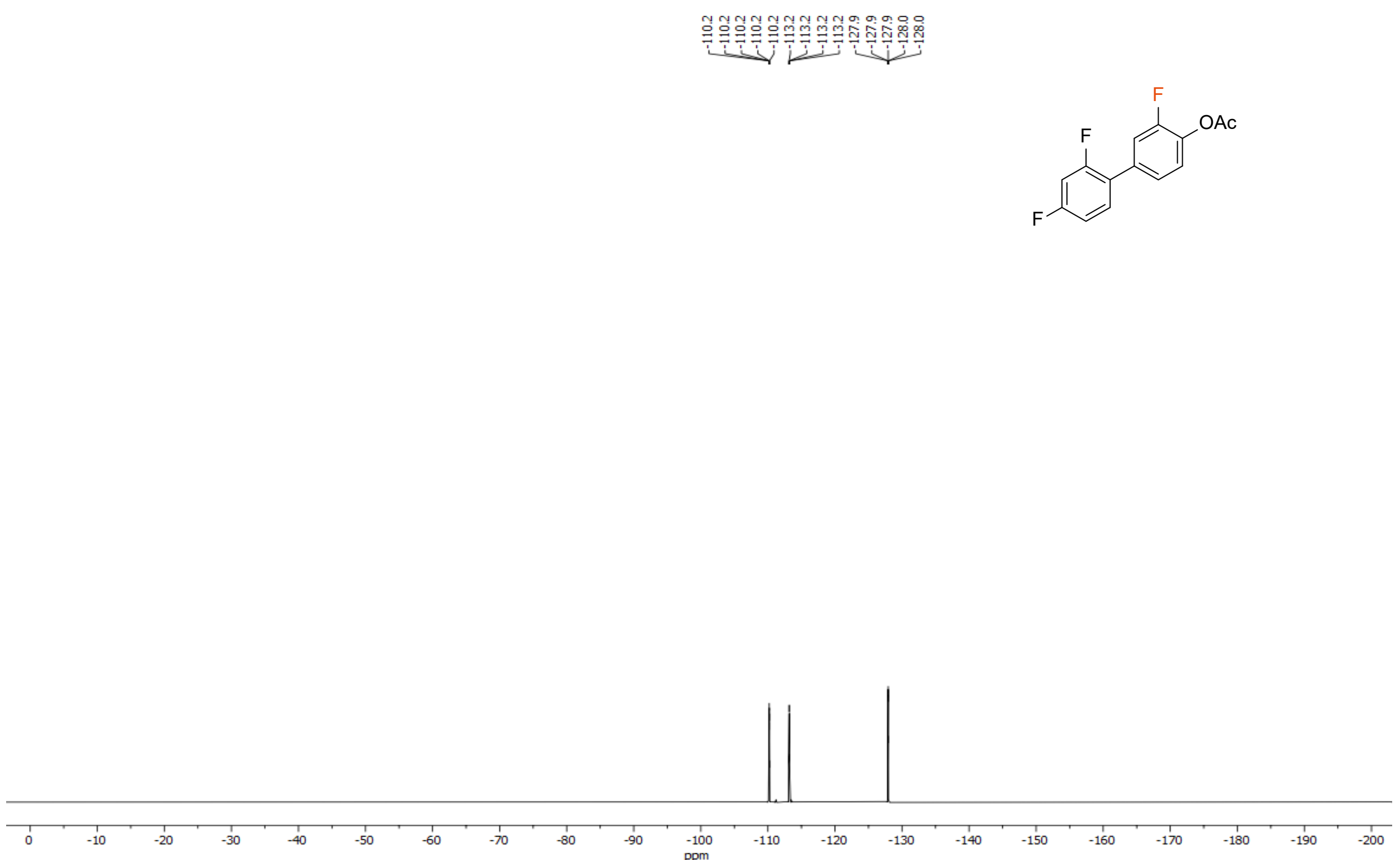


\section{${ }^{1} \mathrm{H}$ NMR of oxydecarboxylation product 22a}

$\mathrm{CDCl}_{3}, 298 \mathrm{~K}$

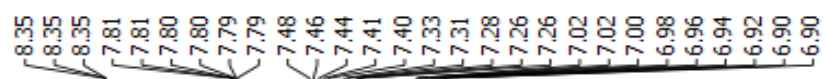
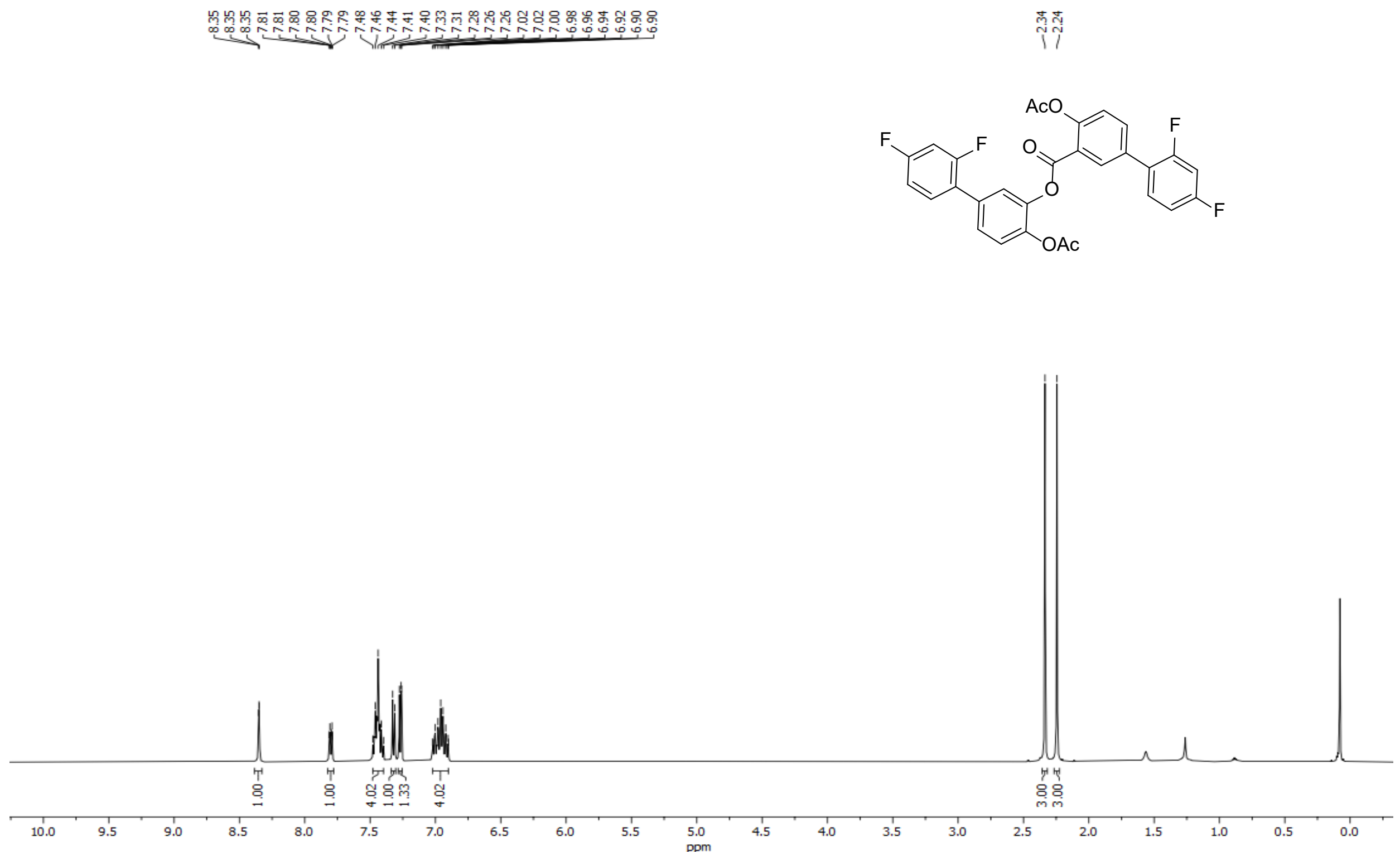


\section{${ }^{13} \mathrm{C}$ NMR of oxydecarboxylation product $22 \mathrm{a}$}

$\mathrm{CDCl}_{3}, 298 \mathrm{~K}$

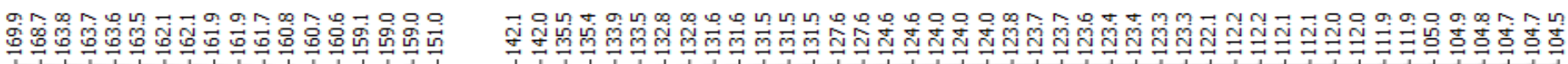

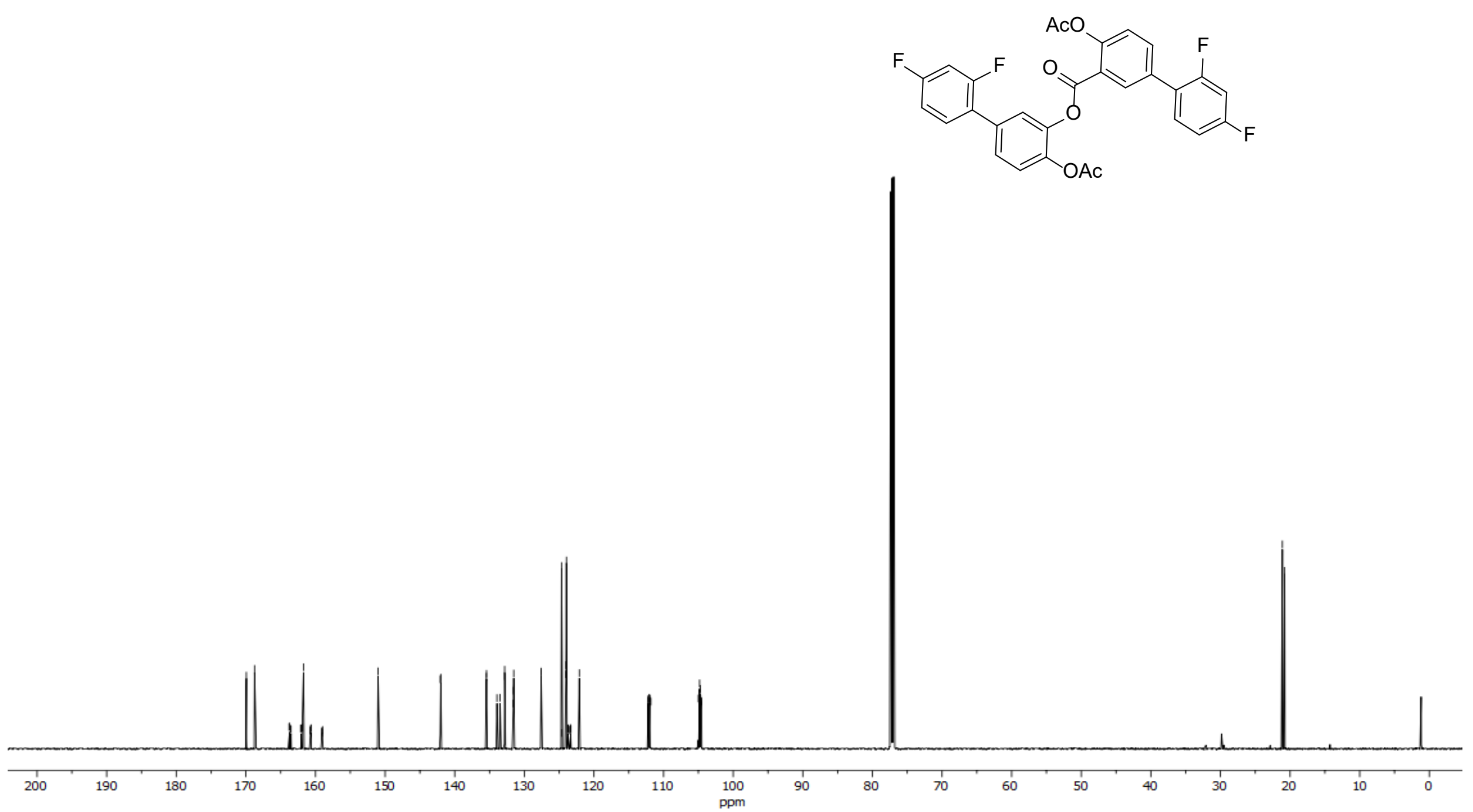


${ }^{19} \mathrm{~F}$ NMR of oxydecarboxylation product $22 \mathrm{a}$

$\mathrm{CDCl}_{3}, 298 \mathrm{~K}$

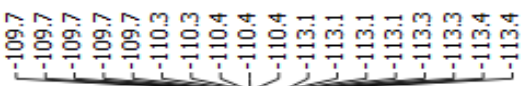
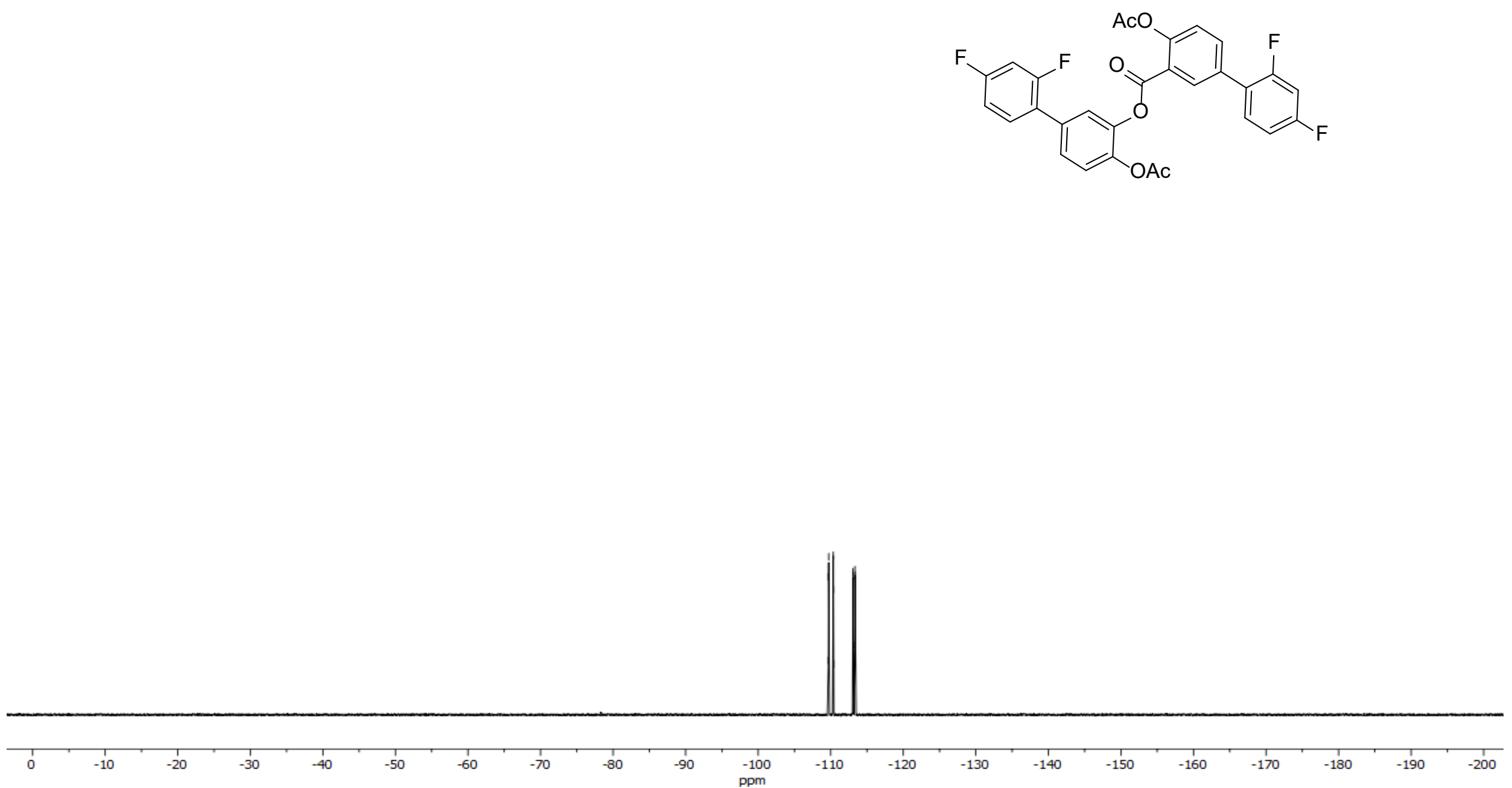
${ }^{1} \mathrm{H}$ NMR of (+)-menthol derivative 23

$\mathrm{CDCl}_{3}, 298 \mathrm{~K}$

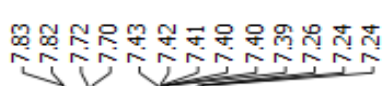

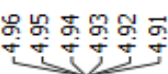

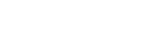

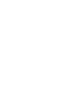

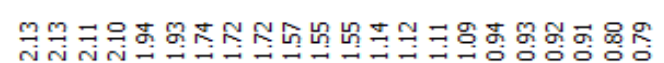
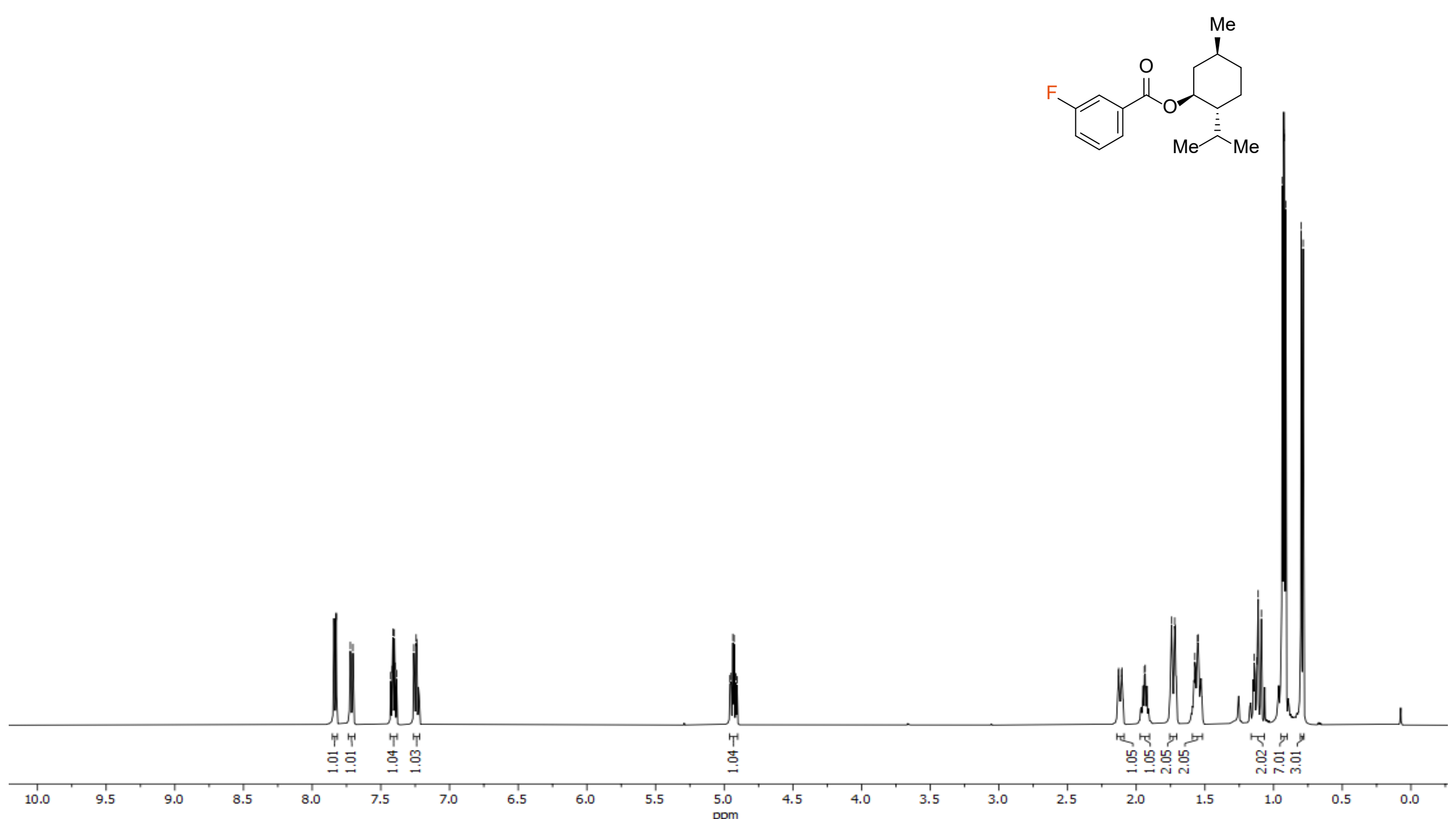
${ }^{13} \mathrm{C}$ NMR of (+)-menthol derivative 23

$\mathrm{CDCl}_{3}, 298 \mathrm{~K}$
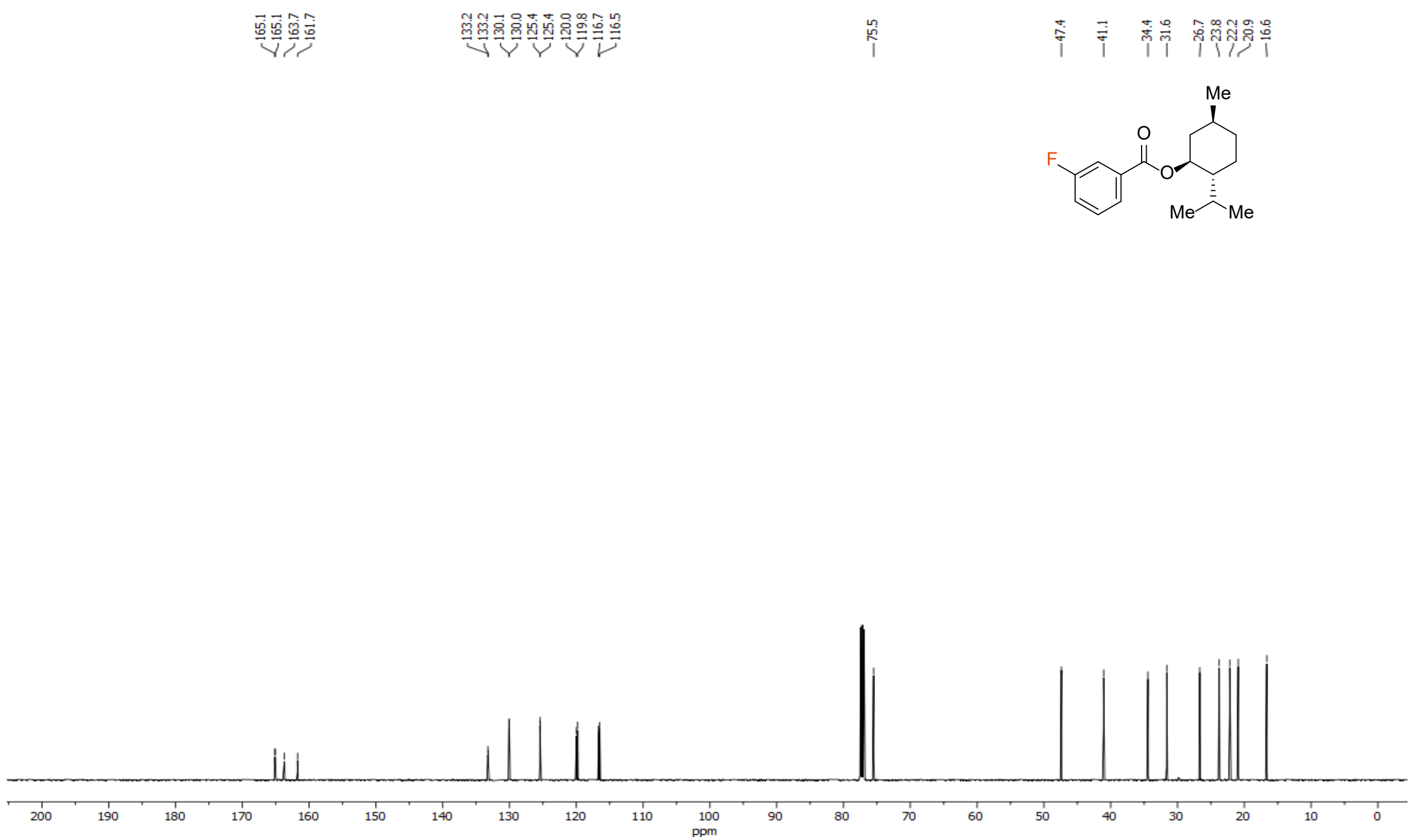
${ }^{19}$ F NMR of (+)-menthol derivative 23

$\mathrm{CDCl}_{3}, 298 \mathrm{~K}$
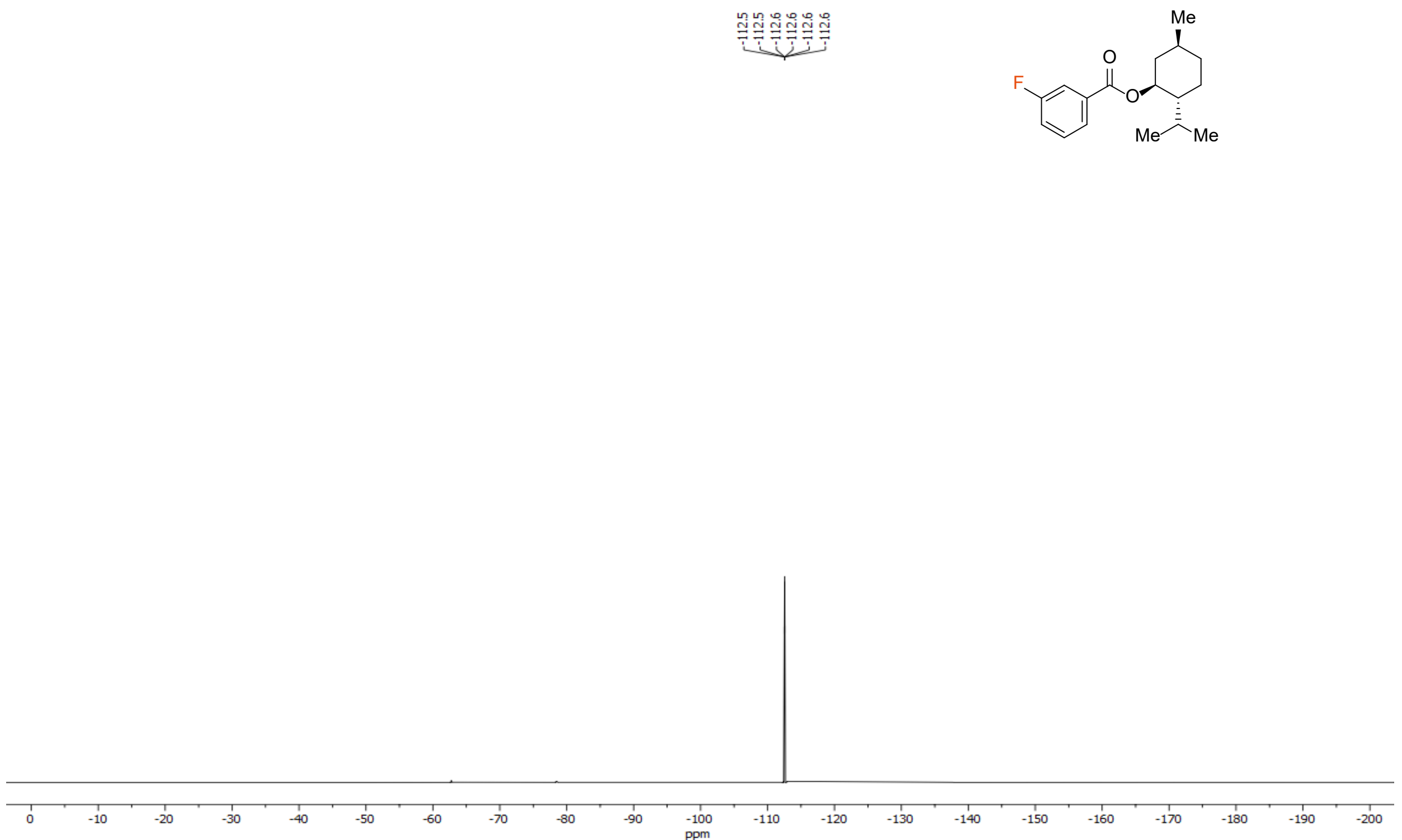
${ }^{1} \mathrm{H}$ NMR of 4-fluorophenyl benzoate (24)

$\mathrm{CDCl}_{3}, 298 \mathrm{~K}$

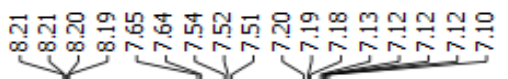

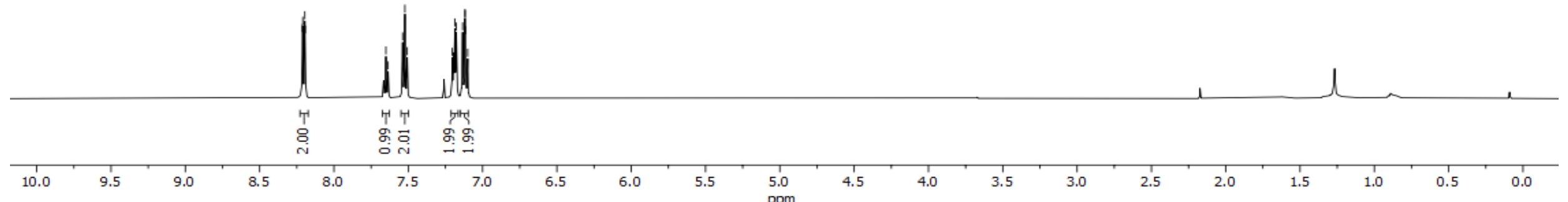




\section{${ }^{13} \mathrm{C}$ NMR of 4-fluorophenyl benzoate (24)}

$\mathrm{CDCl}_{3}, 298 \mathrm{~K}$

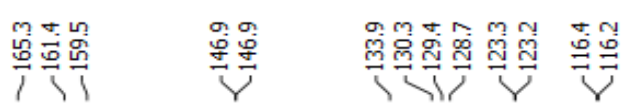
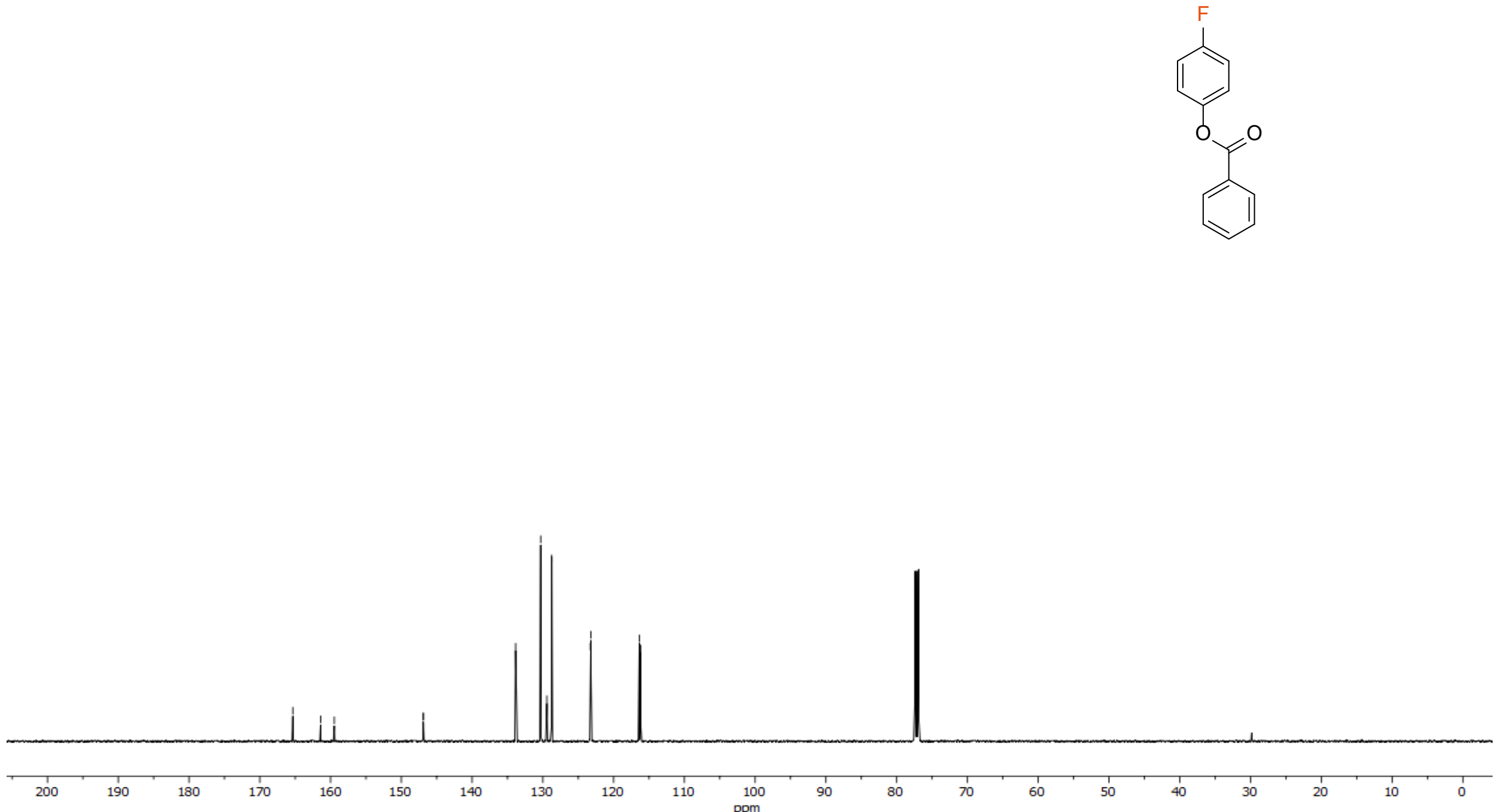
${ }^{19} \mathrm{~F}$ NMR of 4-fluorophenyl benzoate (24)

$\mathrm{CDCl}_{3}, 298 \mathrm{~K}$

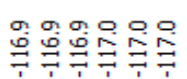
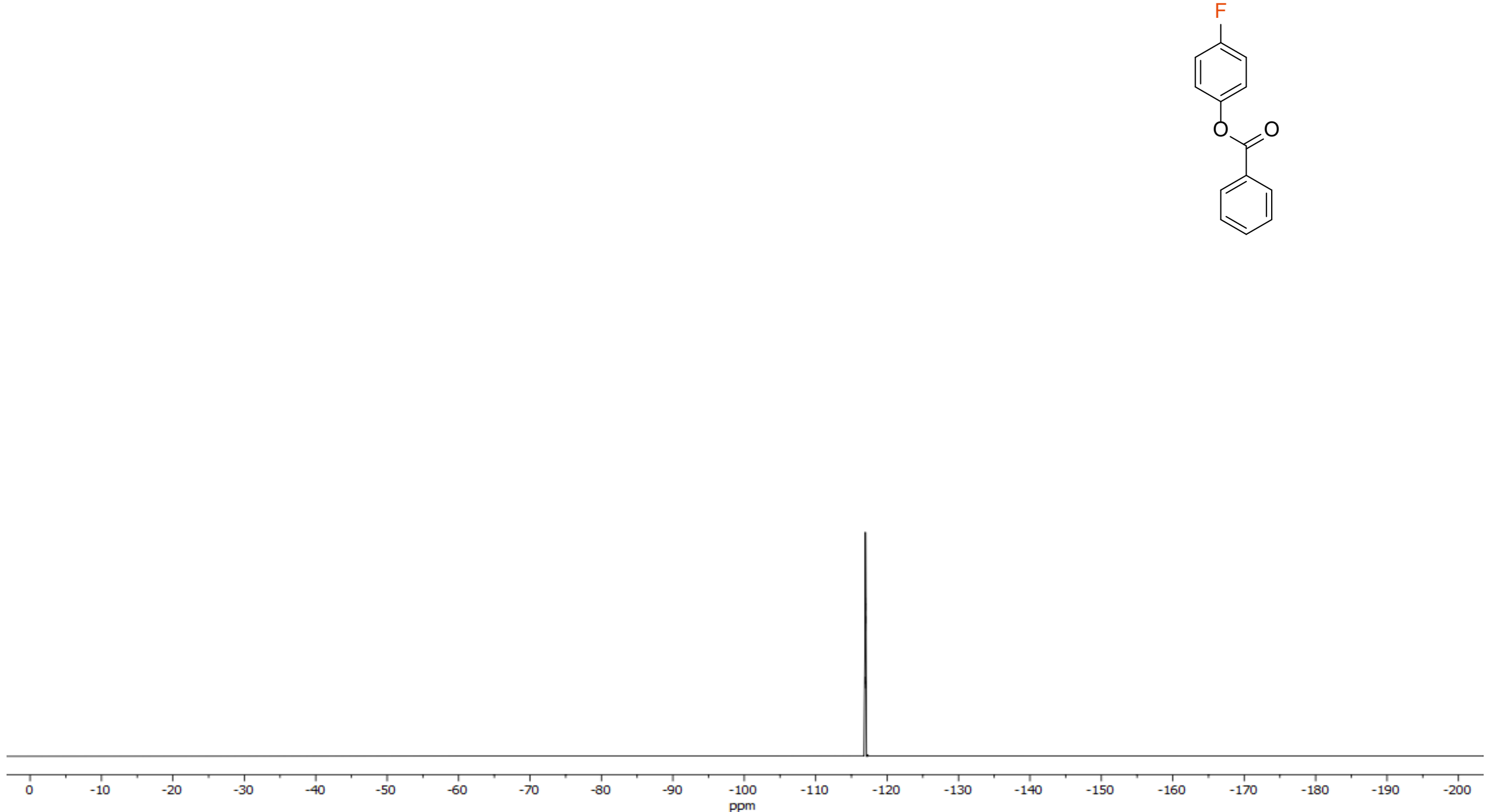
${ }^{1} \mathrm{H}$ NMR of 2-fluoro-4-methoxyquinoline (26)

$\mathrm{CD}_{3} \mathrm{CN}, 298 \mathrm{~K}$

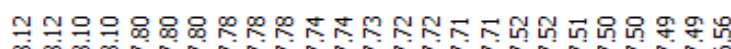

品

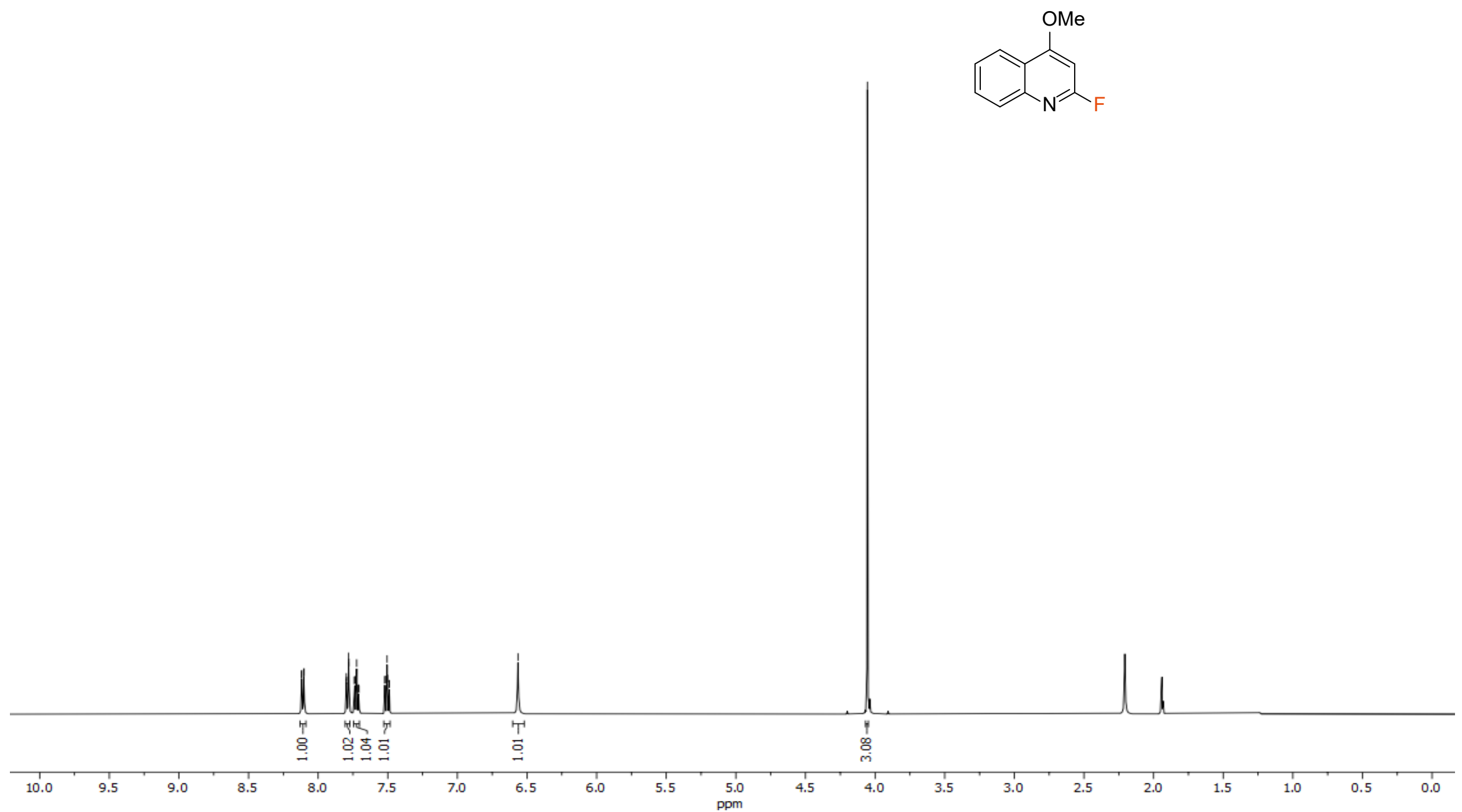


${ }^{13} \mathrm{C}$ NMR of 2-fluoro-4-methoxyquinoline (26)

$\mathrm{CD}_{3} \mathrm{CN}, 298 \mathrm{~K}$

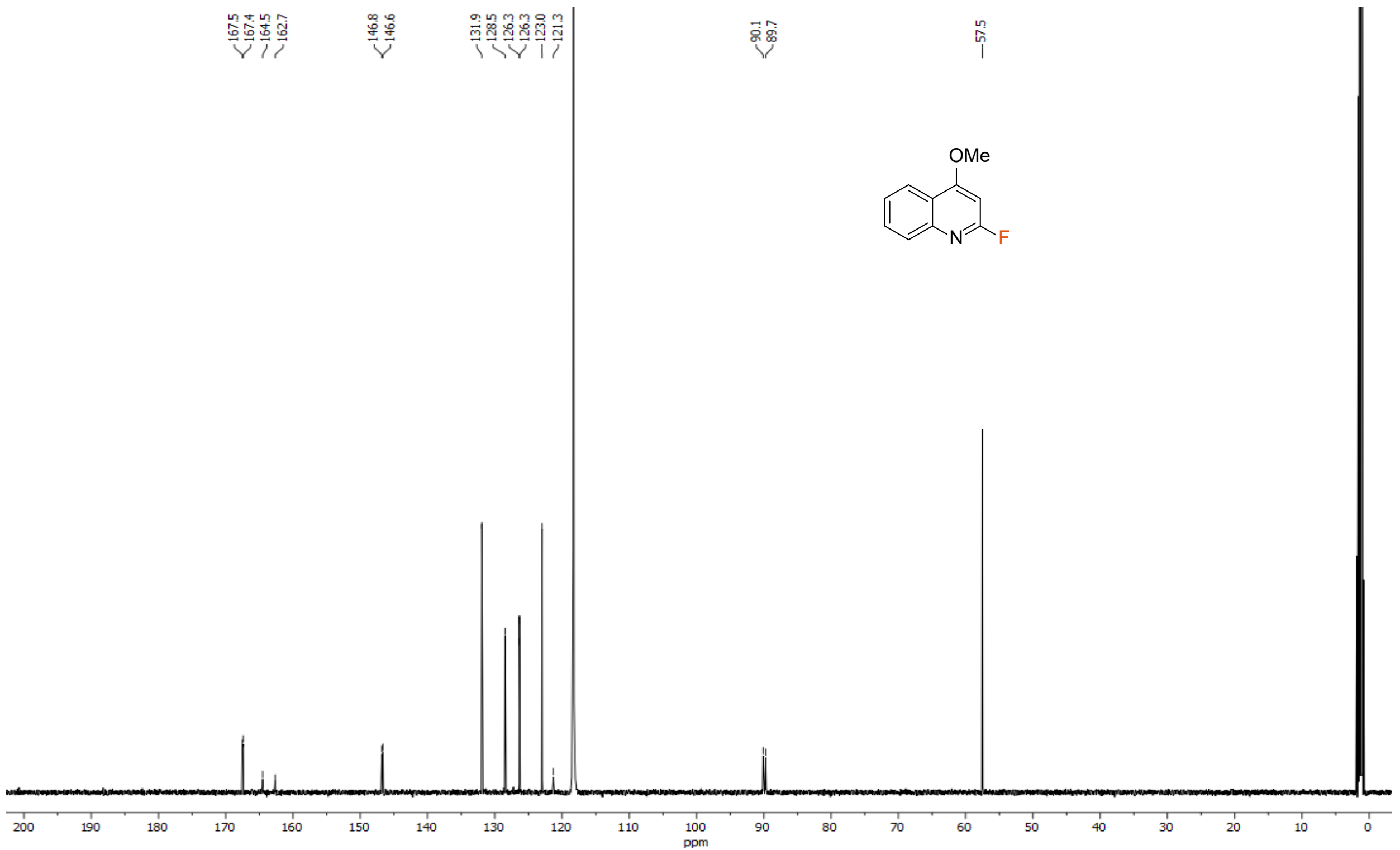


${ }^{19} \mathrm{~F}$ NMR of 2-fluoro-4-methoxyquinoline (26)

$\mathrm{CD}_{3} \mathrm{CN}, 298 \mathrm{~K}$

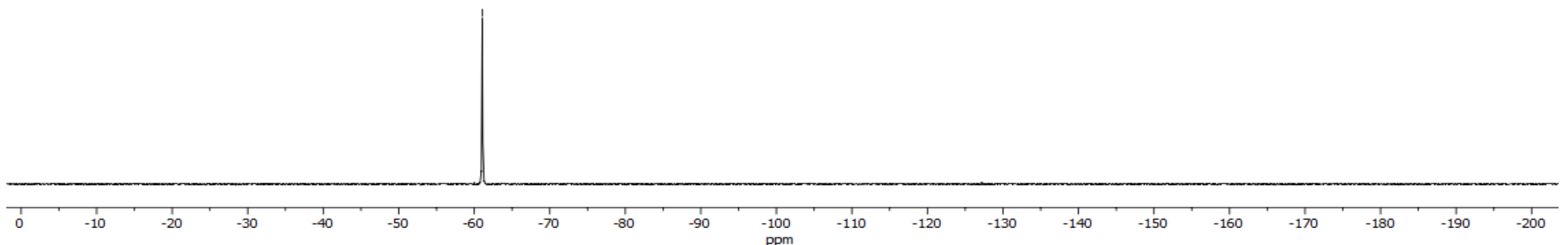


${ }^{1} \mathrm{H}$ NMR of $\mathrm{N}$-succinimidyl 4-fluorobenzoate (27)

$\mathrm{CDCl}_{3}, 298 \mathrm{~K}$
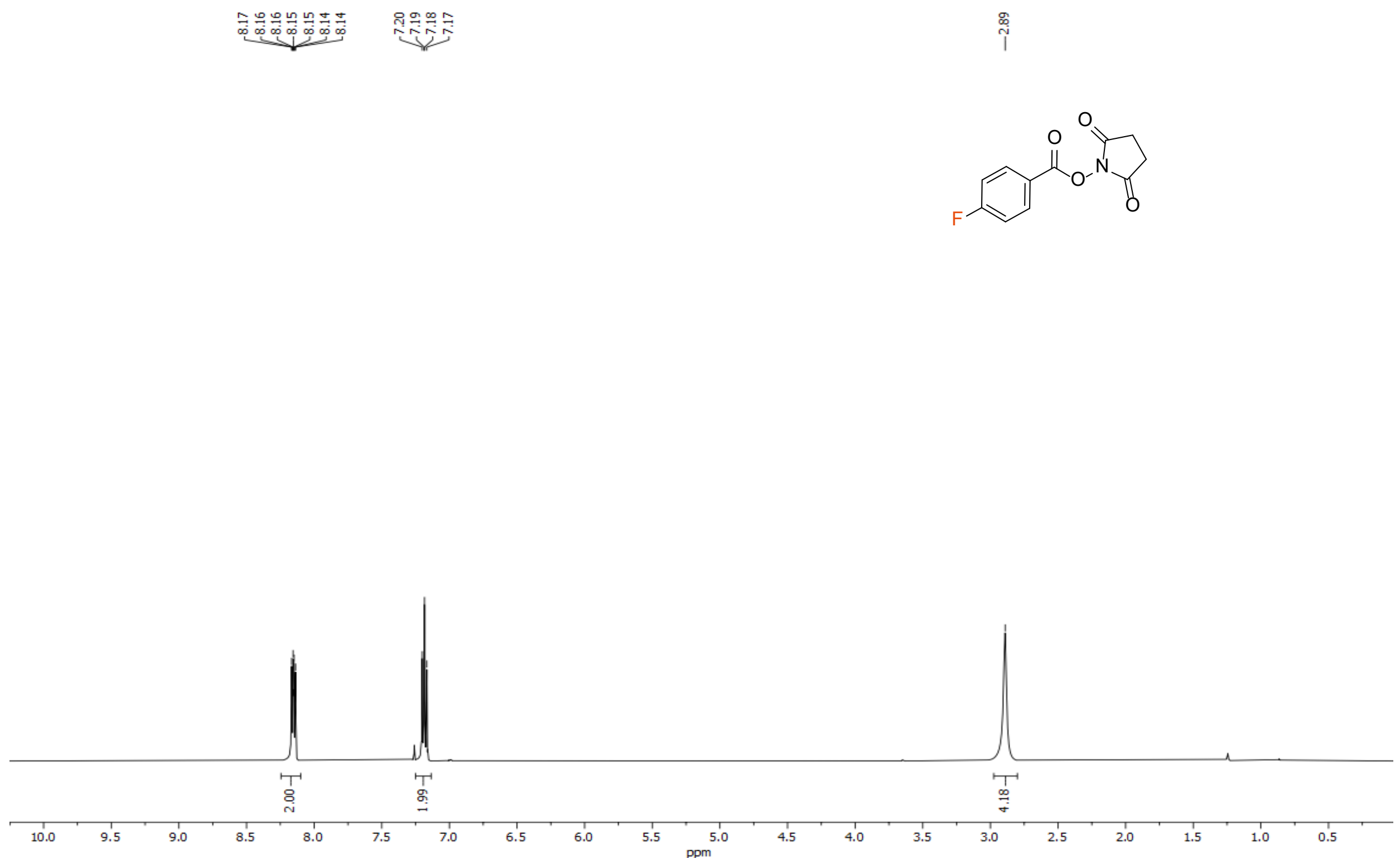
${ }^{13} \mathrm{C}$ NMR of $\mathrm{N}$-succinimidyl 4-fluorobenzoate (27)

$\mathrm{CDCl}_{3}, 298 \mathrm{~K}$
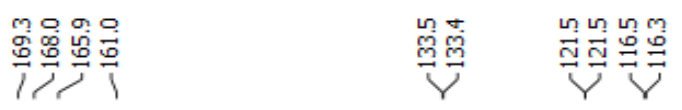

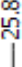
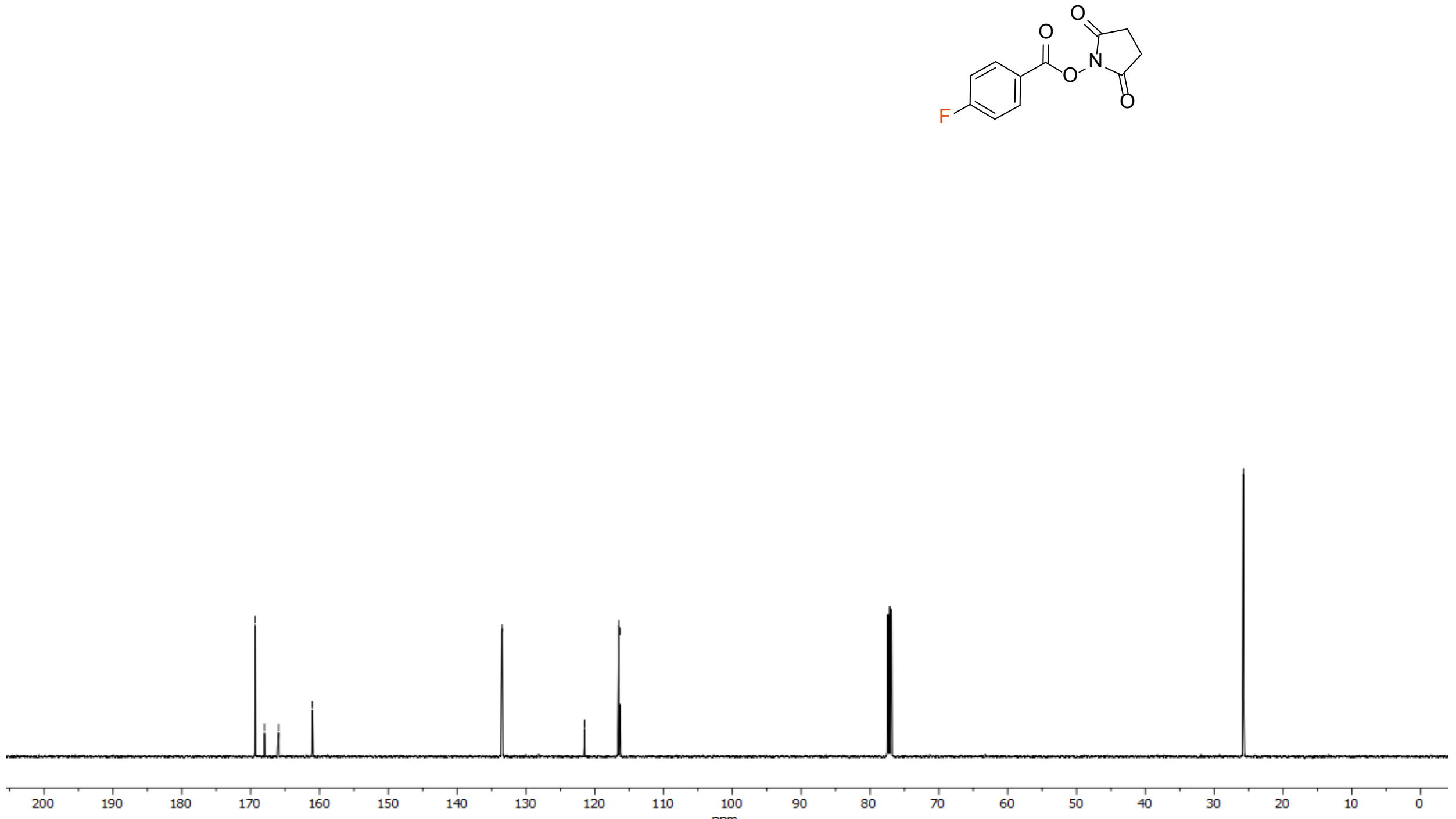
${ }^{19} \mathrm{~F}$ NMR of $\mathrm{N}$-succinimidyl 4-fluorobenzoate (27)

$\mathrm{CDCl}_{3}, 298 \mathrm{~K}$
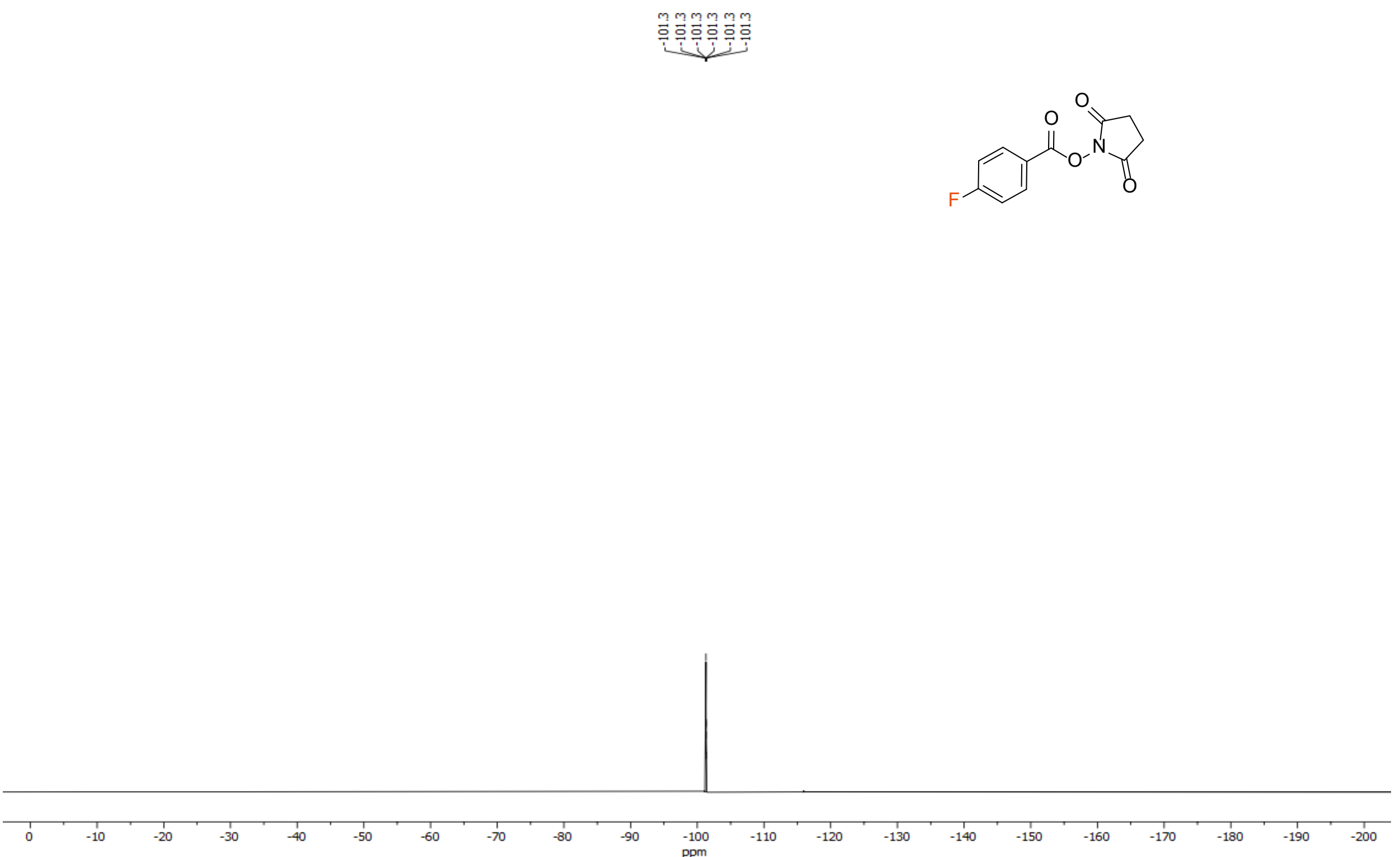


\section{${ }^{1} \mathrm{H}$ NMR of fenofibrate analogue 28}

$\mathrm{CDCl}_{3}, 298 \mathrm{~K}$

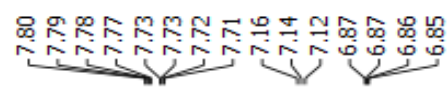

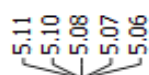

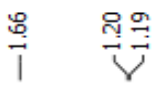
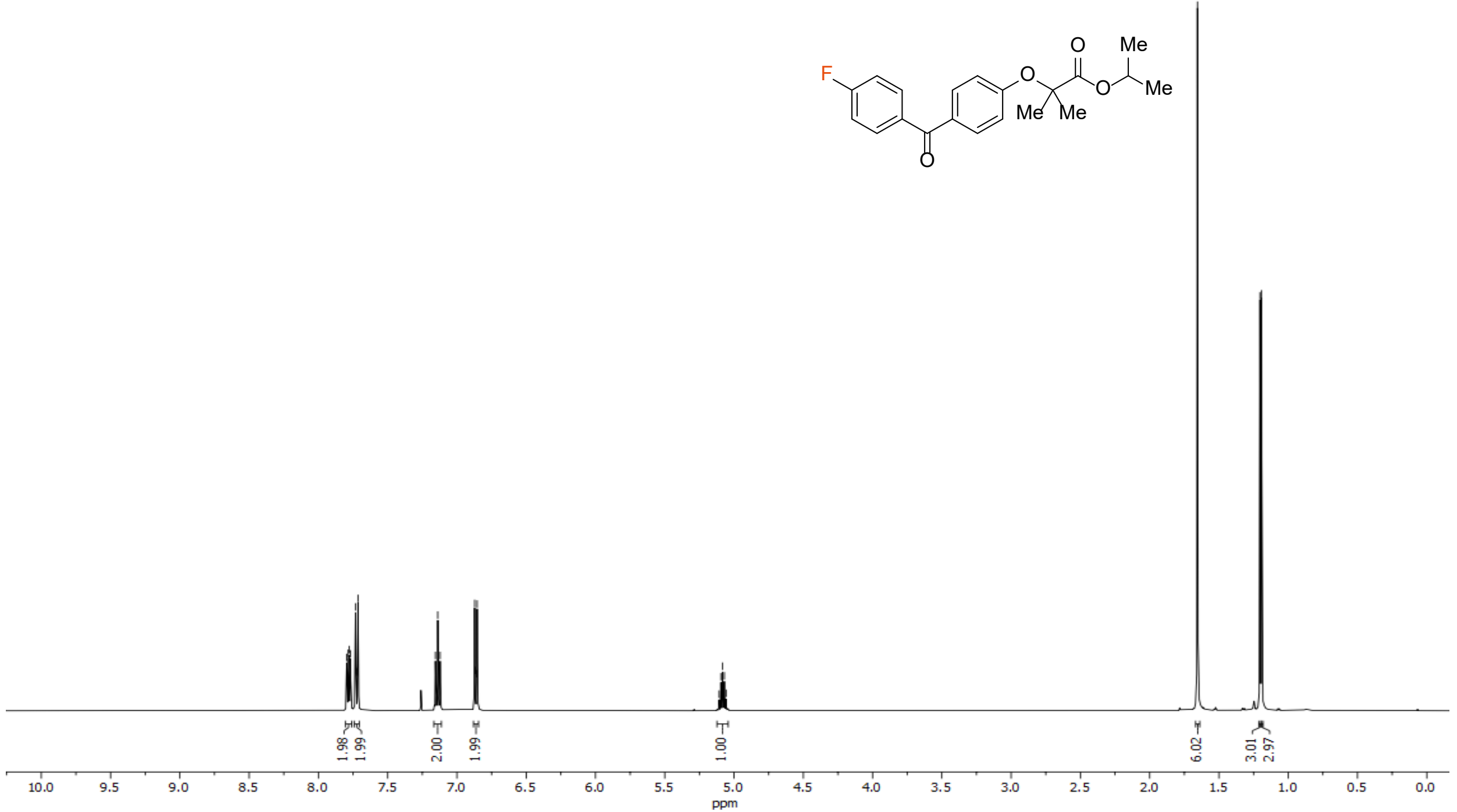


\section{${ }^{13} \mathrm{C}$ NMR of fenofibrate analogue 28}

$\mathrm{CDCl}_{3}, 298 \mathrm{~K}$

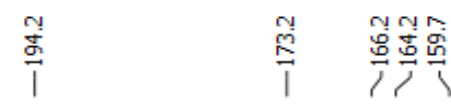

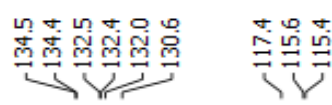

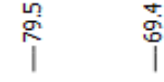

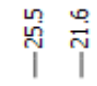
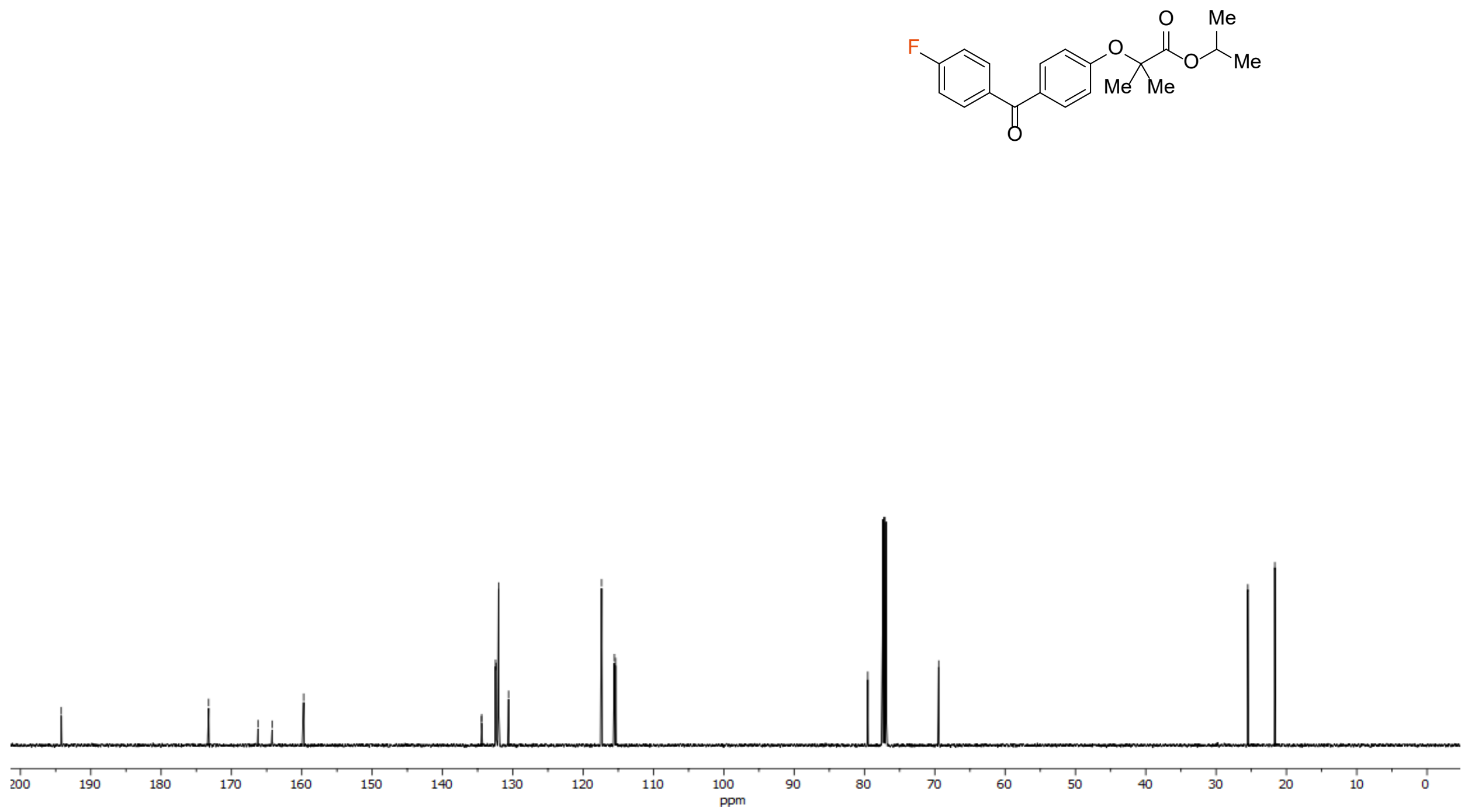
${ }^{19} \mathrm{~F}$ NMR of fenofibrate analogue 28

$\mathrm{CDCl}_{3}, 298 \mathrm{~K}$

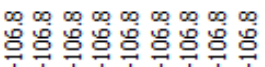
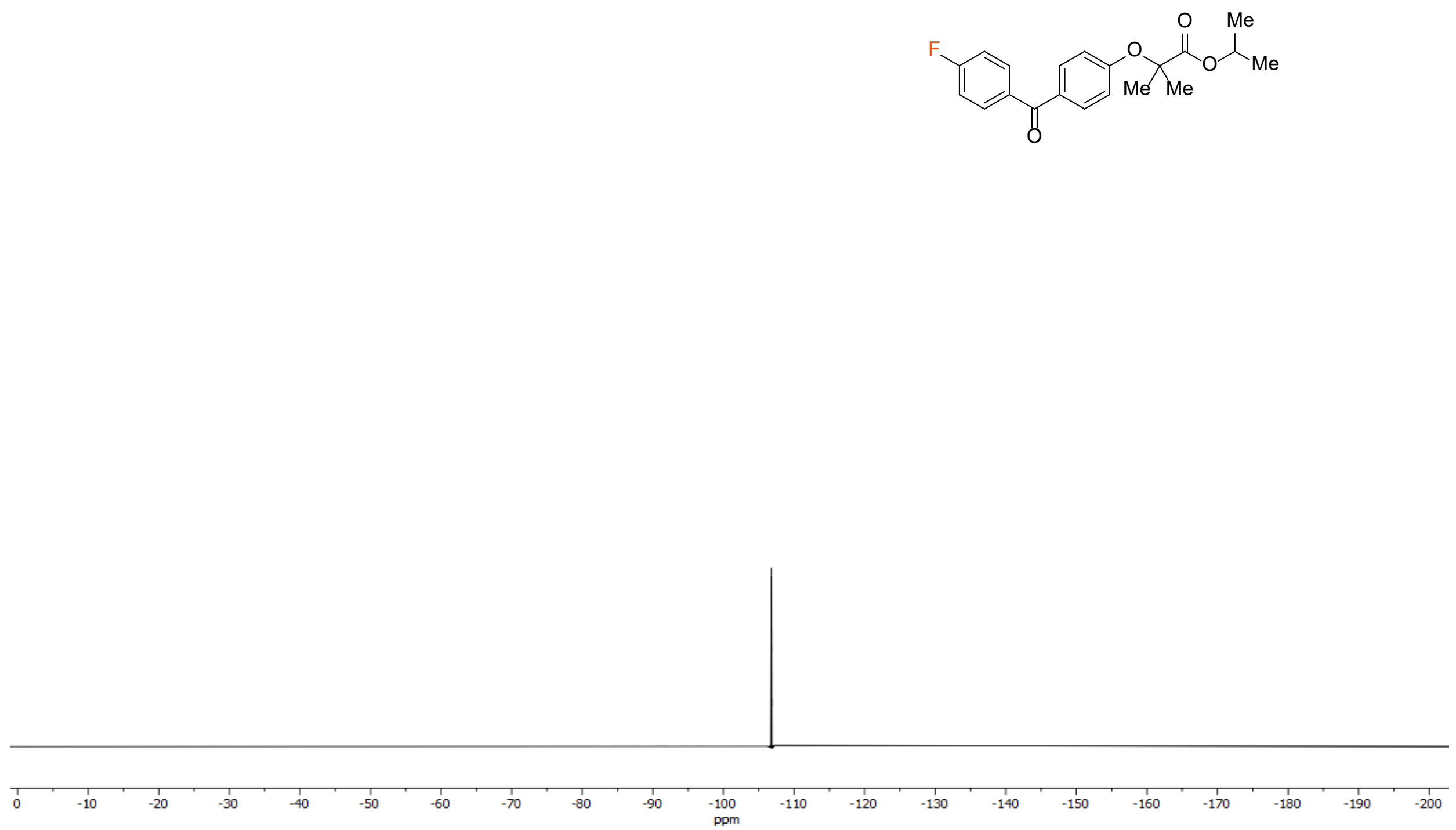


\section{${ }^{1} \mathrm{H}$ NMR of D-glucose derivative S2}

$\mathrm{CDCl}_{3}, 298 \mathrm{~K}$
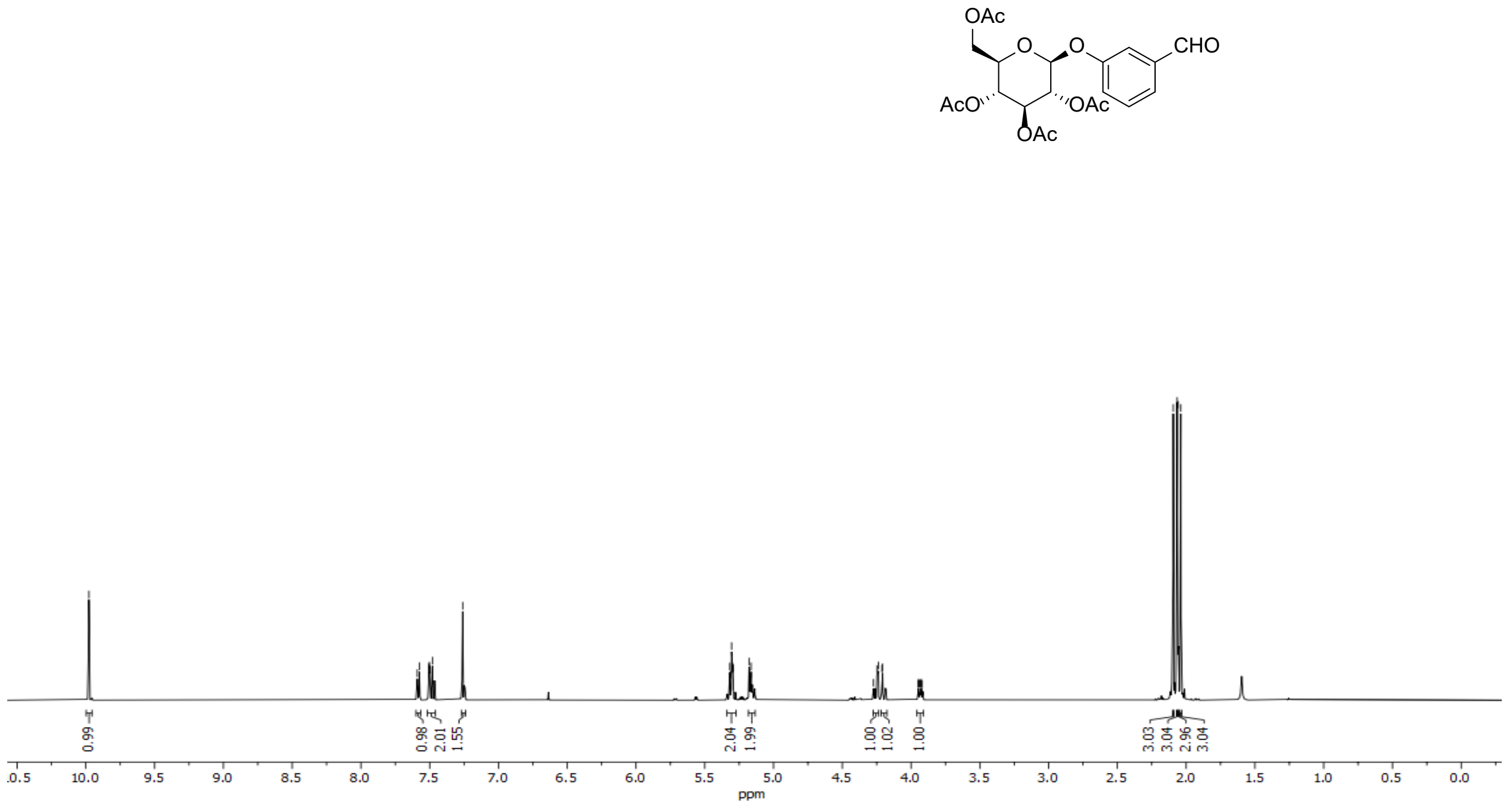
${ }^{13} \mathrm{C}$ NMR of D-glucose derivative $\mathrm{S} 2$

$\mathrm{CDCl}_{3}, 298 \mathrm{~K}$

।

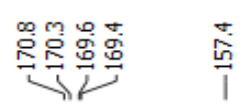

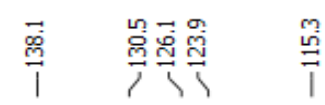

$\stackrel{\infty}{i}$

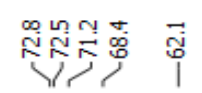

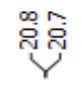

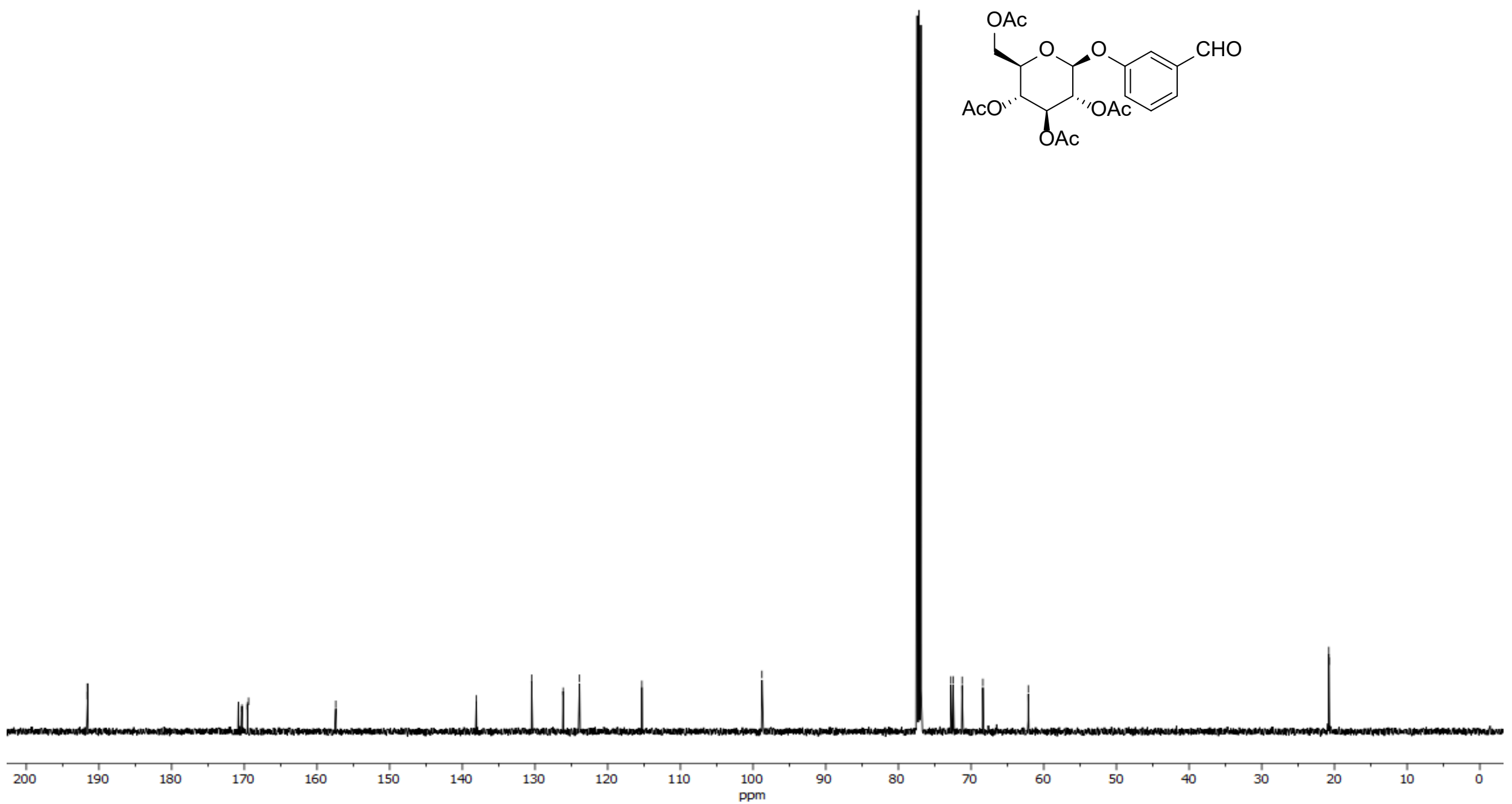




\section{${ }^{1} \mathrm{H}$ NMR of D-glucose derivative S3}

$\mathrm{CDCl}_{3}, 298 \mathrm{~K}$

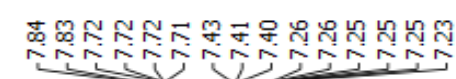

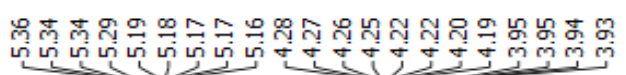
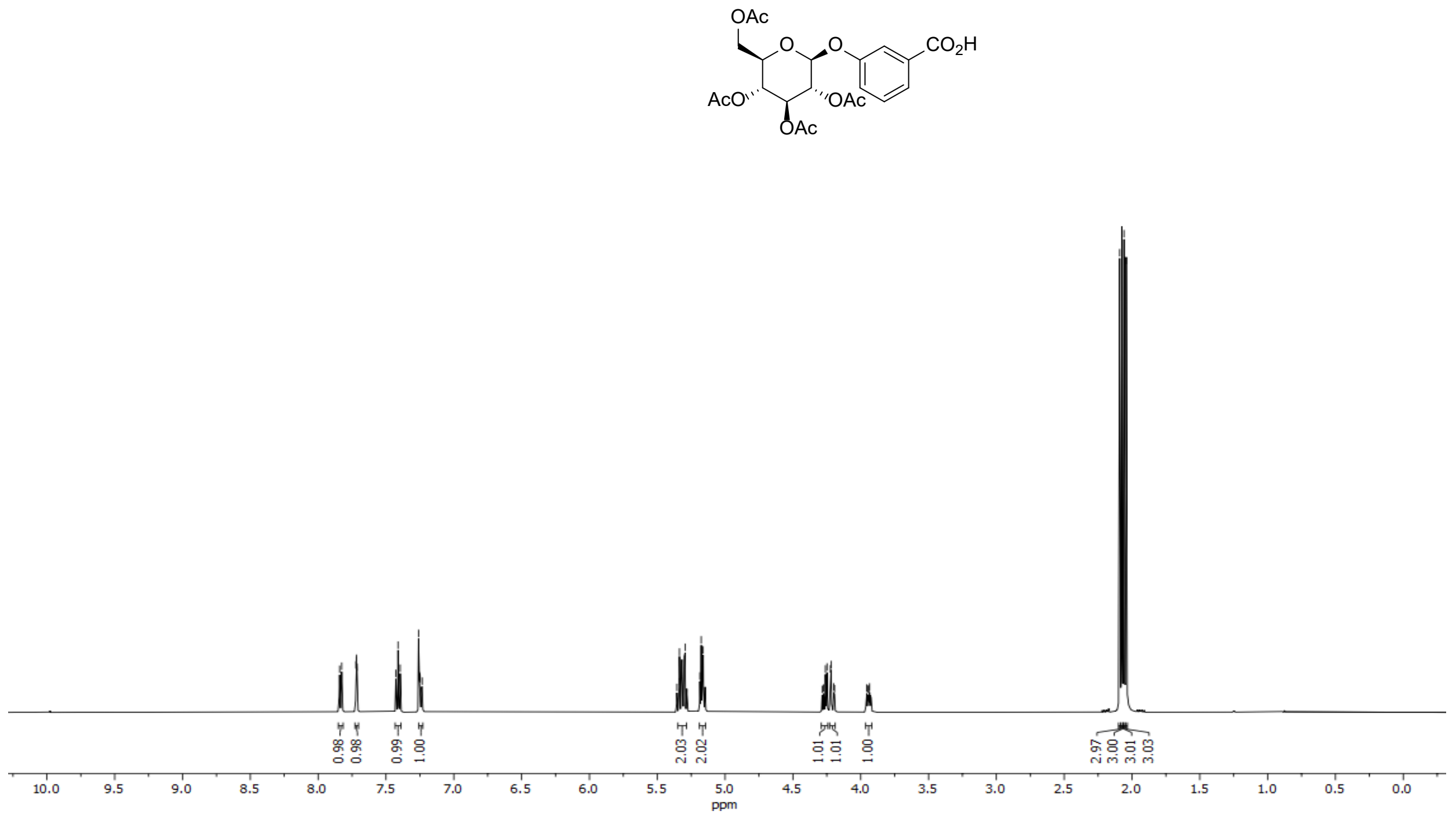
${ }^{13} \mathrm{C}$ NMR of D-glucose derivative S3

$\mathrm{CDCl}_{3}, 298 \mathrm{~K}$

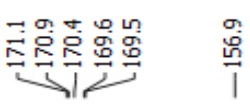

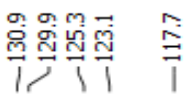
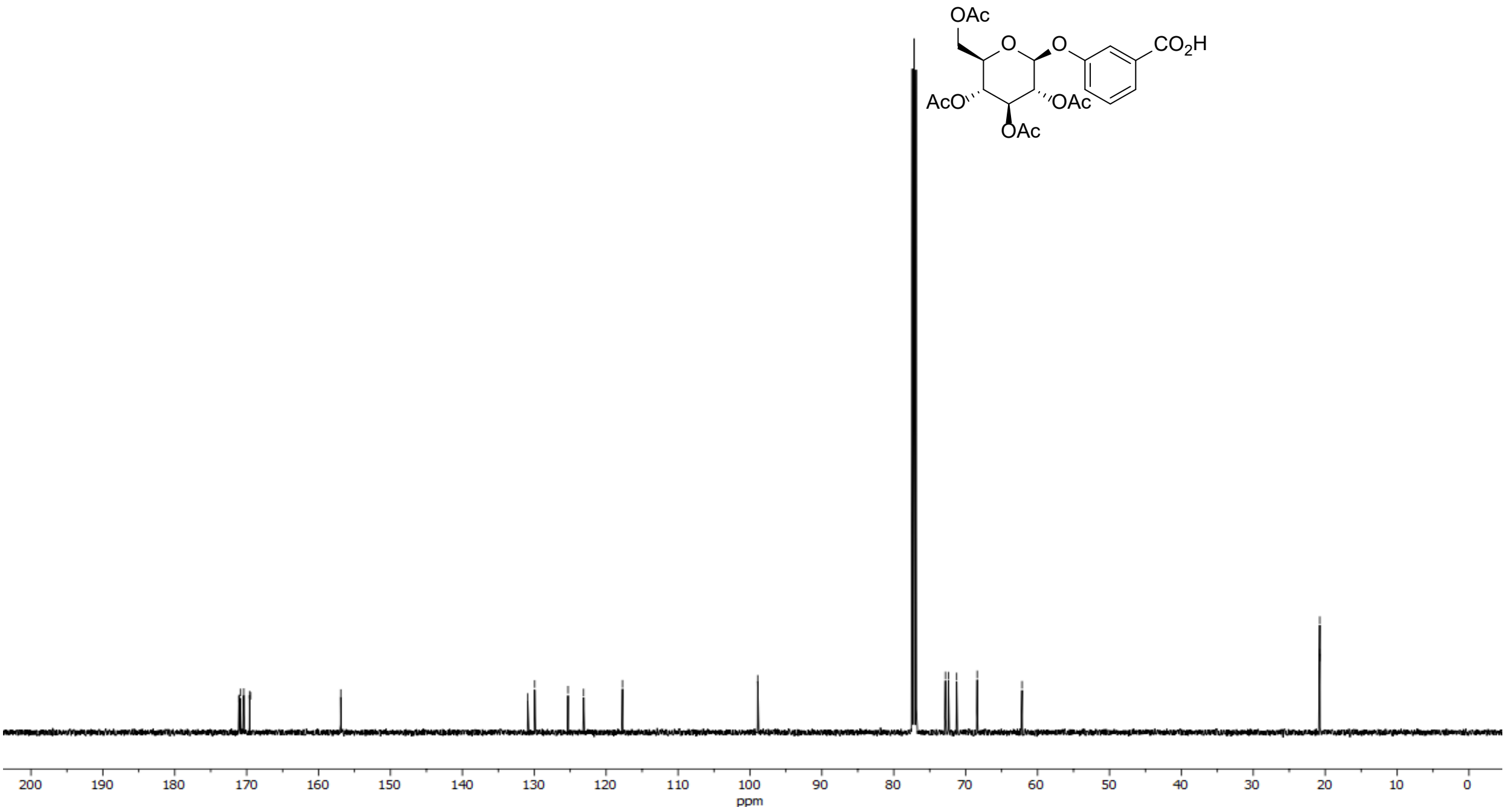
${ }^{1} \mathrm{H}$ NMR of (+)-menthol derivative S4

$\mathrm{CDCl}_{3}, 298 \mathrm{~K}$

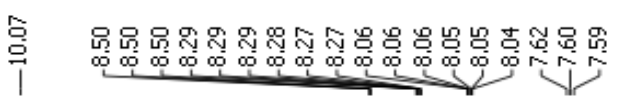

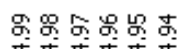

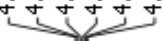
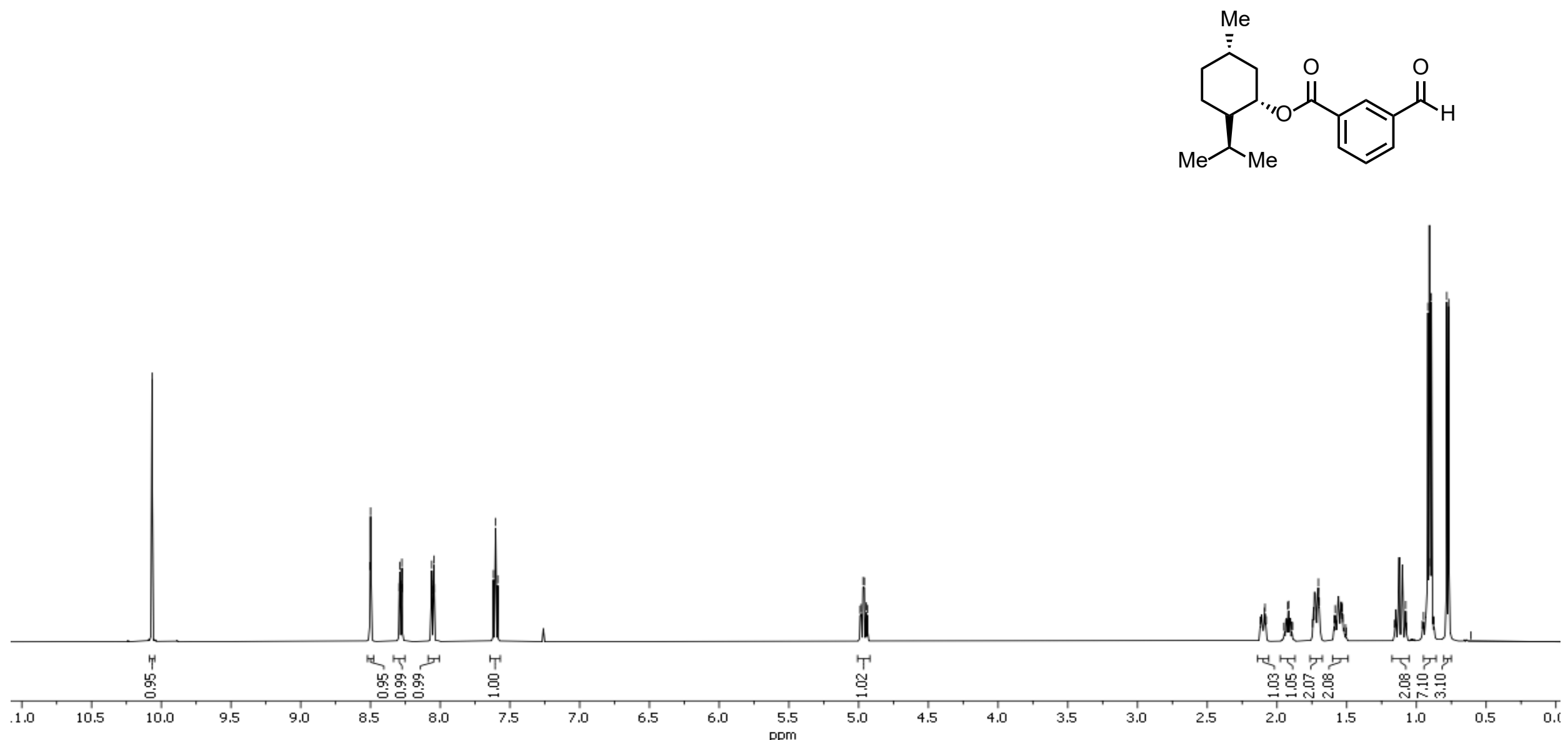
${ }^{13} \mathrm{C}$ NMR of (+)-menthol derivative S4

$\mathrm{CDCl}_{3}, 298 \mathrm{~K}$
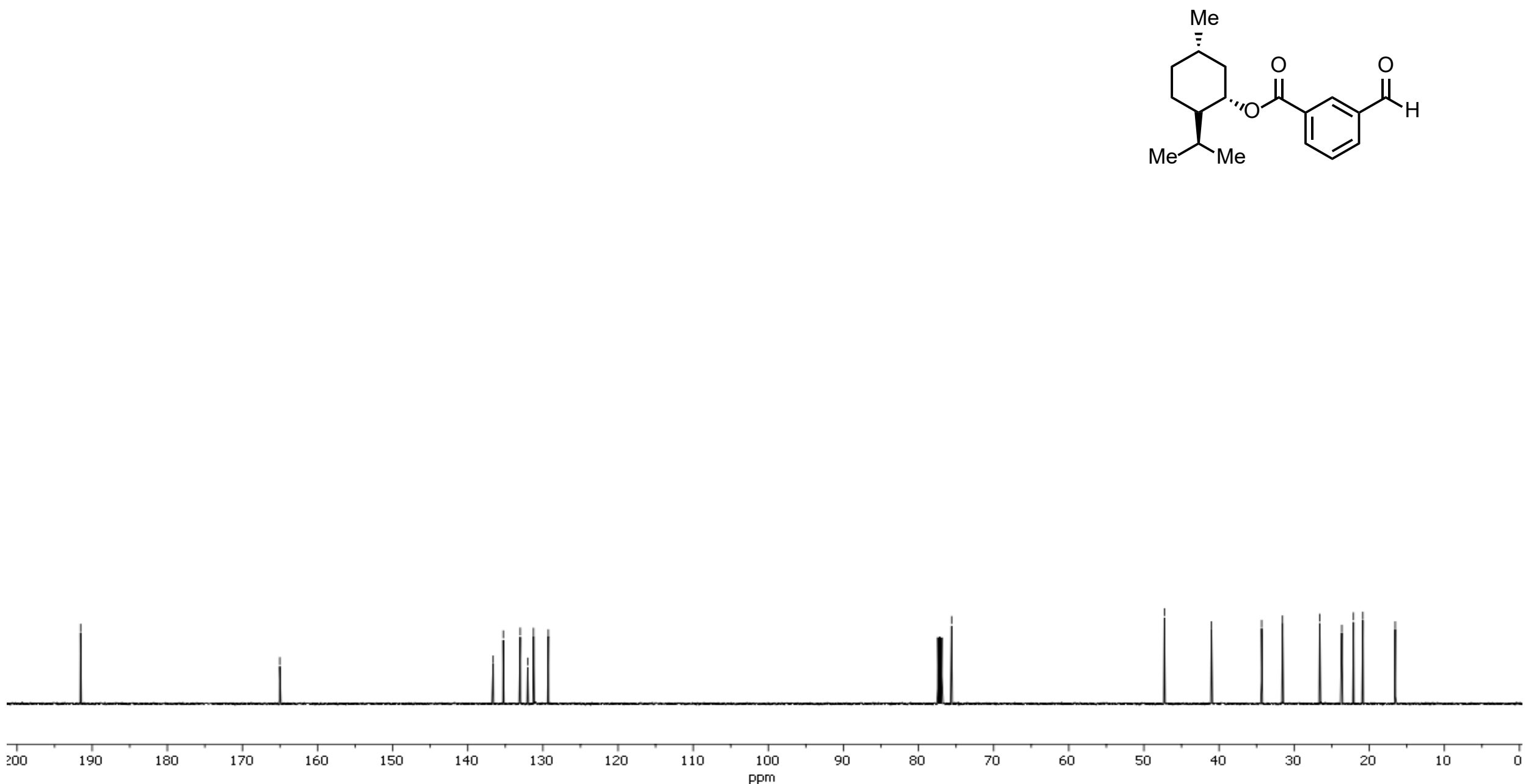
${ }^{1} \mathrm{H}$ NMR of (+)-menthol derivative S5

$\mathrm{CDCl}_{3}, 298 \mathrm{~K}$<smiles>CC(C)[C@H]1CC[C@@H](C)C[C@H]1OC(=O)c1cccc(C(=O)O)c1</smiles>

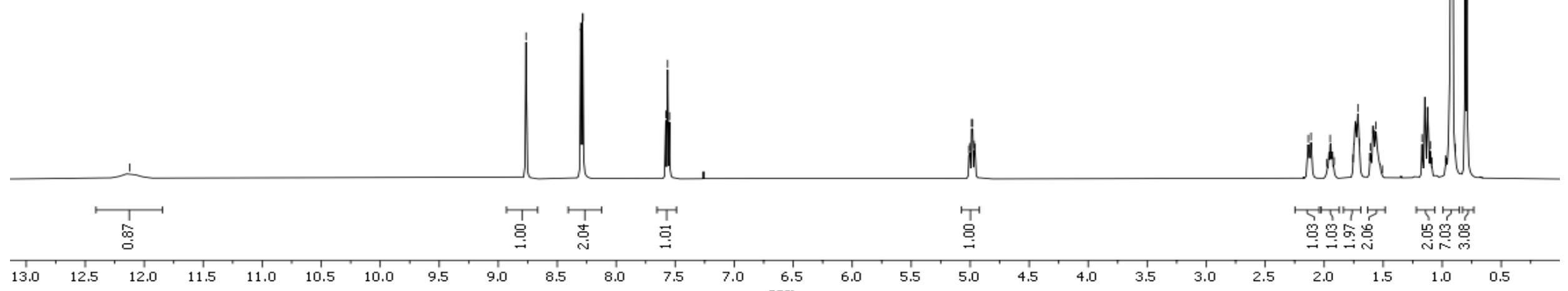


${ }^{13} \mathrm{C}$ NMR of (+)-menthol derivative S5

$\mathrm{CDCl}_{3}, 298 \mathrm{~K}$

| 盗
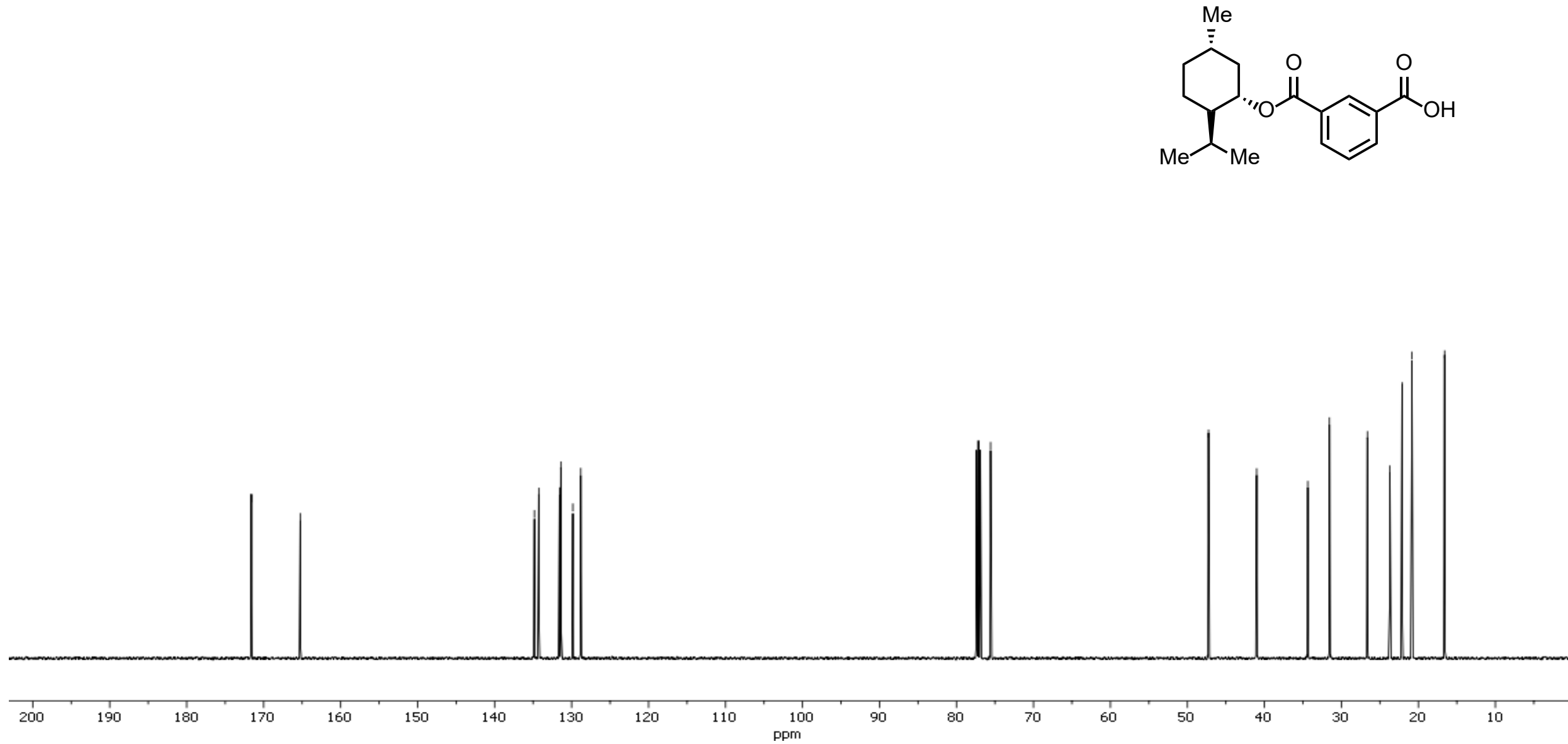
${ }^{1} \mathrm{H}$ NMR of $\mathrm{N}$-succinimidyl 4-formylbenzoate (S6)

$\mathrm{CDCl}_{3}, 298 \mathrm{~K}$
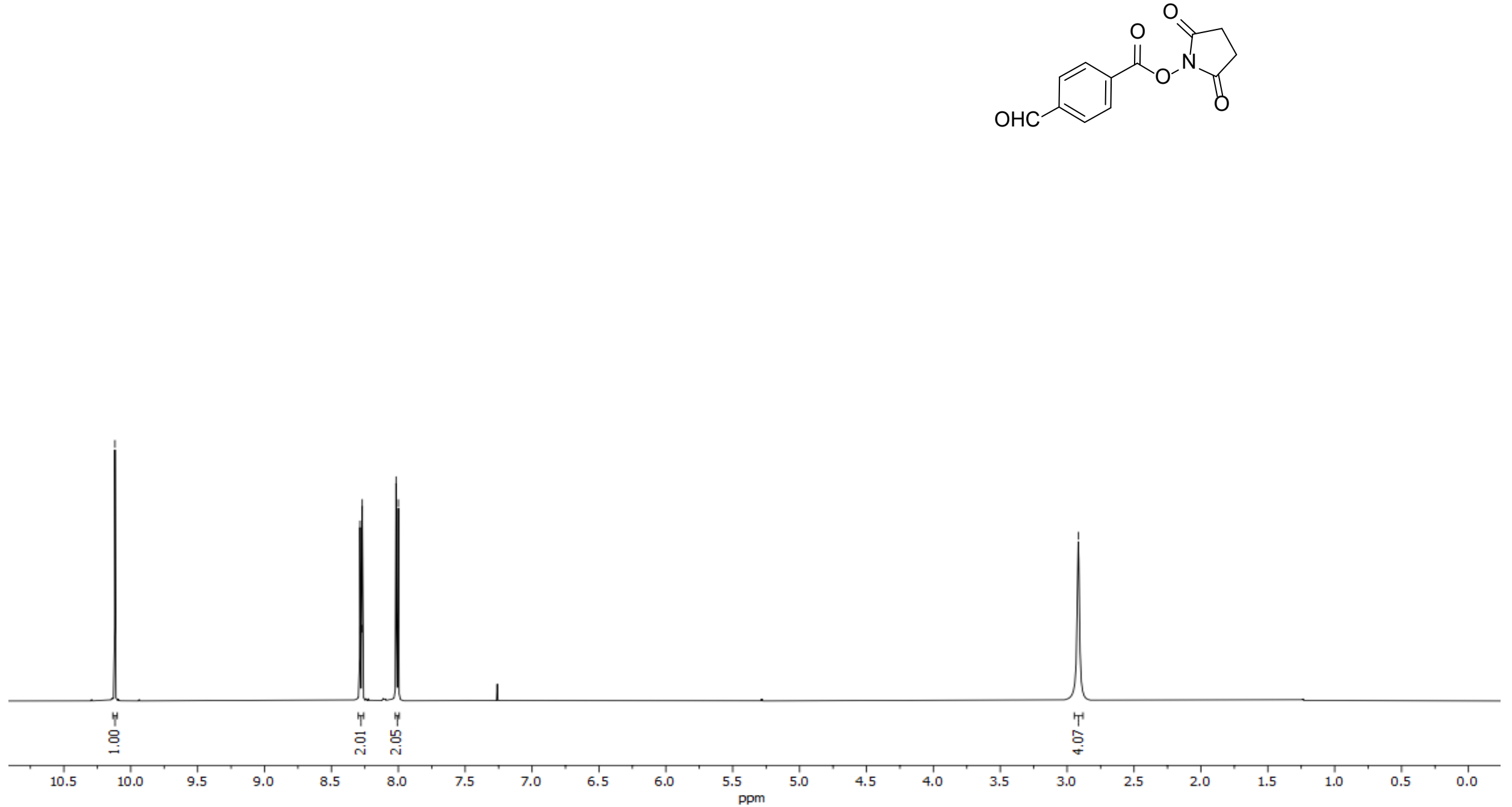
${ }^{13} \mathrm{C}$ NMR of $\mathrm{N}$-succinimidyl 4-formylbenzoate (S6)

$\mathrm{CDCl}_{3}, 298 \mathrm{~K}$

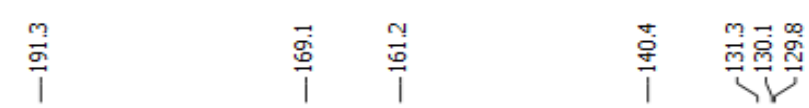
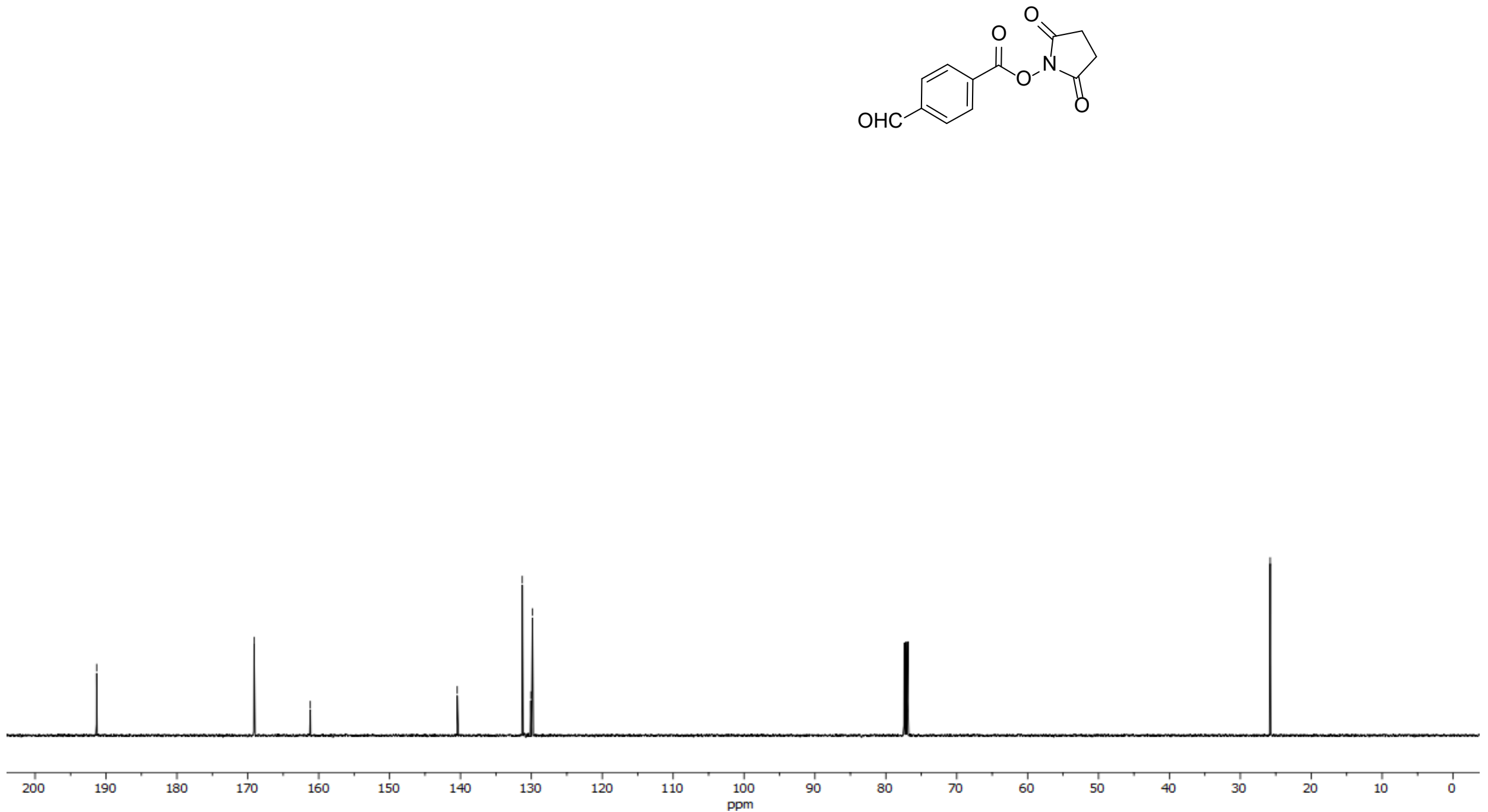
${ }^{1} \mathrm{H}$ NMR of $\mathrm{N}$-succinimidyl 4-carboxybenzoate (S7)

$\left(\mathrm{CD}_{3}\right)_{2} \mathrm{SO}, 298 \mathrm{~K}$
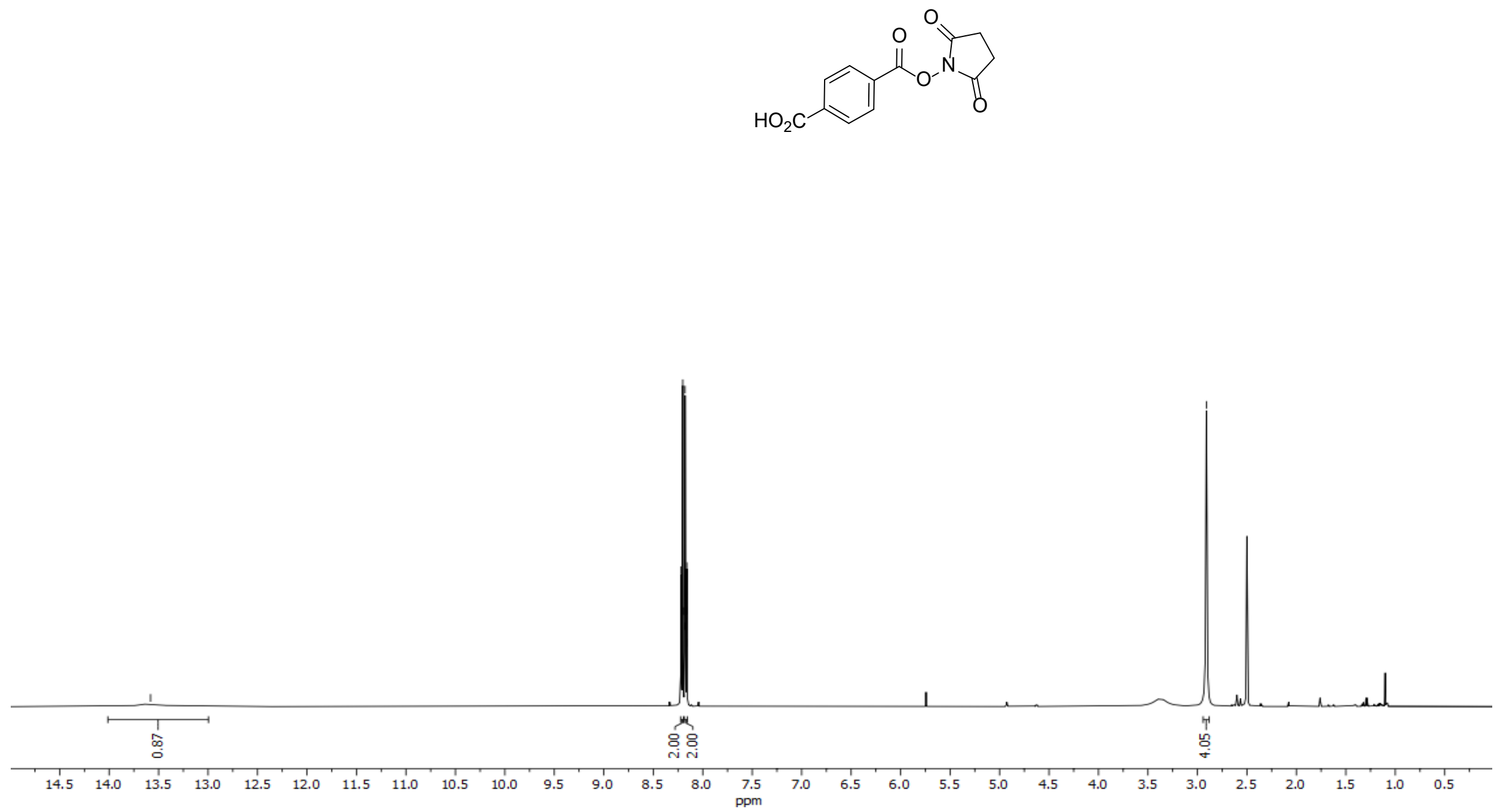
${ }^{13} \mathrm{C}$ NMR of $\mathrm{N}$-succinimidyl 4-carboxybenzoate (S7)

$\left(\mathrm{CD}_{3}\right)_{2} \mathrm{SO}, 298 \mathrm{~K}$
广
|
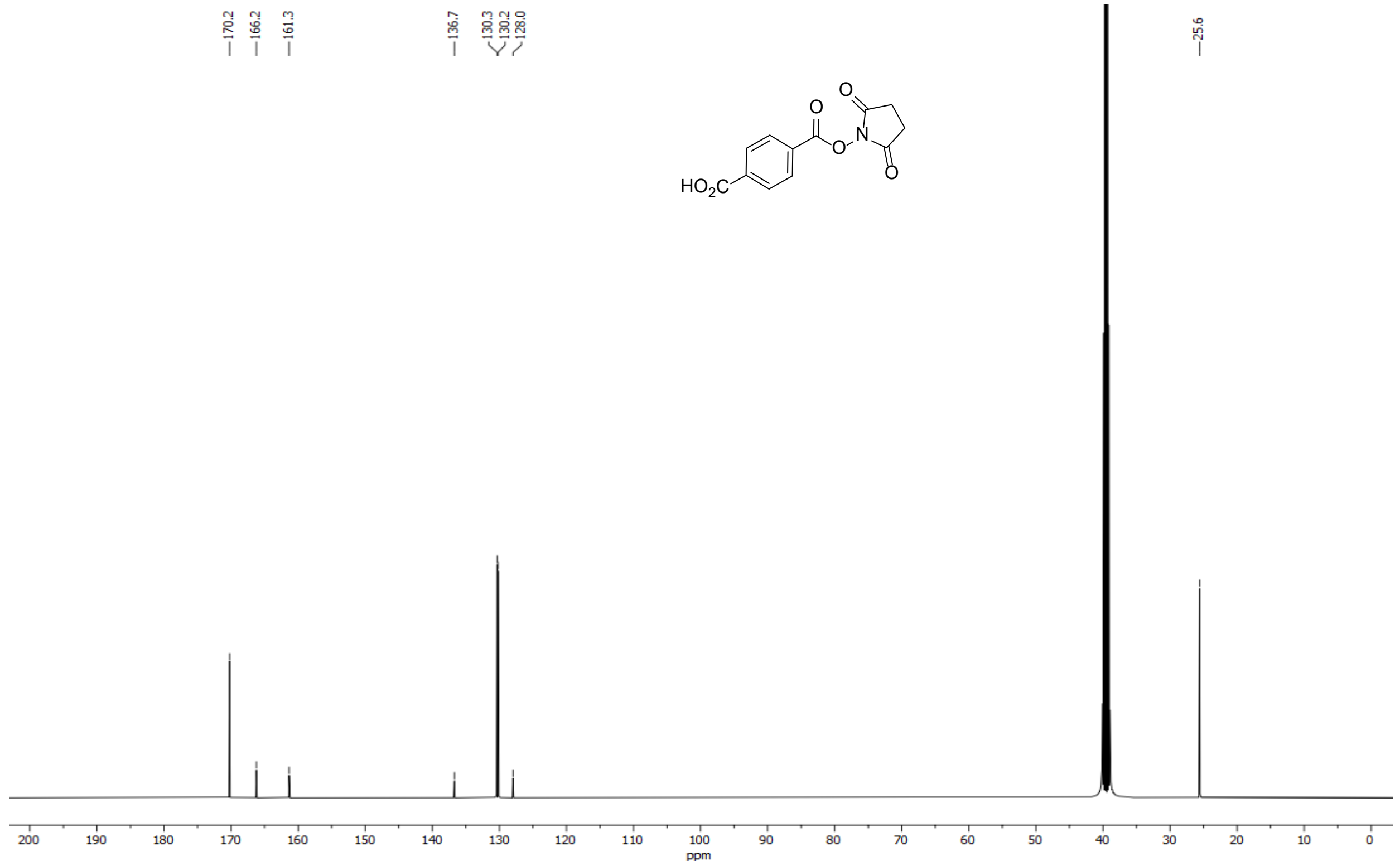


\section{${ }^{1} \mathrm{H}$ NMR of fenofibrate derivative S8}

$\mathrm{CDCl}_{3}, 298 \mathrm{~K}$
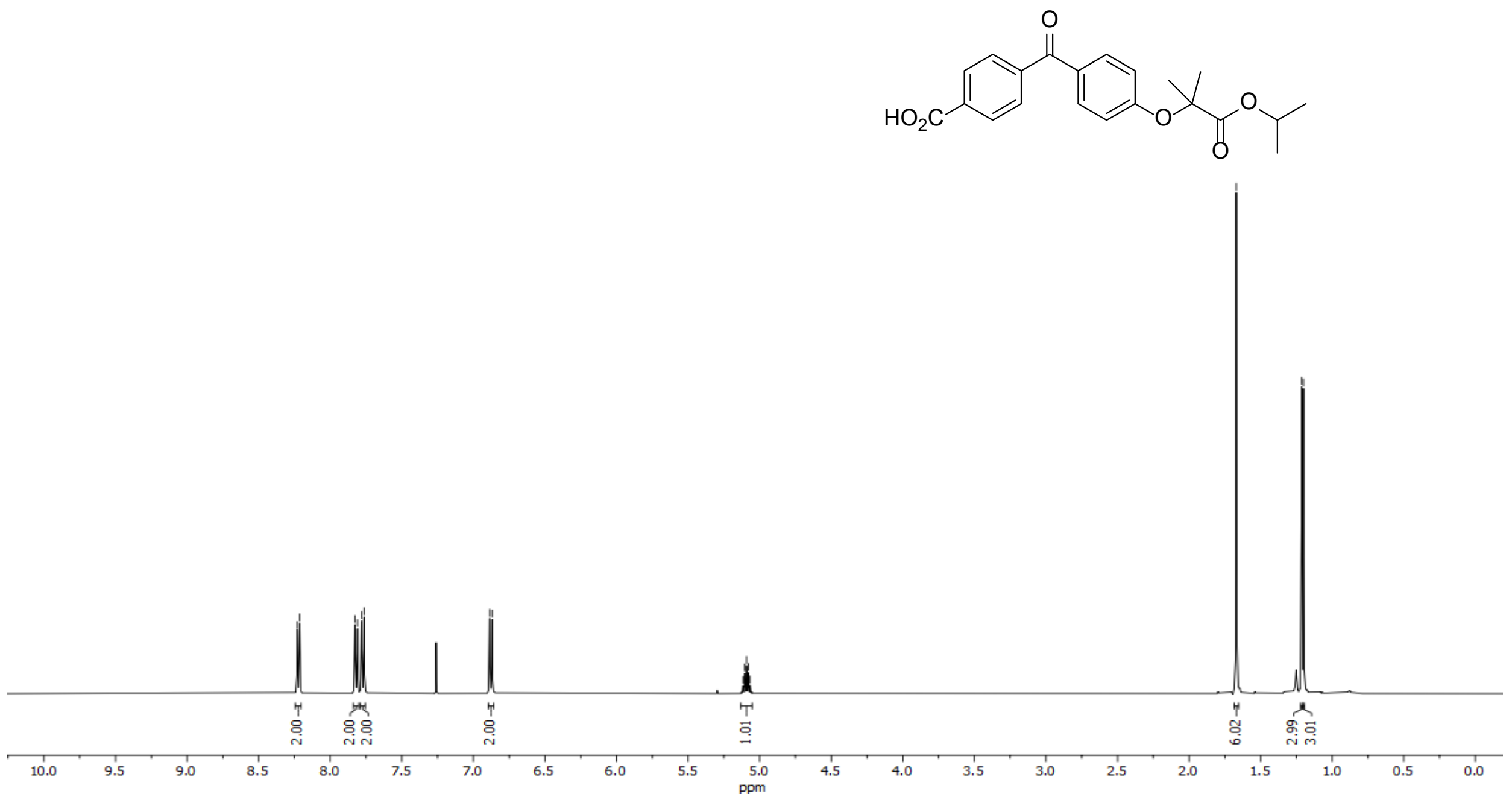


\section{${ }^{13} \mathrm{C}$ NMR of fenofibrate derivative S8}

$\mathrm{CDCl}_{3}, 298 \mathrm{~K}$

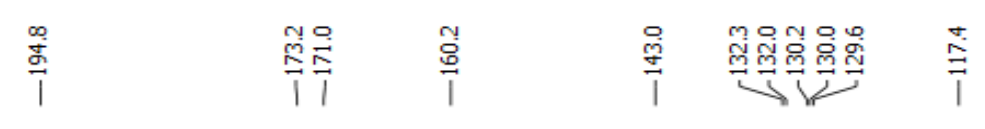

$\stackrel{\circ}{\stackrel{\circ}{\sigma}} \stackrel{\circ}{i}$

瓷
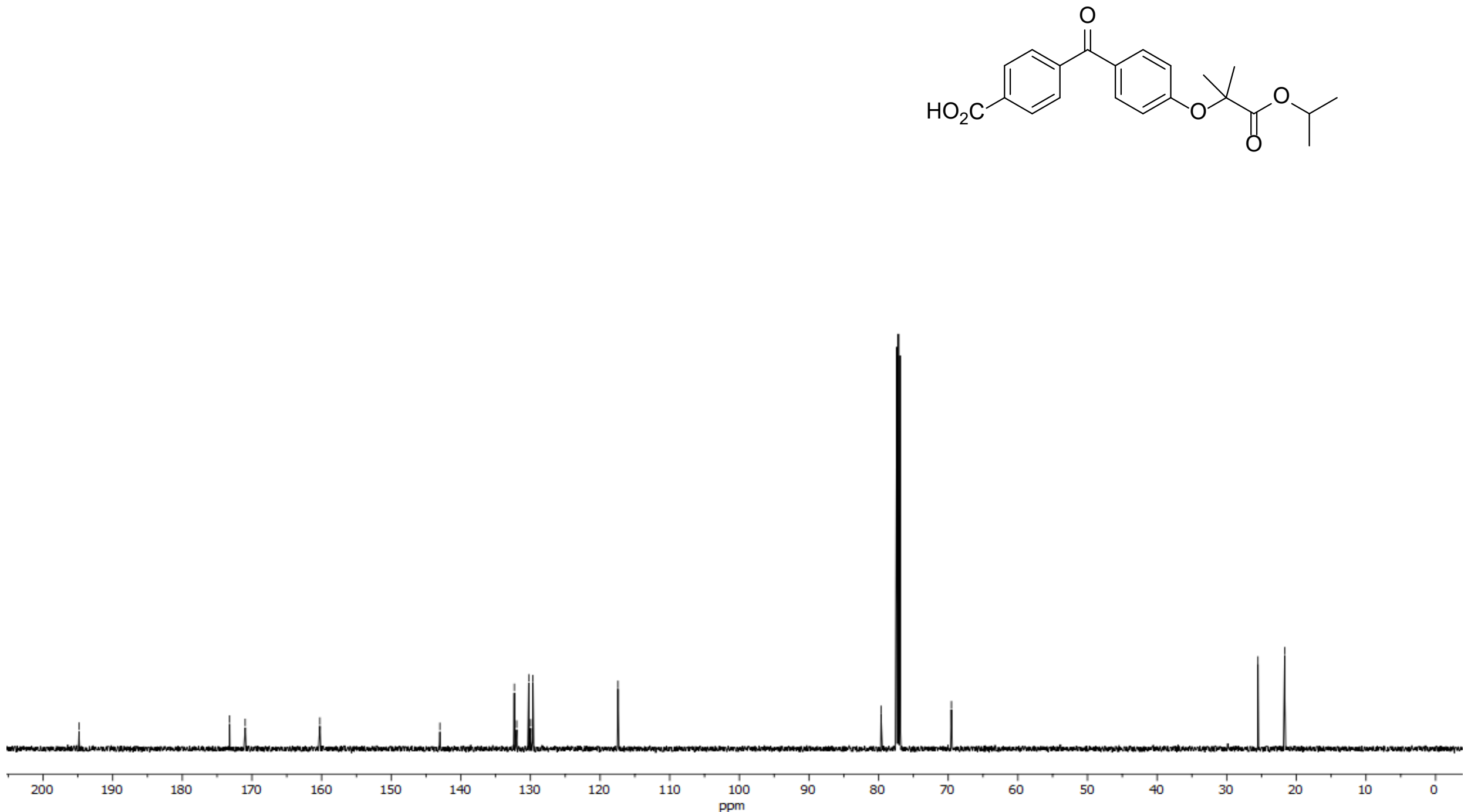
${ }^{1} \mathrm{H}$ NMR of 4-fluorobenzoic acid derived oxime ester 33

$\mathrm{CD}_{2} \mathrm{Cl}_{2}, 298 \mathrm{~K}$

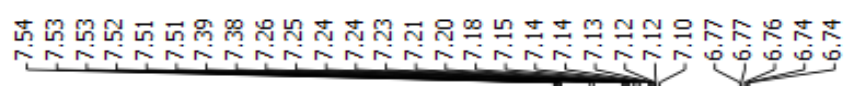

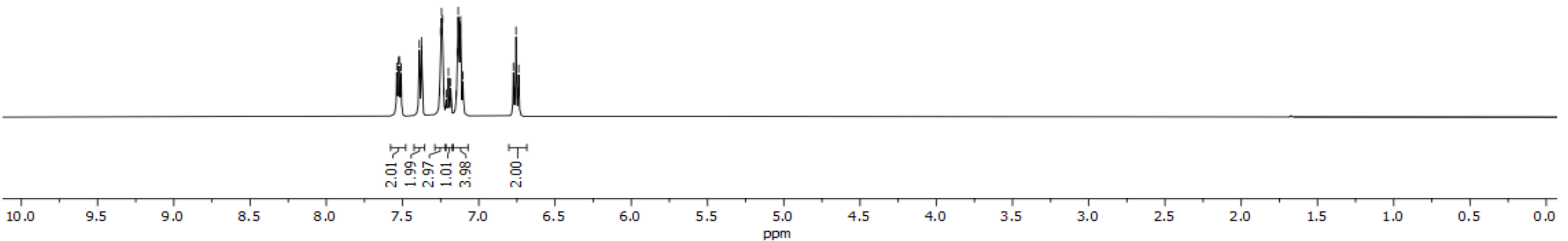


${ }^{13} \mathrm{C}$ NMR of 4-fluorobenzoic acid derived oxime ester 33

$\mathrm{CD}_{2} \mathrm{Cl}_{2}, 298 \mathrm{~K}$

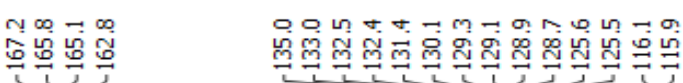

$$
\begin{aligned}
& \text { 각 }
\end{aligned}
$$

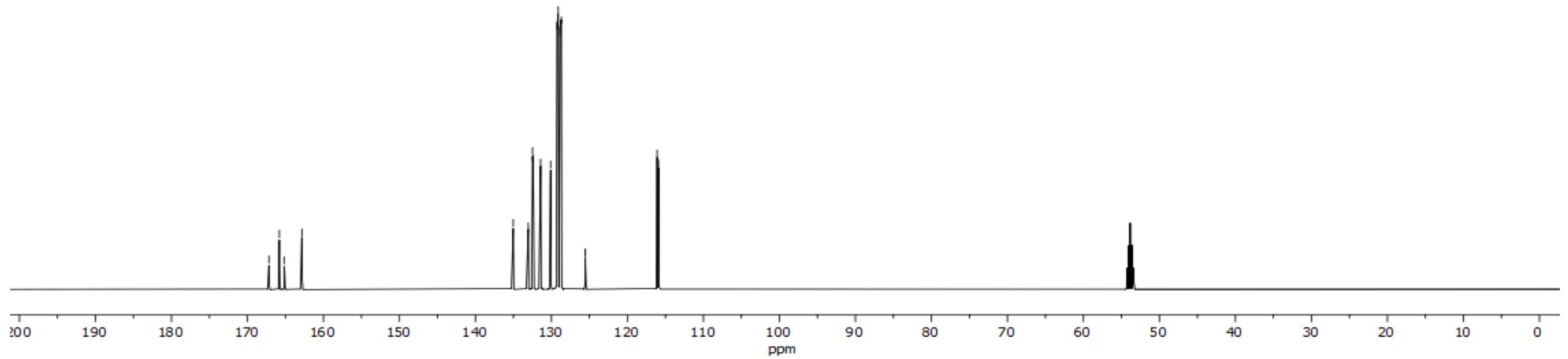


${ }^{19} \mathrm{~F}$ NMR of 4-fluorobenzoic acid derived oxime ester 33

$\mathrm{CD}_{2} \mathrm{Cl}_{2}, 298 \mathrm{~K}$
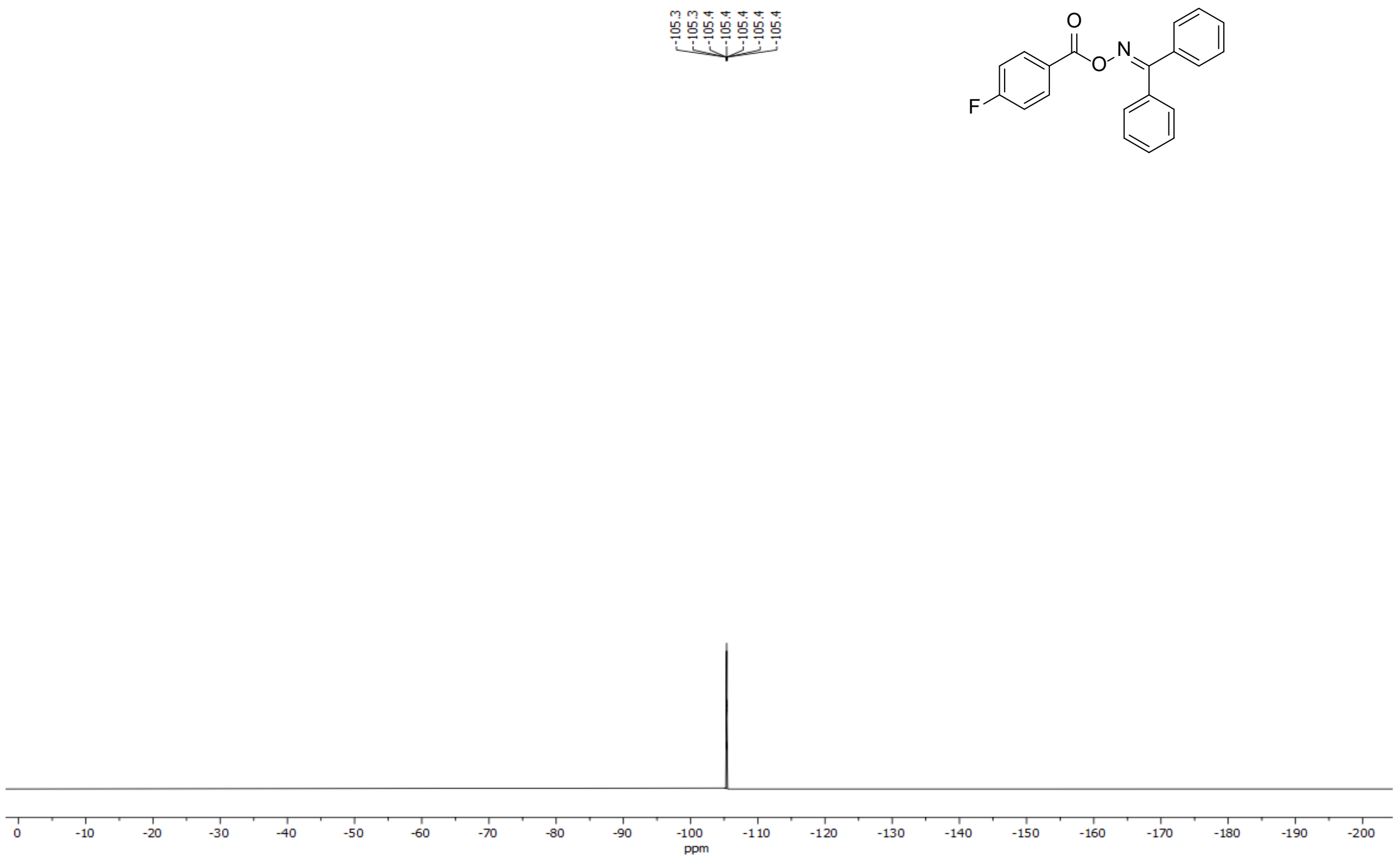
${ }^{1} \mathrm{H}$ NMR of phenyl 3-methoxybenzoate (10a)

$\mathrm{CDCl}_{3}, 298 \mathrm{~K}$

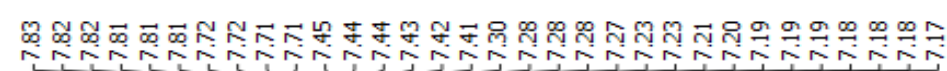

L

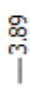
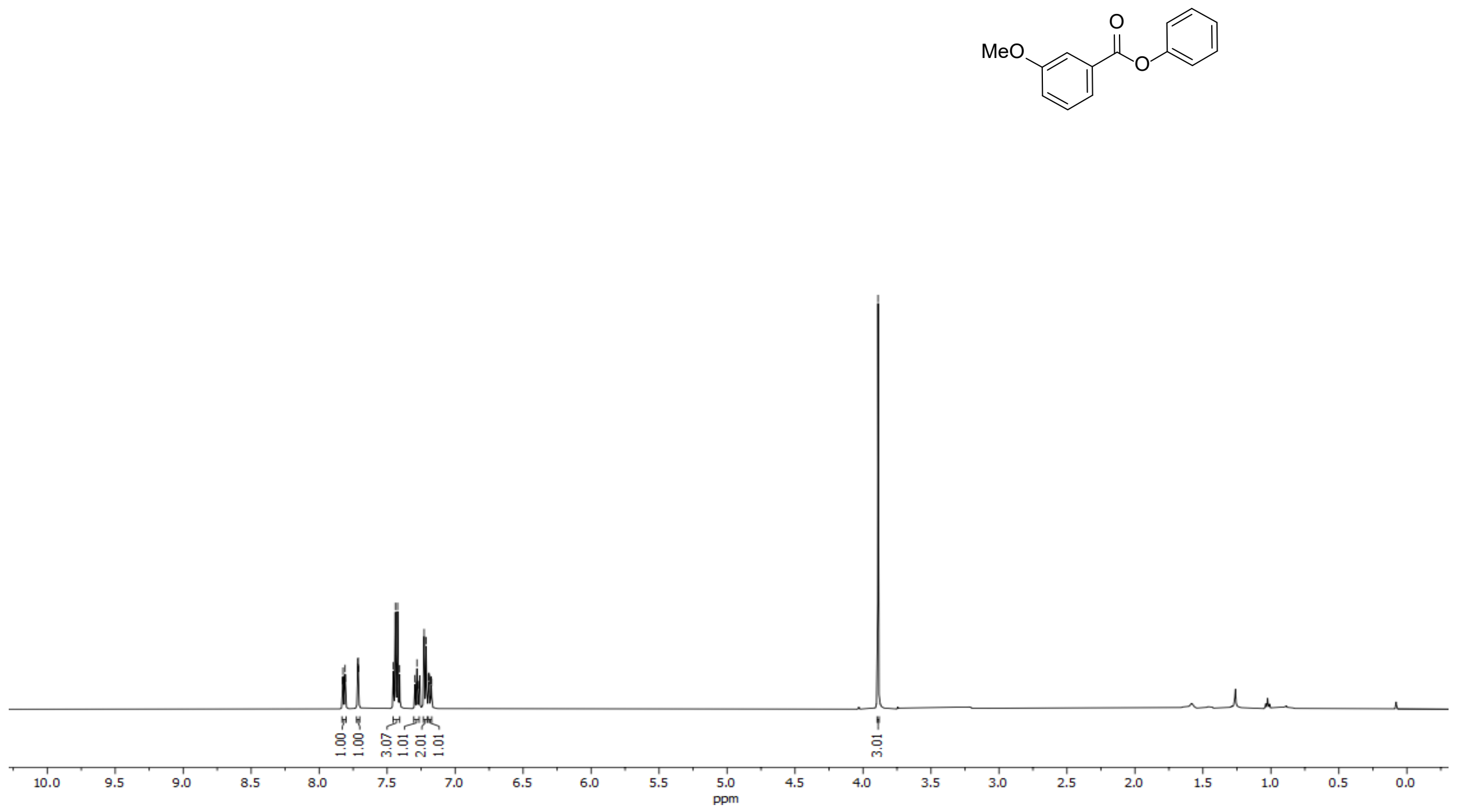
${ }^{13} \mathrm{C}$ NMR of phenyl 3-methoxybenzoate (10a)

$\mathrm{CDCl}_{3}, 298 \mathrm{~K}$

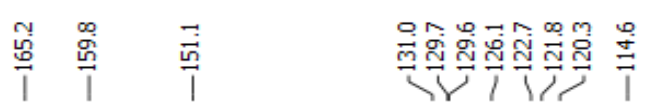

岕
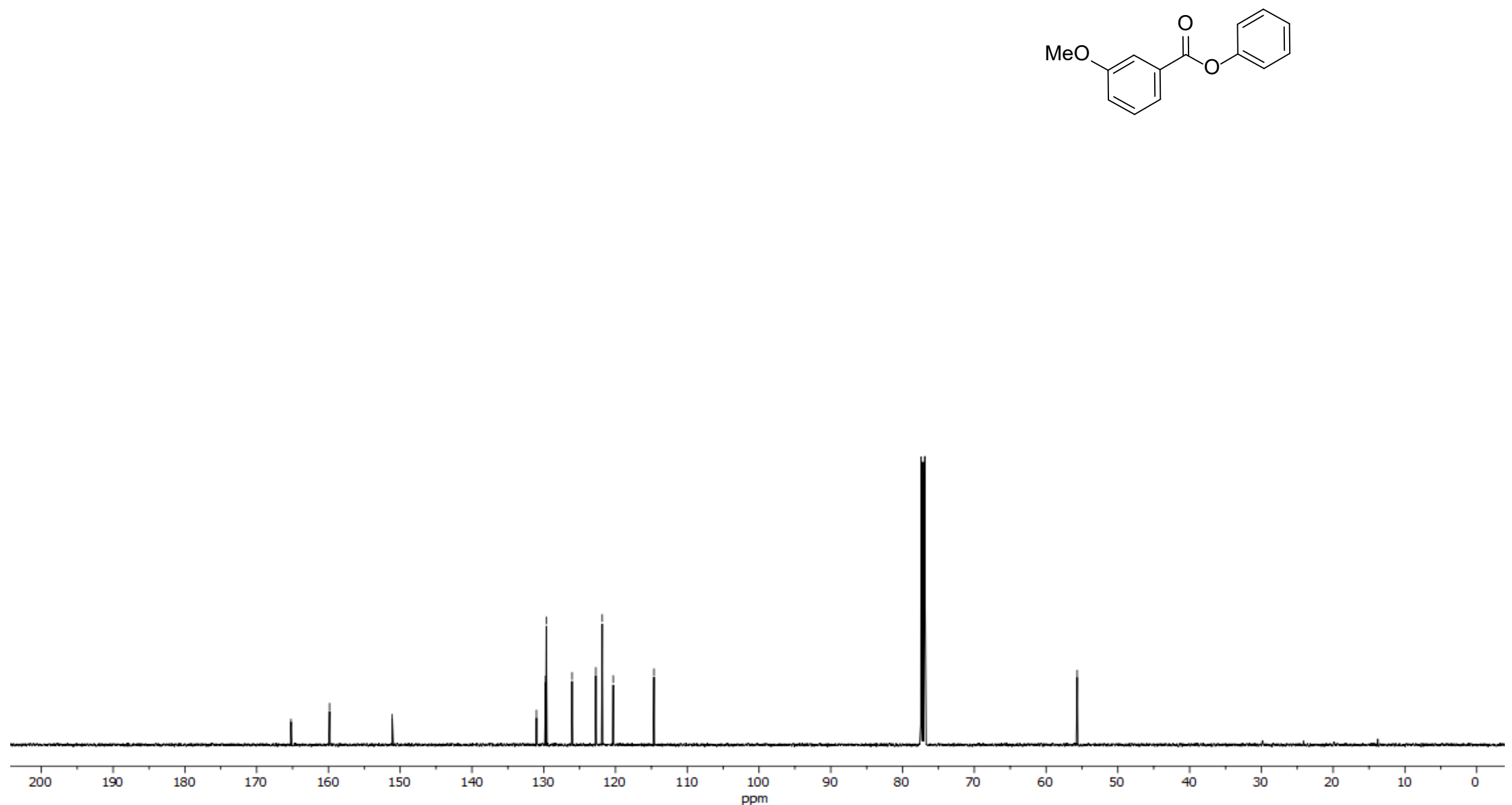
${ }^{1} \mathrm{H}$ NMR of 3-methoxy-1,1'-biphenyl (10b)

$\mathrm{CDCl}_{3}, 298 \mathrm{~K}$

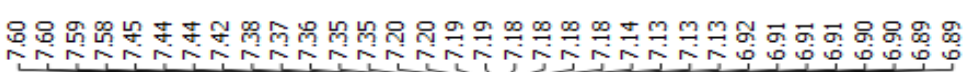

$\underset{\substack{\infty \\ \prod}}{\stackrel{\infty}{j}}$
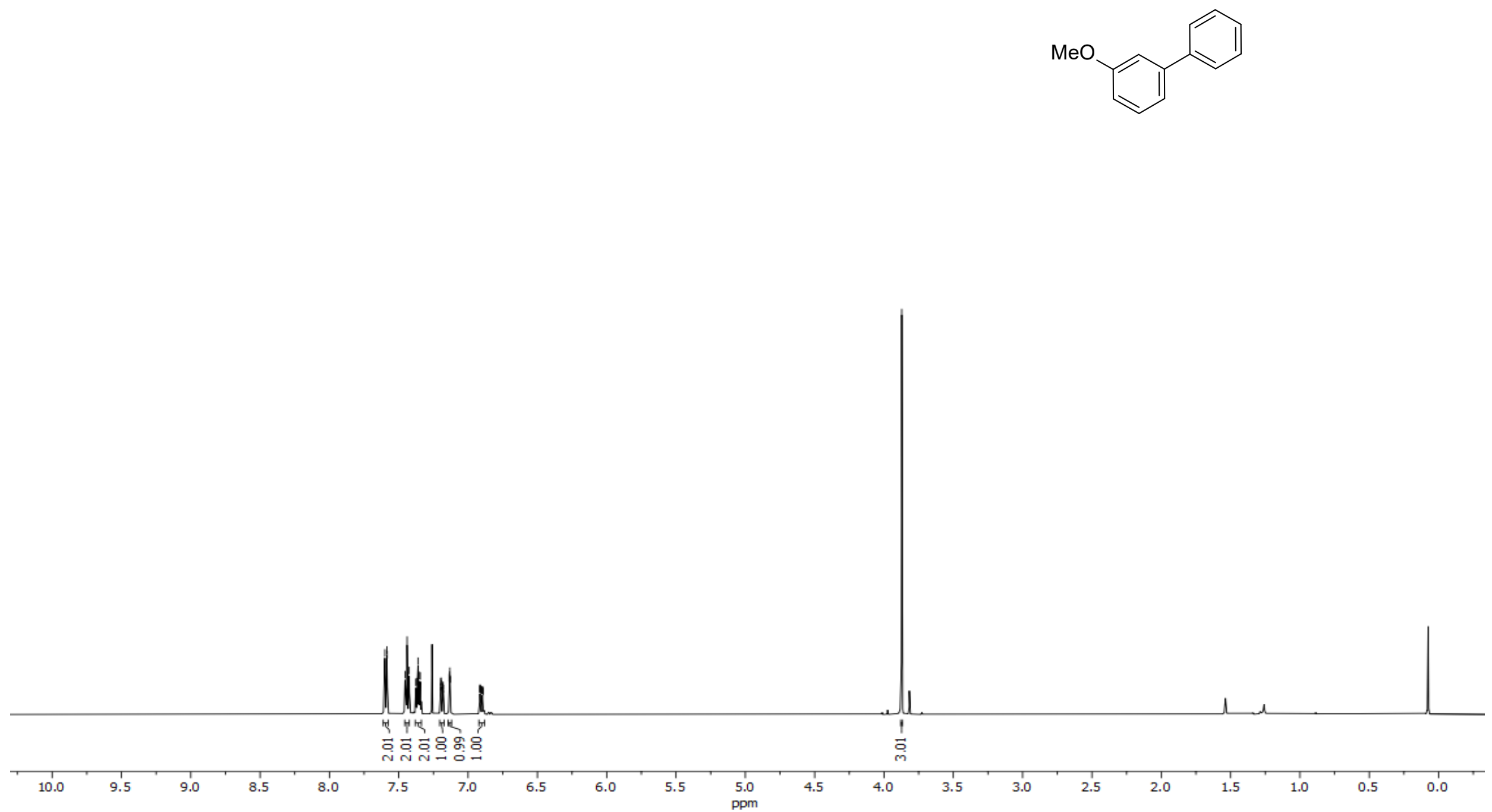
${ }^{13} \mathrm{C}$ NMR of 3-methoxy-1,1'-biphenyl (10b)

$\mathrm{CDCl}_{3}, 298 \mathrm{~K}$
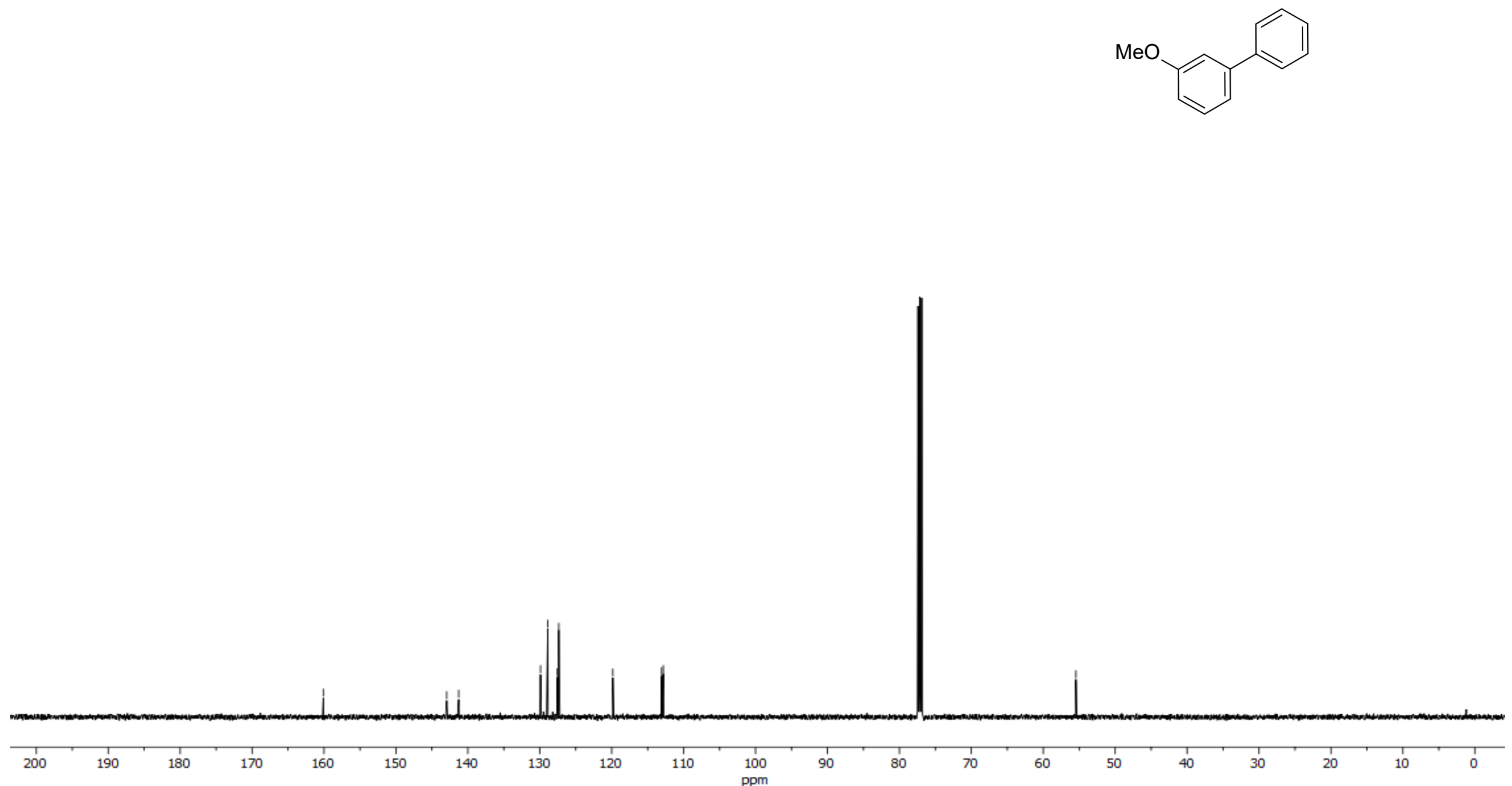
${ }^{1} \mathrm{H}$ NMR of $6 H$-benzo[c]chromen-6-one (32)

$\mathrm{CDCl}_{3}, 298 \mathrm{~K}$

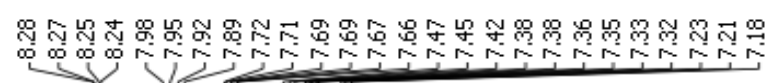
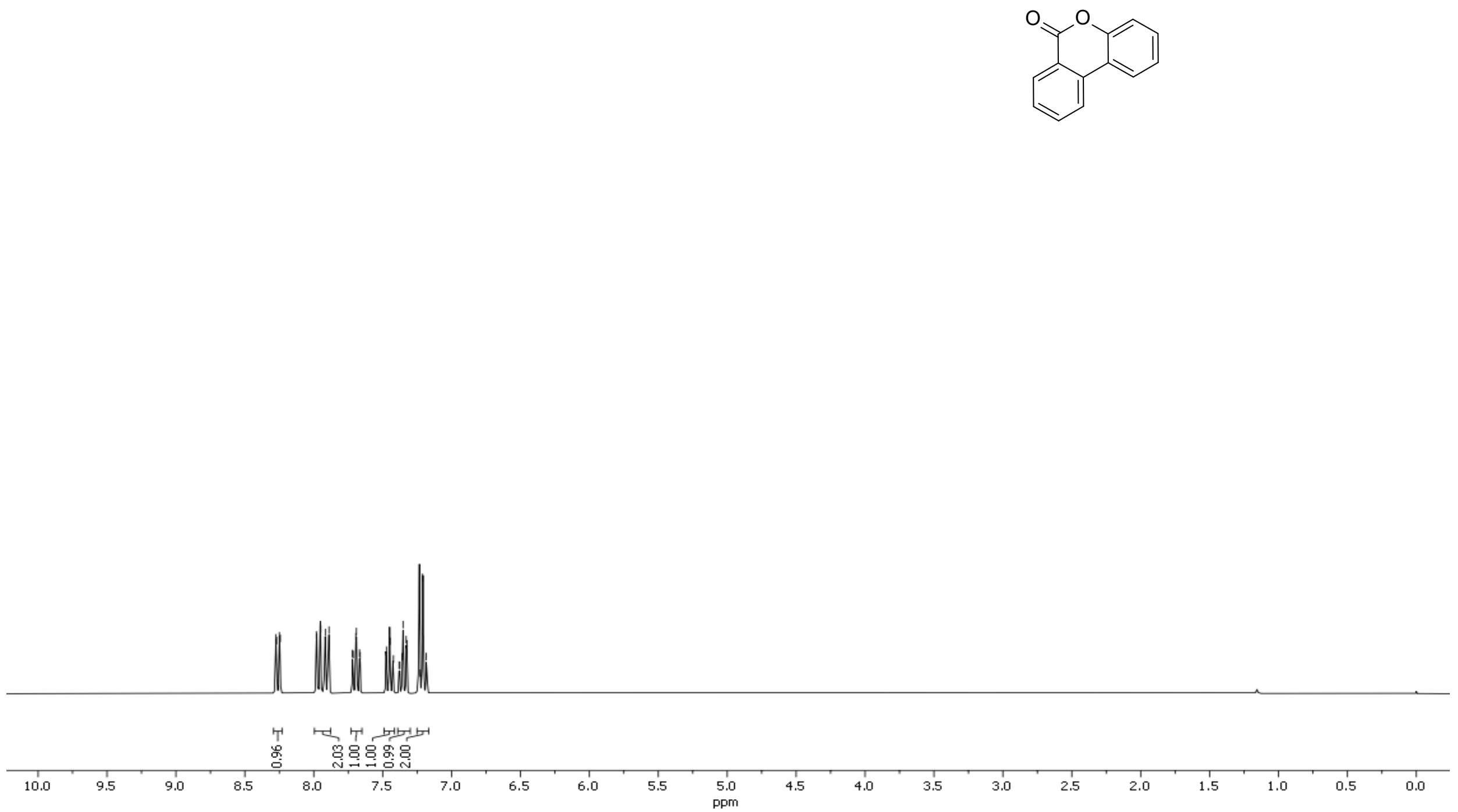
${ }^{13} \mathrm{C}$ NMR of $6 H$-benzo[c]chromen-6-one (32)

$\mathrm{CDCl}_{3}, 298 \mathrm{~K}$

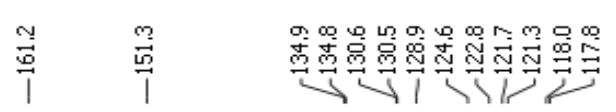
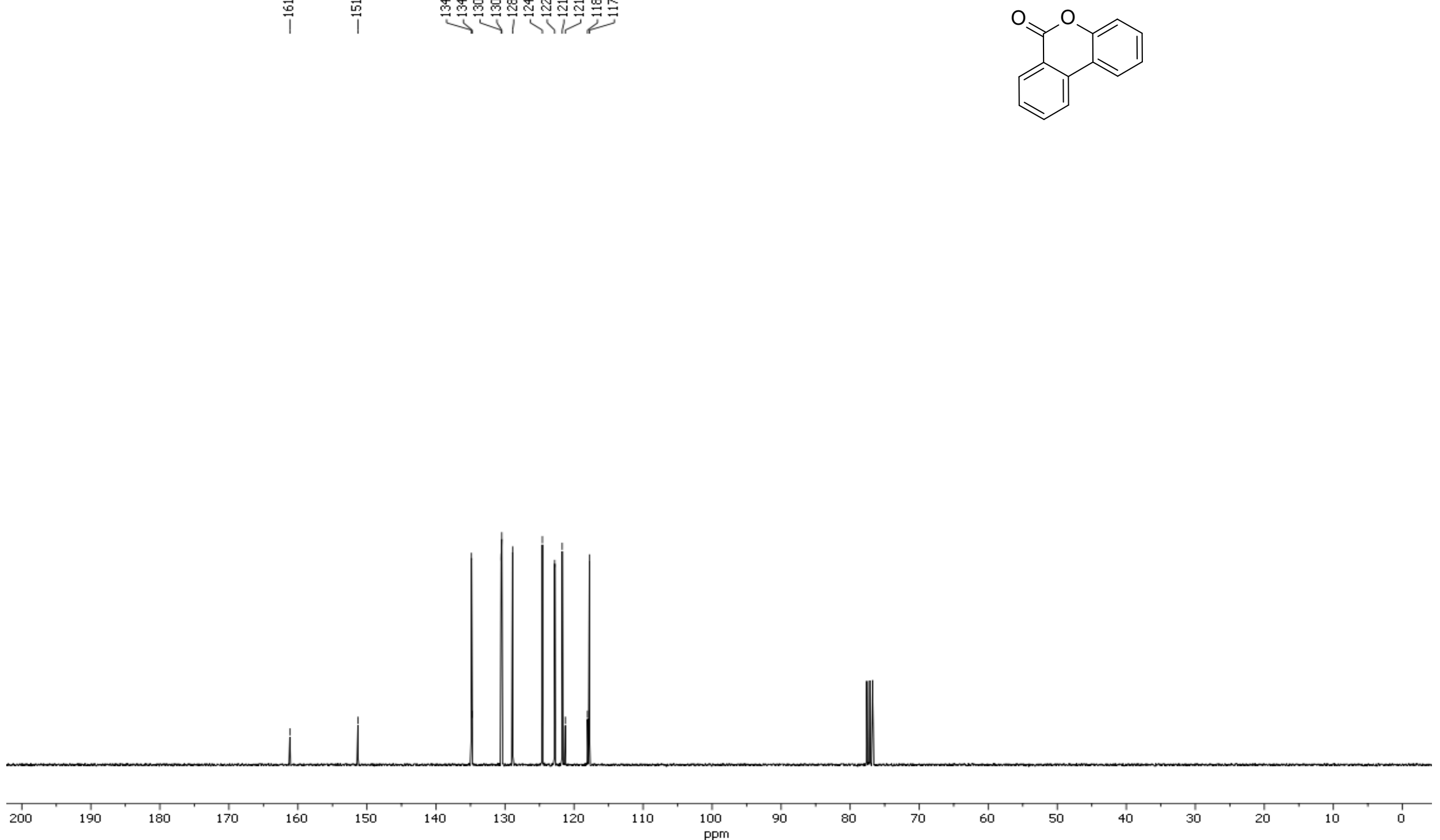